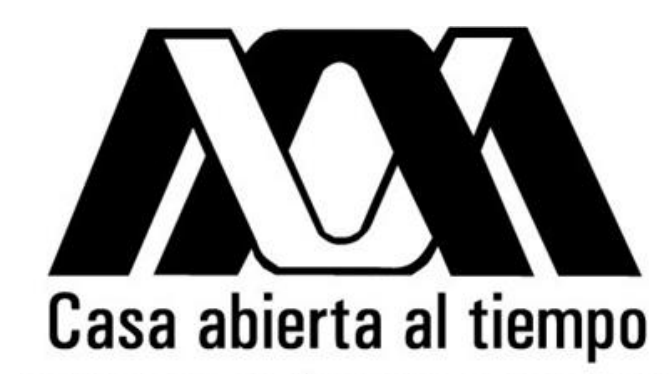

UNIVERSIDAD AUTÓNOMA METROPOLITANA

IZTAPALAPA

\title{
“OBTENCIÓN Y CARACTERIZACIÓN DE NANOFIBRILLAS DE QUITINA EXTRAÍDA POR MÉTODOS BIOLÓGICOS Y SU DESACETILACIÓN A QUITOSANO”
}

\author{
TESIS \\ QUE PARA OBTENER EL GRADO DE \\ DOCTOR EN BIOTECNOLOGÍA \\ PRESENTA \\ M. EN BIOT. RUT ARANDAY GARCIA
}

DIRECTORA:

DRA. CONCEPCIÓN KEIKO SHIRAI MATSUMOTO

Universidad Autónoma Metropolitana, Departamento de Biotecnología, Laboratorio de Biopolímeros y Planta Piloto de Procesamiento de Desperdicios Orgánicos

ASESORES:

Dra. ANGÉLICA ROMÁN GUERRERO

Universidad Autónoma Metropolitana, Departamento de Biotecnología

Dr. SHINSUKE IFUKU

Graduate School of Engineering, Department of Chemistry and Biotechnology, Tottori University, Japan 
“El Doctorado en Biotecnología de la Universidad Autónoma Metropolitana está incluido en el Programa Nacional de Posgrados de Calidad (PNPC) del CONACYT, con la referencia 001466".

Esta tesis se realizó en el Laboratorio de Biopolímeros (S-157) y en la Planta Piloto de Procesamiento de Desperdicios Orgánicos (PP10) del Departamento de Biotecnología de la División de Ciencias Biológicas y de la Salud, Universidad Autónoma Metropolitana Unidad Iztapalapa, bajo la dirección de la Dra. Concepción Keiko Shirai Matsumoto. El trabajo experimental se llevó a cabo con financiamiento de CONACyT (No. 237292) y FINNOVA/CONACYT No. 224962.

La obtención de nanofibrillas de quitina y elaboración de películas de nanofibrillas se llevó a cabo en el Departamento de Química y Biotecnología de la Universidad de Tottori, bajo la asesoría del Dr. Shinsuke Ifuku gracias a la beca mixta asignada por CONACYT a Rut Aranday García para la realización de dicha estancia. 
El H. Jurado designado por la División de Ciencias Biológicas y de la Salud de la Universidad Autónoma Metropolitana Unidad Iztapalapa aprobó la tesis:

\title{
“OBTENCIÓN Y CARACTERIZACIÓN DE NANOFIBRILLAS DE QUITINA EXTRAÍDA POR MÉTODOS BIOLÓGICOS Y SU DESACETILACIÓN A QUITOSANO"
}

Que presenta:

\author{
M. en Biot. Rut Aranday García
}

Comité tutoral:

Directora de tesis:

Dra. Concepción Keiko Shirai Matsumoto.

Universidad Autónoma Metropolitana Unidad Iztapalapa, Departamento de Biotecnología. Laboratorio de Biopolímeros Planta Piloto de Procesamiento de Desperdicios Orgánicos.

Asesores de tesis:

Dra. Angélica Román Guerrero

Universidad Autónoma Metropolitana Unidad Iztapalapa, Departamento de Ciencias de la Salud, Posgrado en Biotecnología.

Dr. Shinsuke Ifuku

Graduate School of Engineering, Department of Chemistry and Biotechnology, Tottori University, Japan.

H. Jurado:

Presidente: Dra. Phaedra Suriel Silva Bermúdez

Secretario: Dra. Angélica Román Guerrero

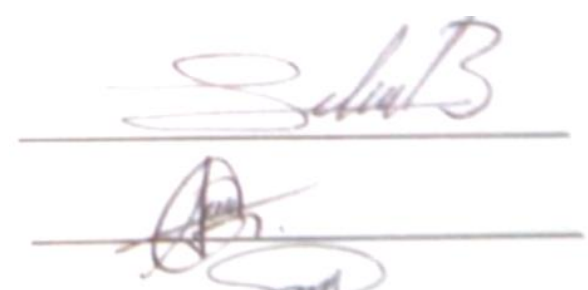

Vocal: $\quad$ Dr. Gabriel Vigueras Ramírez

Vocal: Dra. Gabriela Mariana Rodríguez Serrano 


\section{AGRADECIMIENTOS}

A la Dra. Keiko Shirai Matsumoto por la oportunidad de trabajar con ella en el laboratorio de biopolímeros, por su confianza, ayuda y guía en cada etapa del posgrado; así como su apoyo para la realización de una estancia en el extranjero.

A la Dra. Angélica Román Guerrero, por su ayuda y cooperación a lo largo del posgrado.

A la Universidad Autónoma Metropolitana Iztapalapa por brindarme la oportunidad de formarme como profesional en Biotecnología.

A la Universidad de Tottori y la División de Asuntos Internacionales de la Universidad, por toda el apoyo y atención brindados.

Al Consejo Nacional de Ciencia y Tecnología (CONACYT) por la beca otorgada para la realización del posgrado, al igual que la beca mixta para la estancia de investigación en el extranjero.

\section{ACKNOWLEDGMENT}

To Dr. Shinsuke Ifuku, for all the help and guidance through procedure for Japanese visa, enrolment on Tottori University and arrangements for my stay in Tottori University International House. Thank you for your guidance and amendments on my investigation project, making my stay pleasant and for allow me to be part of a wonderful work team.

To Dr. Hiroyuki Saimoto, for been so thoughtful and always care for making my stay comfortable.

To all my laboratory companions at Tottori University, for always helping me, teach me so many helpful things, making my stay enjoyable; but above all, for being my friends. 


\section{DEDICATORIAS}

Antes que nada, gracias a Dios por permitirme lograr una meta más y rodearme de gente que siempre estuvo ahí para apoyarme.

A mi esposa Sharai, por toda la ayuda y apoyo, por siempre estar ahí conmigo, por tantas veces que fuiste por mí al salir tarde, por consolarme cada vez que algo salía mal, por ayudarme siempre que te necesité, por alegrarme en cada momento de estrés, por motivarme cuando pensaba que no podía continuar, por compartir el trabajo conmigo. Éste logro es tanto tuyo como mío.

A mis amigos, quiénes siempre mostraron su interés y me apoyaron en todo momento, especialmente a Jenny por tantas horas de plática que fueron la mejor terapia.

A mis compañeros de laboratorio y amigos, Facundo, Monserrat, Lupita, Marco, Carmen, Mariana, Jesús, Zaizy, Ivana, Rosario, Iris, Raquel, Ana y Myreni; por todo lo que aprendí con su ayuda, y porque su presencia mejoró cada experiencia vivida.

A mi familia por todo su apoyo, atención y por siempre creer que era capaz.

A la familia Ibarra Toquero por toda su ayuda y apoyo. 


\section{Contenido}

RESUMEN .

ABSTRACT.

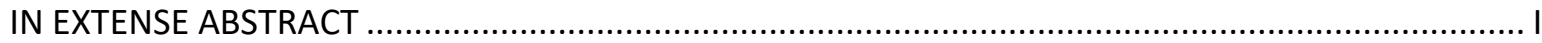

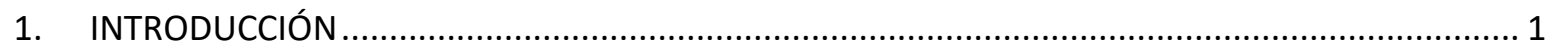

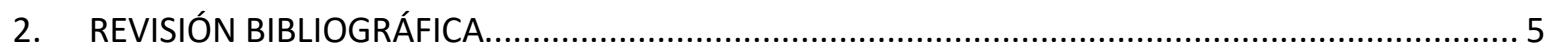

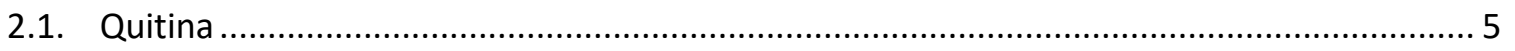

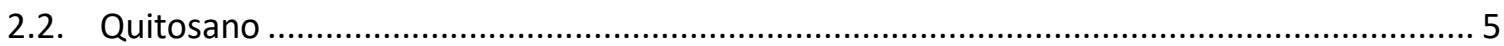

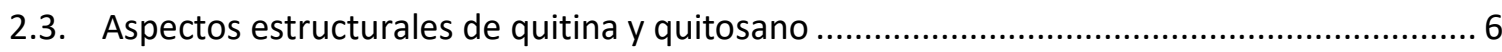

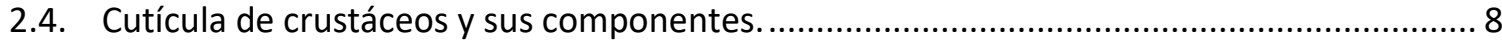

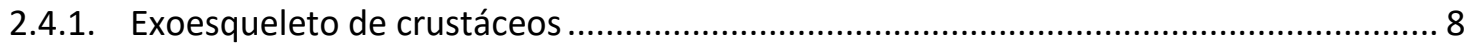

2.4.2. Proteína, minerales y pigmentos en crustáceos....................................................... 9

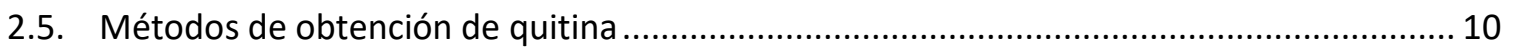

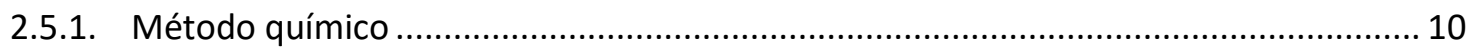

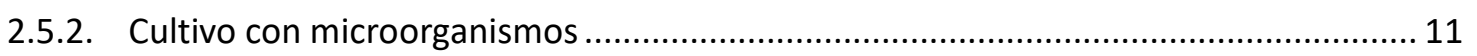

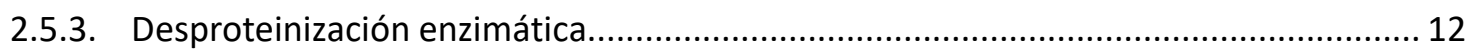

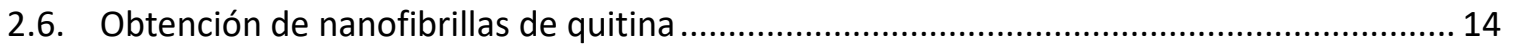

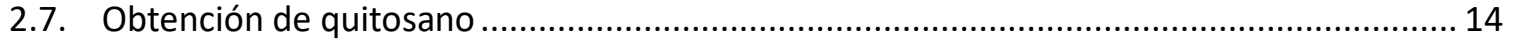

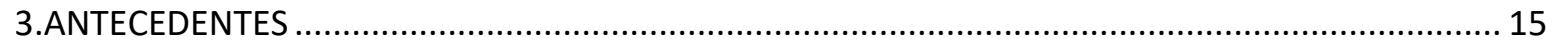

3.1. Cultivo con microorganismos para obtención biológica de quitina.................................. 15

3.2. Desproteinización enzimática para la obtención de quitina ............................................. 17

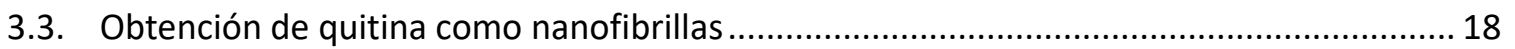

3.4. Obtención de quitosano mediante desacetilación de quitina .......................................... 19

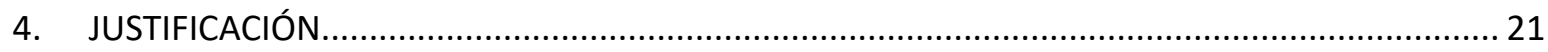

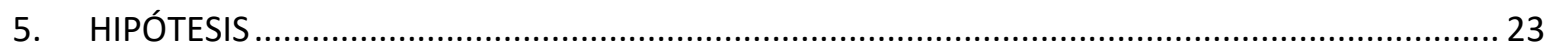

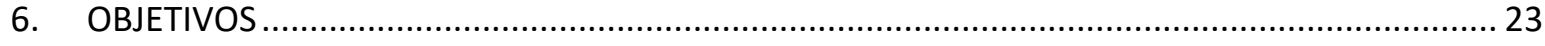

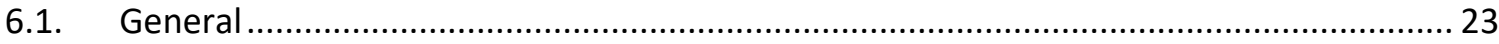

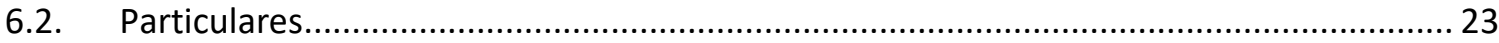

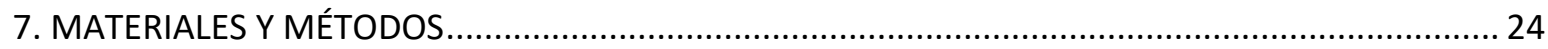

7.1. Primera etapa: Métodos para la obtención biológica de quitina ....................................... 24

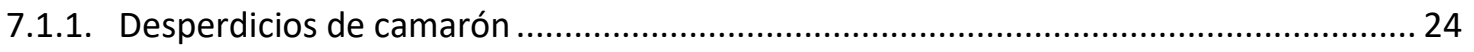

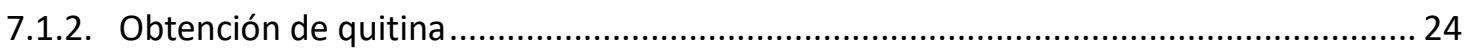


7.2. Obtención de lote de quitina mayor mediante el método biológico de extracción de quitina con mayores porcentajes de desmineralización y desproteinización.

7.3. Fibrilación de hojuelas de quitina para la obtención de nanofibrillas .............................. 28

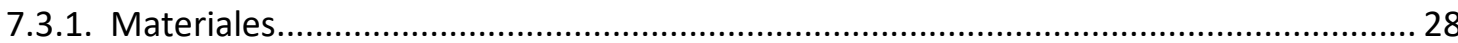

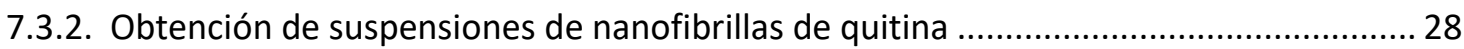

7.3.3. Preparación de películas de nanofibrillas de quitina .................................................. 29

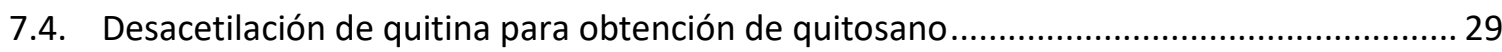

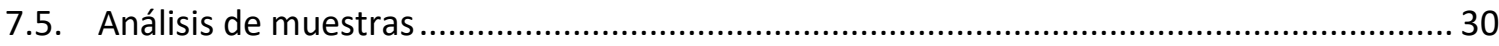

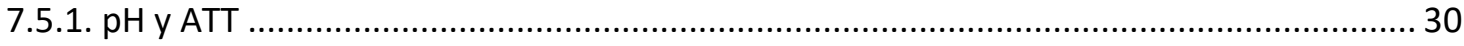

7.5.2. Determinación de azúcares, ácidos orgánicos y astaxantina........................................ 30

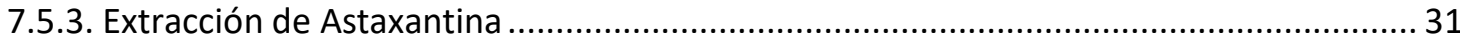

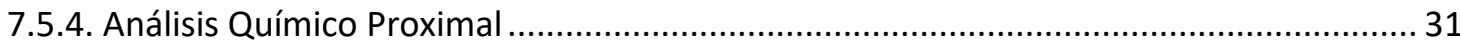

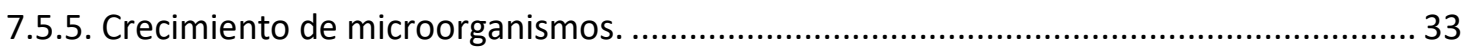

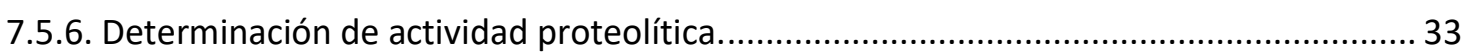

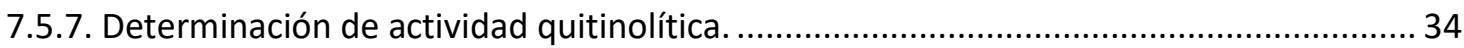

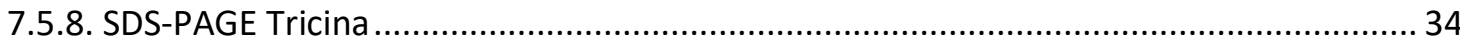

7.5.9. Zimogramas de actividad protelítica y quitinolítica..................................................... 35

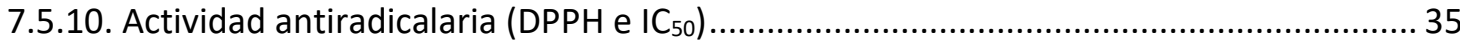

7.5.11. Caracterización de quitina, quitosano y nanofibrillas de quitina................................. 36

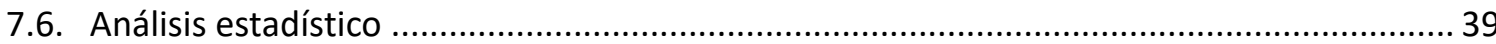

8. RESULTADOS

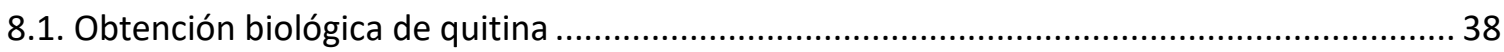

8.1.1. Desmineralización y desproteinización en la obtención de quitina mediante Deterzyme

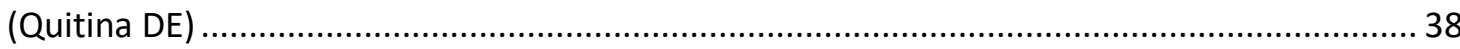

8.1.2. Cultivo en DC mediante inoculación sucesiva de Lactobacillus brevis y distintos niveles de Rhizopus oligosporus para la obtención de quitina. .......................................................... 40

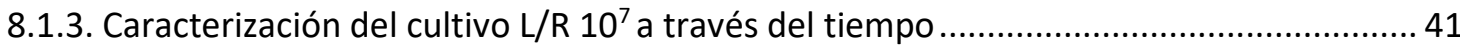

8.1.4. Caracterización y comparación de quitina DE y la obtenida mediante cultivo con

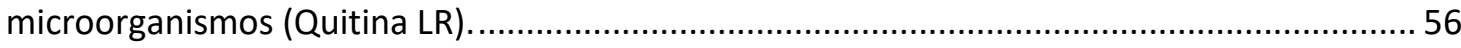

8.1.5. Conclusiones parciales sobre la extracción biológica de quitina ...................................60

8.2. Aplicación del cultivo L/R $10^{7}$ para generar mayor lote de quitina. ..................................... 61

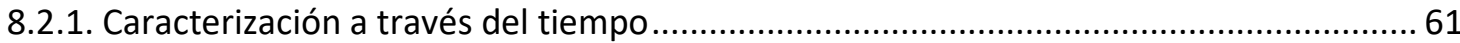

8.2.2. Conclusiones parciales sobre la utilización del cultivo L/R $10^{7}$ sobre $8 \mathrm{Kg}$ de DC..........64 
8.3. Fibrilación mediante tratamiento mecánico de quitinas extraídas biológicamente.

8.3.1. Comparación de quitina caracterizada previamente de acuerdo con el proceso de

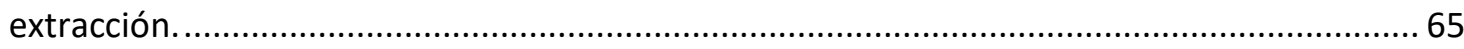

8.3.2. Viscosidad y transmitancia de las suspensiones de nanofibrillas de quitina (NFQ)........ 69

8.3.3. Cristalinidad y Estructura química de las suspensiones de NFQ .................................. 71

8.3.4. Caracterización de suspensiones de NFQ mediante SEM ............................................ 74

8.3.5. Transmitancia y propiedades mecánicas de películas de NFQ ....................................... 78

8.3.6. Conclusiones parciales sobre la obtención de NFQ y su uso para elaboración de películas.

8.4. Desacetilación de quitina proveniente del mayor lote de quitina obtenido mediante el

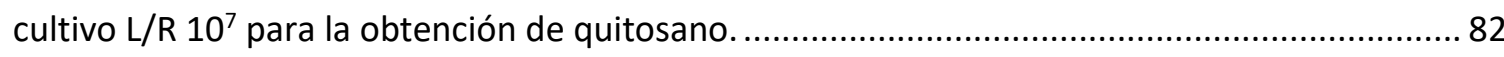

8.4.1. Caracterización mediante espectrofotometría infrarroja ............................................. 82

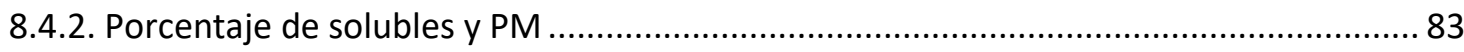

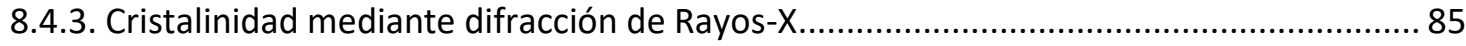

8.4.4. Conclusiones parciales sobre obtención de quitosano mediante desacetilación

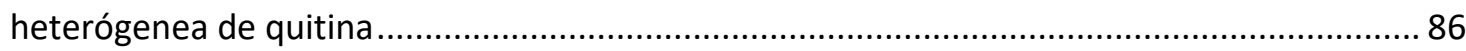

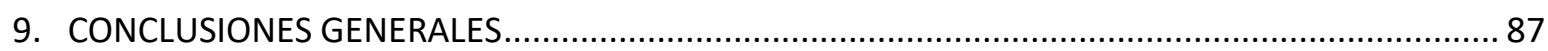

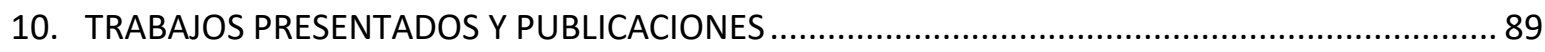

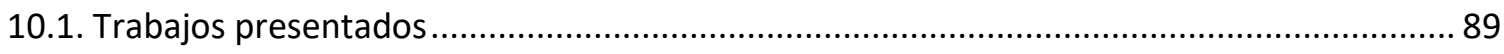

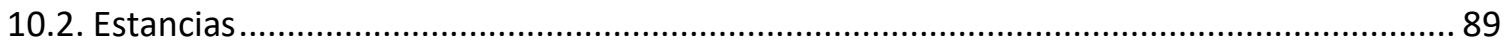

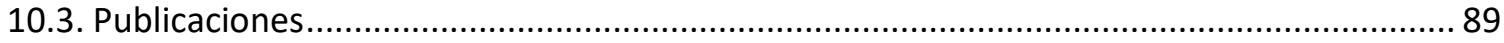

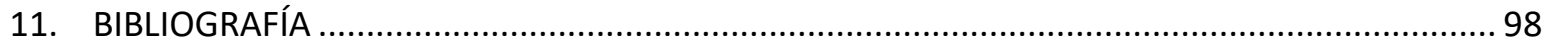

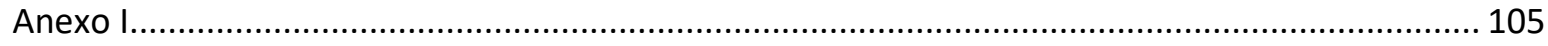

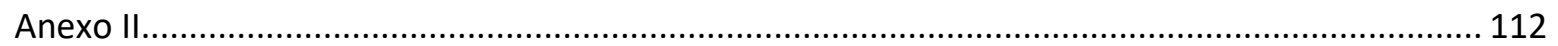

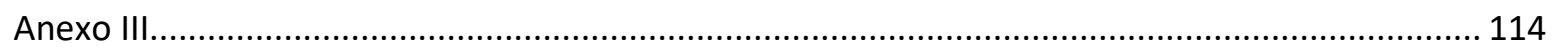

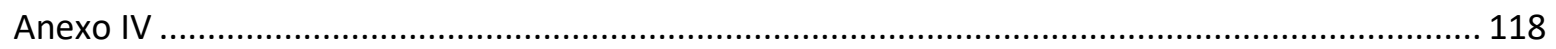




\section{LISTA DE FIGURAS}

Figura 1. Fibras de quitina en exoesqueleto de crustáceos...............................................................6

Figura 2. Estructura molecular de la quitina y quitosano...................................................................

Figura 3. Capas presentes en la cutícula de langosta Homarus americanus.......................................8

Figura 4. Proteína soluble removida de desechos de camarón mediante soluciones buffer y la enzima comercial Deterzyme.

Figura 5. pH y ATT del cultivo L/R107 realizando determinaciones cada $24 \mathrm{~h}$

. .42

Figura 6. Producción de ácidos orgánicos y consumo de glucosa del cultivo L/R10 7 determinada por HPLC. La flecha indica la adición de $10 \%$ de glucosa.

Figura. 7. DM y DP del cultivo L/R107 realizando determinaciones cada $24 \mathrm{~h}$. 45

Figura 8. Crecimiento de microorganismos en el licor del cultivo L/R10 ${ }^{7}$.......

Figura 9. Actividad proteolítica de enzimas a pH 7 y 5 presentes en licor del cultivo L/R107 y su comparación con las determinaciones de $\mathrm{pH}$.

Figura 10. Zimogramas de actividad protelítica a pH ácido y neutro de muestras tomadas cada $24 \mathrm{~h}$ del licor del cultivo L/R10 ${ }^{7}$.

Figura 11. Actividad de $\mathrm{N}$-acetil Hexosaminidasa en muestras tomadas cada $24 \mathrm{~h}$ del licor del cultivo L/R10 ${ }^{7}$. .51

Figura 12. Zimogramas de actividad quitinolítica de muestras tomadas cada $24 \mathrm{~h}$ del licor del cultivo L/R $10^{7}$...... .52

Figura 13. Concentración de proteína soluble e IC $\mathrm{C}_{50}$ presente en muestras de licor tomadas cada 24 $\mathrm{h}$ del cultivo $\mathrm{L} / \mathrm{R} 10^{7}$....... .53

Figura 14. SDS-PAGE Tricina de muestras tomadas cada $24 \mathrm{~h}$ del licor del cultivo L/R10 ${ }^{7}$ .53

Figura 15. Concentración de astaxantina extraída de la fracción sólida de muestras tomadas cada $24 \mathrm{~h}$ del cultivo L/R $10^{7}$ .54

Figura 16. IC 50 y concentración de astaxantina extraída de licor de muestras tomadas cada $24 \mathrm{~h}$ del cultivo L/R $10^{7}$.

Figura 17. Espectros infrarrojos obtenidos mediante ATR-FTIR de muestras de quitina extraída mediante Desproteinización enzimática, inoculación de microorganismos y su comparación con quitina comercial. .58 
Figura 18. $\mathrm{pH}$ y ATT de la repetición del cultivo L/R10 ${ }^{7}$ sobre $8 \mathrm{Kg}$ de $\mathrm{DC}$ realizando determinaciones cada $24 \mathrm{~h}$.

Figura 19. DM y DP de la repetición del cultivo L/R10 ${ }^{7}$ sobre $8 \mathrm{Kg}$ de $\mathrm{DC}$ realizando determinaciones cada $24 \mathrm{~h}$. .62

Figura 20. Micrografías de quitina de la repetición del cultivo L/R10 ${ }^{7}$ sobre $8 \mathrm{Kg}$ de DC obtenidas por SEM a diferentes objetivos.....

Figura 21. Espectros infrarrojos de muestras de quitina de los métodos $L$ y $L R$, antes y después de la decoloración, y su comparación con quitina comercial (Química)

Figura 22. Micrografías obtenidas por SEM en objetivo 30000x de muestras de hojuelas de quitina de los métodos biológicos LR y L .68

Figura 23. Viscosidad de las suspensiones de NFQ de los métodos L y LR de acuerdo a los pases a través del sistema Star Burst y su comparación con quitina química. .69

Figura 24. Transmitancia de las suspensiones de NFQ de los métodos $L$ y LR de acuerdo a los pases a través del sistema Star Burst y su comparación con quitina química. .70

Figura 25. Patrones de difracción de rayos $X$ de suspensiones de NFQ correspondientes a los métodos $L$ y $L R$ después de dos pases por molino. .72

Figura 26. Espectros infrarrojos de muestras de quitina en hojuela y suspensiones de nanofibrillas después de su molienda en condiciones ácidas, 30 y 100 pases por el sistema Star Burst. .73

Figura 27. Micrografías obtenidas por SEM en objetivo 30000x de suspensiones de NFQ del método LR después de distintos pases por el sistema Star Burst... .75

Figura 28. Micrografías obtenidas por SEM en objetivo 30000x de suspensiones de NFQ del método $L$ después de distintos pases por el sistema Star Burst. .76

Figura 29. Micrografías obtenidas mediante SEM a objetivo 30000x de suspensiones y películas de NFQ con y sin sonicación previa. . .77

Figura 30. Efecto de la sonicación en la transmitancia de películas de nanofibrillas de quitina a lo largo de pases por el sistema de alta presión (Star Burst). .78

Figura 31. Micrografía por SEM de la película LR blanqueada y sonicada mostrando el efecto de la fuerza aplicada en las pruebas mecánicas. .79

Figura 32. Fuerza de tensión de películas de nanofibrillas de quitina a través de pases por el sistema Star Burst. 80

Figura 33. Módulo de Young de películas de nanofibrillas de quitina a través de pases por el sistema Star Burst. 
Figura 34. Espectro infrarrojo de muestras de quitina después de 1, 2 y 3 h de desacetilación heterogénea y su comparación con quitosano comercial.

Figura 35. Espectro de $\mathrm{RMN} \mathrm{H}^{1}$ realizado en $\mathrm{DCl}+\mathrm{DOH}$ a $25^{\circ} \mathrm{C}(500 \mathrm{MHz})$ de muestra de quitosano después de $3 \mathrm{~h}$ de desacetilación.

Figura 36. Patrón de difracción de rayos $x$ a $\lambda=1.5418$ A en $2 \theta=4.5-70^{\circ} \mathrm{C}$ cada $0.02^{\circ}$ de quitosano después de $3 \mathrm{~h}$ de desacetilación .86

Figura 37. Curva patrón de seroalbúmina bovina para determinación de proteína soluble mediante Lowry-Peterson. 105

Figura. 38. Curva estándar de glucosa determinada mediante HPLC................................................106

Figura. 39. Curva estándar de ácido L-láctico determinada mediante HPLC....................................106

Figura 40. Curva estándar de ácido D-láctico determinada mediante HPLC....................................107

Figura 41. Curva estándar de ácido succínico determinada mediante HPLC.....................................107

Figura 42. Curva estándar de ácido acético determinada mediante HPLC.......................................108

Figura 43. Curva estándar de ácido oxálico determinada mediante HPLC........................................108

Figura 44. Curva estándar de ácido cítrico determinada mediante HPLC.........................................109

Figura 45. Curva estándar de ácido fumárico determinada mediante HPLC.....................................109

Figura 46. Curva estándar de ácido málico determinada mediante HPLC........................................110

Figura 47. Curva de $p$ nitrofenol para determinación de $\mathrm{N}$-acetil hexosaminidasa...........................110

Figura 48. Curva estándar de Trans-astaxantina determinada mediante HPLC...............................111

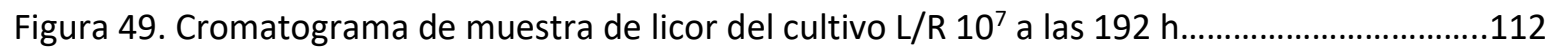

Figura 50. Cromatograma de muestra de astaxantina extraída del licor del cultivo L/R $10^{7}$ a las 192 h.

Figura 51. Cromatograma de muestra de astaxantina extraída de la fracción sólida del cultivo L/R $10^{7}$ a las $192 \mathrm{~h}$.

Figura 52. Espectro de $\mathrm{RMN} \mathrm{H}^{1}$ de la muestra final de quitina obtenida mediante desproteinización enzimática con la enzima comercial Deterzyme ${ }^{\circledR}$...... 
Figura 53. Espectro de RMN H1 de la muestra final de quitina obtenida mediante inoculación de Lactobacillus brevis y Rhizopus oligosporus en desperdicios de camarón...

Figura 54. Espectro de $\mathrm{RMN} \mathrm{H}^{1}$ de quitina $\mathrm{L}$ diluida en $\mathrm{DCl}+\mathrm{D} 2 \mathrm{O}$ a $25^{\circ} \mathrm{C}(500 \mathrm{MHz})$ 115

Figura 55. Espectro de RMN H ${ }^{1}$ de quitina $\mathrm{L}$ blanqueada diluida en $\mathrm{DCl}+\mathrm{D} 2 \mathrm{O}$ a $25^{\circ} \mathrm{C}(500 \mathrm{MHz}) . .115$

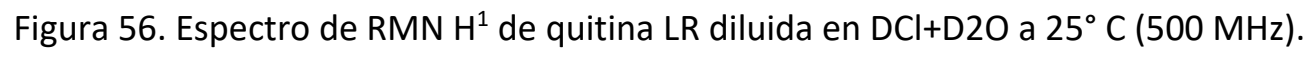
116

Figura 57. Espectro de $\mathrm{RMN} \mathrm{H}^{1}$ de quitina $\mathrm{LR}$ blanqueada diluida en $\mathrm{DCl}+\mathrm{D} 2 \mathrm{O}$ a $25^{\circ} \mathrm{C}(500$ $\mathrm{MHz})$ 116

Figura 58. Espectro de $\mathrm{RMN} \mathrm{H}{ }^{1}$ de quitina comercial diluida en $\mathrm{DCl}+\mathrm{D} 2 \mathrm{O}$ a $25^{\circ} \mathrm{C}(500 \mathrm{MHz}) \ldots \ldots . .117$

Figura 59. Patrón de difracción de rayos $x$ a $\lambda=1.5418 \mathrm{~A}$ en $2 \theta=4.5-70^{\circ} \mathrm{C}$ cada $0.02^{\circ}$ de quitina desmineralizada del cultivo L/R $10^{7}$ a las $192 \mathrm{~h}$ 


\section{LISTA DE TABLAS}

Tabla 1. Soluciones utilizadas para la extracción enzimática de quitina.............................................25

Tabla 2. Diseño experimental variando nivel de inóculo de Rhizopus oligosporus.............................27

Tabla 3. Constantes para determinación de peso molecular................................................................37

Tabla 4. Resultados de pH, ATT, DM y DP obtenidos en el tiempo final de los cultivos con inoculación de Lactobacillus brevis y distintos niveles de Rhizopus oligosporus.

Tabla 5. Grado de acetilación y peso molecular correspondiente a las quitinas obtenidas por métodos biológicos.

Tabla 6. Caracterización de quitina de acuerdo con el método de obtención, proceso de decoloración y su comparación con quitina comercial.. 66 
ABREVIATURAS

L: Tratamiento de obtención de quitina mediante inoculación de Lactobacillus brevis

R: Rhizopus oligosporus

LR: Tratamiento de obtención de quitina mediante inoculación de Lactobacillus brevis y Rhizopus oligosporus

ATT: Acidez Total Titulable

DM: Desmineralización

DP: Desproteinización

$\mathrm{N}$-hasa: N-acetil hexosaminidasa

NF: Nanofibrillas

DC: Desperdicios de camarón

DPPH: 2,2-diphenyl-1-picrylhydrazyl

UFC: Unidad Formadora de Colonias

SMA: Agar Métodos Estándar

MRS: Agar Man Rogosa Sharpe

EMB: Agar Eosina Azul de Metileno

PDA: Agar Papa Dextrosa

DMAc: N, N-dimetilacetamida

SEM: Microscopia Electrónica de Barrido

DE: Desproteinización enzimática

$\mathrm{RMN} \mathrm{H}^{1}$ : Resonancia Magnética Nuclear de protón

PM: Peso Molecular

DA: Grado de acetilación 
ICR: Índice de cristalinidad

IR: Espectrofotometría Infrarrojo

NFQ: Nanofibrillas de quitina

$\mathrm{D}_{2} \mathrm{O}$ : Agua deuterada

DCl: Ácido clorhídrico deuterado

KDa: Kilodalton

SDS-PAGE: Electroforesis en geles de poliacrilamida empleando dodecil sulfato de sodio 
RESUMEN

\section{RESUMEN}

La quitina y el quitosano (obtenido por la desacetilación de la quitina), son biopolímeros extraídos de desperdicios de crustáceos que cuentan con distintas aplicaciones, como médicas y farmacéuticas, entre otras. La quitina se extrae comúnmente mediante el uso de químicos para eliminar los minerales y proteínas que se encuentran embebidos en la matriz de quitina, lo que genera residuos contaminantes, evita la obtención de otros productos de valor agregado y afecta las características del biopolímero; por lo que actualmente la investigación del uso de métodos biológicos para su extracción se ha tomado importancia. En este trabajo, se compararon dos métodos de obtención biológica de quitina a partir de desperdicios de camarón: 1) Mediante desproteinización enzimática utilizando la enzima comercial Deterzyme ${ }^{\circledR}$ y 2) Mediante la inoculación sucesiva de una bacteria láctica (Lactobacillus brevis) y un hongo proteolítico (Rhizopus oligosporus). El último método (L/R $10^{7}$ ) presentó $96.91 \%$ de desproteinización, porcentaje mayor que el obtenido mediante desproteinización enzimática (79.44\%). La quitina proveniente del proceso mediante inoculación de microorganismos presentó un peso molecular de 4,273 kDa; mientras que con el uso de Deterzyme ${ }^{\circledR}$ fue de 1,338 kDa. La cristalinidad relativa del método mediante cultivo de microorganismos fue igualmente alta (89.7\%). Por lo anterior se repitió este último método (L/R $\left.10^{7}\right)$, procesando $8 \mathrm{~kg}$ de desperdicios que generaron $647 \mathrm{~g}$ de quitina, los cuales se utilizaron para obtener nanofibrillas y quitosano. Las suspensiones de nanofibrillas de quitina se obtuvieron usando la quitina obtenida del lote mayor del cultivo L/R $10^{7}(\mathrm{LR})$, así como quitina procedente de un proceso de fermentación con L. brevis como único microorganismo (L) y de extracción química (muestra comercial) con un equipo micronizador mediante agua a alta presión (Star Burst Mini), permaneciendo estables como suspensiones de nanofibras hasta por 4 meses después de la fibrilación. La viscosidad y transmitancia de las muestras de quitina de los métodos L y LR aumentaron hasta los 30 pases por el sistema a alta presión, después de lo cual la viscosidad disminuyó y la transmitancia se mantuvo constante, indicando la completa fibrilación de la quitina. Sin embargo, la transmitancia (50\%) de las suspensiones 
RESUMEN

de quitina procedentes de muestras biológicas ( $L$ y $L R$ ) fue menor comparado con las suspensiones de nanofibras de quitina comercial (70\%) debido a los pigmentos residuales. Por lo anterior se blanquearon utilizando hipoclorito de sodio, lo que aumentó la transmitancia de las suspensiones de nanofibras (72\%) y facilitó la fibrilación de las quitinas, siendo necesarios sólo 10 pases a través del equipo Star Burst para obtener nanofibrillas de quitina. Este resultado coincidió con micrografías por Microscopia Electrónica de Barrido, las cuales mostraron el proceso de fibrilación a través de los pases, hasta completarla a los 10 pases. Se elaboraron películas a partir de las suspensiones de nanofibras, realizando un tratamiento de sonicación para aumentar la transmitancia, obteniendo que a pesar de que el blanqueado y la sonicación aumentaron el porcentaje de transmitancia, esta permaneció por debajo de $22 \%$, porcentaje menor del obtenido con nanofibrillas de quitina extraída químicamente (comercial), que fue de $80 \%$. La fuerza de tensión de las películas de nanofibras de quitina L y LR fue de $58 \mathrm{MPa}$, resultado cercano a los $65 \mathrm{MPa}$ reportados para las películas de nanofibras de quitina comercial. El módulo de Young de las películas de quitinas extraídas biológicamente fue de 5,000 MPa, superior a los 2,800 MPa reportados igualmente para películas de nanofibras de quitina comercial, por lo que el uso de quitina extraída biológicamente aumenta el módulo elástico de las películas elaboradas de nanofibras de quitina. El quitosano se obtuvo por desacetilación heterogénea de la quitina extraída biológicamente mediante en el lote de 8 kg de desperdicios, utilizando $\mathrm{NaOH}$ al $50 \%$ a $100^{\circ} \mathrm{C}$. El quitosano presentó grado de acetilación de $71.87 \%$, peso molecular de $325 \mathrm{KDa}$ (correspondiente a quitosano de alto peso molecular) y cristalinidad relativa de $87.70 \%$. La cristalinidad obtenida fue similar a la cristalinidad correspondiente a la quitina; por lo que el alto peso molecular de la quitina procediente del lote mayor usada para obtener quitosano permite obtener un quitosano igualmente con alto peso molecular y cristalinidad. La quitina extraída mediante la inoculación sucesiva de Lactobacillus brevis y Rhizopus oligosporus (L/R 107) presenta mejores características que la quitina extraída químicamente (comercial), resultando en mayor módulo elástico de las películas de nanofibrillas además de permitir la obtención de quitosano de alto peso molecular. Las características anteriores son ejemplo de las 
RESUMEN

ventajas al utilizar alternativas biológicas para obtención de la quitina de desperdicios de camarón. 


\section{ABSTRACT}

Chitin and chitosan, obtained by chitin deacetylation, are biopolymers extracted from crustacean wastes and presents many applications, such as medical and pharmaceutical, among others. Chitin is commonly extracted with the use of chemicals to remove minerals and protein which are embedded within the chitin matrix, generating polluting waste, impairing by-products recovery and affecting biopolymer properties; therefore, the current investigation focuses on biological extraction methods. The present work compared two biological chitin extraction methods from shrimp wastes: 1) Enzymatic deproteinization by commercial enzyme Deterzyme ${ }^{\circledR}$ and 2) By successive inoculation of a lactic acid bacteria (Lactobacillus brevis) and a proteolytic fungus (Rhizopus oligosporus) on shrimp wastes. The latter method showed deproteinization of $96.91 \%$, higher value than the one resulting from enzymatic deproteinization (79.44\%). Chitin from successive inoculation method showed molecular weight of 4,273 kDa, meanwhile Deteryme ${ }^{\circledR}$ method showed lower molecular weight of 1,338 kDa. Relative crystallinity of chitin from microorganisms inoculation method was also high, showing $89.7 \%$. Thus, fermentation method (L/R $\left.10^{7}\right)$ was tested on $8 \mathrm{~kg}$ of shrimp wastes, resulting in $647 \mathrm{~g}$ of total purified chitin that was divided and used for nanofibers and chitosan obtaining. Chitin nanofibers were obtained by using chitin from the highest batch (LR), also a chitin sample from a lactic acid fermentation process only with L. brevis (L), and chemically extracted chitin (commercial sample) treating them with a high-pressure water jet system (Star Burst Mini), remaining stable after fibrillation up to 4 months as nanofiber suspensions. Viscosity and transmittance of chitin samples L and LR increased until 30 passes through Star Burst, after that viscosity decreased and transmittance remained constant, indicating chitin fully fibrillation. However, the transmittance (50\%) of biological chitin nanofiber suspensions ( $L$ and $L R$ ) was lower compared with samples from commercial chitin nanofibers suspensions (70\%) due to residual pigments. Therefore, samples were discolorated with sodium hypoclorite, increasing nanofiber suspensions transmittance (72\%) accomplishing chitin fibrillation with only 10 passes through Star Burst for chitin 


\section{ABSTRACT}

nanofiber obtaining. Scanning Electron Microscopy confirmed the result, showing fibrillation process through Star Burst passes until 10 passes. Nanofibers sheets were elaborated from regular nanofiber suspensions and later they were sonicated to increase nanofiber sheets transmittance, which despite of showing an increment, it remained below $22 \%$, lower percentage than the $80 \%$ obtained from chemically extracted chitin (commercial). The tensile strength of sheets from L and LR chitin nanofibers was $58 \mathrm{MPa}$, being close to the $65 \mathrm{MPa}$ previously reported for commercial chitin nanofibers sheets. Young's modulus of sheets from biologically extracted chitin was 5,000 MPa, higher than the 2,800 MPa reported for commercial chitin nanofibers sheets; hence, fibrillation of biologically extracted chitin increase sheets elastic modulus. Chitosan was obtained by heterogeneous deacetylation from largest batch of the $L / R 10^{7}$ culture using with $50 \%$ $\mathrm{NaOH}$ at $100^{\circ} \mathrm{C}$. Chitosan showed an acetylation degree of $71.87 \%$, molecular weight of $325 \mathrm{kDa}$ (corresponding to high molecular weight chitosan) and relative crystallinity of 87.70\%. Resulting chitosan crystallinity was similar to chitin crystallinity; therefore, the use of high molecular weight chitin for chitosan production resulted in crystalline and high molecular weight chitosan. Chitin extracted through successive inoculation of Lactobacillus brevis and Rhizopus oligosporus (L/R 107) improved chitin characteristics compared with chemically extracted chitin (commercial), also increasing nanofibers sheets elastic modulus and allowing high molecular weight chitosan. These characteristics are an example of the advantages from the use of biological alternatives for chitin obtaining from shrimp wastes. 


\section{IN EXTENSE ABSTRACT}

Both chitin and chitosan present several applications according to their extraction treatment or purification techniques. Thus, future applications will delimit the search for new methods to generate different biopolymer characteristics. Besides, the accomplishment of other by-products recoveries from crustacean wastes, which are the principal source for chitin and chitosan.

Chitin is arranged in crustacean shells as microfibrils in an antiparallel fashion embedded in protein and calcium carbonate matrix. Protein and minerals removed from shells for chitin purification, this is commonly achieved by strong acid and alkali, to obtain purified chitin. Later on, it can be treated with chemical or physical methods for nanofibers production. In spite of the several applications of chitin, its strong intermolecular hydrogen bonding makes this biopolymer insoluble in most solvents, which difficult its use. On the other hand, chitin microfibrils extraction can be achieved as nanofibers by the utilization of a Star Burst atomization system, conferring different properties to chitin, allowing its use in other applications such as materials reinforcement, medical treatment, and agriculture.

Chitosan, commonly obtained by chitin deacetylation, is soluble in most solvents besides presenting antimicrobial activity, increasing its application to the pharmacy, food, water treatment, tissue engineering, textile and cosmetic, among others. However, the use depends on the molecular weight and acetylation degree, increasing solubility as acetylation decrease.

Two biological extraction methods on shrimp wastes were investigated: 1) commercial proteases to remove residual protein after use of buffer solutions and 2) successive inoculation of lactic acid bacteria (Lactobacillus brevis) and proteolytic fungus (Rhizopus oligosporus) using $20 \%$ total glucose as carbon source. Both treatments searched high mineral and protein removal to obtain purified chitin without the use of chemicals. The method with higher demineralization and deproteinization was repited on $8 \mathrm{~kg}$ of shrimp 
wastes to achieve chitin nanofibers and deacetylation to chitosan. Nanofibers obtained through mechanical treatment under acidic conditions from biologically extracted chitin for further nanofiber sheets elaboration. Biological extraction is efficient for chitin obtaining compared with chemical extraction, accomplishing diminishing of pollution and nanofiber elaboration. On the other hand, due to chitin high molecular weight and crystallinity, its deacetylation resulted in chitosan with same characteristics, despite the strong chemical treatment for deacetylation.

Investigation showed that biological treatment on shrimp wastes was effective for chitin obtaining, besides other by-products like protein hydrolysates and pigments, such as astaxanthin, both presenting industrial potential. This join to the possibility of nanofibers and high molecular weight chitosan was obtaining.

\section{CHITIN EXTRACTION BY BIOLOGICAL METHODS}

For protein removal by commercial enzymes, dry shrimp wastes were minced and washed with two buffer solutions (Solution A: $\mathrm{Na}_{2} \mathrm{HPO}_{4}+\mathrm{KH}_{2} \mathrm{PO} 4$ and Solution B: Solution $\mathrm{A}+\mathrm{KCl}$, both at $\mathrm{pH}$ 7) for 10 minutes at room temperature for sarcoplasmic and myofibrillar protein removal, respectively. Later, shrimp wastes were demineralized with $\mathrm{HCl} 0.5 \mathrm{M}$ and dried. The residual protein (stromal) was removed with the use of Deterzyme ${ }^{\circledR}$ at $1.61 \%$ for $4 \mathrm{~h}$ at $40^{\circ} \mathrm{C}$. Latter was rinsed with distilled water at $25^{\circ} \mathrm{C}$ until water was clear and dried at $40^{\circ} \mathrm{C}$ for $24 \mathrm{~h}$ and reserved for further analysis. The demineralization was $79.68 \%$ and deproteinization of $74.44 \%$, lower values than previously reported; however, characterization through FTIR spectroscopy showed biopolymer purification.

The use of lactic acid bacteria and proteolytic fungi was performed by their inoculation for $120 \mathrm{~h}$ and $72 \mathrm{~h}$, respectively. 10\% glucose with added each inoculum and, the culture

maintained at $30^{\circ} \mathrm{C}$. Fungal inoculum level tested initially. Later, the solid fraction (chitin) separated from culture was rinsed with current water at room temperature until water 
was clear and dried at $25^{\circ} \mathrm{C}$. The chitin purified with the highest fungal inoculum level $\left(10^{7}\right.$ spores/g) presented demineralization of $67.3 \%$ and deproteinization of $96 \%$, being this last one higher than reported elsewhere.

The inoculation of microorganisms on shrimp wastes showed higher deproteinization with largest fungal inoculum level, compared with the use of Deterzyme ${ }^{\circledR}$. Therefore, the study of microorganisms used continued to improve products characteristics. The liquid fraction (liquor) from the culture with inoculation of $5 \%$ L. brevis and $10^{7}$ spores of $R$. oligosporus analyzed for determination of protein, organic acids, microbial growth, proteolytic activity, pigments and antioxidant activity. Chitin obtained was demineralized with $\mathrm{HCl} 0.5$ $M$ and characterized by IR, H1 NMR for acetylation degree, X-ray diffraction for crystallinity and viscosity for molecular weight and soluble matter.

The highest organic acid produced was lactic acid reaching up to $0.5 \mathrm{mmol} / \mathrm{g}$, however succinic, oxalic and acetic acids were also produced in lower concentrations, indicating an heterofermentative metabolic pathway. Protein concentration in liquor reached up to 120 $\mathrm{mg} / \mathrm{g}$ at 96 culture hours, coinciding with high proteolytic activity as pH decrease (after 24 h) as reported for proteases from Rhizopus oligosporus, which are stable at pH of 5 . Activity zymograms reinforced this result, showing higher proteolytic activity in acid $\mathrm{pH}$ $(2.9 \mathrm{U} / \mathrm{mL})$ than neutral $\mathrm{pH}(0.8 \mathrm{U} / \mathrm{mL})$. Protein hydrolysates showed an $\mathrm{IC}_{50}$ activity of $1.15 \mathrm{mg} / \mathrm{g}$ at $168 \mathrm{~h}$, indicating that the longer culture time was, the lowest protein amount is needed to reach $50 \%$ antioxidant activity. Protein molecular weight was less than 6.5 $\mathrm{kDa}$ once fungi were inoculated, as showed by Tricine SDS-PAGE, indicating highly proteolytic activity. Mesophile and lactic acid bacteria were prevalent through culture, presenting small decrease once fungal inoculation at $120 \mathrm{~h}$. This last one remained constant along culture and coliforms were inhibited in first hours. Chitinolytic activity for $\mathrm{N}$-acetylhexosaminidase was present at $0.0012 \mathrm{U} / \mathrm{mg}$ protein, however, Endochitinase activity was not detected. Activity zymograms showed same results, indicating that Endochitinase activity was almost imperceptible. Astaxanthin concentration was determined from solid and liquor, showing that highest concentration was found in the 
solid, resulting $47 \mu \mathrm{g}, 37 \mu \mathrm{g}$ and $38 \mu \mathrm{g}$ of trans-, 9-cis, and 13-cis isoform, respectively; while astaxanthin in liquor only presented the trans-isoform $(8 \mu \mathrm{g})$. Antioxidant activity (IC $\left.\mathrm{C}_{50}\right)$ of astaxanthin from liquor was of $2 \mu \mathrm{g}$ at $48 \mathrm{~h}$ of culture; thus, higher antioxidant activity in liquor ascribed to protein instead of astaxanthin.

Chitin IR spectra showed all characteristic bands, ensuring biopolymer purification. Acetylation degree and crystallinity index were $94.65 \%$ and $95.71 \%$, respectively. The molecular weight of chitin was $4,273 \mathrm{kDa}$ with $14.41 \%$ of the soluble matter in $\mathrm{N}, \mathrm{N}$-dimethylacetamide containing lithium chloride $(5 \% \mathrm{w} / \mathrm{v})$. Chitin characteristics maintained with biological extraction, compared with chemical extraction.

Extraction method by culture with microorganisms was effective for chitin obtaining and other by-products, such as protein hydrolysates, proteolytic enzymes, and pigments, therefore, this method was tested on $8 \mathrm{~kg}$ of shrimp wastes with same culture conditions. Chitin obtained was characterized after demineralization with $\mathrm{HCl} 0.5 \mathrm{M}$ by IR showing the characteristic bands. Acetylation degree and relative crystallinities were $94.10 \%$ and $89.7 \%$, respectively. The molecular weight was $3,693 \mathrm{kDa}$ with $9.66 \%$ soluble matter, indicating high molecular weight; thus, chitin obtained from $8 \mathrm{Kg}$ batch was used for nanofibers and chitosan obtaining.

\section{CHITIN FIBRILLATION FOR NANOFIBERS OBTAINING}

Three chitin samples were used: chitin highest batch (LR), chitin obtained by fermentation with lactic acid bacteria (L) and commercial chitin (C). All samples were treated with grinder and a high-pressure water jet system in acidic conditions. Viscosity (700 cP) increased until 10 passes, decreasing after that, indicating that after 10 passes, fibers started to break. SEM characterization showed the progressive chitin fibrillation as passes increased, accomplishing fibrillation fully at 10 passes, as showed by viscosity results. Chitin nanofibers suspensions transmittance at $600 \mathrm{~nm}$ was lower than $60 \%$. Therefore, 
IN EXTENSE ABSTRACT

samples from highest chitin batch (LR) and obtained by fermentation with lactic acid bacteria (L) were discolorated with domestic bleach, after which, transmittance increase until $70 \%$, a lower value than the one reported for nanofibers suspensions from chemical chitin (90\%). The relative crystallinity in all samples decreased after only 2 passes through the grinder, declining from $89 \%$ for chitin flake to $70 \%$ for nanofiber suspensions. However, the relative crystallinity remained the same even after 100 passes through the high-pressure water jet system. Also, nanofiber suspension was used for sheets elaboration, employing aside from discolorated chitin, sonication of suspensions for 5 minutes. Bleaching of chitin and sonication of nanofiber suspensions resulted in higher sheets transmittance, increasing up to 47\%; however, this percentage was still lower than the $80 \%$ reported for chemically extracted chitin; thus, thoroughly chitin discoloration is recommended to increase sheets transparency. On the other hand, mechanical sheets characterization showed that tensile strength from $L$ and $L R$ nanofiber sheets was around $58 \mathrm{MPa}$, similar value than the one reported for commercial chitin. The Young's modulus in all biologically extracted chitin nanofiber suspensions was higher, compared with values from chemical chitin, reaching up to 5,000 MPa at 10 passes through the high-pressure water jet system, indicating that biologically extraction chitin method improves elastic properties on nanofiber sheets.

The LR chitin obtained from the $8 \mathrm{Kg}$ batch process presented higher transmittance, tensile strength, and Young's modulus after discoloration. The nanofibers suspension sonicated before sheets elaboration, showing that extraction by successive inoculation of Lactobacillus brevis and Rhizopus oligosporus is an efficient method for chitin obtaining and fibrillation to nanofiber through mechanical treatment, diminishing the use of chemicals for nanofibers obtaining.

\section{CHITOSAN OBTENTION BY CHITIN HETEROGENEOUS DEACETYLATION}


High molecular weight and crystalline chitin from highest batch culture (LR method) was treated with $\mathrm{NaOH} 50 \%$ at $100^{\circ} \mathrm{C}$ for $3 \mathrm{~h}$, taking samples every hour, for chitosan obtaining. Samples collected were rinsed until neutrality and dried. IR characterization showed progressive chitosan obtaining as treatment hours passed, as observed by changes in peaks at $1650-1620 \mathrm{~cm}^{-1}$. Soluble matter in an acetic acid solution increased up to $75 \%$ at $3 \mathrm{~h}$ treatment with $\mathrm{NaOH}$, indicating that $3 \mathrm{~h}$ of chemical treatment is necessary to diminish acetylation degree of biopolymer for chitosan obtaining. DA after $3 \mathrm{~h}$ treatment resulted in $28.13 \%$. Thus, biopolymer obtained after $3 \mathrm{~h}$ deacetylation is effectively chitosan. The molecular weight was $325 \mathrm{kDa}$, corresponding to high molecular weight chitosan; therefore, the use of chitin with high molecular weight is sufficient for high molecular weight chitosan obtaining, even with the use of high temperature and concentrated alkali. Relative crystallinity $(87.70 \%)$ of chitosan showed that chemical treatment did not affect biopolymer crystallinity. Thus, chitin biologically obtained by culture with microorganism is an efficient method for chitin obtaining and its posterior deacetylation to high molecular weight chitosan.

\section{GENERAL CONCLUSIONS}

The use of microorganisms on shrimp wastes for chitin obtaining presented higher deproteinization than the use of buffer solutions and commercial enzymes, besides allowing by-products recovery; thus, biological chitin extraction method by inoculation of Lactobacillus brevis and Rhizopus oligosporus for chitin, protein, enzymes and pigments recovery. Chitin obtained by this biological method can be used for nanofiber obtaining by mechanical fibrillation, increasing elastic modulus of chitin nanofibers sheets compared with commercial chitin. This chitin can also be employed for chitosan obtaining by heterogeneous deacetylation, generating highly crystalline and high molecular weight chitosan. 
INTRODUCCIÓN

\section{INTRODUCCIÓN}

La producción de camarón en México en el 2012 fue de 161,852 ton, de las cuales el 45\% aproximadamente son desperdicio, por lo que se producen 72,830 ton de desechos que se convierten en una fuente de contaminación biológica (Anuario Estadístico de Acuacultura y Pesca, 2013). Estos desechos pueden aprovecharse para la obtención de productos como la quitina, que es un componente del exoesqueleto de crustáceos; así como otros compuestos de valor agregado, como concentrados de proteína o pigmentos, que son productos de interés industrial.

Tanto la quitina como su derivado desacetilado, el quitosano, son compuestos renovables, biodegradables, no tóxicos, biofuncionales y biocompatibles, debido a su origen biológico, por lo que se les confieren una gran cantidad de usos, como son: ingeniería de tejidos, alimentos, cosméticos, textiles, pinturas, medicina y tratamiento de aguas, entre otros (Jian-Bing et al., 2011; Yeul y Rayalu, 2013).

La quitina se obtiene comúnmente mediante el uso de ácidos y álcalis fuertes en los desechos de camarón, con el fin de remover el carbonato de calcio y proteínas que son componentes del exoesqueleto del camarón junto con la quitina. Sin embargo, esto genera residuos contaminantes, disminuyendo así el efecto de aprovechamiento de los residuos pesqueros; además de no permitir la obtención de otros componentes de valor agregado como las proteínas y de alterar las características de la quitina, lo que puede implicar menos aplicaciones. Por lo anterior, han sido investigados métodos más amigables con el ambiente, como son: la fermentación, especificamente empleando bacterias lácticas y/o altamente proteolíticas o bien la desproteinización enzimática mediante el uso de enzimas comerciales o extraídas de cultivos de microorganismos; esto con el fin de que el ácido láctico generado remueva los minerales de la cutícula, mientras que las enzimas producidas por los microorganismos o agregadas a los desperdicios, remueven la proteína, facilitando la purificación de la quitina. Ambos métodos tienen la ventaja de disminuir el uso de químicos y mejorar las propiedades de la quitina; sin embargo, tienen la desventaja de necesitar largos periodos de tiempo, lo que dificulta su 


\section{INTRODUCCIÓN}

utilización a escala industrial. Por lo anterior, se siguen investigando variantes de métodos de extracción que mantengan las características del biopolímero, que requieran menos recursos que los métodos actuales y que disminuyan el efecto contaminante (Younes y Rinaudo, 2015).

Otro aspecto del aprovechamiento de desperdicios de camarón es la obtención de hidrolizados proteicos, los cuales pueden ser utilizados como suplemento alimenticio o como fuente de nitrógeno para medios de cultivo de microorganismos, así como la recuperación de pigmentos, como la astaxantina, los cuales cuentan con alta actividad antioxidante.

La quitina tiene alto potencial, principalmente por ser la fuente para la obtención de quitosano, ya que el uso de la quitina es limitado debido a su baja solubilidad en ácidos orgánicos, como el ácido acético; mientras que el quitosano es altamente soluble, además de presentar actividad antimicrobiana debido a los grupos aminos que quedan libre después de la desacetilación de la quitina. Por lo que se busca que, mediante cambios estructurales, la quitina pueda ser utilizada para otras aplicaciones, sin necesidad de su tratamiento para obtener quitosano. Uno de estos cambios, es la fibrilación de la quitina (obtenida como hojuelas y molida hasta obtener un polvo amarillento), con el fin de reducirla hasta su conformación original, aglomerados de nanofibrillas de quitina. La obtención de nanofibrillas de quitina se ha estudiado mediante electrospinning y otros métodos como la solubilización de la quitina en solventes como la $\mathrm{N}$-dimetilacetamida (un solvente que es tóxico) para su posterior recuperación como nanofibrilla al eliminar el solvente. Sin embargo, ambos métodos presentan cierta dificultad para su escalamiento, por lo que se han investigado métodos más sencillos. Uno de estos es la molienda de la quitina en condiciones ácidas, lo que facilita la fibrilación del biopolímero y al aumentar el tratamiento mecánico, disminuye el entrecruzamiento de fibras, resultando en la obtención de nanofibrillas (Ifuku et al., 2009). Al obtener la quitina como nanofibrillas, se aumenta la superficie de respuesta, y a pesar de que las fibras no son solubles, suelen ser

fácilmente dispersables en agua $u$ otros solventes, facilitando su uso en distintas 


\section{INTRODUCCIÓN}

aplicaciones, como son la agricultura, la liberación de medicamentos, el tratamiento de heridas, la producción de textiles y fibra alimentaria, entre otras (Ifuku y Saimoto, 2012). El quitosano, por su parte, presenta una amplia gama de aplicaciones que dependen del porcentaje de fracciones acetiladas que presente y de su peso molecular, los cuales varían dependiendo del tratamiento de desacetilación de la quitina. Normalmente, la desacetilación se lleva a cabo usando álcalis altamente concentrados; además de largos periodos de tiempo o altas temperaturas, lo que aumenta la remoción de los grupos acetilo, pero disminuye el peso molecular; por lo que mientras menor sea el grado de acetilación, menor será el peso molecular. Por lo anterior, también se investigan métodos que permitan disminuir considerablemente el grado de acetilación del quitosano manteniendo el peso molecular, como son la utilización de una atmósfera de nitrógeno durante la reacción de desacetilación, el uso de álcalis menos concentrados por periodos de tiempo más largos, la aplicación de enzimas desacetilasas que produzcan un patrón de fracciones acetiladas distinto a los obtenidos con métodos químicos o el uso de métodos físicos, como microondas y sonicación.

Tanto la quitina como el quitosano tienen una amplia gama de aplicaciones, dependiendo del tratamiento por el cual se hayan extraído o el tratamiento posterior al que sean sometidos, por lo que las aplicaciones futuras requieren la búsqueda de nuevos métodos para generar distintas propiedades en los biopolímeros, así como la posibilidad de lograr un completo aprovechamiento de los desechos de crustáceos.

En el presente trabajo se investigaron dos métodos biológicos de extracción. En el primero se probó la utilización de lavados con soluciones buffer aunado a una proteasa comercial (Deterzyme ${ }^{\circledR}$ ) para remover la proteína de los desperdicios de camarón. En el segundo método se probó la inoculación sucesiva de dos microorganismos, una bacteria láctica y un hongo altamente proteolítico, en los desperdicios. Se buscó que los métodos lograran el mayor porcentaje de remoción de proteína y minerales presentes en los desperdicios de camarón para obtener quitina purificada sin la intervención de solventes químicos, además de poder recuperar la proteína y pigmentos presentes en los desechos. De los métodos mencionados, la inoculación sucesiva de microorganismos fue el que presentó 


\section{INTRODUCCIÓN}

mayores porcentajes de desmineralización y desproteinización, por lo que fue elegido para obtener un mayor lote de quitina utilizando la inoculación sucesiva sobre $8 \mathrm{~kg}$ de desperdicio de camarón. Este procedimiento se realizó con el fin de verificar la eficacia del método biológico con mayor cantidad de desperdicio y obtener la suficiente cantidad de quitina para obtener quitosano y nanofibrillas de quitina.

Las nanofibrillas de quitina se obtuvieron mediante un tratamiento mecánico en condiciones ácidas de la quitina obtenida biológicamente en el escalamiento a $8 \mathrm{Kg}$ y se utilizaron para elaborar películas de nanofibrillas, probando la eficacia de la extracción biológica de quitina en comparación con la extracción química tradicionalmente usada para obtener quitina de los desperdicios de camarón. Logrando de esta manera disminuir considerablemente el uso de químicos, tanto para la obtención de quitina, como para su fibrilación a nanofibrillas.

Por otra parte, gracias a que la quitina obtenida en el escalamiento presentó alto peso molecular y cristalinidad, su desacetilación heterogénea logró generar quitosano de alto peso molecular, así como mantener la cristalinidad a pesar del fuerte tratamiento químico utilizado durante la desacetilación.

Por lo anterior, se probó que el uso de métodos biológicos para el tratamiento de desperdicio de camarón; como es la inoculación de microorganismos, son efectivos para la extracción de quitina altamente purificada, además de permitir la obtención de hidrolizados proteicos y pigmentos como la astaxantina, que son de interés industrial. Así mismo se probó que es posible obtener nanofibrillas de quitina y quitosano de alto peso molecular a partir de la quitina extraída por métodos biológicos; aunado a la posibilidad de obtener un lote mayor de quitina mediante inoculación sucesiva generando los mismos resultados. 


\section{REVISIÓN BIBLIOGRÁFICA}

\section{REVISIÓN BIBLIOGRÁFICA}

\subsection{Quitina}

La quitina es un biopolímero compuesto por residuos de $N$-acetil-D-glucosamina (DGlcNAc) y $N$ - glucosamina (D-GlcN) unidos por enlaces $\beta$ - $(1,4)$ siendo la D-GlcNac el principal componente en la cadena. La quitina es el componente estructural del exoesqueleto de insectos, crustáceos y en menores proporciones de la pared celular de hongos y algas, por lo que la fuente principal de obtención de quitina son los desechos de crustáceos, como el cangrejo y el camarón, de los cuáles entre el $20 \%$ y el $50 \%$ de peso seco corresponde a este biopolímero (Kurita, 2001). La quitina tiene entre sus características el ser cristalina además de encontrarse en tres formas cristalográficas que son: $\alpha$-, $\beta$ - y $\gamma$-, siendo la $\alpha$-quitina la isoforma más abundante, donde la quitina esta compactada en una estructura cristalina con cadenas antiparalelas, lo que favorece la formación de puentes de hidrógeno y con esto se incrementa la cristalinidad (Kurita, 2001). La $\beta$-quitina, encontrada comúnmente en calamares, tiene una fuerza intermolecular más débil que la $\alpha$-quitina debido a que su arreglo es paralelo, lo que ocasiona menor estabilidad. La $\gamma$-quitina es una mezcla de las dos isoformas de quitina

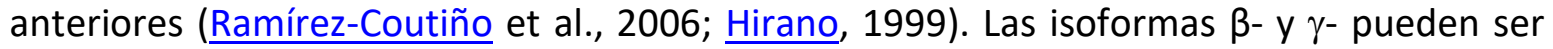
transformadas en $\alpha$-quitina al ser diluidas o extraídas mediante el uso de ácidos (Kurita, 2001).

\subsection{Quitosano}

El quitosano, derivado desacetilado de la quitina está formado de residuos de $\mathrm{N}$ glucosamina (D-GlcN) y $N$-acetil-D-glucosamina (D-GlcNAc) unidos por enlaces glicosídicos $\beta-(1,4)$. Al contrario de la quitina, los residuos de $D-G \mid c N$ se encuentran en mayor proporción (al menos 50\%) en el quitosano. El quitosano no es tan común en la naturaleza, encontrándose como tal en las paredes celulares de algunos hongos, por lo que su producción se realiza comúnmente a través de la desacetilación química de la quitina, en la cual se sustituyen los grupos acetamido por grupos amino. Lo que genera 
REVISIÓN BIBLIOGRÁFICA

que el quitosano presente carga positiva y por lo tanto tenga la propiedad de atrapar moléculas con carga negativa como lípidos, proteínas y minerales. Esta cualidad, junto con el peso molecular (PM) y el grado de acetilación (DA), correspondiente a la fracción de residuos de D-GlcN presentes en la cadena, son características que determinan las posibles aplicaciones del quitosano (Lamarque et al., 2004).

\subsection{Aspectos estructurales de quitina y quitosano}

En los artrópodos, así como en la pared celular de hongos y las levaduras, la quitina se encuentra en un arreglo de microfibrillas cristalinas formando los componentes estructurales del exoesqueleto (Pillai et al., 2009). En los crustáceos (Fig. 1), la quitina se encuentra formando microfibras, las cuales se conforman de nanofibrillas de $200 \mathrm{~nm}$ de longitud y 3-5 nm de ancho, entrelazadas en una matriz de carbonato de calcio y proteínas (Ifuku et al., 2009).

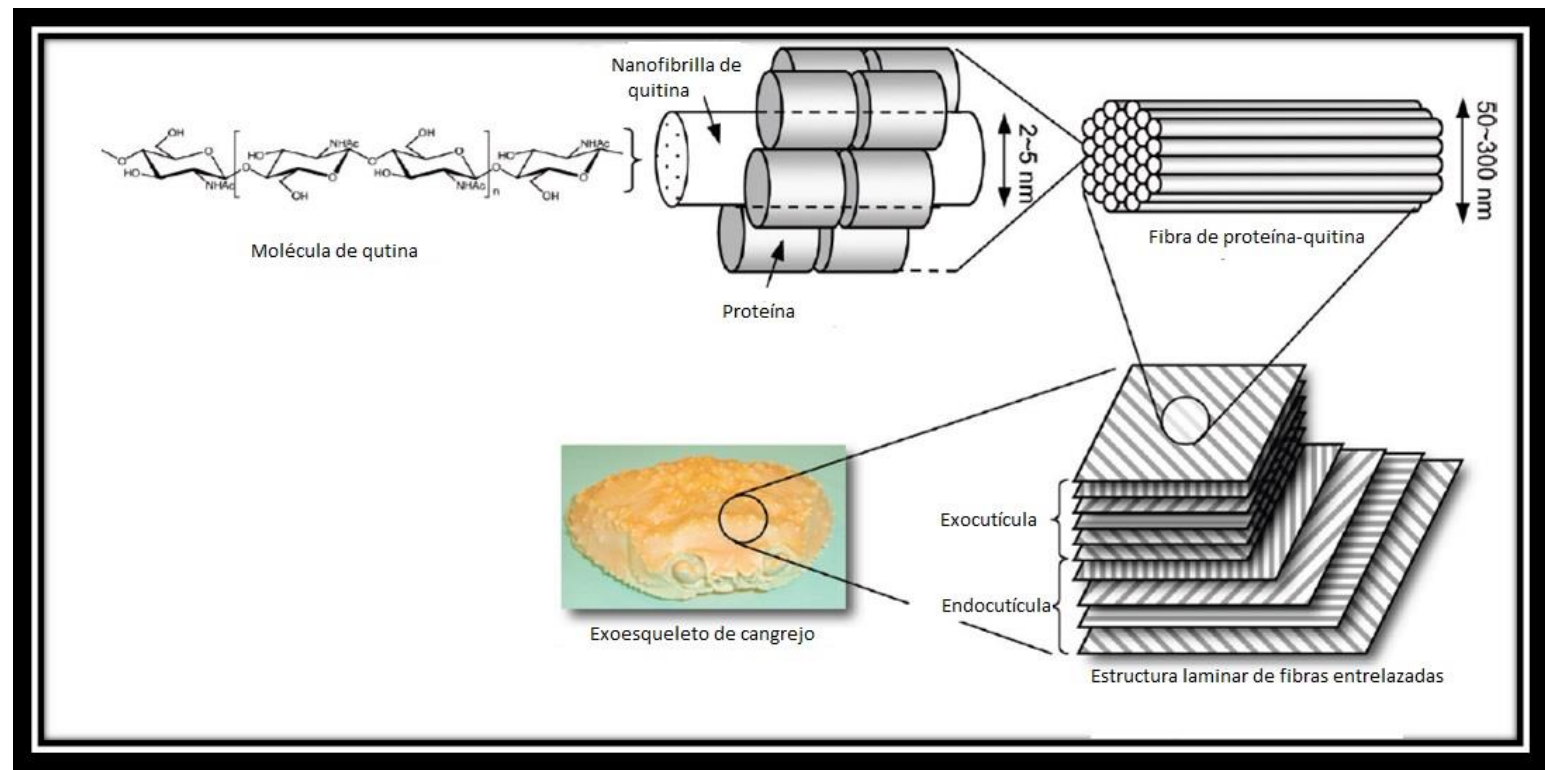

Fig. 1. Fibras de quitina en exoesqueleto de crustáceos.

(Ifuku et al, 2009) 


\section{REVISIÓN BIBLIOGRÁFICA}

Debido a su estructura lineal y a la presencia de un grupo acetamida y dos grupos hidroxilo, la quitina procedente de crustáceos es altamente cristalina con fuertes puentes de hidrógeno y las microfibrillas están arregladas de forma antiparalela (Ifuku et al., 2009). El grado de acetilación (DA) común en la quitina es de $90 \%$ o superior, lo que indica la presencia de algunos grupos amino, que pueden deberse al proceso de extracción o como tal a la fuente de la quitina. EI DA es un parámetro que define la solubilidad de la quitina, ya que mientras menor sea el grado de DA mayor será la solubilidad en soluciones acuosas ácidas (Pillai et al., 2009).

La estructura de la quitina es similar a la de la celulosa, con la diferencia de que la quitina cuenta con grupos acetamido en C-2 en lugar de grupos hidroxilo. A su vez, la presencia de algunos grupos amino le confiere ventajas relacionadas con diversas funciones biológicas y reacciones modificantes (Kurita, 2001).

El quitosano es un polisacárido catiónico lineal, que al ser obtenido principalmente de la $N$-desacetilación de la quitina, tiene la misma estructura, pero sustituyendo los grupos acetamida por grupos amino, presentando distintas proporciones de cadenas acetiladas y desacetiladas (Fig. 2). Es cristalino, y al igual que la quitina muestra polimorfismo con base en su estado físico. El DA del quitosano es más bajo que el de la quitina, lo que lo hace soluble en ácido clorhídrico y ácidos orgánicos (Kurita, 2001).

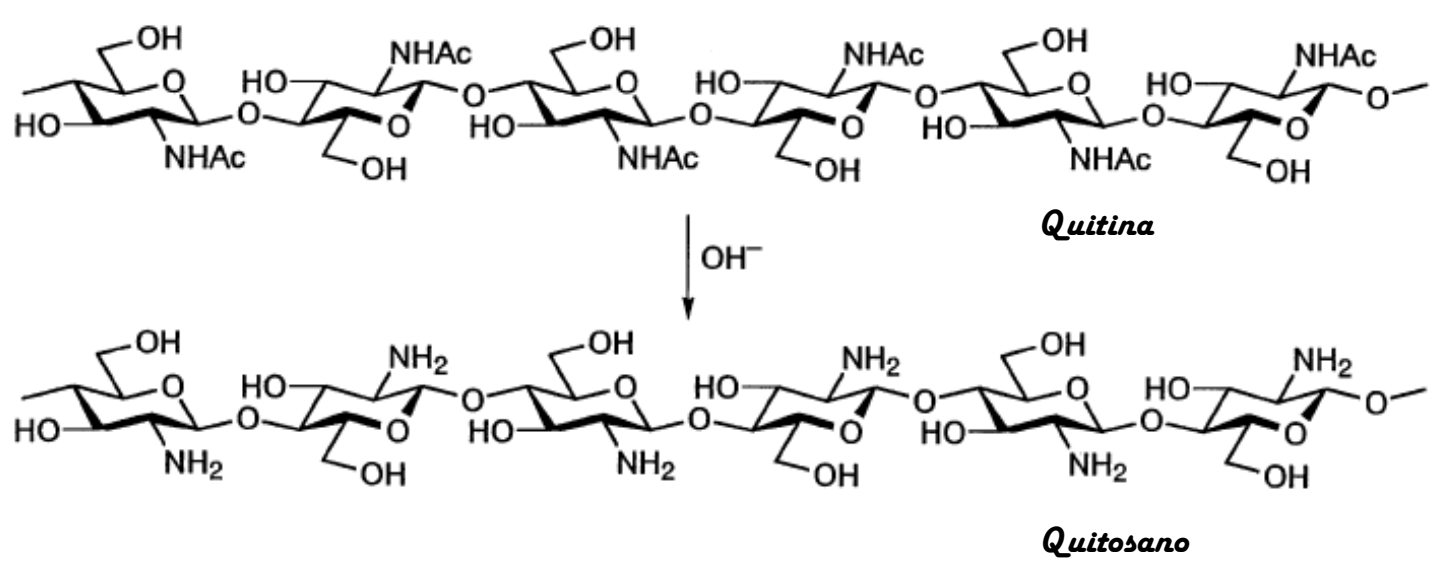

Fig. 2. Estructura molecular de la quitina y quitosano.

(Kurita, 2001) 


\subsection{Cutículla de crustáceos y sus componentes.}

La quitina comercial ( $\alpha$-quitina) se obtiene principalmente de los exoesqueletos de camarón y cangrejo, donde la quitina esta unida a carbonato de calcio $\left(\mathrm{CaCO}_{3}\right)$, proteínas, grasa y pigmentos.

\subsubsection{Exoesqueleto de crustáceos}

El exoesqueleto o cutícula es la última capa presente en el cuerpo de crustáceos, es la encargada de brindar soporte y proteger los órganos internos. Puede dividirse a su vez en tres capas: epicutícula, exocutícula y endocutícula. La primera capa es la más superficial y se encuentra ligada a ácidos grasos o ésteres y alcoholes. Son la exo- y la endocutícula las que presentan la mayor concentración de microfibras de quitina, capas en las cuales la quitina está ligada a las proteínas y los minerales (Fig. 3). El grosor de las diversas capas de la cutícula dependerá de la especie de crustáceo, siendo más gruesa en cangrejos y langostas que en camarones (Raabe et al., 2006; Taylor et al., 2015)

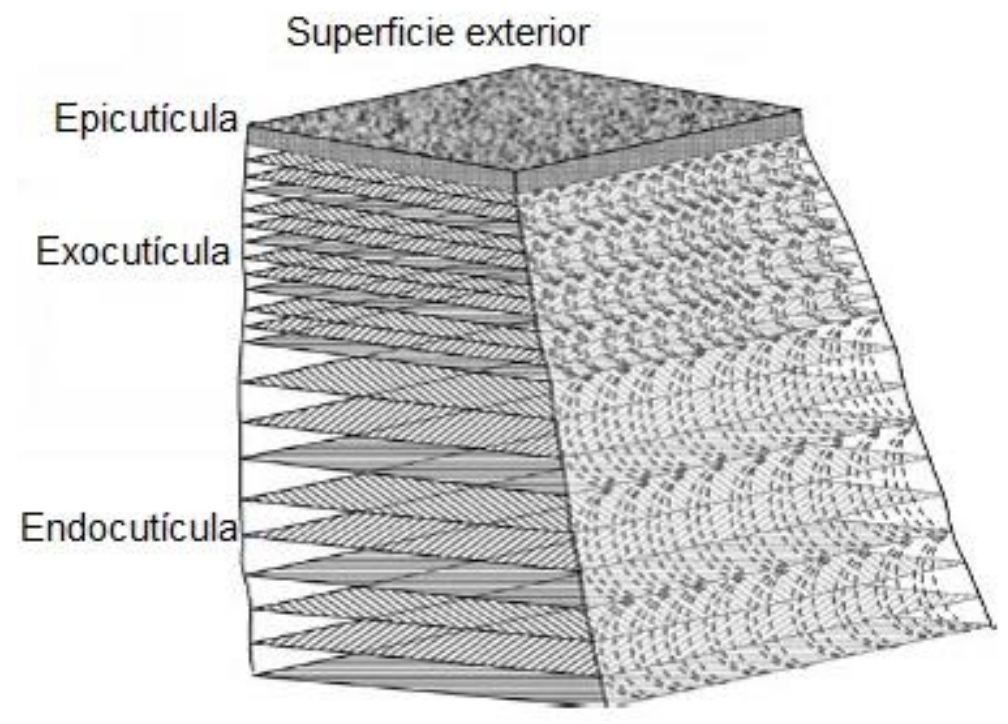

Fig. 3. Capas presentes en la cutícula de langosta Homarus americanus (Raabe et al., 2006). 


\section{REVISIÓN BIBLIOGRÁFICA}

\subsubsection{Proteína, minerales y pigmentos en crustáceos}

Los desechos de cangrejo y camarón pueden emplearse para la extracción de quitina, siendo este último el que puede presentar mayor porcentaje de proteína (Hajji et al., 2014). La proteína del músculo de camarón puede ser dividida en tres grupos: sarcoplásmica que está localizada en la región intersticial entre las fibras individuales del músculo, miofibrilar comúnmente encontrada en la fibra muscular, y estromal que se asocia al tejido conectivo (Niamnuy et al., 2008). Las proteínas sarcoplásmicas y miofibrilares son solubles en soluciones iónicas mientras que las estromales son solubles en soluciones de hidróxido de sodio $(\mathrm{NaOH})$, siendo estas últimas las más difíciles de remover aún con varios ciclos de álcali obteniendo quitina con proteína residual (Mayren, 2013).

Los minerales pueden encontrarse $\mathrm{como}^{\mathrm{CaCO}} 3$ cristalino (calcita), aunque partículas amorfas pueden presentarse dependiendo de la especie o el ciclo de muda en el que se encuentre, ya que durante la muda el $\mathrm{CaCO}_{3}$ amorfo es almacenado pues se necesita para endurecer la cutícula (Luquet y Marin, 2004; Raabe et al., 2005). El $\mathrm{CaCO}_{3}$ se presenta como aragonita, vaterita y calcita (Zhang et al., 2012), donde los dos primeros polimorfos, junto con el $\mathrm{CaCO}_{3}$ en estado amorfo, son formas inestables y pueden reaccionar fácilmente en medio acuoso para convertirse en calcita, que es más estable. El cobre, manganeso, zinc, hierro, sodio y magnesio también pueden estar presentes (Hajji et al., 2014), siendo este último un estabilizante para el $\mathrm{CaCO}_{3}$ amorfo evitando su transformación en calcita (Zhang et al., 2012).

Dentro de los pigmentos (carotenoides) presentes en crustáceos como el camarón, el más abundante es la astaxantina, presente en un 70-99\%. Se encuentra comúnmente ligada a ésteres, proteínas (carotenoproteínas) o lipoproteínas (carotenolipoproteínas). Otros pigmentos que pueden encontrarse son luteína, zeaxantina y astaceno. Los carotenoides se acumulan tanto en los tejidos como en el exoesqueleto de los crustáceos, los cuales son asimilados mediante la ingesta, ya que no pueden ser sintetizados por ellos mismos (Higuera-Ciapara et al., 2006). Los pigmentos tienen importancia industrial ya que son 


\section{REVISIÓN BIBLIOGRÁFICA}

utilizados como colorantes, alimento para especies como el salmón y como nutracéutico debido a su alta actividad antioxidante. (Goswami et al., 2010)

\subsection{Métodos de obtención de quitina}

Debido a que la quitina en la cutícula de crustáceos se encuentra ligada a las fracciones de proteína, minerales y pigmentos, es necesaria su purificación, la cual puede llevarse a cabo por diversos tipos de tratamientos entre los que destaca el uso de compuestos químicos y los procesos biotecnológicos como la fermentación/cultivo con microorganismos o el uso de enzimas.

\subsubsection{Método químico}

El tratamiento químico se basa en la utilización de ácidos y bases fuertes para la desmineralización y desproteinización de los desperdicios, lo que permite la obtención de la quitina pura. En el proceso de desmineralización, el $\mathrm{CaCO}_{3}$ es removido mediante su reacción con ácido clorhídrico $(\mathrm{HCl})$ (aunque otros ácidos como el ácido sulfúrico, el ácido acético o el ácido nítrico pueden ser utilizados). La reacción se basa en la disociación del $\mathrm{CaCO}_{3}$ para formar cloruro de sodio $\left(\mathrm{CaCl}_{2}\right)$, una sal soluble en agua, junto con la liberación de dióxido de carbono $\left(\mathrm{CO}_{2}\right)$, lo que provoca formación de espuma. Una vez que el calcio se encuentra como una sal soluble, puede ser retirado mediante filtración del sólido y un lavado posterior con agua desionizada. El porcentaje de desmineralización (DM) depende de la cantidad de minerales originales en los desechos, por lo que comúnmente se utilizan altas concentraciones de ácido o en proporción mayor a la estequiométricamente necesaria. Investigaciones previas indican que la utilización de ácido a alta temperatura o por largo tiempo promueve la introducción del solvente en la matriz de quitina. Para desproteinizar, el hidróxido de sodio $(\mathrm{NaOH})$ o potasio $(\mathrm{KOH})$ son los más utilizados. La desproteinización (DP) resulta difícil de realizar debido al enlace químico de la proteína con la quitina, pero es de suma importancia para las posibles aplicaciones de la quitina, ya que gran parte de la población presenta alergias a las proteínas presentes en los mariscos. Al igual que el proceso de desmineralización, la 


\section{REVISIÓN BIBLIOGRÁFICA}

desproteinización puede llevarse a cabo a altas temperaturas o periodos largos de tiempo. Se recomienda iniciar la purificación de la quitina desmineralizando, ya que al encontrarse los minerales formando capas entra las fibras se puede evitar la introducción del álcali para la remoción de la proteína unida a la quitina (Younes y Rinaudo, 2015). Como método de purificación alterno, puede llevarse a cabo la extracción de pigmentos con solventes como el metanol o la acetona, o bien a través de un blanqueado mediante peróxido de hidrógeno o hipoclorito de sodio. La desventaja de los métodos químicos radica en la pérdida de propiedades funcionales de la quitina, como la disminución del PM, cristalinidad, y el impedimento de la obtención de otros productos de valor agregado en los desperdicios, como proteínas y pigmentos con alta actividad antioxidante.

\subsubsection{Cultivo con microorganismos}

Otro procedimiento para la purificación de la quitina es la inoculación de microorganismos en los desechos de crustáceos, entre los que destacan las bacterias pertenecientes a Lactobacillus, Bacillus, Pseudomonas y Serratia (Shirai et al., 2001; Cira et al., 2002; Jung et al., 2006).

La fermentación es un proceso de conservación en el cual los ácidos adicionados o producidos inhiben el crecimiento de patógenos. En la purificación de quitina, los microorganismos fermentadores utilizados secretan ácidos orgánicos que disminuyen el $\mathrm{pH}$, impidiendo la proliferación de otros microorganismos, y contribuyen a la solubilización de minerales in situ, como el $\mathrm{CaCO}_{3}$, y a la desproteinización mediante su producción de enzimas. La fermentación ácido láctica (FAL) empleando bacterias lácticas como Lactobacillus plantarum, ha sido previamente reportada y utilizada exitosamente para la desmineralización de desechos de camarón (Shirai et al., 2001; $\underline{\text { Cira }}$ et al., 2002). También se utilizan microorganismos que, a pesar de no ser fermentadores, tienen una fuerte actividad proteolítica. En algunos casos, la utilización de microorganismos fermentadores junto con microorganismos proteolíticos permite facilitar la extracción de la quitina y contribuir a la sustitución de los métodos químicos (Jung et al., 2006). 


\section{REVISIÓN BIBLIOGRÁFICA}

Los microorganismos utilizados para la fermentación son principalmente bacterias, debido a su capacidad fermentadora y alta producción de ácidos orgánicos (Mao et al., 2013). Sin embargo, son pocas las bacterias que presentan alta actividad proteolítica, lo que dificulta obtener un alto grado de desproteinización en el ensilado, por lo que la utilización de hongos altamente proteolíticos, que a su vez generen altas concentraciones de ácidos orgánicos, se ha vuelto una alternativa novedosa para la extracción de quitina.

Por otra parte, los procesos de co-fermentación para la obtención de quitina han sido estudiados con dos tipos de bacterias, una fermentadora y otra con actividad proteolítica (Jung et al., 2006); así como la acción de distintos tipos de hongos altamente proteolíticos y generadores de ácidos orgánicos como los del género Rhizopus (Huang et al., 2003; Phrueksawan et al., 2012), ya sea como único microorganismo o en combinación con bacterias lácticas.

También hay que tomar en cuenta que para la utilización de microorganismos fermentadores, es necesaria una fuente de carbono, puesto que el camarón cuenta con baja cantidad de carbohidratos fermentables para iniciación del cultivo (Cira et al., 2002; Shirai et al., 2001), por esto se utilizan fuentes de carbohidratos como glucosa, sacarosa o melazas; procurando que sean fuentes económicas y accesibles.

La ventaja de estos procedimientos biológicos es la reducción de residuos químicos, el mantenimiento de las características estructurales del biopolímero y la posibilidad de obtener otros productos, como hidrolizados proteicos y ácidos orgánicos; sin embargo, requiere la inversión de largos periodos de tiempo en comparación con los métodos químicos que pueden requerir solamente horas.

\subsubsection{Desproteinización enzimática}

Otro tipo de tratamiento biológico es la utilización de enzimas para lograr la desproteinización de los desechos de crustáceos, ya sea utilizando enzimas comerciales (Juárez, 2012; Mayren, 2013) o aisladas de cultivo de microorganismos (Younes et al., 2012). Las proteasas son enzimas capaces de hidrolizar enlaces peptídicos. Este tipo de enzimas puede actuar en los extremos de la cadena polipeptídica o dentro de la misma 


\section{REVISIÓN BIBLIOGRÁFICA}

(exopeptidasas y endopeptidasas, respectivamente) (Palma et al., 2002). Las proteasas que se producen comercialmente tienen gran cantidad de usos, que van desde el tratamiento de alimentos (carnes, lácteos, cerveza), aplicaciones farmacéuticas, detergentes industriales, elaboración de lana y cuero, entre otros, por lo que su producción es la principal en el mercado en comparación con otros tipos de enzimas (González-Rábade et al., 2011).

La acción y aplicación de enzimas en general depende de distintos factores, como son el $\mathrm{pH}$, la temperatura y la concentración de enzima.

La base de datos MEROPS considera siete familias de proteasas: Aspartato, Cisteina, Glutámico, Metalo, Asparagina, Serina y Treonina (Rawlings y Barrete, 2010).

Las proteasas de grado alimenticio, usadas principalmente por el tipo de aplicación al que van dirigidas, pueden clasificarse dependiendo de su origen (animal, vegetal, bacteriano o fúngico), el lugar dónde realizan la acción catalítica o con base en su sitio catalítico. Las proteasas comerciales pueden venderse de manera individual o como preparado enzimático, el cual es una combinación de varias enzimas (Benítez et al., 2008).

La hidrólisis enzimática se compone de tres reacciones simultáneas de ruptura de enlaces. Primero se forma un complejo enzima-sustrato (proteína) y después se lleva a cabo la ruptura del enlace peptídico dando como resultado la liberación de un péptido. Por último, el péptido resultante se separa de la enzima después de un ataque nucleofílico de una molécula de agua (Benítez et al., 2008). Por esto, la hidrólisis enzimática mediante el uso de enzimas comerciales es una de las opciones para la desproteinización del desecho de camarón para la obtención de quitina.

En comparación con el uso de microorganismos, la desproteinización enzimática requiere menos tiempo; sin embargo, requiere la utilización de ácidos para la eliminación de los minerales. 


\section{REVISIÓN BIBLIOGRÁFICA}

\subsection{Obtención de nanofibrillas de quitina}

A pesar de los distintos métodos de obtención de quitina a partir de desechos de crustáceos, la estructura original de microfibras permanece sin cambios debido a los puentes de hidrogeno intra- e intermoleculares, complicando así la solubilidad de la quitina y sus posibles aplicaciones. Por lo anterior, la fibrilación de la quitina para la obtención de nanofibrillas mejora las posibles aplicaciones de la quitina. Para la obtención de estas nanofibrillas, varios métodos pueden ser empleados como son: electrospinning, hidrólisis ácida, ultrasonicación, TEMPO-oxidación y tratamientos mecánicos como la molienda y el choque mecánico de quitina mediante alta presión, siendo estos últimos los más efectivos para la obtención de nanofibrillas de 10-20 nm de grosor (Ifuku et al., 2009). Las nanofibrillas de quitina pueden ser fácilmente dispersadas en agua, secadas para formar películas o modificadas superficialmente para mejorar su afinidad a otras sustancias, ampliando así la gama de aplicaciones, que se veían limitadas por la baja solubilidad del biopolímero (Ifuku y Saimoto, 2012).

\subsection{Obtención de quitosano}

El quitosano se obtiene comúnmente mediante la desacetilación química de la quitina con álcalis fuertes, como $\mathrm{NaOH} \circ \mathrm{KOH}$ a temperatura ambiente y tiempos largos (desacetilación homogénea) o puede ser a altas temperaturas y periodos de tiempo cortos (desacetilación heterogénea). Sin embargo, en ambos procedimientos la desacetilación no es completa a lo largo de las cadenas de quitina, ya que el biopolímero es semicristalino y el acceso a los sitios reactivos es limitado en la parte cristalina. Con base en esto, así como la fuente de quitina de dónde se obtenga, el DA y PM del quitosano varían con cada lote. El DA del quitosano comercial se encuentra entre $30 \%$ y $5 \%$, y el PM entre $10^{4}-10^{6} \mathrm{gmol}^{-1}$ (Motta de Moura et al., 2011), siendo estas dos características las que generalmente afectan la posible aplicación del quitosano. También hay que tomar en cuenta que mientras mayor sea la concentración de álcali y el tiempo de reacción, el peso molecular del quitosano tiende a disminuir mientras que el grado de desacetilación aumenta (Yuan et al., 2011). 


\section{REVISIÓN BIBLIOGRÁFICA}

Otros procedimientos para la obtención de quitosano son el uso de enzimas que lleven a cabo la reacción de desacetilación, ya sea utilizando enzimas comerciales o extraídas de algún microorganismo ( $\underline{\text { Pachecho }}$ et al., 2013), así como la obtención directa del quitosano presente en la pared celular de hongos (Jiang et al., 2011). 


\section{ANTECEDENTES}

La obtención alternativa de quitina mediante métodos biológicos ha tomado importancia, ya que presenta más ventajas que la extracción química, puesto que no hay degradación del polímero, el rendimiento es mayor y es posible obtener productos de valor agregado, además de disminuir la contaminación ambiental al evitar el uso de sustancias químicas.

\subsection{Culltivo con microorganismos para obtención biológica de quitina.}

La inoculación de microorganismos generadores de ácidos orgánicos en los desperdicios de crustáceos es un método de purificación de quitina previamente estudiado, como fue reportado en 2001 por Shirai y colaboradores, quienes probaron diversas variables utilizando bacterias lácticas para la FAL, con el fin de incrementar los porcentajes de DM y DP en desechos de camarón. Las variables fueron el tipo de bacteria láctica a inocular, el nivel de inóculo y concentración de glucosa añadida inicialmente como fuente de carbono. Los investigadores obtuvieron que una concentración de Lactobacillus sp. B2 al 5\% y una concentración de glucosa al 10\% resulta en mayor remoción de proteína y minerales. Posteriormente, en 2002, Cira y colaboradores probaron distintos tipos de fuentes de carbono para la FAL sobre desechos de camarón utilizando la misma bacteria, obteniendo que la sacarosa puede utilizarse como fuente de carbono al igual que la glucosa. Por otra parte, en una fermentación con inoculación sucesiva de dos microorganismos, en 2006 Jung y colaboradores utilizaron Lactobacillus paracasei sub. tolerans y Serratia marcensces sobre desechos de camarón con la finalidad de que la primera cepa generará ácido láctico para la desmineralización del desecho y la segunda contribuyera a la desproteinización del mismo. Se observó que el empleo de ambos microorganismos generó mayores porcentajes de DM y DP en comparación con el uso de cada bacteria como único microorganismo. En 2009, Pacheco y colaboradores estudiaron el efecto de la temperatura sobre la FAL en desechos de camarón mediante el uso de Lactobacillus plantarum para la obtención de quitina y astaxantina, encontrando que entre $30^{\circ} \mathrm{C}$ y $40^{\circ} \mathrm{C}$ 
ANTECEDENTES

se obtuvo el menor porcentaje de proteína y minerales con el mayor rendimiento de quitina. En cuanto a la astaxantina, la temperatura óptima fue entre $20^{\circ} \mathrm{C}$ y $30^{\circ} \mathrm{C}$, considerando que mientras la temperatura aumenta, la concentración de astaxantina libre disminuye y aumenta la concentración de su cis-isómero. Por lo anterior determinaron que el mayor rendimiento de quitina y concentración de astaxantina se obtiene a los $30^{\circ} \mathrm{C}$. Continuando con esa investigación, en 2011 Pacheco y colaboradores compararon las características de quitinas obtenidas químicamente y mediante FAL a partir de desechos de camarón; mostrando que la quitina obtenida mediante FAL presenta mayor PM y cristalinidad, aunado a la obtención de astaxantina en las fracciones sólidas y líquidas, siendo la primera fracción la que presentó mayor concentración del pigmento. En el trabajo de Flores-Albino y colaboradores en 2012, se utilizó una especie de Lactobacillus sobre desechos de cangrejo, añadiendo melazas de caña de azúcar como fuente de carbono, obteniendo que el mayor rendimiento de quitina se alcanzó con $50 \mathrm{~g} / \mathrm{L}$ de melaza y $100 \mathrm{~g} / \mathrm{L}$ de desperdicios de cangrejo. Por su parte, Ghorbel-Bellaaj y colaboradores en el mismo año, utilizaron distintas especies de Bacillus (B. cereus, $B$. subtillis, B. mojavencis, B. pumilus, B. licheniformis y B. amyloliquefaciens) conocidas por su alta producción de proteasas, para la remoción de minerales y proteína de desechos de camarón, obteniendo que la inoculación de la cepa de $B$. cereus resultó en mayores porcentajes de DM y DP; además de destacar la alta actividad antioxidante presente en la fracción líquida obtenida del proceso fermentativo. En otra investigación, Mao y colaboradores en 2013 utilizaron a Streptococcus thermophilus para la obtención de antioxidantes y recuperación de quitina de desechos de camarón, obteniendo que, al aumentar el tiempo de fermentación, también aumentaba la capacidad antioxidante y concentración de astaxantina en la fracción líquida.

Las investigaciones anteriores utilizan cómo únicos microorganismos a diferentes especies de bacterias, ya sea por su alta producción de ácidos orgánicos o por su alta producción de proteasas; sin embargo, otros tipo de microorganismos, como los hongos, también pueden ser utilizados para la obtención de quitina, siempre y cuando tengan algunas de las características necesarias, es decir que generen ácidos que contribuyan a la 
ANTECEDENTES

desmineralización in situ del desecho, produzcan una alta cantidad de enzimas proteolíticas y tengan baja actividad de quitinasas para evitar la ruptura del polímero. Se ha reportado que Rhizopus oligosporus posee alta actividad proteolítica, baja actividad quitinolítica y alta producción de ácidos orgánicos por lo que resultó ser un microorganismo adecuado para la obtención biológica de quitina, ya que en contraste con los ensilados con bacterias, que tardan entre 120 y $144 \mathrm{~h}$ de tiempo de cultivo, Rhizopus oligosporus generó altos porcentajes de desmineralización y desproteinización en 96 h (Aranday-García, 2013).

\subsection{Desproteinización enzimática para la obtención de quitina}

Otro procedimiento para la extracción de quitina consiste en el uso de enzimas para desproteinizar el desperdicio de camarón. Estas enzimas pueden ser de origen comercial,

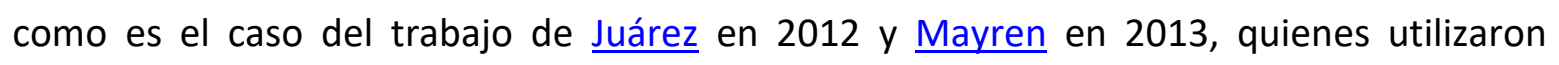
enzimas como Deterzyme ${ }^{\circledR}$, Protamex $^{\circledR}$ y Alcalasa ${ }^{\circledR}$ para llevar a cabo la desproteinización. El uso de estas enzimas puede combinarse con fermentación, realizando la extracción de quitina mediante fermentación con Lactobacillus spp. B2 y el uso posterior de enzimas (Juárez, 2012). También puede combinarse con soluciones buffer que promueven la remoción de proteína y facilitan así la acción de las enzimas sobre la proteína restante, como lo reportó Mayren quién realizó un pretratamiento del desperdicio de camarón con soluciones buffer y posteriormente aplicó las enzimas comerciales.

Otra forma de utilizar las enzimas es purificándolas del cultivo de microorganismos con alta producción de proteasas, como lo fue en el trabajo de Younes y colaboradores en 2012, quienes realizaron distintos cultivos de Bacillus, Vibrio metschnikovii y Aspergillus clavatus, y utilizaron los medios de cultivo dónde se encontraban los microorganismos para determinar la actividad de las enzimas contenidas y así aplicarlas al desecho de camarón, obteniendo que el medio que contenía proteasas de Bacillus mojavensis presentó mejores resultados. Ésta última bacteria fue también utilizada por Hajii y colaboradores en 2014 para obtener un enzimado crudo, el cual fue empleado a pH 9 y 
ANTECEDENTES

$50^{\circ} \mathrm{C}$ sobre desperdicios de camarón, cangrejo y calamar desmineralizados químicamente, obteniendo una desproteinización de hasta de $88 \%$ con una proporción de enzima/sustrato de 20 . El hecho de que no se lograra el $100 \%$ de desproteinización es atribuido a la imposibilidad de las enzimas de acceder a la proteína ligada a la quitina.

\subsection{Obtención de quitina como nanofibrillas}

La obtención de quitina puede también llevarse a cabo mediante la fibrilación para la

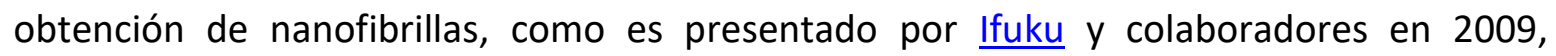
quienes después de desproteinizar y desmineralizar el desecho de cangrejos con soluciones de $\mathrm{NaOH}$ y $\mathrm{HCl}$ respectivamente, mezclaron la quitina cruda en una solución acuosa con $1 \%$ de quitina y ácido acético para ajustar el pH a 3. Posteriormente colocaron la mezcla en un molino especial a 1,500 rpm, logrando así una separación óptima de las nanofibrillas de quitina de la matriz en que se encuentran embebidas; para lo cual hace notar que la quitina molida debe permanecer húmeda para evitar la formación de puentes de hidrógeno y lograr así la separación. Posteriormente, Ifuku y Saimoto, en 2012, realizaron el mismo procedimiento para la obtención de nanofibrillas de quitina de diversos tipos de cangrejos y hongos, obteniendo también una separación de la matriz de proteína o glucanos respectivamente, aunque con remanencia de algunos glucanos en el caso de las nanofibrillas de hongos. Las nanofibrillas obtenidas fueron utilizadas para diferentes funciones, como fue la obtención de nanocompuestos ópticamente transparentes, membranas de separación quiral, y la funcionalización de las nanofibrillas para tratar inflamación intestinal. En el mismo año, Ifuku y colaboradores obtuvieron nanofibrillas mediante otro tratamiento mecánico utilizando quitina comercial, la cual fue nuevamente dispersada en agua ácida. La dispersión fue licuada convencionalmente y posteriormente pasada a través de un equipo que colisiona la dispersión con bolas de cerámica a través de una apertura de $100 \mu \mathrm{m}$ utilizando agua a alta presión (245 MPa). Este procedimiento resultó en la obtención de un mayor volumen de nanofibrillas que las obtenidas mediante molienda, resaltando nuevamente la necesidad de mantener las 
condiciones ácidas para asegurar la completa fibrilación de la quitina y comprobando que aun cuando la quitina se encuentre seca, puede ser fibrilada por tratamiento mecánico, eliminando así la necesidad de mantener el biopolímero en estado húmedo.

\subsection{Obtención de quitosano mediante desacetilación de quitina}

Una vez que se obtienen las hojuelas de quitina, independientemente del procedimiento empleado, la desacetilación a quitosano suele ser agresiva por el uso de álcalis fuertes (entre 40 y 70\%) además de que el tiempo necesario suele ser largo llegando a abarcar días. Las características del quitosano obtenido pueden variar con el lote, pero comúnmente se obtiene un biopolímero de bajo peso molecular, y mientras mayor sea el grado de acetilación que se deseé alcanzar, menor será el peso molecular obtenido. Yaghobi y Mirzadeh en 2004, utilizaron una atmósfera de nitrógeno para la desacetilación química, probando tiempos de reacción largos en continuo o en lote, obteniendo mejores resultados al hacerlo por etapas en intervalos menores de tiempo hasta igualar el tiempo de una desacetilación larga continua. Trabajos como el de Yuan y colaboradores en 2011, buscaron modificar la desacetilación química investigando distintos intervalos de tiempo y concentraciones de álcali utilizando también una atmósfera de nitrógeno con el fin de obtener un material adecuado para el uso biomédico; obteniendo que el crecimiento de células óseas fue mayor al utilizar quitosano con bajo DA a pesar de la disminución del PM del quitosano.

Las características del quitosano, como son el PM y el DA, repercuten en la posible aplicación del quitosano, principalmente en ámbitos médicos y farmacéuticos. Kumar menciona en el 2000 la utilización de quitosano y alginato para encapsular hemoglobina, observando que mientras mayor sea el PM, la retención será mayor. Por otra parte, Honary y colaboradores en el 2009 utilizan nuevamente quitosano y alginato para la producción de micropartículas para mejorar la tasa de liberación de medicamentos, llegando a la misma conclusión que Kumar, pues la tasa de liberación es más lenta al aumentar el PM del quitosano. En otra investigación, Bof y colaboradores en 2015 
ANTECEDENTES

investigan el uso de almidón de maíz y quitosano para la elaboración de películas biodegradables, encontrando nuevamente que la resistencia de las películas aumenta al aumentar el PM del quitosano. El quitosano de PM alto fue igualmente el que presentó mejores características en el trabajo de Li y colaboradores en 2016, quienes obtuvieron quitosano de $\beta$-quitina y estudiaron sus propiedades antibacterianas, las cuales aumentaron con el PM del quitosano.

Las investigaciones descritas anteriormente presentan las ventajas de utilizar métodos biológicos para la obtención de quitina de desechos de camarón, así como su desacetilación a quitosano o la obtención de nanofibrillas de quitina, remarcando que, en cada caso, el biopolímero obtenido presenta distintas características que pueden influenciar las posibles aplicaciones, extendiendo las posibilidades del uso de la quitina y derivados. 


\section{JUSTIFICACIÓN}

La extracción de quitina por método químico genera un biopolímero con peso molecular bajo debido a la degradación del polímero y la tasa de producción es menor comparada con la extracción mediante el uso de fermentación o utilización de enzimas, además de que impide la obtención de productos de valor agregado (hidrolizados proteicos, pigmentos, etc.).

Los métodos de extracción biológica de quitina permiten la conservación de la cristalinidad del biopolímero y mantienen su peso molecular ( características tienen efecto en la preparación de nanofibrillas de quitina (Ifuku et al., 2009) lo que puede facilitar la fibrilación de quitina hasta nanofibrillas y mejorar así las aplicaciones de estas en distintas áreas.

De igual forma, la quitina de alto peso molecular obtenida por purificación con métodos biológicos puede ser desacetilada químicamente para obtener quitosano. El proceso químico tendría menor efecto sobre el peso molecular del quitosano logrando también un grado de desacetilación alto, además de aumentar la tasa de rendimiento de obtención de quitosano.

Debido a que la mayor parte de las aplicaciones del quitosano se basan en su peso

molecular y grado de acetilación, el uso de quitina extraída biológicamente para la obtención de quitosano amplia su campo de aplicaciones, pues permite mantener un peso molecular y cristalinidad altos, mientras que el grado de acetilación es bajo. 


\section{MATERIALES Y MÉTODOS}

\section{HIPÓTESIS}

La extracción de quitina utilizando procedimientos biológicos mantendrá las características fisicoquímicas originales del biopolímero, facilitando la obtención de nanofibrillas de quitina y mejorando sus aplicaciones; además de permitir la obtención de quitosano de alto peso molecular mediante la desacetilación heterogénea de la quitina.

\section{OBJETIVOS}

\subsection{General}

- Obtención y caracterización de quitina extraída por método biológico, así como su utilización para la preparación de nanofibrillas y desacetilación a quitosano.

\subsection{Particulares}

- Obtención de quitina por métodos biológicos: fermentación y desproteinización enzimática.

- Caracterización de los compuestos obtenidos en el método biológico que genere porcentajes de desmineralización y desproteinización más altos (proteínas, ácidos orgánicos, pigmentos, actividad enzimática).

- Obtención de un mayor lote de quitina utilizando el método que genere porcentajes de desmineralización y desproteinización más altos.

- Obtención y caracterización de nanofibrillas de quitina extraída biológicamente.

- Preparación y caracterización de películas de nanofibrillas de quitina extraída biológicamente.

- Desacetilación de la quitina y caracterización del quitosano obtenido. 
MATERIALES Y MÉTODOS

\section{MATERIALES Y MÉTODOS}

\subsection{Primera etapa: Métodos para la obtención biológica de quitina}

\subsubsection{Desperdicios de camarón}

Los desperdicios de camarón (DC) se obtuvieron del mercado de pescados y mariscos de la Ciudad de México y fueron molidos directamente hasta obtener un tamaño de partícula aproximado de $1 \mathrm{~mm}$ y congelados a $-20^{\circ} \mathrm{C}$ hasta su uso. Posteriormente se tomaron muestras de $1 \mathrm{~g}$ para realizar un análisis qúimico proximal.

\subsubsection{Obtención de quitina}

Para la obtención biológica de quitina se probaron dos métodos: Utilización de la enzima comercial Deterzyme ${ }^{\circledR}$ para el método enzimático y cultivo con el hongo Rhizopus oligosporus y la bacteria láctica Lactobacillus brevis para el método por cultivo de microorganismos. Ambos métodos se probaron inicialmente a pequeña escala (Cultivo tipo Koji) utilizando matraces Erlenmeyer de $250 \mathrm{~mL}$ analizando los porcentajes de desmineralización y desproteinización. Posteriormente el método con mayores porcentajes fue probado sobre $8 \mathrm{Kg}$ de DC como se describe en la sección 7.2.

\subsubsection{Microorganismos}

\section{Rhizopus oligosporus}

El hongo (R) fue inoculado en placas con agar papa dextrosa (PDA) e incubado durante 5 días a $30^{\circ} \mathrm{C}$ manteniéndolo posteriormente a $4^{\circ} \mathrm{C}$. El inóculo se preparó transfiriendo asadas cargadas con el hongo en matraces Erlenmeyer con PDA, los cuales se incubaron de 5 a 7 días a $30^{\circ} \mathrm{C}$. Posteriormente, se cosecharon las esporas en una solución estéril de $0.1 \%(\mathrm{p} / \mathrm{v})$ de Tween 80 hasta obtener $1 \times 10^{8}$ esporas $/ \mathrm{mL}$.

Lactobacillus brevis

La bacteria ácido láctica (L) utilizada en este estudio fue previamente aislada de desechos de camarón (Cira et al., 2002). La cepa se mantuvo en tubos con agar Man Rogosa Sharpe (MRS) a $4^{\circ} \mathrm{C}$. El inóculo se preparó transfiriendo de 2 a 3 asadas cargadas del cultivo en caldo MRS y se incubaron a $30^{\circ} \mathrm{C}$ por $24 \mathrm{~h}$ hasta obtener $10^{9} \mathrm{UFC} / \mathrm{mL}$. 


\section{MATERIALES Y MÉTODOS}

\subsubsection{Extracción enzimática}

Los DC fueron descongelados, secados y molidos hasta obtener polvo de camarón que fue tamizado mediante malla No. $80(177 \mu \mathrm{m})$. Para facilitar la remoción de proteína, se mezcló el polvo de camarón con distintas soluciones Buffer (Tabla 1). Para la remoción de proteína sarcoplásmica se mezcló el polvo de desperdicio de camarón con una primera solución iónica (buffer A) en proporción 1:10 p/v con agitación mecánica durante 10 min a $25{ }^{\circ} \mathrm{C}$. Posteriormente fue centrifugado a $10,000 \mathrm{rpm}$ durante $15 \mathrm{~min}$ a $4{ }^{\circ} \mathrm{C}$, fue decantado y las fracciones líquidas se almacenaron en refrigeración a $4{ }^{\circ} \mathrm{C}$ para su posterior análisis. La parte sólida fue secada y para la remoción de proteína miofibrilar se mezcló con el buffer B usando las mismas proporciones y procedimientos.

El sólido obtenido de la etapa de remoción de proteína fue desmineralizado mediante una mezcla con ácido clorhídrico $0.4 \mathrm{~N}$ en proporción 1:15 p/v durante una hora con agitación mecánica a $25{ }^{\circ} \mathrm{C}$. El sustrato obtenido se neutralizó con agua corriente y se secó $40{ }^{\circ} \mathrm{C}$ durante $24 \mathrm{~h}$.

La desproteinización enzimática del sustrato resultante se llevó a cabo mediante la adición de la enzima comercial Deterzyme al $1.61 \%$ durante $4 \mathrm{~h}$ a $40^{\circ} \mathrm{C}$ con un $\mathrm{pH}$ de 7.5 , así como un enjuague posterior con agua desionizada y secado para la realización de los análisis correspondientes (Mayren, 2013).

Tabla 1. Soluciones utilizadas para la extracción enzimática de quitina

\begin{tabular}{cc}
\hline Solución & Reactivos \\
\hline Buffer A & $\mathrm{Na}_{2} \mathrm{HPO}_{4}+\mathrm{KH}_{2} \mathrm{PO}_{4} 15 \mathrm{mM}$ \\
Buffer B & Buffer A $+\mathrm{KCl} 0.45 \mathrm{M}$ \\
Desmineralización & $\mathrm{HCl} 0.5 \mathrm{~N}$ \\
Enzima & $\mathrm{H}_{3} \mathrm{PO}_{4} / \mathrm{K}_{2} \mathrm{HPO}_{4} 50 \mathrm{mM}$ \\
& $1.61 \%$ Deterzyme \\
\hline
\end{tabular}




\subsubsection{Extracción de quitina mediante cultivo con microorganismos}

Para todos los tratamientos iniciales se realizaron cultivos tipo Koji en matraces Ernlenmeyer de $250 \mathrm{~mL}$ (100 g DC), en los que se mezcló el DC con los microorganismos correspondientes y glucosa como fuente de carbono. Con base en lo reportado en un trabajo previo (Aranday-García, 2013) se hicieron inoculaciones sucesivas de la bacteria y el hongo, probando diferentes niveles de inóculo de R (Tabla 2) manteniendo constante el inóculo de $\mathrm{L}$ ( $5 \%$ de caldo MRS con $10^{9} \mathrm{UFC} / \mathrm{mL}$ ). Se añadió un total de $20 \%$ de glucosa (10\% en la inoculación de $L$ y $10 \%$ en la inoculación de R). El tiempo de cultivo de $L$ se mantuvo en $120 \mathrm{~h}$ de acuerdo con lo reportado por Shirai y colaboradores en 2001, inoculando al microorganismo inicialmente para desmineralizar el desecho de camarón y facilitar la acción de las enzimas proteolítcias. El hongo fue inocualdo a las $120 \mathrm{~h}$ una vez finalizado el tiempo de incubación de $L$, y se mantuvo durante 72 h; ya que fue reportado que en este lapso R presenta mayor actividad proteolítica (Ikasari y Mitchel, 1996). El tiempo total de incubación fue de 192 h. También se realizaron cultivos inoculados únicamente con R, igualando el tiempo total de cultivo para asegurarse que los máximos porcentajes de DM y DP son alcanzados a las $72 \mathrm{~h}$ de inoculación de R. El tratamiento que resultó con las mayores DM y DP en el tiempo final fue repetido manteniendo el cultivo tipo Koji, tomando muestras cada $24 \mathrm{~h}$ determinando el $\mathrm{pH}$ y la Acidez Total Titulable (ATT) al momento, posteriormente las muestras fueron filtradas obteniéndose una fracción líquida (licor) y una fracción sólida (quitina cruda). El licor se almacenó a $-20^{\circ} \mathrm{C}$ y la quitina cruda fue enjuagada con agua corriente hasta que el agua de enjuague fue transparente, posteriormente se secó a temperatura ambiente durante 3 días. 
MATERIALES Y MÉTODOS

Tabla 2. Diseño experimental variando nivel de inóculo de Rhizopus oligosporus.

\begin{tabular}{cccc}
\hline $\begin{array}{c}\text { Tratamiento } \\
\text { (Microorganismo) }^{+}\end{array}$ & $\begin{array}{c}\text { Tiempo } \\
\text { fermentación } \\
\text { (h) }\end{array}$ & $\begin{array}{c}\text { Inóculo } R . \\
\text { oligosporus } \\
\text { (esporas/g } \\
\text { DC) }\end{array}$ & $\begin{array}{c}\text { Inóculo } \text { L. } \\
\text { brevis } \\
\text { (\%v/p) }\end{array}$ \\
\hline $\mathrm{L}$ & 120 & 0 & 5 \\
$\mathrm{R}$ & 192 & $1 \times 10^{3}$ & 0 \\
$\mathrm{R}$ & 192 & $1 \times 10^{5}$ & 0 \\
$\mathrm{R}$ & 192 & $1 \times 10^{7}$ & 0 \\
$\mathrm{~L} / \mathrm{R}$ & $120 / 72$ & $1 \times 10^{3}$ & 5 \\
$\mathrm{~L} / \mathrm{R}$ & $120 / 72$ & $1 \times 10^{5}$ & 5 \\
$\mathrm{~L} / \mathrm{R}$ & $120 / 72$ & $1 \times 10^{7}$ & 5 \\
\hline
\end{tabular}

$+\mathrm{L}=$ Lactobacillus brevis, $\mathrm{R}=$ Rhizopus oligosporus

\subsection{Obtención de lote de quitina mayor mediante el método biológico de} extracción de quitina con mayores porcentajes de desmineralización y desproteinización.

El cultivo tipo Koji correspondiente a la inoculación de Lactobacillus brevis seguido de Rhizopus oligosporus en nivel de inóculo de $10^{7}$ esporas/g de materia húmeda y $10 \%$ de glucosa en cada inoculación fue utilizado sobre $8 \mathrm{Kg}$ de DC y colocado en un reactor de acero inoxidable con $10 \mathrm{~kg}$ de capacidad nominal y $8 \mathrm{~kg}$ de capacidad de trabajo. Las dimensiones del reactor fueron $42 \mathrm{~cm}$ de largo y $20 \mathrm{~cm}$ de diámetro interno. La incubación se mantuvo a $30^{\circ} \mathrm{C}$ durante $192 \mathrm{~h}$ totales ( $120 \mathrm{~h}$ para L. brevis y $72 \mathrm{~h}$ para $R$. oligosporus). Se tomaron muestras cada $24 \mathrm{~h}$, las cuales fueron filtradas para separar las fracciones sólidas y líquidas para análisis posteriores. Los licores fueron almacenados a $-20^{\circ} \mathrm{C}$ mientras la fracción líquida fue enjuagada con agua corriente y secada a temperatura ambiente por tres días. La muestra final (192 h) fue tratada de igual manera y la fracción sólida correspondiente a quitina calcárea fue desmineralizada con $\mathrm{HCl} 0.5 \mathrm{~N}$ en proporción 1:15 p/v durante $1 \mathrm{~h}$ a temperatura ambiente. Posteriormente fue enjuagada con agua corriente y secada a temperatura ambiente durante tres días. Una vez seca fue tratada para obtención de nanofibrillas de quitina y desacetilación a quitosano. 


\subsection{Fibrilación de hojuelas de quitina para la obtención de nanofibrillas}

\subsubsection{Materiales}

Tres tipos de quitinas fueron fibriladas para la obtención de nanofibrillas:

1) Quitina obtenida del lote mayor proveniente del proceso biológico por inoculación sucesiva de Lactobacillus brevis y Rhizopus oligosporus (LR) con proceso de blanqueado mediante peróxido de hidrógeno. Una cantidad de quitina fue nuevamente decolorada con hipoclorito de sodio (cloro doméstico) al 1.5\% (1:10 $\mathrm{p} / \mathrm{v}$ con $1 \mathrm{~h}$ de agitación) para mayor purificación.

2) Quitina obtenida mediante fermentación con Lactobacillus brevis como único microorganismo (L) a escala Planta Piloto (250 kg de DC), la cual se obtuvo añadiendo $20 \%$ de inóculo y $10 \%$ de sacarosa como fuente de carbono (muestra proporcionada por la Planta piloto de procesamiento de desperdicios orgánicos en la UAM Iztapalapa). Una cantidad fue decolorada con hipoclorito de sodio de acuerdo con el proceso mencionado en el inciso 1.

3) Quitina comercial obtenida de desechos de cangrejo mediante extracción química (Muestra comprada de Koyo Chemical Industry, Hyogo, Japón).

La fibrilación de las tres muestras de quitina se realizó con el fin de comparar las propiedades de las nanofibrillas y películas elaboradas a partir de las mismas con base en el método de extracción, comparando el uso de químicos y dos métodos biológicos basados en cultivo con microorganismos.

\subsubsection{Obtención de suspensiones de nanofibrillas de quitina}

Las hojuelas de quitina fueron molidas hasta obtener un polvo y fue agregada a una solución de ácido acético al $0.5 \%$ manteniéndola en agitación por $1 \mathrm{~h}$ hasta obtener una dispersión al 1\%. La dispersión fue posteriormente pasada dos veces por un molino

formador de dispersiones (MKCA6-3; Masuko Sangyo Co., Ltd.) a 1,500 rpm con un espacio estimado de 1.5 (correspondiente a $15 \mathrm{~mm}$ ) desde la posición cero. La posición 


\section{MATERIALES Y MÉTODOS}

fue determinada como el punto de mínimo contacto entre dos piezas (rocas). La suspensión de nanofibrillas obtenida fue agitada al vacío para remover burbujas y después fue pasada 1, 5, 10, 30, 50 y 100 veces a través de un equipo micronizador mediante agua a alta presión (Star Burst Mini, HJP-25001S, Sugino Machine Co., Ltd.) con una apertura de $100 \mu \mathrm{m}$ y presión de $245 \mathrm{MPa}$ para colisionar con una pieza de cerámica interna. Las suspensiones obtenidas fueron desgasificadas y almacenadas a temperatura ambiente $\left(25^{\circ} \mathrm{C}\right)$.

\subsubsection{Preparación de películas de nanofibrillas de quitina}

Las suspensiones de nanofibrillas fueron dispersadas en agua destilada a una concentración de fibras correspondiente al $0.1 \%(\mathrm{p} / \mathrm{v})$. Una dispersión correspondiente a cada suspensión fue sonicada mediante sonda (Branson Ultrasonics Sonifer S-250 A) por 5 min a $60 \mathrm{~Hz}$ de manera continua con $40 \%$ de amplitud, mientras que la otra permaneció sin sonicación. Posteriormente ambos tipos de dispersiones fueron filtradas mediante vacío utilizando membranas de celulosa con tamaño de poro de $1 \mu \mathrm{m}$. Una vez filtradas, las películas se elaboraron secando a presión la membrana con la dispersión filtrada a $100^{\circ} \mathrm{C}$ por $30 \mathrm{~min}$, obteniendo películas entre $40-50 \mu \mathrm{m}$ de grosor.

\subsection{Desacetilación de quitina para obtención de quitosano}

La desacetilación heterogénea de la quitina obtenida en el lote mayor de quitina fue llevada cabo en un reactor de acero inoxidable de $0.7 \mathrm{~cm}$ de grosor, $12 \mathrm{~cm}$ de diámetro interno y $26 \mathrm{~cm}$ de longitud equipado con chaqueta de calentamiento conectada a un controlador de temperatura y un agitador en la parte superior. La quitina se mezcló con $\mathrm{NaOH}$ al $50 \%$ en proporción $1: 10 \mathrm{p} / \mathrm{v}$ y fue mantenida a $100{ }^{\circ} \mathrm{C}$ por $3 \mathrm{~h}$, tomando muestras cada hora. Las muestras se enjuagaron con agua corriente hasta la neutralidad y se secaron a $40{ }^{\circ} \mathrm{C}$ por $24 \mathrm{~h}$. Una vez secas fueron molidas y almacenadas para análisis posteriores. 


\section{MATERIALES Y MÉTODOS}

\subsection{Análisis de muestras}

Cada muestra de quitina cruda obtenida se tamizó con una malla No. $40(425 \mu \mathrm{m})$ para separar la parte sólida del licor. Las quitinas crudas obtenidas (fracción sólida) fueron analizadas y posteriormente se desmineralizaron químicamente con $\mathrm{HCl}$ al $0.5 \mathrm{~N}$ (Cira et al., 2002). El análisis químico proximal, \%DM, \%DP y la caracterización de la quitina se llevaron a cabo sobre el residuo sólido de la muestra, así como del desperdicio de camarón seco. El licor obtenido del cultivo con el mejor inóculo del hongo fue caracterizado determinando $\mathrm{pH}$, Acidez Total Titulable (ATT), ácidos orgánicos (láctico, acético, oxálico, cítrico, fumárico, succínico, acético y málico), proteína soluble, actividad proteolítica y quitinolítica, pigmentos (Astaxantina) y actividad antirradicalaria mediante el radical 2,2-diphenyl-1-picrylhydrazyl (DPPH).

\subsection{1. pH y ATT}

El licor fue diluido en agua destilada en proporción 1:10 y el pH se determinó mediante un electrodo ( $\mathrm{pH}$ 210, HANNA, Italy). Para la determinación de ATT se realizó la titulación con hidróxido de sodio $(\mathrm{NaOH})$ al $0.1 \mathrm{~N}$ hasta llegar a pH 8 y se expresó como $\mathrm{mmol}$ de ácido láctico por gramo de licor mediante la ecuación 1a y $1 \mathrm{~b}$.

$$
\begin{aligned}
& \% \text { ATT }=\frac{(m l N a O H)(N N a O H)(0.09)}{\text { Peso muestra }} \times 100 \\
& \text { Ácido láctico }\left(\frac{m m o l}{g}\right)=\frac{\% \frac{\mathrm{ATT}}{100}}{90} \times 1000
\end{aligned}
$$

\subsubsection{Determinación de azúcares, ácidos orgánicos y astaxantina.}

La concentración de glucosa, ácidos orgánicos y astaxantina se determinó mediante HPLC. Los ácidos orgánicos: ácido láctico, ácido acético, ácido succínico, ácido cítrico, ácido fumárico, ácido málico y ácido oxálico, al igual que la glucosa se determinaron en un equipo Agilent 1260 infinity acoplado a un detector de índice de refracción (IR). Se utilizó una columna Aminex HPX-87H 300mmx7.8mm, la fase móvil fue $5 \mathrm{mM} \mathrm{H}_{2} \mathrm{SO}_{4}, 40^{\circ} \mathrm{C}$ y flujo de $0.6 \mathrm{~mL} / \mathrm{min}$. Para la determinación de astaxantina se utilizó una columna Agilent 


\section{MATERIALES Y MÉTODOS}

Eclipse XD 18 (C18) a una longitud de onda de $470 \mathrm{~nm}$ usando como fase móvil metanol/acetonitrilo/acetato de etilo/agua (80:10:5:5), con un flujo de $1 \mathrm{~mL} / \mathrm{min}$ a $25^{\circ} \mathrm{C}$. La preparación de muestras para determinar glucosa y ácidos orgánicos consistió en diluir el licor en agua desionizada 1:10 y centrifugar a $10,000 \mathrm{rpm}$ durante $20 \mathrm{~min}$ a $4^{\circ} \mathrm{C}$; después se tomó $1 \mathrm{~mL}$ de sobrenadante y se diluyó nuevamente 1:10. Para la determinación de astaxantina las muestras fueron diluidas en acetona 1:10 ( $p / v)$ y centrifugadas a $10,000 \mathrm{rpm}$ durante $20 \mathrm{~min}$ a $4^{\circ} \mathrm{C}$. Finalmente todas las muestras se filtraron utilizando una membrana de $45 \mu \mathrm{m}$ y se inyectaron mediante un automuestreador.

Las identidades de los picos de ácidos orgánicos y astaxantina fueron confirmadas por sus tiempos de retención y los picos correspondientes a los cromatogramas de estándares. (Anexo I).

\subsubsection{Extracción de Astaxantina}

Las muestras sólidas y líquidas se diluyeron en acetona (1:10) con agitación durante $1 \mathrm{~h}$ a temperatura ambiente. Posteriormente fueron filtradas y centrifugadas a 10,000 rpm durante $10 \mathrm{~min}$ a $4^{\circ} \mathrm{C}$ y refrigeradas en oscuridad hasta su análisis.

\subsubsection{Análisis Químico Proximal}

\subsubsection{Determinación del porcentaje de humedad (\%H)}

El porcentaje de humedad se determinó después de secar muestra sólida en crisoles a peso constante durante $24 \mathrm{~h}$ a $110^{\circ} \mathrm{C}$ en una estufa con temperatura controlada, calculando el porcentaje por diferencia de pesos (Ecuación 2) ( $\underline{A O A C, 1990) . ~}$

$$
\% H=\frac{\text { Peso seco crisol con muestra-peso crisol }}{\text { Peso muestra }} \times 100
$$




\section{MATERIALES Y MÉTODOS}

\subsubsection{Determinación del porcentaje de cenizas (\%C)}

El porcentaje de cenizas se determinó por gravimetría. La muestra sólida fue calcinada en crisoles a peso constante, en una mufla a $650^{\circ} \mathrm{C}$, durante $6 \mathrm{~h}$ obteniendo así la diferencia de pesos (Ecuación 3) (AOAC, 1990).

$$
\% \mathrm{C}=\frac{\text { Peso seco crisol con cenizas-peso crisol }}{\text { Peso seco muestra }} \times 100
$$

\subsubsection{Determinación de Nitrógeno total, Nitrógeno proteico, Nitrógeno de quitina y proteína soluble.}

El nitrógeno total y el nitrógeno de quitina se determinó por el método de Kjeldahl, llevando a cabo una combustión en húmedo de la muestra por calentamiento con ácido sulfúrico concentrado en presencia de catalizadores para reducir el nitrógeno orgánico de la muestra hasta amoniaco, el sulfato de amonio producido se alcaliniza y se destila para desprender el amoniaco que posteriormente es atrapado y titulado (Ecuación 4).

$$
\text { Nitrógeno total }=\text { Nitrógeno protéico }+ \text { Nitrógeno no protéico }
$$

El porcentaje de nitrógeno de proteína corregido se calculó mediante la sustracción del nitrógeno de quitina usando como valor de referencia (Yeul y Rayalu, 2013) del nitrógeno total y se multiplicó por el factor 6.25.

La proteína soluble se determinó de acuerdo con el método de Lowry-Peterson (1977) empleado seroalbúmina bovina como estándar. $1 \mathrm{~mL}$ de reactivo Lowry $A$ se añadió a $1 \mathrm{~mL}$ de muestra incubándose por $10 \mathrm{~min}$ a $30^{\circ} \mathrm{C}$. Posteriormente se adicionó $0.5 \mathrm{~mL}$ de reactivo Lowry B e incubándose nuevamente por 30 min. La absorbancia se midió a 750 $\mathrm{nm}$.

\subsubsection{Determinación de los porcentajes de desmineralización y desproteinización.}




\section{MATERIALES Y MÉTODOS}

Los porcentajes de desmineralización (DM) y desproteinización (DP) de cada muestra se calcularon utilizando los porcentajes de cenizas y proteína en los desechos de camarón y los porcentajes residuales después del tratamiento (Ecuación 5) (Pacheco et al., 2011).

$$
Y(\%)=\frac{\left[\left(X_{0} \times S_{0}\right)-\left(X_{R} \times S_{R}\right)\right]}{\left(X_{0} \times S_{0}\right)} \times 100
$$

Dónde:

$$
\begin{aligned}
& Y=\% \text { de desmineralización o desproteinización } \\
& X_{0}=\text { cenizas o proteína de la muestra de camarón } \\
& X_{R}=\text { cenizas o proteína de la muestra fermentada } \\
& S_{0}=\text { peso de la muestra de camarón en base seca } \\
& S_{R}=\text { peso de la muestra fermentada en base seca }
\end{aligned}
$$

\subsubsection{Crecimiento de microorganismos.}

El crecimiento bacteriano en el licor fue determinado por conteo de colonias usando Agar para Métodos Estándar (SMA) para bacterias mesófilas, Agar MRS para bacterias lácticas, Agar Eosina Azul de Metileno (EMB) para coliformes y para crecimiento del hongo se utilizó agar Papa-Dextrosa (PDA) acidificado con 10\% de ácido tartárico a un pH final de 3.5. Los resultados se expresaron como log UFC/mL.

\subsubsection{Determinación de actividad proteolítica.}

La actividad proteolítica a pH 7 se determinó mezclando $75 \mu \mathrm{L}$ de la muestra (licor) diluida previamente $(1: 10 \mathrm{p} / \mathrm{v})$ con $500 \mu \mathrm{L}$ de una solución de caseína al $1 \% \mathrm{p} / \mathrm{v}$ en un amortiguador de fosfatos $50 \mathrm{mM}$ como sustrato. Para la actividad a pH 5, la misma cantidad de muestra se mezcló con una solución 2\% de hemoglobina en buffer universal $0.05 \mathrm{M}$. La mezcla se incubó durante $1 \mathrm{~h}$ a $30^{\circ} \mathrm{C}$ para proteasas neutras y $10 \mathrm{~min}$ para proteasas ácidas, posteriormente se adicionó $1 \mathrm{~mL}$ de ácido tricloroacético al 5\% (p/v) para detener la reacción y se centrifugaron las muestras por $10 \mathrm{~min}$ a 10,000 rpm, por último, se determinó la absorbancia a $280 \mathrm{~nm}$. Una unidad de actividad enzimática se 
MATERIALES Y MÉTODOS

definió como la cantidad de enzima que aumenta 0.001 unidades de absorbancia por minuto al sustrato con respecto a un testigo (Kunitz, 1947; Anson, 1938).

\subsubsection{Determinación de actividad quitinolítica.}

Las muestras de licor fueron diluidas previamente $(1: 10 \mathrm{p} / \mathrm{v})$. Para la determinación de actividad de $\mathrm{N}$-acetilhexosaminidasa ( $\mathrm{NH}$-asa) se utilizó $p$-Nitrofenil- $\beta$-N-acetilglucosamina ( $p N A G)$ (Sigma-Aldrich) como sustrato dónde una unidad de actividad enzimática se definió como la cantidad de enzima que libera $1 \mathrm{~mol}$ de $p$-nitrofenol por minuto. Se añadieron $200 \mu \mathrm{L}$ del extracto enzimático, $200 \mu \mathrm{L}$ de amortiguador de citratos fosfatos 0.2 M pH 5.6, posteriormente se agregó $200 \mu \mathrm{L}$ del sustrato pNAG a una concentración de 1.0 $\mathrm{mg} / \mathrm{mL}$, incubándose a $37^{\circ} \mathrm{C}$ durante una hora con agitación (180 rpm). La reacción se detuvo agregando $1 \mathrm{~mL}$ de $\mathrm{NaOH} 0.02 \mathrm{M}$ a las muestras midiendo en espectrofotómetro (Thermo Fisher Spectronic Genesis 6, EUA) a $400 \mathrm{~nm}$ de absorbancia. Para realizar la estimación del p-nitrofenol liberado empleando una curva patrón mostrada en el Anexo I. Para la actividad de Endoquitinasa se utilizó quitina coloidal y una unidad de actividad enzimática se definió como la cantidad de enzima que reduce la turbidez de la suspensión de quitina coloidal en 0.05 unidades de absorbancia. Se mezclaron $500 \mu \mathrm{L}$ de suspensión de quitina con $500 \mu \mathrm{L}$ del extracto enzimático, incubándose a $30^{\circ} \mathrm{C}$ por $24 \mathrm{~h}$ con agitación de $180 \mathrm{rpm}$. Los testigos se prepararon de igual manera sin incubación. Finalmente, las muestras y testigos se diluyeron en $5 \mathrm{~mL}$ de agua destilada agitando vigorosamente y la absorbancia se leyó a $510 \mathrm{~nm}$.

\subsubsection{SDS-PAGE Tricina}

Para la determinación de la masa molecular de la proteína presente en el licor se realizó un gel de electroforesis en condiciones desnaturalizantes de acuerdo con lo reportado por Schägger (2006). Los 2 geles de separación fueron de 10\% y 16\%. Las condiciones eléctricas fueron $120 \mathrm{~V}$ por $2 \mathrm{~h}$ aproximadamente. La tinción del gel se realizó mediante Coomasie R (Biorad, USA) empleando un marcador de bajo peso molecular (Ultra Low, Biorad) y uno de amplio rango (Biorad, USA). El análisis de bandas se realizó por 
densitometría empleando el programa ImageJ del NIH (Rasband, W.S., ImageJ, U.S. National Institutes of Health, Bethesda, Maryland, USA, http://imagej.nih.gov/ij/,19972014).

\subsubsection{Zimogramas de actividad protelítica y quitinolítica.}

Para los zimogramas de actividad proteolítica se usaron los sustratos caseína para enzimas neutras $(\mathrm{pH} 7)$ y hemoglobina para enzimas ácidas ( $\mathrm{pH}$ 5). Para los zimogramas de actividad quitinolítica se usaron los sustratos 4-metilumbeliferil-N-N-N-acetil- $\beta$-Dquitotriosa para endoquitinasas y 4-metilumbeliferil- $\mathrm{N}$-acetil- $\beta$-D-glucosamina (Sigma Aldrich) NH-asa. Se emplearon geles de poliacrilamida en condiciones semidesnaturalizantes donde la muestra se puso en contacto con $\beta$-mercaptoetanol sin calentamiento. Se agregaron $0.01 \%$ de los sustratos correspondientes en los geles. Al finalizar la electroforesis, el gel se sumergió en $0.1 \mathrm{M}$ de amortiguador de acetato de sodio a pH 5.0 y $1 \%(v / v)$ de Tritón X-100 en agua desionizada y se incubó con agitación suave durante 15 min a temperatura ambiente con la finalidad de remover el SDS. Los geles se transfirieron a amortiguador de acetato de sodio y se incubaron a $37^{\circ} \mathrm{C}$ para dar lugar a la reacción de hidrólisis quitinolítica. La presencia de actividad enzimática se visualizó bajo iluminación ultravioleta como la presencia de zonas acromáticas usando un transiluminador UV de la marca Biorad.

\subsubsection{Actividad antiradicalaria (DPPH e IC50)}

La actividad antioxidante se determinó mediante espectrofotometría usando una solución del radical DPPH al $0.004 \%$ en metanol. Las muestras (licores y astaxantina extraída del licor) se diluyeron hasta obtener una concentración conocida de proteína y se mezclaron con la dilución de DPPH (1:1 v/v). Las muestras se incubaron durante $30 \mathrm{~min}$ a $30^{\circ} \mathrm{C} \mathrm{y}$ posteriormente se leyeron a $517 \mathrm{~nm}$ para calcular la actividad antioxidante (Ecuación 6). El blanco fue una mezcla de agua desionizada con la solución de DPPH.

$$
\% \mathrm{AR}=\left[\frac{A b s B-A b s M}{\mathrm{AbsB}}\right] \times 100
$$


Donde:

\%AR: Actividad antirradicalaria

AbsB: Absorbancia del blanco a $517 \mathrm{~nm}$

AbsM: Absorbancia de la muestra a $517 \mathrm{~nm}$

Para la determinación del $\mathrm{IC}_{50}$ (máxima concentración a la que se obtiene el $50 \%$ de actividad antirradicalaria) se realizaron curvas de cada muestra a diferentes concentraciones determinando la actividad antirradicalaria de cada muestra en cada concentración. Las curvas obtenidas se utilizaron para determinar mediante el análisis probit (NCSS) la dosis correspondiente al IC 50.

\subsubsection{Caracterización de quitina, quitosano y nanofibrillas de quitina.}

\subsubsection{Análisis por espectrofotometrías de infrarrojo (FTIR)}

Los espectros por infrarrojo se obtuvieron de desperdicios de camarón, quitina cruda y quitina purificada (pulverizados, tamizados hasta obtener un tamaño de partícula $<177$ $\mu \mathrm{m}$ y secados $24 \mathrm{~h}$ a $40^{\circ} \mathrm{C}$ ). El análisis se realizó en un sistema ATR equipado con un cristal de zinc y selenio (modelo Spectrum 100 ATR FTIR Perkin Elmer, Estados Unidos) aplicando 64 escaneos por muestra.

\subsubsection{Determinación del grado de acetilación (DA) de quitina.}

La determinación de DA se realizó mediante RMN (Resonancia Magnética Nuclear) de protón $\left(\mathrm{RMN} \mathrm{H}^{1}\right)$. La quitina se disolvió en $\mathrm{DCl}$ concentrado, se agitó por $8 \mathrm{~h}$ a $50^{\circ} \mathrm{C}$ y se diluyó con $\mathrm{D}_{2} \mathrm{O}$. El quitosano se disolvió en $\mathrm{DCl}$ al $1.4 \%$ por $72 \mathrm{~h}$ alternando ciclos de baño maría a $50^{\circ} \mathrm{C}$ por $8 \mathrm{~h}$ cada $24 \mathrm{~h}$. Posteriormente ambas muestras se filtraron con una membrana de $0.45 \mu \mathrm{m}$. Los espectros se obtuvieron en un espectrómetro Bruker CA 300DA.

\subsubsection{Determinación de contenido de solubles y peso molecular por viscosimetría.}

El porcentaje de solubles en la quitina se determinó disolviendo $0.02 \mathrm{~g}$ de la misma en 25 $\mathrm{mL}$ de una solución de $N, N$-dimetilacetamida (DMAC) con cloruro de litio (LiCl) al 5\%, 


\section{MATERIALES Y MÉTODOS}

durante $72 \mathrm{~h}$ con agitación constante a $25^{\circ} \mathrm{C}$; posteriormente se filtró en membrana de fibra de vidrio. Para el quitosano, $0.1 \mathrm{~g}$ se disolvieron en una solución de ácido acético al $2 \%$ con acetato de sodio $0.2 \mathrm{M}$ bajo las mismas condiciones, calentando a baño María (50 C) $8 \mathrm{~h}$ diarias por tres días. Posteriormente la solución se filtró con una membrana de celulosa. Las membranas de fibra de vidrio y celulosa se secaron a $100{ }^{\circ} \mathrm{C}$ durante $24 \mathrm{~h}$. La cantidad de quitina y quitosano disuelto se calculó por diferencia de peso.

Para determinar el peso molecular de ambos biopolímeros se realizó una curva de la solución filtrada para determinar la viscosidad intrínseca. El peso molecular se calculó mediante la ecuación de Mark-Houwink-Sakurada (Ecuación 7) utilizando las constantes correspondientes de la Tabla 3 (Pacheco et al., 2011).

$$
[\eta]=K P M^{a}
$$

Donde:

$\mathrm{PM}=$ Peso molecular

$K$ y $\mathbf{a}=$ parámetros de conformación del polímero dependientes del solvente $\mathrm{y}$ temperatura empleados

Tabla 3. Constantes para determinación de peso molecular viscosimétrico

\begin{tabular}{|l|l|l|}
\hline Constante & Quitina & Quitosano \\
\hline$\kappa$ & $2.4 \times 10^{-4} \mathrm{~L} / \mathrm{g}$ & $1.38 \times 10^{-5}$ \\
\hline $\mathrm{a}$ & 0.69 & 0.85 \\
\hline
\end{tabular}

\subsubsection{Determinación de Índice de cristalinidad $\left(I_{C R}\right)$ y tamaño aparente de cristalito $\left(D_{a p}\right)$.}

El $I_{C R}$ fue determinado por difracción de rayos $x$ (polvos) en un difractómetro (Bruker D8

Advance) con radiación incidente $\mathrm{Cu} K \alpha$ y longitud de onda $\lambda=1.5418 \AA$ en el rango de $2 \theta$ $=4.5$ a $50^{\circ}$ con tamaño de paso de $0.02^{\circ}$. Las intensidades de los picos (110) alrededor de $2 \theta=20^{\circ}$ que corresponde a la zona cristalina, y $2 \theta=16^{\circ}$ que corresponde a la zona amorfa se usaron de acuerdo con la ecuación 8. Los valores del tamaño aparente de cristalito ( $\left.D_{a p}\right)$ fueron determinados de acuerdo con la ecuación Scherrer (Ecuación 9). 


$$
\begin{gathered}
I_{C R}=\frac{I_{110}-I_{a m}}{I_{110}} \times 100 \\
D_{a p[110]}=\frac{K \cdot \lambda}{\beta_{0} \cos \theta}
\end{gathered}
$$

Dónde $\mathrm{K}$ es la constante cerca de $0.9, \lambda$ (angstroms) es la longitud de onda de la radiación incidente, $\beta_{0}(\mathrm{rad})$ es el ancho del pico cristalino a la mitad de altura y $2 \theta(\mathrm{rad})$ es la dispersión del ángulo de la línea de difracción [110] (Pacheco et al., 2011).

La cristalinidad relativa de las nanofibrillas de quitina se calculó mediante la comparación de las áreas de los picos cristalinos contra el área total y se determinó en un difractómetro (Ultima IV, Rigaku) con radiación incidente CuKa operando a 40 kV y $30 \mathrm{~mA}$ en el rango de $2 \theta=5^{\circ}$ a $45^{\circ}$.

\subsubsection{Determinación de viscosidad de suspensiones de nanofibrillas de quitina}

La viscosidad de las suspensiones obtenidas después del pase por molino y micronizador Star Burst se determinó en un viscosímetro digital Brookfield DV-E utilizando un eje LV-4 (Brookfield Engineering Laboratories, Middleboro, MA) a 100 rpm. Las suspensiones sin diluir se colocaron en un tubo con fondo plano y el eje se posicionó justo en el centro evitando la formación de burbujas dejando la muestra en el equipo por 5 min hasta obtener la lectura correcta.

\subsubsection{Determinación de transmitancia}

La transmitancia de suspensiones y películas de nanofibrillas se midió en un espectrofotómetro UV-Vis (V550; JASCO, Tokyo, Japan) realizando un barrido entre 800$200 \mathrm{~nm}$. Las suspensiones fueron diluidas hasta obtener un porcentaje de fibras de $0.1 \%$, se sonicaron $1 \mathrm{~min}$ y se dejaron enfriar, mientras que las películas fueron cortadas a un tamaño de $1 \times 5 \mathrm{~cm}$ para su medición. 


\section{MATERIALES Y MÉTODOS}

\subsubsection{Microscopia Electrónica de Barrido (SEM)}

Las muestras fueron preparadas diluyendo las suspensiones de nanofibrillas en etanol y dejando secar a $100^{\circ} \mathrm{C}$ por $24 \mathrm{~h}$. Posteriormente se recubrieron con una capa de platino y se observaron en un equipo JS-6700F; JEOL, Ltd.

\subsubsection{Determinación de Fuerza de tensión y Módulo de Young}

Las películas de nanofibrillas fueron cortadas a tamaño $1 \times 5 \mathrm{~cm}$ y las pruebas se realizaron en un analizador dual de pruebas mecánicas AG-X, Shimadzu, Tokyo, Japón, utilizando 5 réplicas por muestra. La fuerza de tensión corresponde a la fuerza máxima soportada por la película antes de romperse (Ecuación 10). El módulo de Young corresponde a la pendiente en una curva de fuerza vs tensión (Ecuación 11)

$$
\begin{gathered}
\text { Fuerza }(\mathrm{MPa})=\frac{\mathrm{N}}{(\text { Ancho })(\text { Largo })} \\
\text { Tensión }(\%)=\frac{\text { Largo inicial }}{\text { Largo final }}
\end{gathered}
$$

\subsection{Análisis estadístico}

En cada etapa experimental se realizó un diseño completamente al azar factorial (ANOVA) y la prueba post-hoc Tukey-Kramer con un $\alpha<0.05$. Para el análisis de obtención biológica de quitina las variables de respuesta fueron DM, DP, concentración de ácidos orgánicos, crecimiento de microorganismos, actividad enzimática, concentración de proteína soluble y concentración de astaxantina. Para la comparación de quitina química y biológica, las variables de respuesta fueron peso molecular, porcentaje de solubles, cristalinidad, proteína y minerales residuales. Para el análisis de suspensiones y películas de nanofibrillas de quitina las variables de respuesta fueron viscosidad, transmitancia, cristalinidad, fuerza de tensión y módulo de Young. 


\section{RESULTADOS}

\subsection{Obtención biológica de quitina}

8.1.1. Desmineralización y desproteinización en la obtención de quitina mediante Deterzyme (Quitina DE)

\subsubsection{Desmineralización}

Ya que el uso de la enzima comercial a pH neutro no contribuye a la remoción de minerales, se utilizó $\mathrm{HCl}$ a menor concentración para la DM. El porcentaje de minerales disminuyó de $24 \%$ a $4.89 \%$ obteniéndose un $79.68 \%$ de DM. Por lo anterior, la muestra se diluyó nuevamente en $\mathrm{HCl}$, dando como resultado dos desmineralizaciones, con lo que los minerales se redujeron a $1.12 \%$. Este resultado es contrario al reportado por Mayren en 2013, ya que él reportó un porcentaje de minerales del $1.28 \%$ con una sola desmineralización. La necesidad de realizar dos desmineralizaciones en el presente trabajo puede deberse a la baja concentración del ácido $(0.5 \mathrm{~N})$, que al ser hasta 4 veces menor comparado con otros reportes (Ifuku et al., 2009) puede no ser suficiente para reaccionar con el $\mathrm{CaCO}_{3}$ y demás minerales, por lo que se recomienda aumentar la concentración del ácido para mejorar la desmineralización.

\subsubsection{Proteína soluble y nitrógeno proteico}

La proteína soluble se determinó a partir de los DC y los sobrenadantes obtenidos después del tratamiento con buffers y la enzima Deterzyme ${ }^{\circledR}$ (Figura 4). El desecho de camarón presentó $0.42 \mathrm{~g}$ proteína/g desecho, la cual fue removida principalmente por la acción de los buffers $A$ y $B$. Se ha reportado previamente la remoción de ambos tipos de proteína mediante soluciones iónicas, lo cual corresponde a los resultados obtenidos (Mayren, 2013). Al remover la proteína con dos tipos de buffers se observó que la mayor parte de la proteína total de la muestra $(6.23 \mathrm{~g})$ fue removida por el buffer A, siendo $4.07 \mathrm{~g}$ correspondientes a la proteína sarcoplásmica, mientras que el buffer B removió $1.63 \mathrm{~g}$ del total, correspondiente a proteína miofibrilar. La enzima Deterzyme removió $0.19 \mathrm{~g}$ de la proteína estromal, que es la más difícil de eliminar del exoesqueleto de camarón ya que se 
encuentra embebida en la matriz. En total $5.89 \mathrm{~g}$ de proteína fueron eliminados mediante ambos tratamientos, dando un porcentaje de desproteinización de 94.64\%.

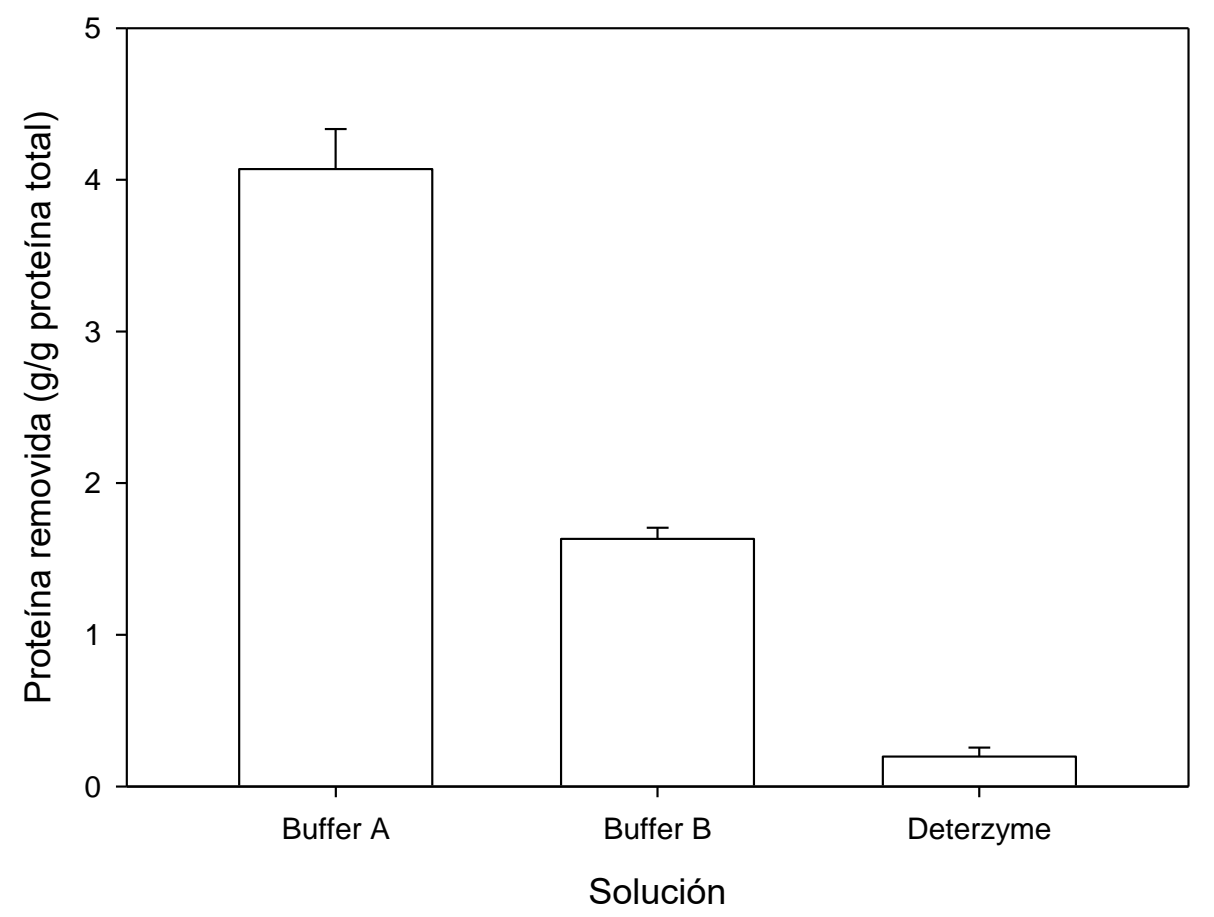

Fig. 4. Proteína soluble removida de desechos de camarón mediante soluciones buffer y la enzima comercial Deterzyme.

El porcentaje de proteína fue también determinado por Kjeldahl mediante el cálculo de nitrógeno total, dando como resultado una DP de $79.44 \pm 6 \%$. Este porcentaje fue menor al previamente reportado por Mayren en 2013, quién obtuvo una DP de 94.64\%. Esto puede deberse a que la enzima no pudo acceder a la proteína que se encuentra interactuando con la cadena de quitina, ya que aún había minerales residuales, los cuáles al depositarse entre fibras para conferir dureza a la cutícula puedieron bloquear la acción enzimática. Por lo anterior se recomienda mejorar la DM previo al empleo de la enzima, con el fin de aumentar la remoción de proteína miofibrilar (Raabe et al., 2006). 


\section{RESULTADOS Y DISCUSIÓN}

\subsubsection{Cultivo en DC mediante inoculación sucesiva de Lactobacillus brevis y distintos}

niveles de Rhizopus oligosporus para la obtención de quitina.

\subsubsection{Comparación de $p H, A T T, D M y$ DP}

El pH inicial de todos los tratamientos fue cercano a 8, finalizando en valores menores a 4.5 a las $192 \mathrm{~h}$ totales del cultivo (Tabla 4). Únicamente los tratamientos L, R10 $10^{3}$ y $10^{5}$ presentaron los valores de pH significativamente más altos, por lo que la inoculación sucesiva de bacteria y hongo es efectiva para disminuir el pH. Éste mismo comportamiento se observa en la ATT, dónde los cultivos con la inoculación de L y R con el nivel más alto de inóculo presentaron mayor acidez, lo que a su vez coincide con el valor de DM significativamente mayor en el cultivo L/R $10^{7}$. En cuanto a DP, se observa que la mayor parte de los tratamientos presentaron porcentajes entre $54 \%$ y $72 \%$, siendo nuevamente el cultivo L/R $10^{7}$ el que presenta el valor significativamente más alto. Por lo anterior se concluye que el cultivo con inoculación sucesiva de $L$ y $R$ con el nivel de esporas de $10^{7}$ es más efectivo para remover los minerales y proteínas de los DC, aun cuando la inoculación de sólo un microorganismo logra disminuir el pH, la concentración o tipo de ácido no es suficiente para desmineralizar arriba del $62 \%$, cómo se observa en los cultivos dónde $\mathrm{R}$ es el único microorganismo inoculado, en los cuales es probable que la microbiota ya presente en los DC (Centeno y Rodríguez, 2007) sean los microorganismos principales debido al lento crecimiento del hongo, por lo que estos microorganismos consumen la fuente de carbono añadida para producir distintos tipos de ácidos orgánicos además del ácido láctico, lo que afecta la remoción de minerales. Este mismo factor puede afectar la DP, ya que la diversidad de microorganismos en el cultivo varía a su vez el tipo y concentración de proteasas producidas, disminuyendo así la remoción de proteína. También puede observarse que la sola inoculación de L remueve tan sólo el $50 \%$ de minerales y el $72 \%$ de proteína, resultado contrario a lo reportado por Cira y colaboradores (2002), quienes obtuvieron una DM y DP de $85 \%$ y $87 \%$, respectivamente. Esto puede deberse a que, en el trabajo mencionado, la concentración de calcio era de $14 \%$ aproximadamente, y dado que éste es el principal mineral encontrado en exoesqueletos de camarón (Younes y Rinaudo, 2015; Talylor et al, 2015), el porcentaje de 


\section{RESULTADOS Y DISCUSIÓN}

minerales fue menor comparado con el que se encontró en los DC utilizados en este trabajo (30\%), lo que se traduce en menor remoción de minerales. La DP de $87 \%$ puede estar igualmente relacionada a la menor concentración de minerales, ya que a menor concentración habrá más sitios disponibles para la acción enzimática.

Tabla 4. Resultados de pH, ATT, DM y DP obtenidos en el tiempo final de los cultivos con inoculación de Lactobacillus brevis (L) y distintos niveles de Rhizopus oligosporus (R).

\begin{tabular}{|c|c|c|c|c|c|}
\hline $\begin{array}{c}\mathrm{L} \\
(\% \mathrm{v} / \mathrm{p})\end{array}$ & $\begin{array}{c}\mathbf{R} \\
\text { (esporas/g } \\
\text { DC) }\end{array}$ & pH & $\begin{array}{c}\text { ATT } \\
\text { (mmol ácido } \\
\text { láctico /g DC) }\end{array}$ & $\begin{array}{l}\text { DM } \\
\text { (\%) }\end{array}$ & $\begin{array}{l}\text { DP } \\
\text { (\%) }\end{array}$ \\
\hline 5 & 0 & $4.48 \pm 0.03^{\mathrm{a}}$ & $0.32 \pm 0.00^{b, c}$ & $52.4 \pm 2.47^{a}$ & $72.6 \pm 3.7^{b}$ \\
\hline 0 & $10^{3}$ & $4.27 \pm 0.05^{a, b}$ & $0.10 \pm 0.03^{a}$ & $53.35 \pm 5.51^{\mathrm{a}}$ & $54.75 \pm 0.67^{a}$ \\
\hline 0 & $10^{5}$ & $4.03 \pm 0.06^{b}$ & $0.32 \pm 0.01^{b, c}$ & $51.09 \pm 2^{\mathrm{a}}$ & $69.38 \pm 2.66^{b}$ \\
\hline 0 & $10^{7}$ & $4.48 \pm 0.2^{\mathrm{a}}$ & $0.29 \pm 0.02^{b}$ & $61.80 \pm 2.4^{\mathrm{a}, \mathrm{b}}$ & $70.96 \pm 0.22^{b}$ \\
\hline 5 & $10^{3}$ & $4.19 \pm 0.01^{b}$ & $0.33 \pm 0.02^{b, c}$ & $52.8 \pm 0.03^{a}$ & $71.8 \pm 3.19^{b}$ \\
\hline 5 & $10^{5}$ & $4.13 \pm 0.01^{b}$ & $0.37 \pm 0.05^{d}$ & $53.5 \pm 1.6^{a}$ & $68.0 \pm 4.1^{b}$ \\
\hline 5 & $10^{7}$ & $4.12 \pm 0.01^{b}$ & $0.34 \pm 0.02^{c, d}$ & $67.3 \pm 1.4^{b}$ & $96.0 \pm 2.12^{c}$ \\
\hline
\end{tabular}

Con los resultados anteriores, se decidió repetir el cultivo L/R $10^{7}$ y realizar toma de muestra cada $24 \mathrm{~h}$ para caracterizar los compuestos obtenidos en el cultivo.

\subsubsection{Caracterización del cultivo L/R $10^{7}$ a través del tiempo}

\subsubsection{1. $\mathrm{pH}$ y ATT}

El cultivo repetido inició con un pH de 7.2, bajando dos unidades en las primeras $24 \mathrm{~h}$, a partir de las cuales el descenso de pH fue paulatino hasta llegar a un final de 4.3 (Figura 5), resultado similar al obtenido en el tratamiento L/R $10^{7}$ realizado inicialmente (Tabla 4). A partir de las $168 \mathrm{~h}$ no hay diferencia significativa en los valores de $\mathrm{pH}$. La acidez tuvo un 


\section{RESULTADOS Y DISCUSIÓN}

aumento de $0.2 \mathrm{mmol} / \mathrm{g}$ las primeras $48 \mathrm{~h}$, a partir de las cuales aumentó lentamente hasta $0.34 \mathrm{mmol} / \mathrm{g}$ a las $192 \mathrm{~h}$, sin embargo; no hay diferencia significativa a partir de las $96 \mathrm{~h}$, por lo que la cantidad de ácidos orgánicos generados se mantiene reaccionando con el carbonato de calcio y demás minerales en los DC, lo que impide que el ATT siga aumentando.

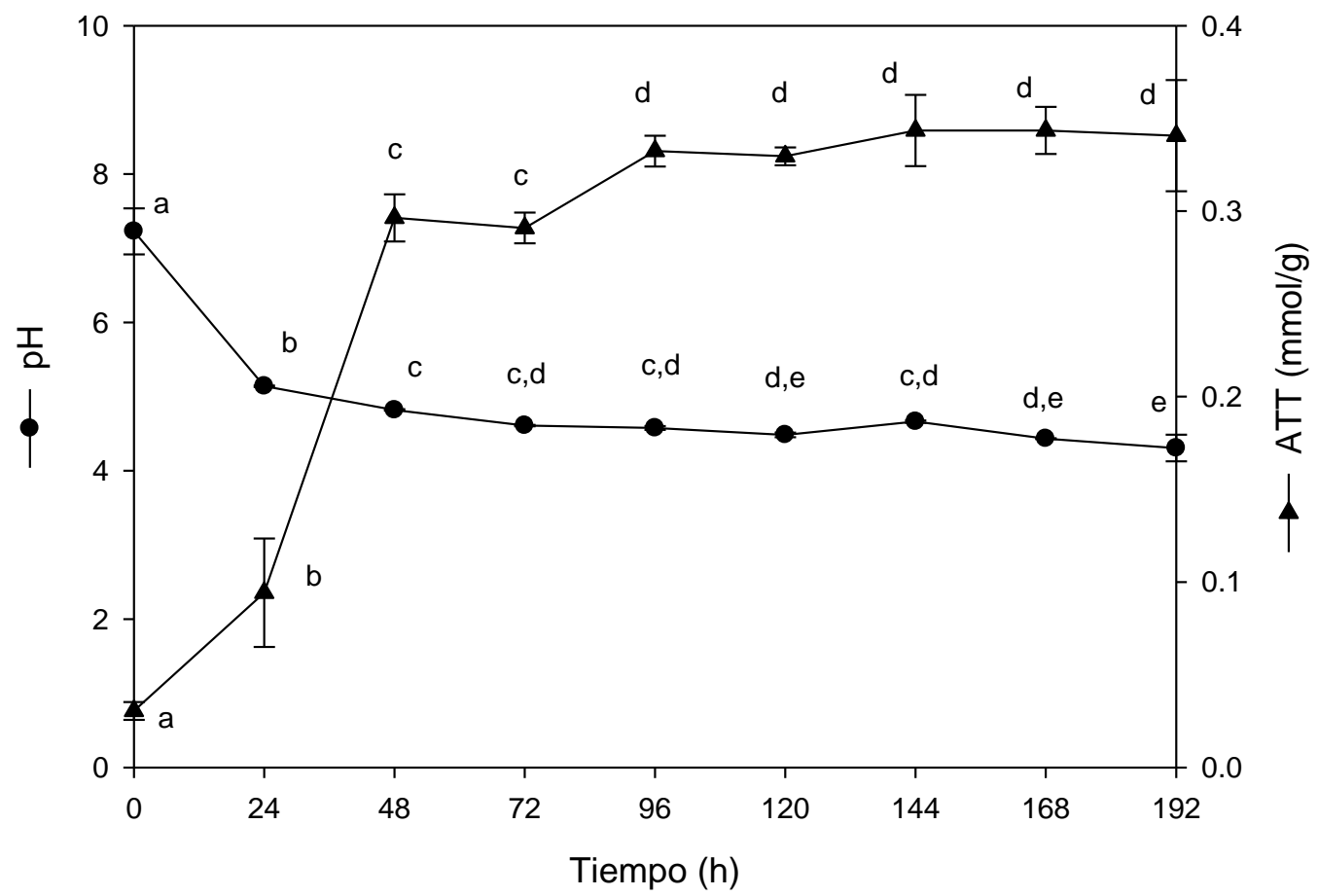

Fig. 5. $\mathrm{pH}$ y ATT del cultivo L/R10 7 realizando determinaciones cada $24 \mathrm{~h}$. Letras distintas indican que las determinaciones de $\mathrm{pH}$ y ATT a través del tiempo son significativamente

diferentes entre ellas (Tukey-kramer $\mathrm{p}<0.05$ ). Los valores más pequeños de $\mathrm{pH}$ se representan con la letra e y las concentraciones más altas de ATT se indican con la letra $d$.

\subsubsection{2. Ácidos orgánicos y glucosa.}

Se realizó el análisis de ácidos orgánicos contenidos en el licor mediante HPLC, obteniéndose que el ácido orgánico principalmente producido fue el ácido láctico, el cual aumenta hasta $0.4 \mathrm{mmol} / \mathrm{g}$ las primeras $72 \mathrm{~h}$, y continúa incrementándose hasta 0.53 $\mathrm{mmol} / \mathrm{g}$ a las $120 \mathrm{~h}$. Posteriormente desciende a $0.35 \mathrm{mmol} / \mathrm{g}$ hasta llegar al tiempo final. Los ácidos succínico, oxálico y acético se encontraron en cantidades menores a 0.1 $\mathrm{mmol} / \mathrm{g}$. El ácido succínico estuvo presente a partir de las $24 \mathrm{~h}$ llegando a $0.094 \mathrm{mmol} / \mathrm{g}$ a 


\section{RESULTADOS Y DISCUSIÓN}

las 129 h, mientras que el ácido acético se encontró a partir de las 48 h, llegando a 0.067 $\mathrm{mmol} / \mathrm{g}$ a las $96 \mathrm{~h}$. La producción de ambos ácidos comenzó a disminuir después de haber obtenido la máxima concentración a las horas mencionadas. La producción de ácido oxálico fue detectada a partir de las $144 \mathrm{~h}$ y hasta las $192 \mathrm{~h}$, coincidiendo con la inoculación de $\mathrm{R}$ y alcanzando $0.018 \mathrm{mmol} / \mathrm{g}$ al final del cultivo. Los ácidos málico y fumárico no fueron detectados en las muestras. La concentración de glucosa desciende 98\% en las primeras 24 h, observándose el aumento en la concentración después de las 120 h, momento de la inoculación de R y adición de glucosa. Posteriormente el consumo de glucosa fue menor comparado con las primeras $24 \mathrm{~h}$ de cultivo, coincidiendo igualmente con la disminución en la producción de ácidos orgánicos.

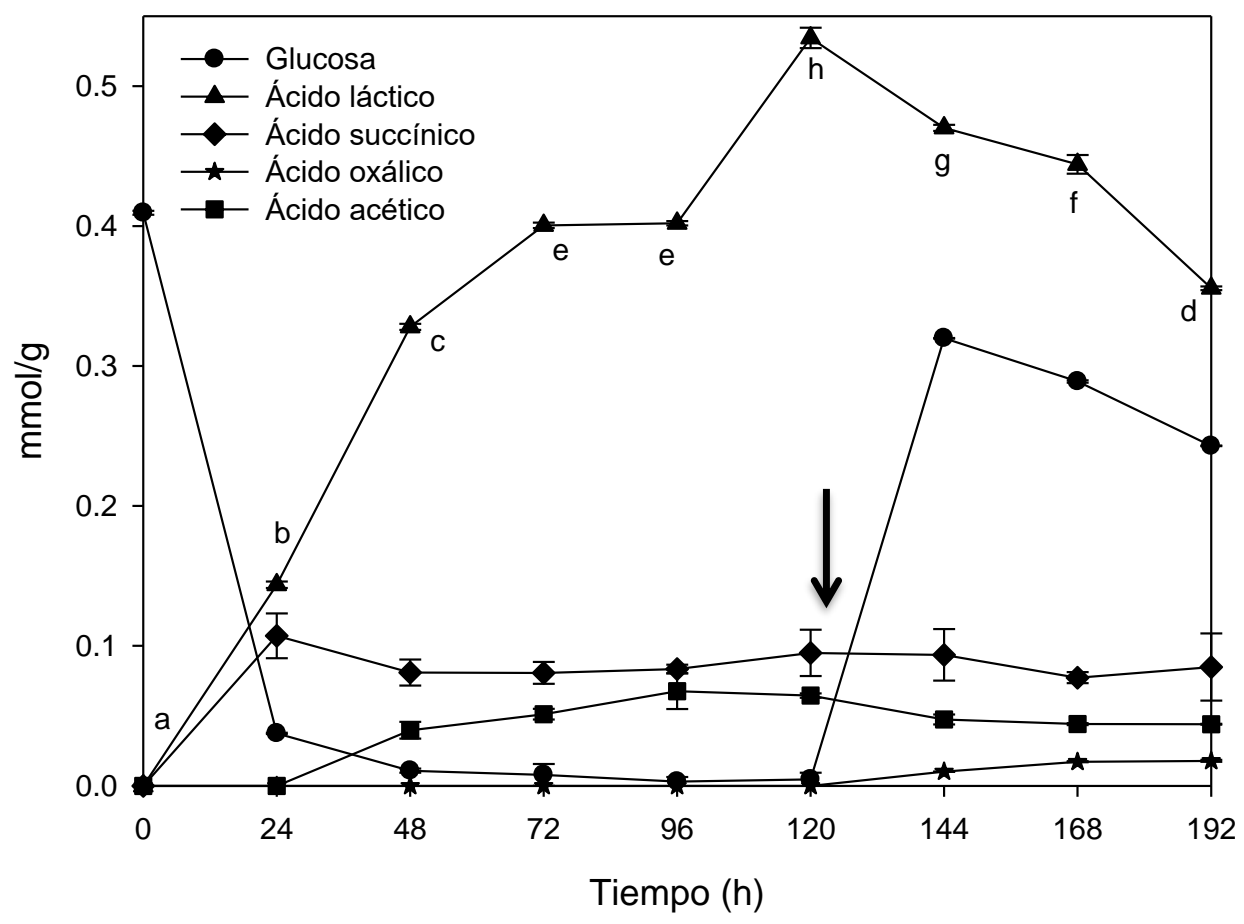

Fig. 6. Producción de ácidos orgánicos y consumo de glucosa del cultivo L/R10 ${ }^{7}$ determinada por HPLC. La flecha indica la adición de $10 \%$ de glucosa y la inoculación de R. En las concentraciones de ácido láctico determinadas cada $24 \mathrm{~h}$, las letras distintas indican que los valores son significativamente diferentes entre ellos (Tukey-Kramer $p<0.05$ ). La letra $h$ señala la concentración más alta. 


\section{RESULTADOS Y DISCUSIÓN}

La producción de otros ácidos orgánicos además del ácido láctico puede deberse a los microorganismos heterofermentativos presentes en el desecho de camarón (enteno et al., 2007), lo cual coincide con lo reportado por Özcelik y colaboradores en 2016, quienes reportan el cultivo de bacterias lácticas en caldo MRS e infusiones de productos pesqueros, encontrando que la producción de distintos tipos de ácidos orgánicos depende de la especie de bacteria, siendo el ácido succínico el que se produjo en mayor concentración $(0.92 \mathrm{~g} / \mathrm{L})$, superando la producción de ácido láctico $(0.23 \mathrm{~g} / \mathrm{L})$, mientras que el ácido acético fue el de menor proporción con solo $0.08 \mathrm{~g} / \mathrm{L}$. Estos resultados concuerdan con los presentados en la Figura 6, ya que después del ácido láctico, el que presentó mayor concentración fue el ácido succínico, mientras que el ácido oxálico fue el de menor concentración y sólo se encontró una vez que el hongo fue inoculado. Por lo anterior, la producción de ácido succínico es principalmente atribuida al metabolismo de L (heterofermentativa) y otras bacterias mesófilas presentes en el DC, pues su concentración se mantiene constante aún después de la inoculación de $R$, mientras que el ácido oxálico producido se atribuye al hongo, puesto que sólo se detectó a partir de las $120 \mathrm{~h}$ coincidiendo con su inoculación. El cromatograma (Anexo II) mostró un pico extra que no pudo ser identificado, el cual aparece después del pico correspondiente a ácido oxálico, por lo que hay otros tipos de ácidos o compuestos generados por los microorganismos presentes en los DC ya inoculados, como puede ser el ácido cetoglutárico (Bell et al., 1991), que se encuentra como intermediario en el ciclo de Krebs.

\subsubsection{3. $D M$ y $D P$}

El porcentaje de desmineralización fue menor al $5 \%$ las primeras 48 h, aumentando a $20 \%$ hasta las $72 \mathrm{~h}$ y aumentando un aproximado de $30 \%$ a $120 \mathrm{~h}$ (Figura 7). Posteriormente el aumento fue lento hasta llegar a un $65 \%$. 


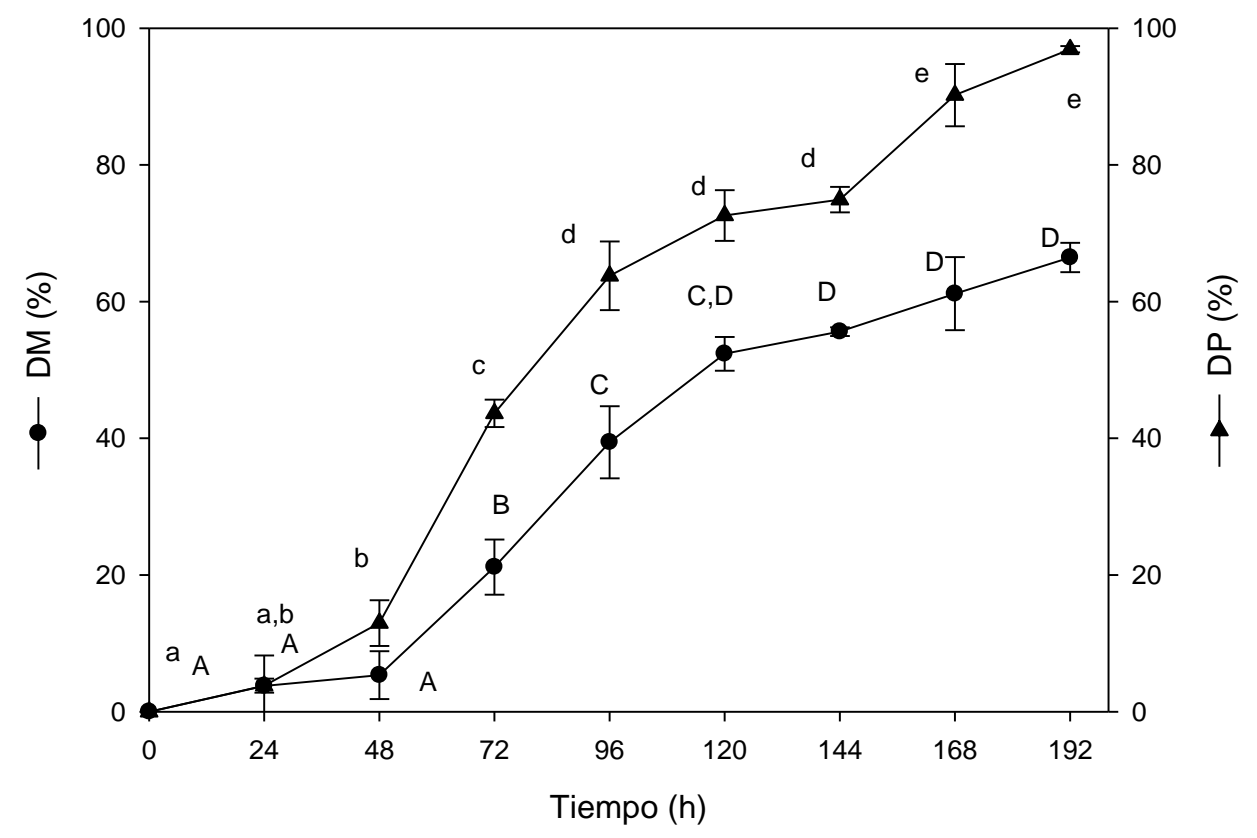

Fig. 7. DM y DP del cultivo L/R10 7 realizando determinaciones cada $24 \mathrm{~h}$. Letras distintas (mayúsculas=DM, minúsculas=DP) en cada determinación indican porcentajes significativamente diferentes entre ellos (Tukey-Kramer $p<0.05$ ). Para DM, los porcentajes mayores se indican con la letra $D$; para DP se señalan con la letra $e$.

De acuerdo con el análisis estadístico, a partir de las $144 \mathrm{~h}$ no hubo diferencia significativa con el porcentaje a las $192 \mathrm{~h}$, sin embargo, hay que notar que la muestra de $168 \mathrm{~h}$ presentó una desviación mayor a las muestras de $192 \mathrm{~h}$, por lo que es recomendable continuar el cultivo hasta tiempo final.

El porcentaje de desproteinización fue de $96.90 \%$, resultado que concuerda con el cultivo inicial, el cual presentó igualmente la DP más alta. Las muestras a las 168 h y 192 h no mostraron diferencia significativa, sin embargo, la desviación de la muestra a las $168 \mathrm{~h}$ presentó una desviación alta, al igual que en DM, por lo que es recomendable continuar el cultivo hasta las $192 \mathrm{~h}$ para obtener el máximo porcentaje (Figura 7).

El valor de DM (66.45\%) fue menor comparado con otros reportes (Cira et al., 2002; Jung et al., 2006; Mao et al., 2013; Liu et al., 2014), en los cuáles el DM alcanza 83\%, 97.2\%, 


\section{RESULTADOS Y DISCUSIÓN}

$92 \%$ y $95 \%$. Sin embargo, en los trabajos mencionados, el cultivo se realizó como cultivo sumergido utilizando solamente $30 \%$ de DC además de ajustarse a pH de 6.5 , lo que aumentó la DM de $83 \%$ a 97\%; o bien se realizó un pretratamiento para los DC; mientras que en el presente trabajo se utilizó el $87 \%$ en cultivo sólido sin ajuste de pH inicial o pretratamiento. Otro aspecto es que, a pesar de obtener baja DM, la quitina obtenida puede ser utilizada directamente como quitina calcárea, la cual no requeriría ningún proceso de purificación y tiene varias aplicaciones como son la preservación de vegetales y tratamiento de agua (Agulló et al., 2003). Dependiendo de la posible aplicación de la quitina, ésta puede ser posteriormente desmineralizada con baja concentración de ácido. La DP fue más alta (96\%) que la previamente reportada (hasta $87 \%$ ), por lo que no se requiere remover proteína residual, lo que disminuye el uso de álcalis.

\subsubsection{Crecimiento de microorganismos.}

El crecimiento de bacterias mesófilas, como pueden ser Bacillus y Pseudomonas, entre otras (Centeno y Rodríguez, 2007), se observa en las primeras 24 h, manteniéndose constante hasta las $120 \mathrm{~h}$, después de las cuáles comienza a disminuir, comportamiento que se observa también en las bacterias lácticas. La disminución en el crecimiento de bacterias mesófilas y lácticas en el cultivo se relaciona con la inoculación del hongo, el cual crece hasta las $144 \mathrm{~h}$ y comienza a disminuir hasta las $192 \mathrm{~h}$ (Figura 8). Los coliformes aumentan hasta las $48 \mathrm{~h}$, tiempo en el cual comienzan a disminuir hasta ser completamente inhibidos a las $96 \mathrm{~h}$, lo que puede relacionarse con la producción de ácido láctico y acético, los cuales tienen su concentración más alta en ese tiempo y es también el tiempo en el que la ATT llega a su concentración máxima. 


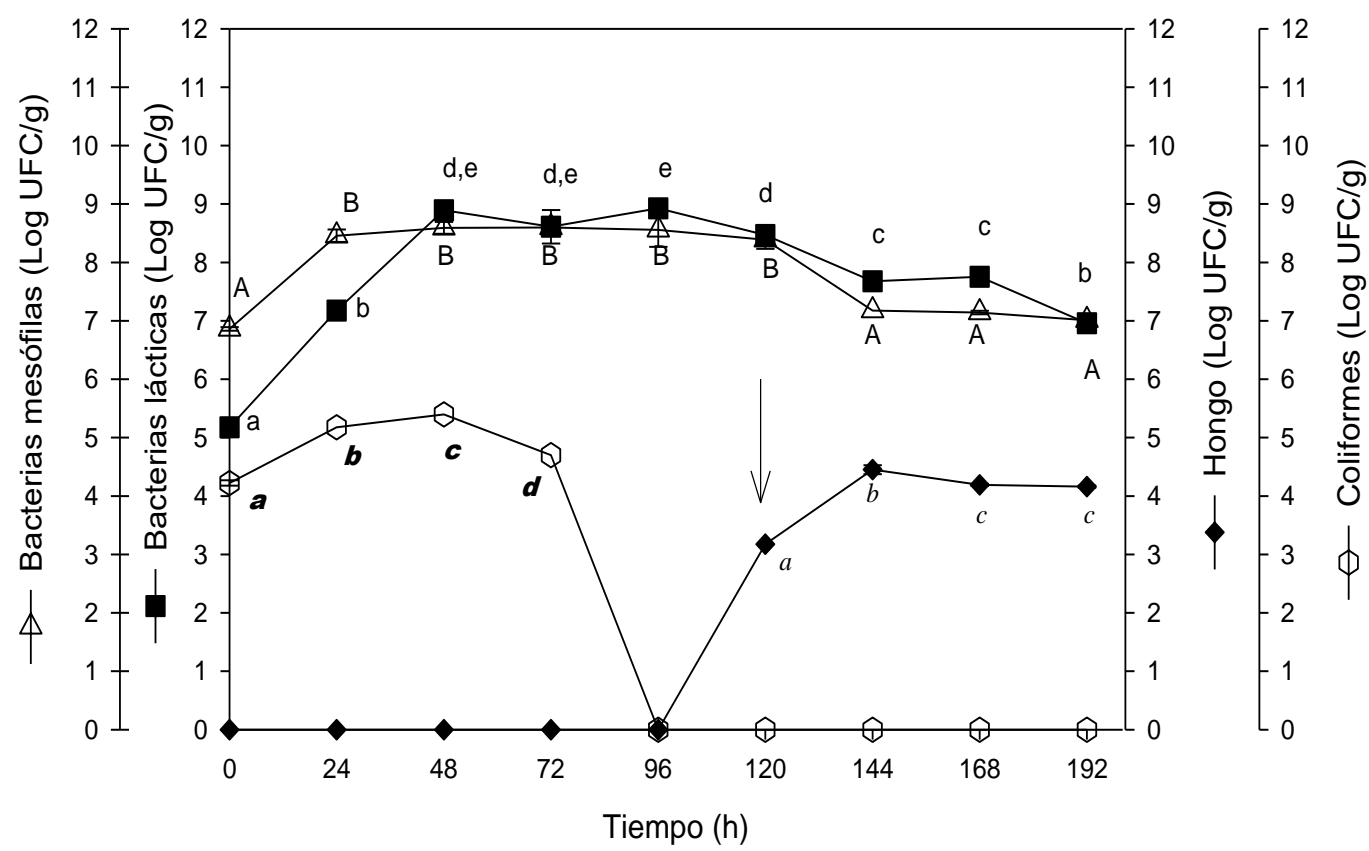

Fig. 8. Crecimiento de microorganismos en muestras tomadas cada $24 \mathrm{~h}$ del licor del cultivo L/R107. Letras distintas en determinaciones a lo largo del tiempo para cada microorganismo (mayúsculas=bacterias mesófilas, minúsculas= bacterias lácticas, resaltadas $=$ bacterias coliformes, cursivas=hongos) indican valores significativamente diferentes entre si (Tukey-Kramer $p<0.05$ ). El valor mayor para bacterias mesófilas se indica con la letra $B$, para bacterias lácticas con la letra " $\mathrm{e}$ ", para bacterias coliformes con la letra $c$ y para hongos con la letra $b$.

El crecimiento del hongo es lento y se detiene después de las $144 \mathrm{~h}$, lo que puede deberse a bajo oxígeno disponible, ya que el hongo cuenta con metabolismo aerobio, así como a interacciones sinérgicas entre los ácidos carboxílicos y compuestos fenólicos producidos por L, como lo reportan Peyer y colaboradores en 2016, quienes observan la inhibición del hongo Fusarium culmorum por las sustancias producidas por $\mathrm{L}$ usando sustrato de cebada. Sin embargo, también se ha reportado que el crecimiento de $R$ en tempe no es inhibido por especies del género Lactobacillus (Feng et al., 2005), lo que indica que el sustrato en donde crecen las bacterias lácticas puede ser un factor para la producción de ácidos orgánicos y su interacción con otros componentes. 


\section{RESULTADOS Y DISCUSIÓN}

La disminución en el conteo de bacterias lácticas al inocular el hongo puede deberse a alguna sustancia inhibitoria generada por R (Roubos-van den Hill et al., 2009), efecto que ha sido investigado contra la bacteria Bacillus cereus en la elaboración de tempe.

\subsubsection{Actividad proteolítica}

Las proteasas presentes en el licor mostraron actividad en ambos valores de $\mathrm{pH}$, a excepción de las proteasas neutras a las 24 h y 48 h (Figura 9). Esto muestra que las proteasas neutras cuentan con un alto rango de actividad, ya que el $\mathrm{pH}$ varía desde aproximadamente 8 hasta 4.6. Puede observarse también un aumento en la actividad de proteasas neutras a partir de las $48 \mathrm{~h}$, lo cual puede deberse a la producción de nuevas enzimas con actividad presente en un amplio rango de $\mathrm{pH}$ por parte de $\mathrm{L}$, como se muestra en el SDS-PAGE de tricina en la sección 8.1.3.7; donde se observa la aparición de nuevas bandas de $30 \mathrm{KDa}$ aproximadamente, coincidiendo con el PM reportado para proteasas (Amund et al., 1990)

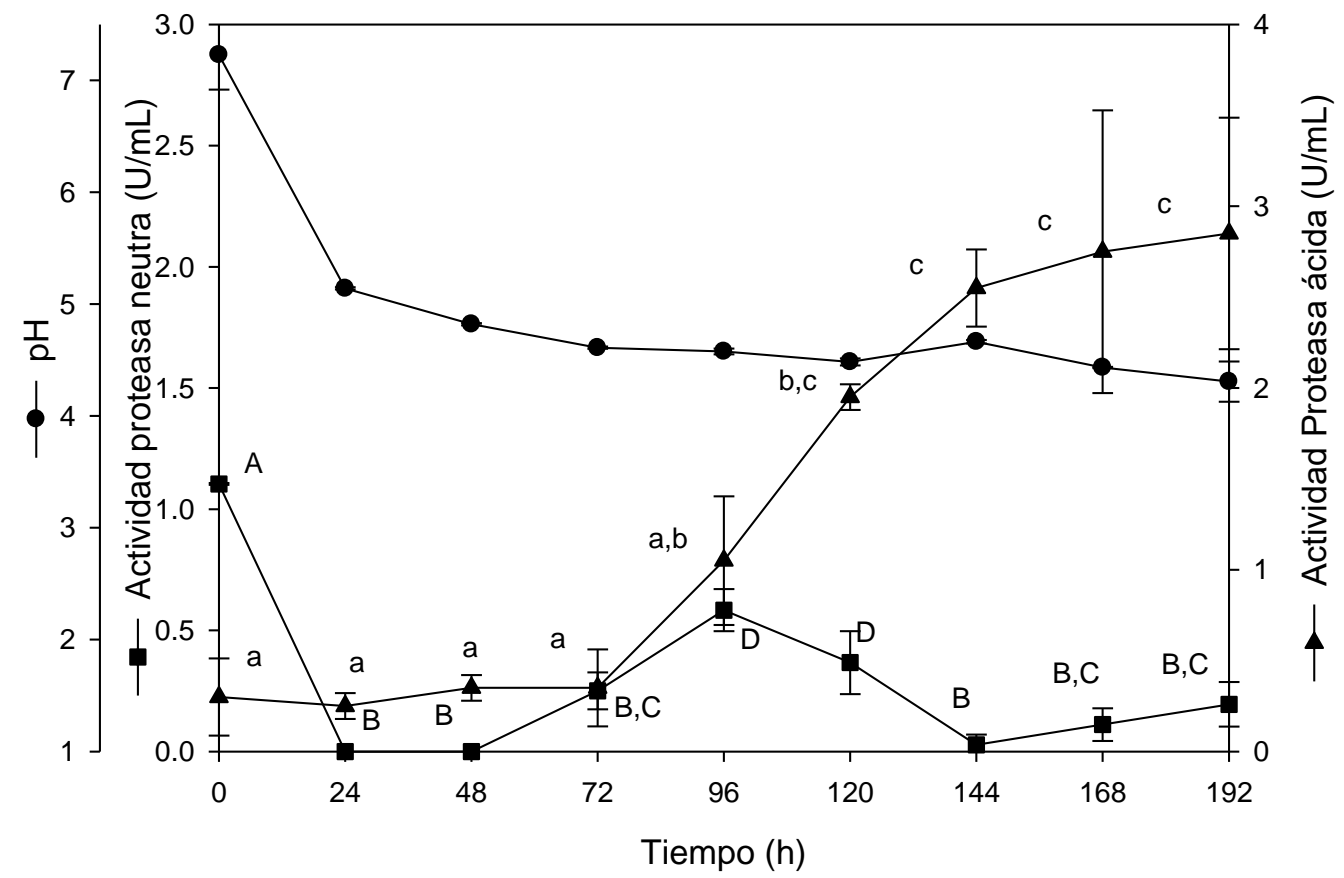

Fig. 9. Actividad proteolítica de enzimas a pH 7 y 5 presentes en licor del cultivo L/R10 ${ }^{7}$ y su comparación con las determinaciones de $\mathrm{pH}$. Letras distintas en las determinaciones realizadas a través del tiempo (minúsculas=proteasas ácidas, mayúsculas=proteasas 


\section{RESULTADOS Y DISCUSIÓN}

neutras) indican grupos significativamente diferentes entre ellos (Tukey-Kramer $\mathrm{p}<0.05$ ). La actividad más alta para proteasas a $\mathrm{pH} 7$ se indica con la letra $A$ y para proteasas a $\mathrm{pH} 5$ se indica con la letra $c$.

La actividad proteolítica a pH 5 es tres veces menor que la actividad neutra a las $0 \mathrm{~h}$, ya que el $\mathrm{pH}$ es de 7.6. Posteriormente, la actividad se iguala y aumenta hasta $2.85 \mathrm{U} / \mathrm{mL}$, coincidiendo con la baja de $\mathrm{pH}$ en el licor. Las proteasas ácidas mostraron de igual manera actividad en un amplio rango de $\mathrm{pH}$, estando presentes desde el inicio del cultivo. La alta actividad a pH ácido coincide con los reportes previos sobre $\mathrm{R}$, cuya actividad es más alta a pH menor o igual a 5 (Ikasari y Mitchell, 1996; Li y Li, 2013). A pesar de que la actividad de proteasas neutras aumenta a las $72 \mathrm{~h}$ y $96 \mathrm{~h}$, la actividad es menor $(0.64 \mathrm{U} / \mathrm{mL})$ que la obtenida por proteasas ácidas $(1 \mathrm{U} / \mathrm{mL})$.

Horas de cultivo

$\begin{array}{llllllll}24 & 48 & 72 & 96 & 120 & 144 & 168 & 192\end{array}$
Horas de cultivo

$\begin{array}{llllllll}24 & 48 & 72 & 96 & 120 & 144 & 168 & 192\end{array}$

Fig. 10. Zimogramas de actividad protelítica a pH a) Ácido y b) Neutro de muestras tomadas cada $24 \mathrm{~h}$ del licor del cultivo L/R10 ${ }^{7}$

La alta actividad proteolítica a pH 5 se observa también en los zimogramas de actividad. La actividad de proteasas ácidas (Figura 10a) es más evidente que la actividad de proteasas neutras (Figura 10b), ambas aumentando con el tiempo de cultivo. La actividad también se vuelve más clara después de las 120 h, coincidiendo con la inoculación del hongo. Esto confirma que las proteasas de $\mathrm{R}$ son más estables a pH ácido, habiéndose reportado que 


\section{RESULTADOS Y DISCUSIÓN}

un $\mathrm{pH}$ de 5 es el óptimo para la actividad de proteasas del hongo en sustratos como semillas de girasol y salvado de trigo y arroz (Haq y Mukthar, 2004).

\subsubsection{Actividad quitinolítica}

Los reportes previos sobre algunas enzimas quitinolíticas de R mencionan que su actividad está limitada a la biosíntesis de la pared celular, ya que la presencia de quitina en el medio no contribuyó a la expresión de sus genes codificantes. Sin embargo, estos estudios se enfocan en la codificación y expresión de los genes de quitinasas específicas, por lo que la influencia de quitina en el medio de crecimiento del hongo sobre la producción de quitinasas directo en el medio de cultivo no ha sido estudiado previamente (Takaya et al., 1998). Al realizar la determinación de actividad quitinolítica, se encontró presencia de actividad de $\mathrm{N}$-acetil hexosaminidasa ( $\mathrm{NH}$-asa). La $\mathrm{NH}$-asa es una exoquitinasa que actúa en el extremo no reductor de la cadena liberando $\mathrm{N}$-acetilglucosamina. Esta quitinasa presentó actividad a lo largo del cultivo (Figura 11), incluyendo los tiempos iniciales hasta las 96 h aún cuando el hongo no había sido inoculado, lo que se debe a la actividad de quitinasas presentes en la cutícula de camarón, las cuales son necesarias en el proceso de muda. También puede observarse que la actividad aumenta después de las $120 \mathrm{~h}$, una vez que $\mathrm{R}$ fue inoculado, y disminuye a partir de las $144 \mathrm{~h}$. 


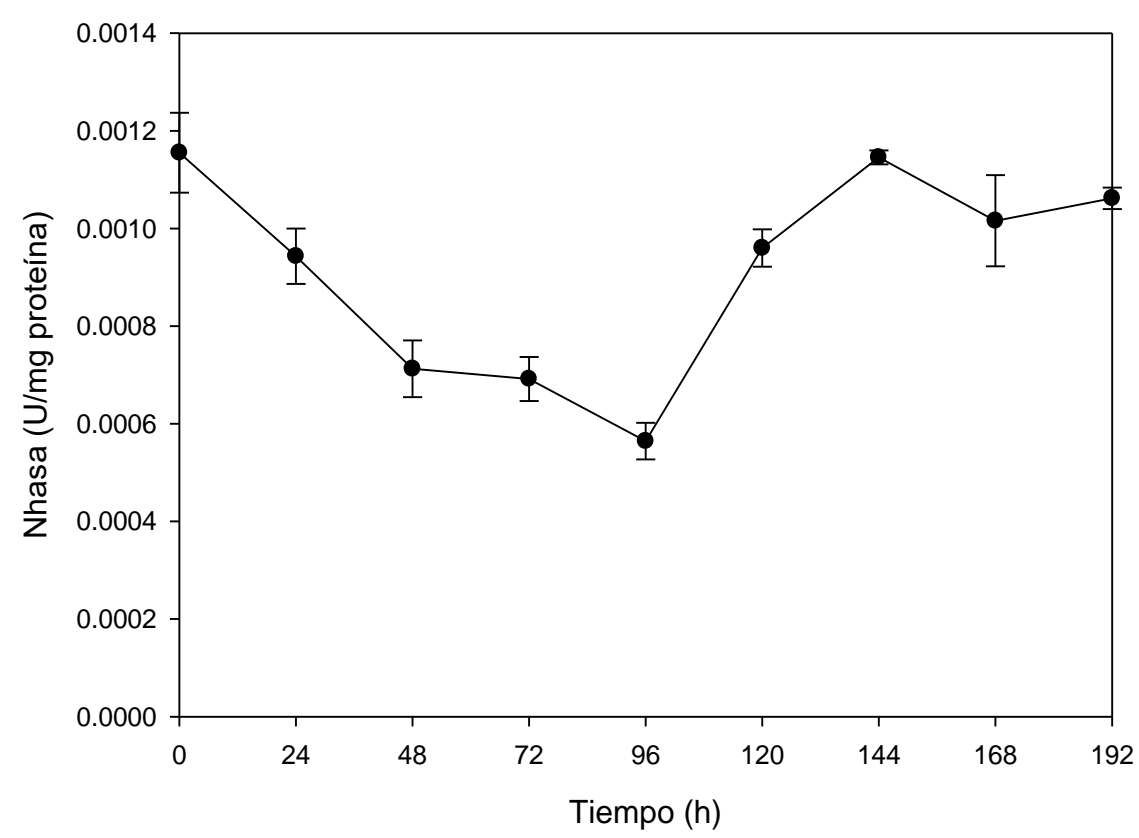

Fig. 11. Actividad de $\mathrm{N}$-acetil hexosaminidasa en muestras tomadas cada $24 \mathrm{~h}$ del licor del cultivo L/R107.

La disminución en la actividad de la Nhasa puede deberse al lento crecimiento de $\mathrm{R}$ a partir de ese tiempo, lo que índica menor producción de quitinasas, así como a la disminución de sustrato para la acción de la enzima, ya que su acción es precedida por la actividad de endoquitinasas, que rompen la cadena en puntos internos al azar, lo que provee de sustrato (oligómeros) a las exoquitinasas. Dado que la actividad de endoquitinasas en el licor de cultivo fue levemente detectada en zimogramas, más no en la determinación espectrofotométrica, se infiere que la actividad es mínima, lo que no es suficiente para generar los oligómeros necesarios para la acción de la NH-asa. Esto se debe a que el licor se colocó sin dilución para preparar el zimograma, mientras que para la determinación de actividad el licor se diluyó previamente, lo que disminuyó considerablemente la concentración de endoquitinasa, disminuyendo así la detección de actividad. 


\section{RESULTADOS Y DISCUSIÓN}

La actividad de endoquitinasa (Figura 12a) y NH-asa (Figura 12b) fue también determinada mediante zimogramas, observándose que estuvo presente a lo largo del cultivo, siendo mayor la actividad de Nhasas, lo que confirma los resultados presentados anteriormente.

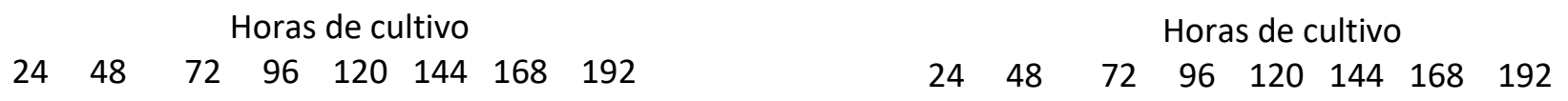
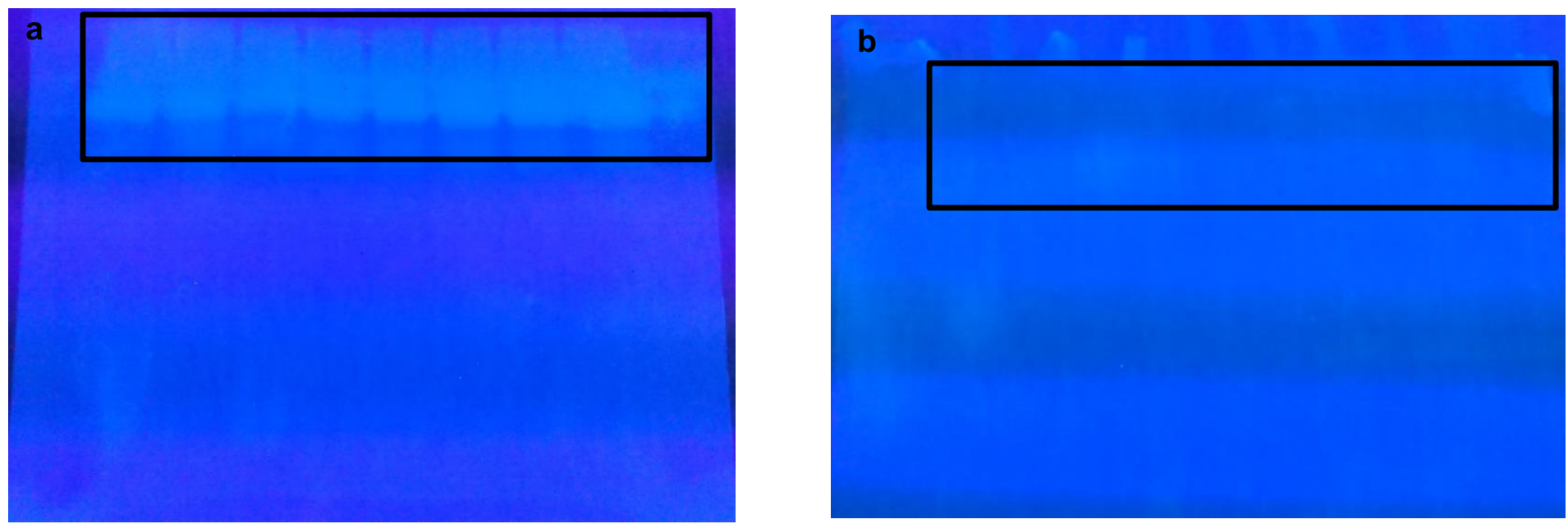

Fig. 12. Zimogramas de actividad quitinolítica de muestras tomadas cada $24 \mathrm{~h}$ del licor del cultivo L/R 107. a) Endoquitinasas, b) Nhasas

\subsubsection{Concentración de proteína, astaxantina y actividad antioxidante presente en el licor}

La concentración de proteína aumentó paulatinamente hasta las 96 h, tiempo en el que fue significativamente más alta $(120.57$ mg/g de DC). Posteriormente la concentración disminuye y se mantiene constante hasta las 192 h. La concentración de proteína más alta para la actividad antioxidante $\left(\mathrm{IC}_{50}\right)$ se observó a las $0 \mathrm{~h}$, mientras que la más baja fue a las $24 \mathrm{~h}(1.13 \mathrm{mg} / \mathrm{g}$ de DC). Esto indica que la actividad antirradicalaria más alta se encuentra en el licor a las $24 \mathrm{~h}$ de cultivo, seguida del licor a las $168 \mathrm{~h}$ presentando un $\mathrm{IC}_{50}$ de 1.15 $\mathrm{mg} / \mathrm{g}$ de DC (Figura 13), ya que se busca que una menor concentración de proteína obtenga el mayor porcentaje de actividad antirradicalaria. 


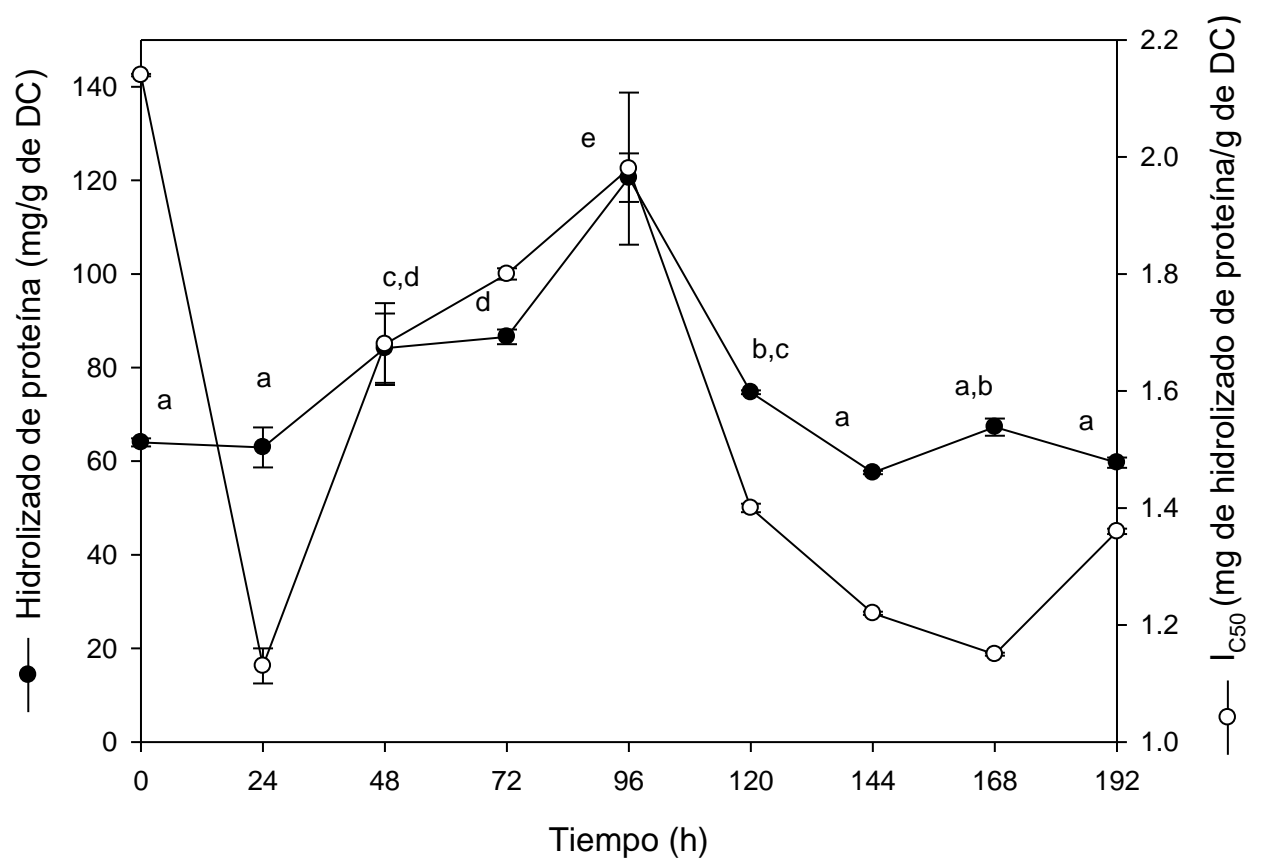

Fig. 13. Concentración de proteína soluble e $\mathrm{IC}_{50}$ presente en muestras de licor tomadas cada $24 \mathrm{~h}$ del cultivo L/R 107 . Letras distintas entre determinaciones de concentración de proteína indican grupos significativamente diferentes entre ellos (Tukey-Kramer $p<0.05$ ). La concentración más alta se indica con la letra $e$.

Marcadores y horas de cultivo

$\begin{array}{llllllllll}\text { M1 } & \text { M2 } & 24 & 48 & 72 & 96 & 120 & 144 & 168 & 192\end{array}$
Marcadores y horas de cultivo

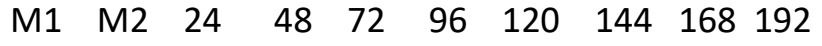
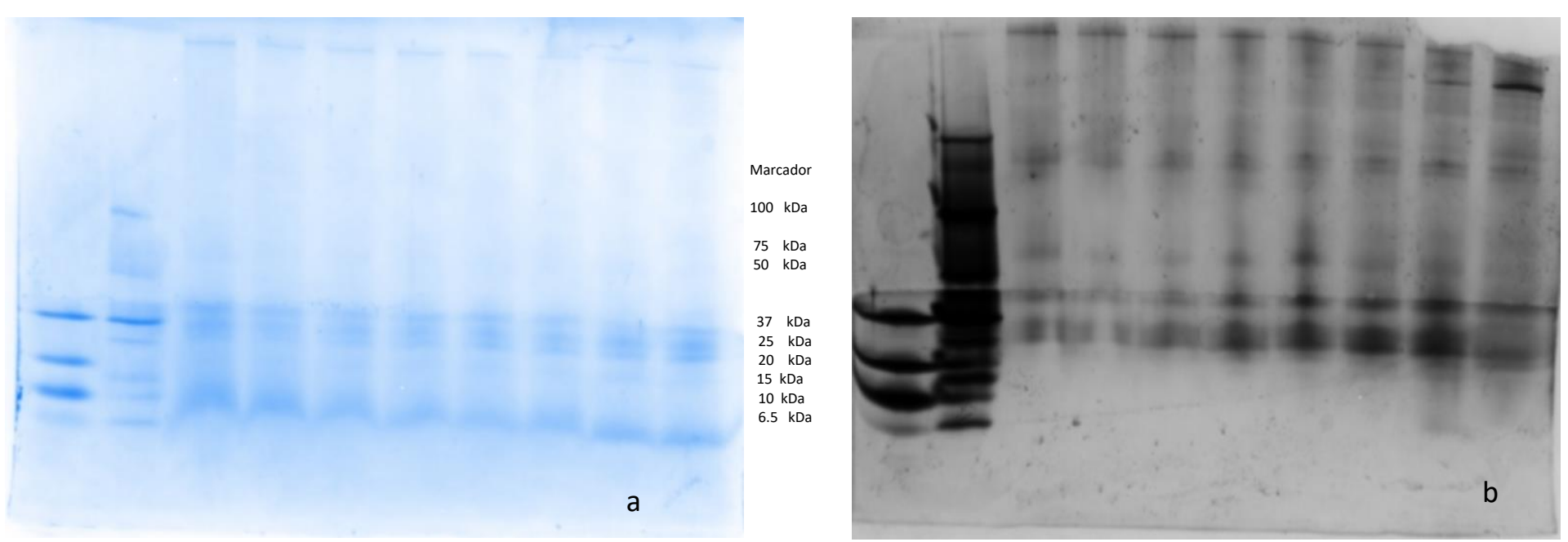

Fig. 14. SDS-PAGE Tricina de muestras tomadas cada $24 \mathrm{~h}$ del licor del cultivo L/R10 ${ }^{7}$. a) Azul de comassie y b) Plata. M1= Marcador de bajo peso molecular y M2= Marcador de amplio rango de peso molecular. 
EI SDS-PAGE de tricina con tinción azul de comassie (Figura 14a) y plata (Figura 14b) mostraron proteínas en el licor con peso superior a los $50 \mathrm{kDa}$ y menores a $6.5 \mathrm{kDa}$ al ir aumentando el tiempo de fermentación. Con la tinción azul de comassie se observa la proteína de bajo peso molecular (hasta $4.5 \mathrm{kDa}$ ) mientras que con la tinción de plata se observan las de alto peso molecular. Esto indica que el proceso de fermentación remueve proteína de la quitina y la inoculación de $\mathrm{R}$ genera proteína de bajo peso molecular, lo que

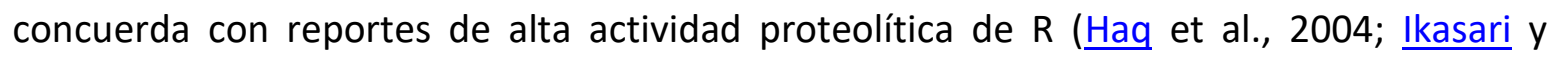
Mitchell, 1996).

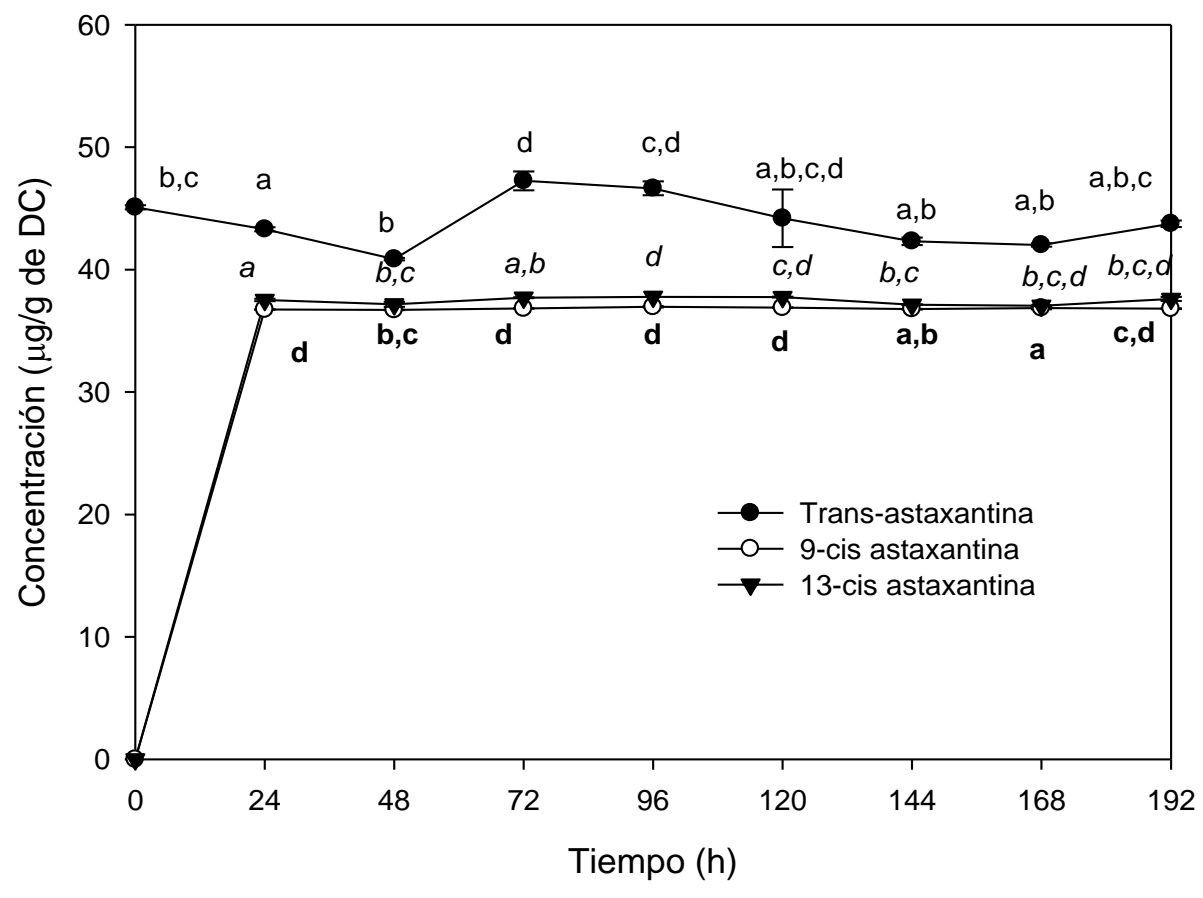

Fig. 15. Concentración de astaxantina extraída de la fracción sólida de muestras tomadas cada $24 \mathrm{~h}$ del cultivo L/R $10^{7}$. Letras distintas entre determinaciones a través del tiempo (normales=trans-astaxantina, cursivas=9-cis astaxantina, resaltadas $=13$-cis astaxantina) indican grupos significativamente diferentes entre concentraciones del pigmento en el sólido (Tukey-Kramer $\mathrm{p}<0.05$ ). Las concentraciones más altas se indican con la letra d para todas las configuraciones de astaxantina. 


\section{RESULTADOS Y DISCUSIÓN}

La concentración de astaxantina en el sólido (quitina) se muestra en la Figura 15. Se observa la presencia de tres isoformas de astaxantina, Trans-, 9-cis y 13-cis. Las isoformas cis- aparecen a partir de las $24 \mathrm{~h}$ de cultivo, esto se debe a que la trans-astaxantina puede cambiar a cis-astaxantina ya sea por temperatura, exposición a la luz o baja de $\mathrm{pH}$, lo que concuerda con la acidez presente a partir de las $24 \mathrm{~h}$. La concentración del pigmento del sólido fue menor comparada con otros reportes (Gimeno et al., 2007; Pacheco et al., 2009), lo que puede deberse al proceso de secado o exposición a la luz, lo que ocasiona pérdida de estabilidad al pigmento, así como al tipo de cultivo empleado o inclusive al lote de DC utilizado.

La concentración de astaxantina del licor disminuyó paulatinamente a lo largo de la fermentación, presentando el valor significativamente más alto a las $48 \mathrm{~h}(8.78 \mu \mathrm{g} / \mathrm{g}$ de DC). Este decremento, al igual que en la astaxantina del sólido, puede deberse a la oxidación del pigmento a lo largo del cultivo. La concentración del pigmento extraído del licor fue igualmente menor comparado con otros reportes donde el pigmento es extraído de la fracción sólida (Figura 15). Sin embargo, la mayor proporción de astaxantina extraída del licor se encontró en forma libre o como trans-isómero, en lugar de estar presente como trans- y cis- isómeros, los cuáles se determinaron en la fracción sólida del cultivo. Lo anterior fue determinado en el cromatograma correspondiente (Anexo II), ya que la presencia de tres picos indica la existencia de trans-, 9-cis y 13-cis astaxantina, respectivamente.

La actividad antioxidante fue determinada en la astaxantina extraída del licor. El IC50 más bajo se observó a las $192 \mathrm{~h}(2.02 \mu \mathrm{g} / \mathrm{g}$ de DC) y el más alto a las $0 \mathrm{~h}(14.87 \mu \mathrm{g} / \mathrm{g}$ de DC) (Figura 16), siendo más alta la actividad antirradicalaria con menor concetración de astaxantina a las $192 \mathrm{~h}$. La alta actividad antirradicalaria de la astaxantina se debe a su presencia en forma libre o como trans-isómero, formas en las que es menos estable en comparación con el cis-isómero, por lo que reacciona más fácilmente con los radicales libres (Pacheco et al., 2009). La alta actividad antirradicalaria de la astaxantina ha sido estudiada previamente, por lo que la astaxantina obtenida del licor puede ser utilizada como un fuerte antioxidante, que además puede ser utilizado en el tratamiento de 
RESULTADOS Y DISCUSIÓN

enfermedades o su prevención, como son cáncer, diabetes y condiciones cardiacas (Ranga et al., 2014). Esto indica que la astaxantina obtenida del tratamiento de DC puede ser industrialmente aprovechable en la rama médica.

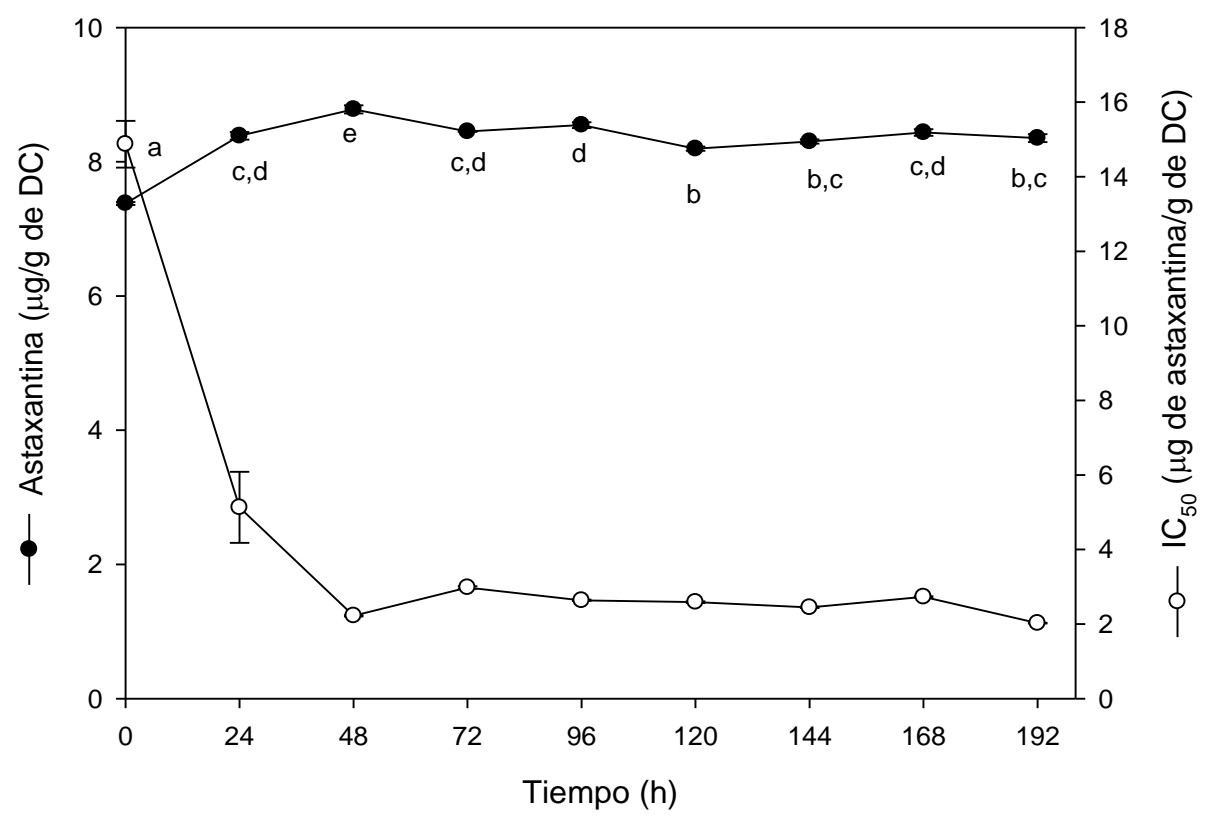

Fig. 16. IC 50 y concentración de astaxantina extraída de licor de muestras tomadas cada 24 $\mathrm{h}$ del cultivo $\mathrm{L} / \mathrm{R} 10^{7}$. Letras distintas entre determinaciones de la concentración de astaxantina indican grupos significativamente diferentes entre ellos (Tukey-Kramer $\mathrm{p}<0.05)$. La concentración más alta se indica con la letra $e$.

Al comparar la actividad antioxidante obtenida en el licor con otros reportes donde se usó a Streptococcus thermophilus y Bacillus spp (Ghorbell-bellaj et al., 2012; Mao et al., 2013) en DC, se observa una menor actividad antirradicalaria; sin embargo, en esos reportes la concentración de desperdicio de camarón usada fue menor a la de este trabajo, por lo que la actividad es mas atribuible a las bacterias presentes en la fracción líquida que a la proteína del camarón y otros compuestos, como es el caso del presente trabajo.

\subsubsection{Caracterización y comparación de quitina DE y la obtenida mediante cultivo con} microorganismos (Quitina LR). 


\section{RESULTADOS Y DISCUSIÓN}

\subsubsection{Caracterización por espectrofotometría infrarroja (ATR-FTIR)}

Las quitinas obtenidas mediante el uso de la enzima comercial Deterzyme y a través del cultivo L/R10 ${ }^{7}$ fueron caracterizadas por espectroscopia infrarroja (Figura 17), observándose la resolución de las principales bandas características en la quitina: vibraciones de estiramiento del hidroxilo $(\mathrm{vOH})$, relacionado con los puentes de hidrógeno intramoleculares a $3460 \mathrm{~cm}^{-1}$ y $3450 \mathrm{~cm}^{-1}$, estiramiento asimétrico y simétrico del grupo amino $(v \mathrm{NH})$ a $3260 \mathrm{~cm}^{-1}$ y $3100 \mathrm{~cm}^{-1}$, respectivamente. Las vibraciones de estiramiento asimétrico del grupo metilo $\left(\mathrm{CH}_{3}\right)$ a $2960 \mathrm{~cm}^{-1}$, el estiramiento simétrico del metileno $\left(\mathrm{CH}_{2}\right)$ a $2930 \mathrm{~cm}^{-1}$, y la vibración de estiramiento del C-H a $2890 \mathrm{~cm}^{-1}$ y $2870 \mathrm{~cm}^{-1}$ (vCH). El estiramiento del grupo carbonilo C=O (enlace sencillo de la amida I) en $1660 \mathrm{~cm}^{-1}$ y 1620 $\mathrm{cm}^{-1}$ (vCO), el doblamiento del grupo amino $(\mathrm{N}-\mathrm{H})$ correspondiente a la amida II a 1560 $\mathrm{cm}^{-1}(\delta \mathrm{NH})$, el doblamiento asimétrico y simétrico del $\mathrm{C}-\mathrm{H}$ a $1415 \mathrm{~cm}^{-1}$ y $1375 \mathrm{~cm}^{-1}(\delta \mathrm{CH})$, respectivamente. El doblamiento del grupo amino a $1310 \mathrm{~cm}^{-1}$ y $1260 \mathrm{~cm}^{-1}(\delta \mathrm{NH})$, el estiramiento simétrico del C-O a $1205 \mathrm{~cm}^{-1}$ (vCO), el estiramiento asimétrico del C-O-C a $1150 \mathrm{~cm}^{-1}$ (enlace glicosídico) y $1110 \mathrm{~cm}^{-1}$ (anillo de glucosa), el estiramiento del hidroxilo correspondiente al C2 en $1050 \mathrm{~cm}^{-1}$ y el correspondiente al C6 en $1010 \mathrm{~cm}^{-1}$. A $950 \mathrm{~cm}^{-1} \mathrm{y}$ $920 \mathrm{~cm}^{-1}$ también se detectan vibraciones de aleteo y balanceo del grupo metilo, respectivamente. El doblamiento del anillo de glucosa se observa a $895 \mathrm{~cm}^{-1}$, así como el balanceo del metileno a $740 \mathrm{~cm}^{-1}$ y el doblamiento fuera de plano de la amida a $688 \mathrm{~cm}^{-1}$ (Teng et al., 2001; Lu et al., 2013; Salaberria et al., 2015).

En el espectro correspondiente a la muestra de quitina $D E$, se observa una banda pronunciada en la región de $2900 \mathrm{~cm}^{-1}$, lo que puede deberse a la interferencia de proteína residual. A pesar de que se observan las bandas características de la quitina, el espectro correspondiente a la quitina LR presenta mejor purificación que la obtenida mediante la enzima Deterzyme. 
RESULTADOS Y DISCUSIÓN

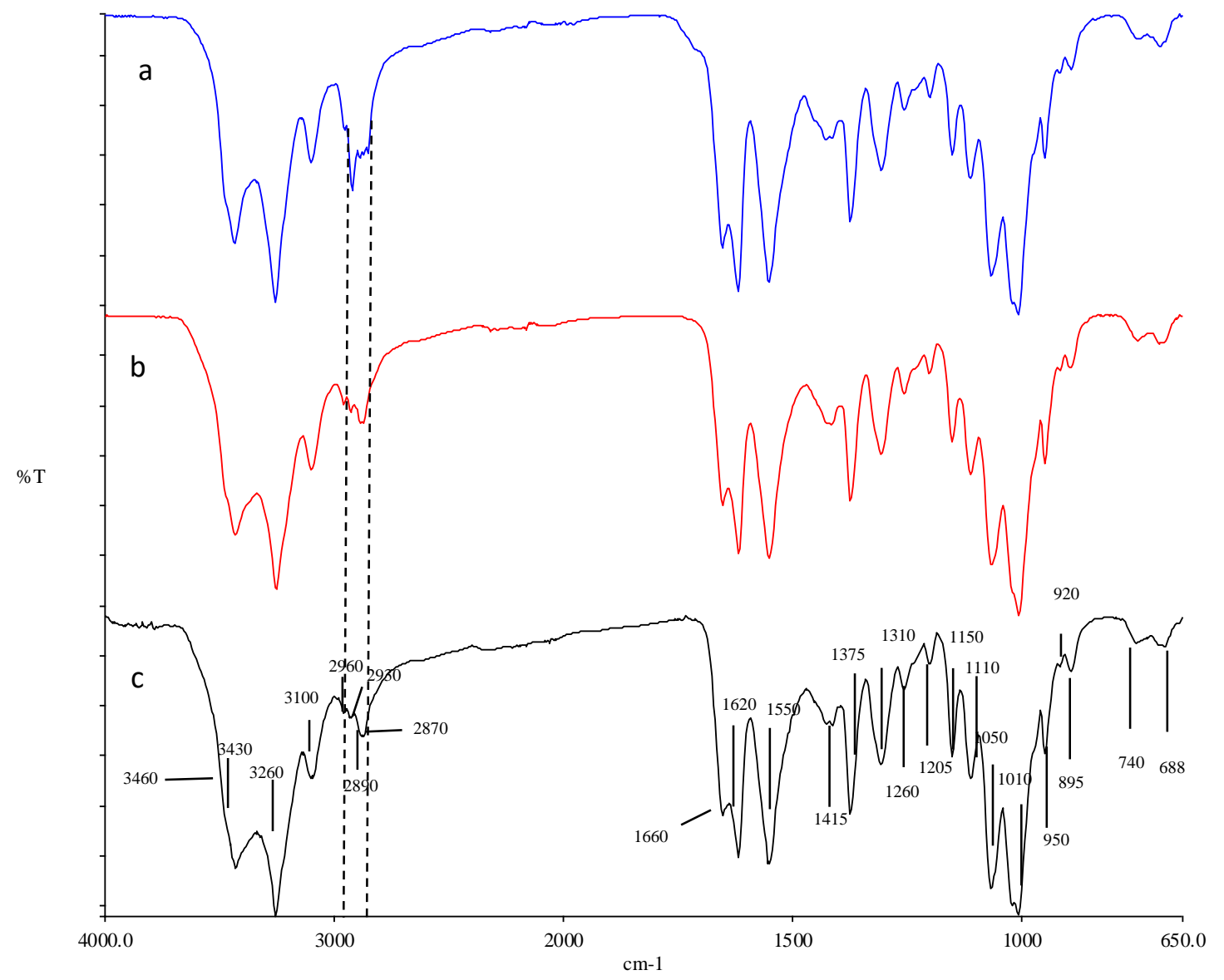

Fig. 17. Espectros infrarrojos obtenidos mediante ATR-FTIR de muestras de quitina extraída mediante a) Desproteinización enzimática, b) Inoculación de microorganismos y su comparación con (c) quitina comercial. Se resalta la región a $2900 \mathrm{~cm}^{-1}$.

\subsubsection{Determinación de grado de acetilación mediante RMN $H^{1}$, peso molecular por viscosimetría y cristalinidad por rayos $x$}

El DA es $4 \%$ mayor en la quitina LR que en la obtenida utilizando la enzima Deterzyme, sin embargo, ambos valores están arriba del 90\% (Tabla 5), lo que coincide con el DA reportado para quitinas. Los espectros de $\mathrm{RMN} \mathrm{H}^{1}$ (Anexo) muestran el $\mathrm{H}_{3}$ del grupo $\mathrm{CH}_{3}$ a 2 ppm, el H correspondiente a los C 2-6 se encuentra de 3 a 4 ppm y el H de C1 y C2 está de 4.6 a 5.4 ppm. Otro aspecto que considerar es el alto DA obtenido en la quitina LR, indicando que no hay actividad de enzimas desacetilasas por parte del hongo ( $\underline{\text { Pacheco }}$ et al., 2011). 
RESULTADOS Y DISCUSIÓN

Tabla 5. Grado de acetilación y peso molecular correspondiente a las quitinas obtenidas por métodos biológicos

\begin{tabular}{ccccc}
\hline $\begin{array}{c}\text { Tratamiento para obtención de quitina } \\
\text { DA (\%) }\end{array}$ & PM (KDa) & $\begin{array}{c}\text { Solubles } \\
\text { (\%) }\end{array}$ & $\begin{array}{c}\text { Viscosidad } \\
\text { intrínseca } \\
\text { (mL/g) }\end{array}$ \\
\hline $\begin{array}{c}\text { Desproteinización enzimática } \\
\text { (DE) }\end{array}$ & 90.22 & $1,338 \pm 22$ & 6.7 & $4,000 \pm 40$ \\
\hline $\begin{array}{c}\text { Cultivo con Lactobacillus brevis y Rhizopus } \\
\text { oligosporus }\end{array}$ & 94.65 & $4,273 \pm 87$ & 14.41 & $9,025 \pm 120$ \\
(LR) & & & & \\
& & & & \\
\hline
\end{tabular}

En cuanto al peso molecular, se observa que la quitina obtenida LR es mayor por 2,935 $\mathrm{KDa}$, lo cual puede deberse a las dos desmineralizaciones realizadas a la quitina $\mathrm{DE}$; sin embargo, también debe tomarse en cuenta el porcentaje de polímero solubilizado, pues ésta última quitina presentó la mitad de solubles que la quitina LR. Esto indica que el PM de la quitina DE puede ser mayor al valor presentado en la tabla 5. La viscosidad intrínseca [n] en ambas muestras de quitina presentó valores mayores a los reportados para tratamientos biológico-químicos y químicos (Kurita, 2001; Pacheco et al., 2011) donde la viscosidad intrínseca es de $3000 \mathrm{~mL} / \mathrm{g}$ aproximadamente. El alto peso molecular en la quitina LR es consistente con estudios previos, lo que indica que la actividad de quitinasas no afecta el peso molecular de la quitina.

De acuerdo con los resultados obtenidos, la quitina LR presenta mayor DP, DA y PM, por lo que el análisis de rayos $X$ para determinar el ICR se realizó únicamente sobre esa muestra, presentando un IcR de $95.71 \%$ y un $D_{a p}$ de $59.55 \%$. La cristalinidad es más alta que aquella reportada para quitina extraída por método biológico-químico (Pacheco et al., 2011) que fue de 86.4\%. El patrón de difracción (Anexo IV) mostró principalmente 5 picos, de los cuales el pico más intenso corresponde a 110. Ya que la cristalinidad de la quitina es reportada como alta, el cultivo con microorganismos y el uso de $\mathrm{HCl}$ de baja concentración no afectaron la cristalinidad. 


\section{RESULTADOS Y DISCUSIÓN}

\subsubsection{Conclusiones parciales sobre la extracción biológica de quitina}

Utilizando ambos métodos de purificación biológica, se obtiene quitina purificada con PM mayor al reportado para métodos de extracción química, sin embargo, el PM obtenido al purificar mediante inoculación de microorganismos fue mayor que utilizando Deterzyme, además de que la DP fue menor mediante la desproteinización enzimática. A esto se le añade la necesidad de dos procesos de desmineralización, lo que genera un uso mayor de químicos que en su mayoría pueden ser sustituidos por los ácidos orgánicos generados durante el cultivo. Otro aspecto es que la proteína removida mediante soluciones buffer, previo al uso de Deterzyme, difícilmente puede ser recuperada si se compara con los hidrolizados proteicos obtenidos al filtrar el cultivo con microorganismos, aunado a la recuperación de astaxantina, la cual no podría ser recuperada en su totalidad ni con la misma actividad antioxidante de la quitina desproteinizada enzimáticamente. Una de las ventajas de la utilización de buffers y enzimas comerciales es el tiempo en el que se obtiene la quitina, el cual es más corto ya que el tiempo de reacción para las soluciones buffer es de 30 minutos en conjunto, además de las $5 \mathrm{~h}$ requeridas para la desmineralización química y la acción de la enzima comercial. Este tiempo puede aumentar con base en el lapso de secado del sustrato; sin embargo, es considerablemente menor comparado con los 8 días requeridos para el cultivo. Aún con esta ventaja, también debe considerarse que la concentración de agua requerida para la preparación de soluciones y enjuagues entre cada paso es mayor que en el cultivo, ya que éste último no necesita más agua de la que contiene, aunado a que las características de la quitina LR son mejores para los objetivos de este trabajo.

Por lo anterior, la quitina obtenida mediante inoculación sucesiva Lactobacillus brevis y Rhizopus oligosporus sobre DC fue la mejor opción para continuar con el escalamiento de la extracción biológica de quitina, con lo cual se busca extraer un lote de quitina con el cual poder obtener nanofibrillas y quitosano de alto PM. 


\section{RESULTADOS Y DISCUSIÓN}

\subsection{Aplicación del cultivo L/R $10^{7}$ para generar mayor lote de quitina.}

\subsubsection{Caracterización a través del tiempo}

\subsubsection{1. pH y ATT}

Para asegurar que el comportamiento del cultivo con $100 \mathrm{~g}$ de DC (Koji) se repitiera al aplicarse sobre una mayor cantidad de desperidicio, se realizó la determinación de pH y ATT (Figura 18), observando que la disminución de pH se da lentamente no habiendo diferencia significativa después de las $72 \mathrm{~h}$, contrario al cultivo con menor cantidad de DC, en la que el $\mathrm{pH}$ disminuye drásticamente las primeras $24 \mathrm{~h}$. El valor final del cultivo grande fue de 4.6, mientras que para el cultivo tipo Koji fue de 4.3.

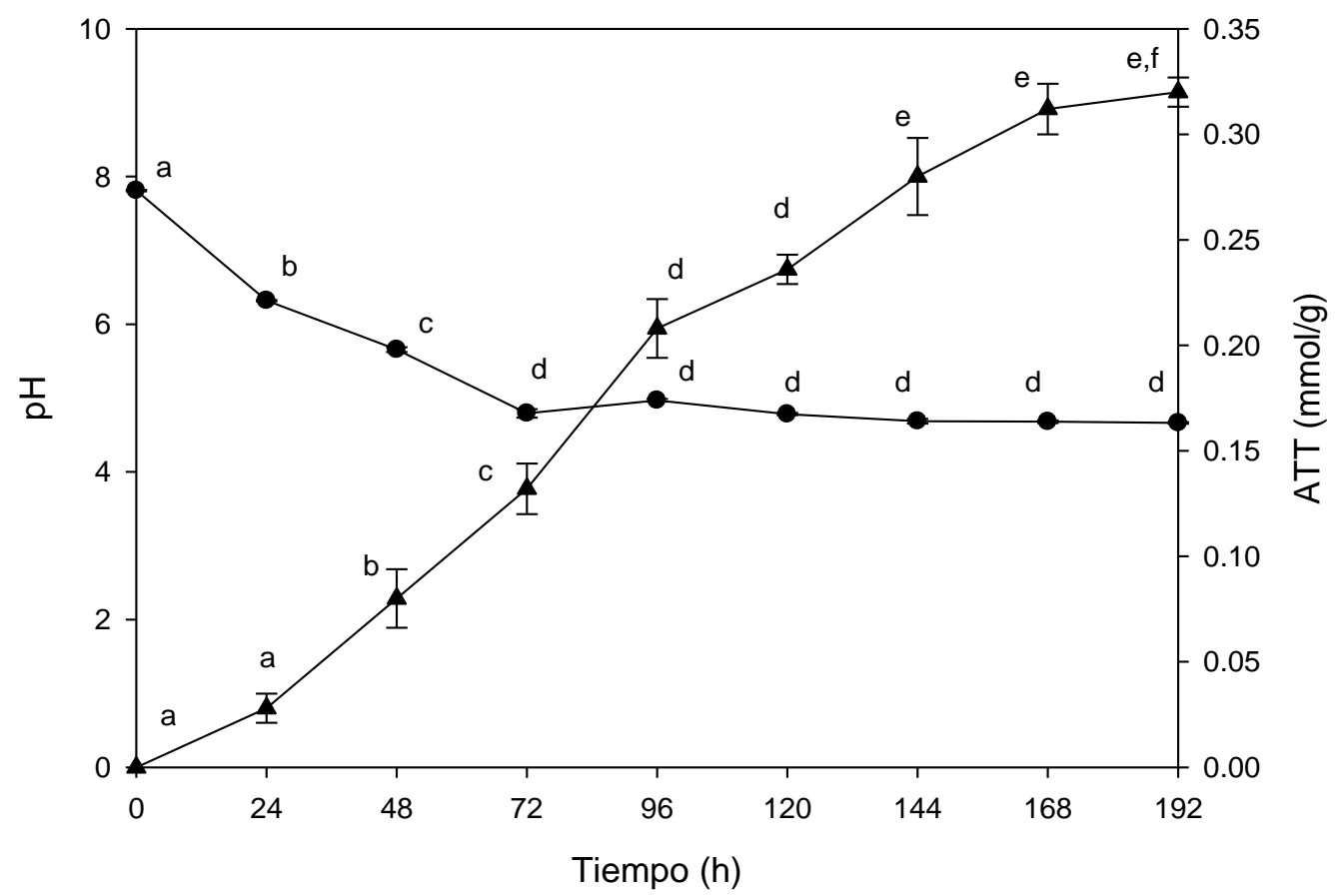

Fig. 18. pH y ATT de la repetición del cultivo L/R10 $10^{7}$ sobre $8 \mathrm{Kg}$ de DC realizando determinaciones cada $24 \mathrm{~h}$. Letras distintas en las determinaciones indican que son grupos significativamente diferentes entre ellos (Tukey-Kramer $\mathrm{p}<0.05$ ). Las muestras con $\mathrm{pH}$ más bajo se indican con la letra $d$, y las concentraciones más altas de ATT se indican con la letra $f$.

En cuanto a la ATT, el cultivo tipo Koji no presento diferencias a partir de las $96 \mathrm{~h}$ llegando hasta $0.34 \mathrm{mmol} / \mathrm{g}$, mientras que en el cultivo mayor la acidez continúa aumentando, no 


\section{RESULTADOS Y DISCUSIÓN}

presentando diferencias a partir de las $144 \mathrm{~h}$ y alcanzando un máximo de $0.32 \mathrm{mmol} / \mathrm{g}$, por lo que se espera que la DM sea más lenta.

\subsubsection{2. $D M$ y $D P$}

La remoción final de minerales fue menor en el cultivo sobre $8 \mathrm{Kg}$ de DC, llegando solamente hasta el $48 \%$ (Figura 19). La lenta DM (que se mantiene en 0\% las primeras 72 h) se relaciona con la producción gradual de ácido, por lo que el carbonato de calcio del exoesqueleto de camarón actúo inicialmente como un amortiguador, impidiendo que aumentara la remoción de este por reacción con los ácidos orgánicos. Otro aspecto por considerar es que el porcentaje de minerales iniciales en los DC utilizados en el cultivo de $100 \mathrm{~g}$ fue menor (25\%) que en los DC utilizados en la inoculación sobre $8 \mathrm{Kg}$ (31\%).

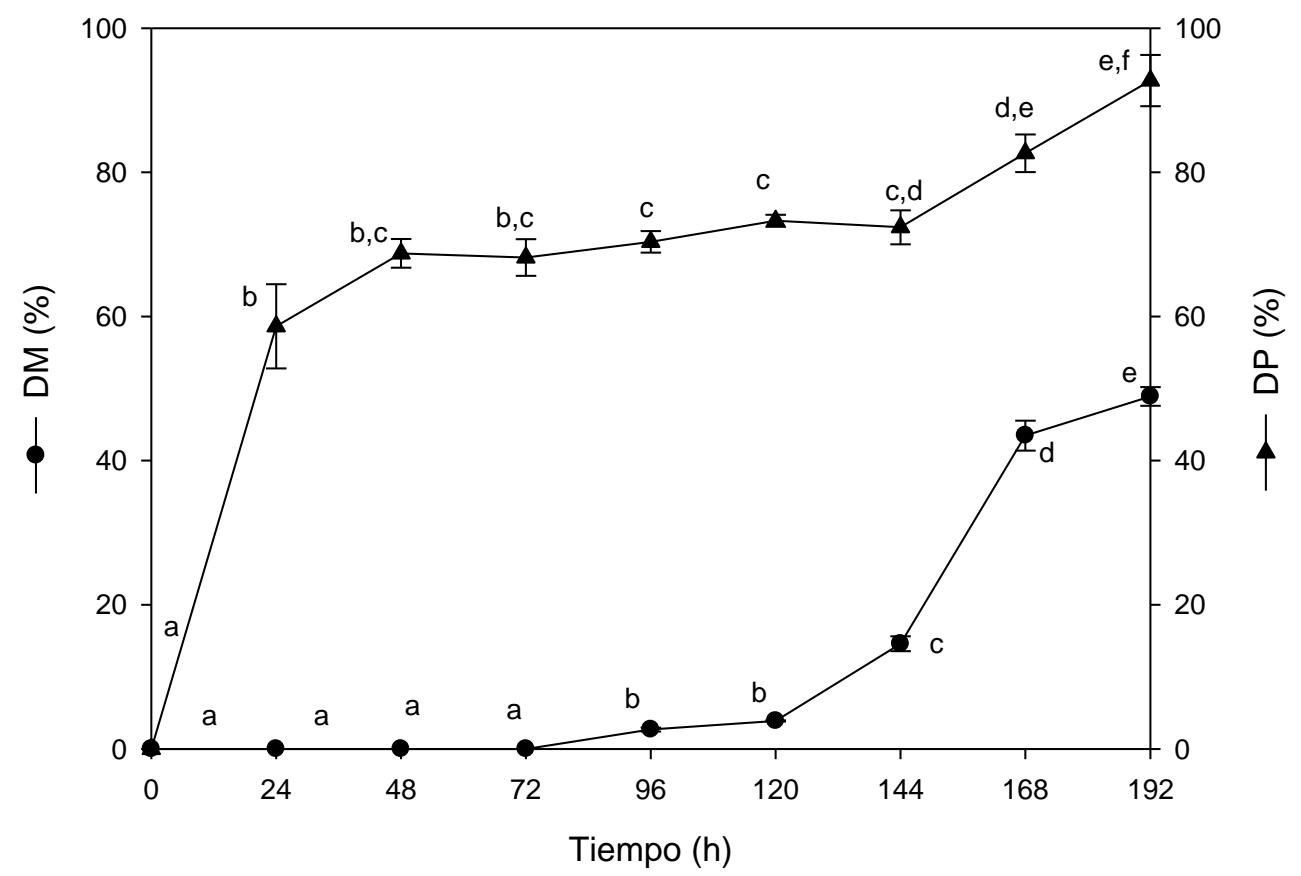

Fig. 19. DM y DP de la repetición del cultivo $\mathrm{L} / \mathrm{R} 10^{7}$ sobre $8 \mathrm{Kg}$ de $\mathrm{DC}$ realizando determinaciones cada $24 \mathrm{~h}$. Letras distintas indican grupos significativamente diferentes (Tukey-Kramer $\mathrm{p}<0.05$ ).

Otro aspecto es que el área disponible en el reactor de acero inoxidable en el cultivo mayor es distinta al área presente en los cultivos tipo Koji (Matraz Erlenmeyer), lo que pudó ser otro factor limitante para el intercambio de los acidos orgánicos producidos en el 
RESULTADOS Y DISCUSIÓN

cultivo y su reacción con el $\mathrm{CaCO}_{3}$ en los DC. La DP igualmente presentó un comportamiento distinto al cultivo pequeño, ya que en el cultivo tipo Koji el aumento de DP es lento hasta las $48 \mathrm{~h}$, mientras que en el cultivo mayor hay un aumento drástico las primeras $24 \mathrm{~h}$. Otro aspecto es que, en el cultivo de $100 \mathrm{~g}$, el aumento de DP es constante hasta las 168 h, no teniendo diferencia significativa con la DP a las 192 h; mientras que, en el cultivo de $8 \mathrm{Kg}$, la DP se mantiene constante después del aumento de las $24 \mathrm{~h}$ hasta las 144 h, después de las cuáles vuelve a aumentar no habiendo diferencia significativa entre las 168 h y 192 h. A pesar de que el comportamiento de remoción de proteína es diferente teniendo mayor cantidad de DC, la DP final de 92\% es similar al 96\% del cultivo tipo Koji, siendo mayor la DP en el cultivo de $8 \mathrm{Kg}$ si se toma en cuenta que el porcentaje de proteína residual fue de $0.7 \%$ en comparación con el $1 \%$ del cultivo a menor escala. Esto se debe a que, al igual que el porcentaje de minerales, el porcentaje de proteína de los DC utilizados en el cultivo de $8 \mathrm{Kg}$ fue menor (30\%) que el de los DC utilizados para el cultivo tipo Koji (35\%).

De acuerdo con los resultados obtenidos, se logró obtener un lote mayor de quitina purificada mediante el proceso de inoculación sucesiva de microorganismos sobre $8 \mathrm{Kg}$ de DC, obteniendo quitina calcárea (13\% cenizas residuales) con porcentaje de proteína residual aceptable, que puede ser desmineralizada con poca concentración de ácido para remover los minerales residuales.

\subsubsection{Caracterización de la quitina obtenida en el escalamiento mediante viscosimetría, RMN $H^{1}$ y Microscopia Electrónica de Barrido}

Una vez que se comprobaron los porcentajes de DM y DP, la quitina calcárea fue desmineralizada químicamente con $\mathrm{HCl} 0.5 \mathrm{~N}$, logrando obtener $1 \%$ de minerales residuales. La quitina obtenida fue caracterizada mediante determinación de PM por viscosimetría y DA por $\mathrm{RMN} \mathrm{H}^{1}$ para comprobar que el método de extracción biológica mantiene las características de la quitina. El PM determinado por viscosimetría fue de 3,693 KDa con un porcentaje de solubles de 9.66\%, por lo que el alto PM de la quitina se mantuvo al utilizar el cultivo L/R $10^{7}$ sobre $8 \mathrm{Kg}$ de DC. El DA fue de $94.10 \%$, resultado 


\section{RESULTADOS Y DISCUSIÓN}

similar al obtenido en el cultivo tipo Koji, por lo que el grado de acetilación tampoco se vio afectado al utilizar mayor cantidad de DC.

Las micrografías (Figura 20) obtenidas por Microscopia Electrónica de Barrido (SEM) muestran el resultado de la purificación mediante cultivo. Pueden observarse las fibras entretejidas formadas por agregados de nanofibrillas, evidenciando la remoción de proteína, a pesar de que hay zonas donde los aglomerados de $\mathrm{CaCO}_{3}$ son visibles, los cuales son resultado de la baja DM obtenida mediante la reacción con los ácidos orgánicos.

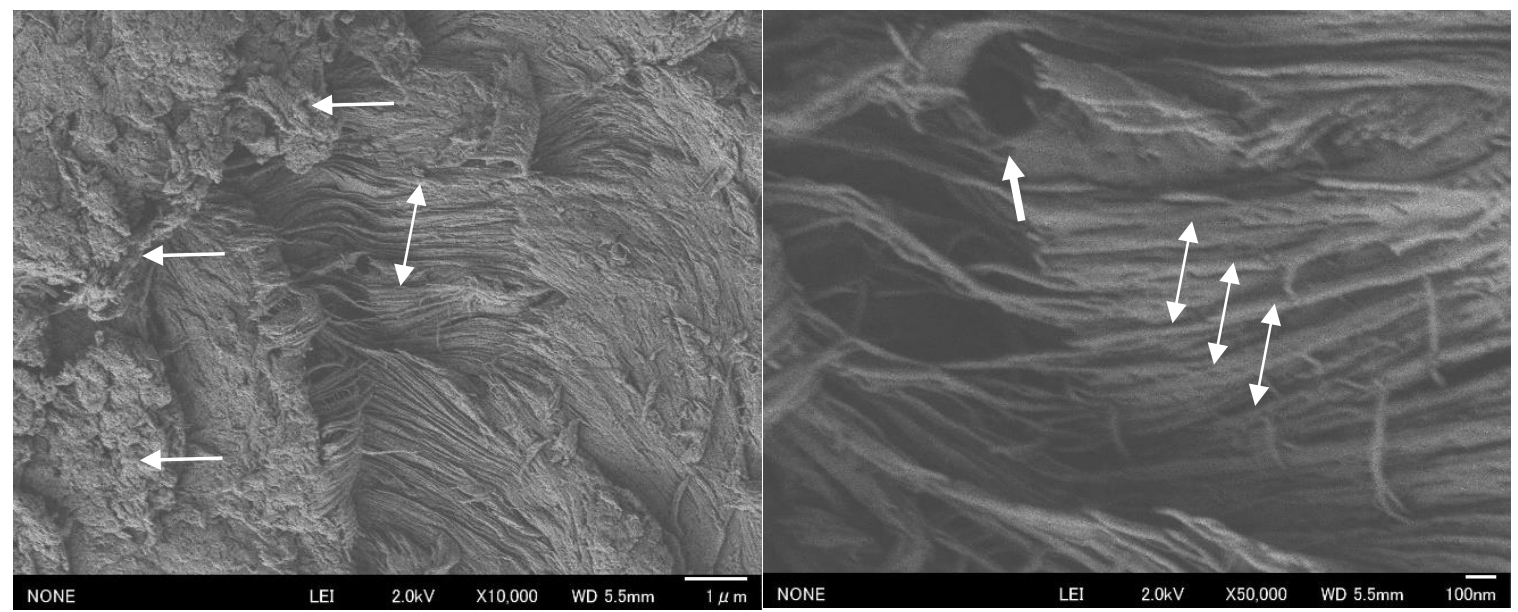

Fig. 20. Micrografías de quitina de la repetición del cultivo L/R10 7 sobre $8 \mathrm{Kg}$ de DC obtenidas por SEM a diferentes objetivos: a) 10000x, b)50000x. Las flechas delgadas, gruesas y de doble sentido señalan minerales, poros y fibras entrelazadas respectivamente (Aranday-García et al., 2017).

8.2.2. Conclusiones parciales sobre la utilización del cultivo L/R $10^{7}$ sobre $8 \mathrm{Kg}$ de DC. La inoculación sucesiva sobre $8 \mathrm{~kg}$ de DC, en el que se obtuvieron $647 \mathrm{~g}$ en peso seco, fue efectiva para la extracción biológica de quitina, generando un biopolímero con alto PM y DA, eliminando el uso de álcalis para remover la proteína presente en los desperdicios y permitiendo el aprovechamiento de otros productos, como hidrolizados proteicos y pigmentos. La quitina purificada presenta las características necesarias para su desacetilación a quitosano, lo que a su vez producirá un quitosano de alto PM. Igualmente, la quitina puede ser tratada mecánicamente para la obtención de 


\section{RESULTADOS Y DISCUSIÓN}

nanofibrillas, las cuáles al proceder de quitina extraída biológicamente, pueden presentar distintas características a las nanofibrillas obtenidas de quitina purificada químicamente.

\subsection{Fibrilación mediante tratamiento mecánico de quitinas extraídas biológicamente.}

\subsubsection{Comparación de quitina caracterizada previamente de acuerdo con el proceso de extracción.}

Las muestras de quitina extraída biológicamente (LR, proveniente del mayor lote de quitina obtenido mediante el cultivo $L / R 10^{7}$ y L, proveniente de una fermentación escala Planta Piloto utilizando a L. brevis como único microorganismo) fueron posteriormente decoloradas con el fin de obtener quitina más blanca. La quitina del método de extracción LR fue decolorada inicialmente con peróxido de hidrógeno al 10\% en proporción 1:10 $(p / v)$, y posteriormente se repitió el proceso de decoloración utilizando hipoclorito de sodio. La quitina del método de extracción L fue únicamente decolorada con hipoclorito de sodio. El PM de las muestras de quitina L y LR (Tabla 6) fue significativamente más alto en la muestra proveniente del tratamiento L, lo que se debe al proceso de decoloración extra que se llevó a cabo sobre la quitina del método LR, pues el PM original de 4,273 KDa se redujo a 1,371 $\mathrm{KDa}$. Sin embargo, todas las muestras obtenidas con métodos biológicos, sin importar el proceso de decoloración usado para obtener quitina más blanca, presentaron un PM superior al de la quitina comercial, indicando que el proceso de extracción mediante cultivo con microorganismos es más efectivo para mantener las características de la quitina.

A pesar de que la decoloración en las muestras biológicas de quitina aparentemente no afectó el PM, si se observa un cambio en el porcentaje de materia soluble, notando que aumenta después del tratamiento con cloro doméstico, por lo que, aunque no haya disminución del PM, sí hay una depolimerización de la cadena de quitina, lo que se puede deberse a la acción del hipoclorito de sodio sobre los puentes de hidrógeno de la cadena, lo cuales son responsables de la baja solubilidad del polímero. 


\section{RESULTADOS Y DISCUSIÓN}

Tanto los valores de DA, como los de cristalinidad son altos y corresponden a reportes previos de quitina; sin embargo, la acetilación disminuye en las muestras biológicas de quitina después del tratamiento con hipoclorito de sodio, resultado similar a lo previamente reportado por Seoudi y Nada en 2007, quienes encuentran que el uso de hipoclorito disminuye el contenido de grupos acetilo.

Tabla 6. Caracterización de quitina de acuerdo con el método de obtención, proceso de decoloración y su comparación con quitina comercial

\begin{tabular}{ccccccc}
\hline Quitina & PM (kDa) & $\begin{array}{c}\text { Solubles } \\
\text { (\%) }\end{array}$ & $\begin{array}{c}\text { DA } \\
\text { (\%) }\end{array}$ & $\begin{array}{c}\text { Minerales } \\
\text { residuales } \\
(\%)\end{array}$ & $\begin{array}{c}\text { Proteína } \\
\text { residual (\%) }\end{array}$ & $\begin{array}{c}\text { Cristalinidad } \\
\text { relativa } \\
\text { (\%) }\end{array}$ \\
\hline L & $1,938 \pm 77^{\mathrm{d}}$ & 12.75 & $92.5 \pm 0.54^{\mathrm{b}}$ & $1.71 \pm 0.47^{\mathrm{d}}$ & $1.10 \pm 0.072^{\mathrm{a}}$ & $95.59 \pm 4.3^{\mathrm{a}}$ \\
LR & $1,371 \pm 34^{\mathrm{b}}$ & 19.30 & $94.10 \pm 0.36^{\mathrm{c}}$ & $0.86 \pm 0.07^{\mathrm{c}}$ & $0.79 \pm 0.32^{\mathrm{a}}$ & $89.7 \pm 3.84^{\mathrm{a}}$ \\
$\mathbf{L}$ & $1,791 \pm 13^{\mathrm{c}}$ & 29.69 & $91.94 \pm 0.48^{\mathrm{b}}$ & $0.41 \pm 0.05^{\mathrm{b}}$ & $1.12 \pm 0.09^{\mathrm{a}}$ & $89.51 \pm 6.74^{\mathrm{a}}$ \\
blanqueado & & & & & & \\
LR & & & & & & \\
blanqueado & $1,500 \pm 44^{\mathrm{b}}$ & 34.23 & $90.64 \pm 0.34^{\mathrm{a}}$ & $0.17 \pm 0.05^{\mathrm{a}}$ & $1.01 \pm 0.18^{\mathrm{a}}$ & $87.03 \pm 2.63^{\mathrm{a}}$ \\
Química & & & & & & \\
(comercial) & $1,133 \pm 62^{\mathrm{a}}$ & 16.31 & $95.41 \pm 0.58^{\mathrm{d}}$ & $0.2 \pm 0.07^{\mathrm{a}}$ & $0.94 \pm 0.05^{\mathrm{a}}$ & $89.23 \pm 1.62^{\mathrm{a}}$ \\
\hline
\end{tabular}

Letras distintas en cada variable (columna) indican que los tratamientos pertenecen a grupos significativamente diferentes entre ellos (Tukey-Kramer $\mathrm{p}<0.05$ ).

La proteína residual no presenta cambios en las muestras biológicas, no habiendo diferencia significativa entre ellas con la muestra comercial; sin embargo, los minerales residuales disminuyeron significativamente en las quitinas de los métodos $L$ y LR (obtenida mediante cultivo con $L$. brevis y $R$. oligosporus) después del blanqueado, siendo ésta última quitina la que no mostró diferencia con el porcentaje de proteína residual de la quitina química. Esto indica que la decoloración no sólo mejora las características visibles de la quitina, sino que también contribuye a la reducción de minerales residuales. Al caracterizar las muestras mediante IR (Figura 21), se observaron las bandas características de la quitina, sin embargo, se observó la presencia de una banda a 2530 $\mathrm{cm}^{-1}$, la cual sólo se encuentra en la quitina proveniente del método $\mathrm{L}$, el cual cuenta con 
RESULTADOS Y DISCUSIÓN

mayor porcentaje de minerales residuales (Tabla 6), por lo que puede ser una banda correspondiente a calcita (Rahman y Halfar, 2014). Otro aspecto es que la región cercana a los $2900 \mathrm{~cm}^{-1}$ fue diferente en todas las muestras. Las bandas en esta región se han reportado como indicadoras del DA (Kassai, 2008), lo que coincide con los valores de DA presentados en la tabla 6 . Estos resultados también se relacionan con la información obtenida por análisis de $\mathrm{RMN} \mathrm{H}^{1}$, cuyos espectros (Anexo III) muestran dos picos entre 2.0-2.1 ppm correspondientes al $\mathrm{H}$ del $\mathrm{CH}_{3}$, los cuales cambian en las quitinas de los métodos L y LR antes y después de la decoloración, difiriendo también de la quitina comercial. Esto puede deberse a la proporción de formas $\alpha$ - y $\beta$-dentro de las cadenas de quitina, las cuales difieren por la fuerza del puente de hidrógeno entre el $\mathrm{OH}(\mathrm{C} 1)-\mathrm{C}=\mathrm{O}$, siendo la $\alpha$ - la más fuerte (u-Chien et al., 2011).

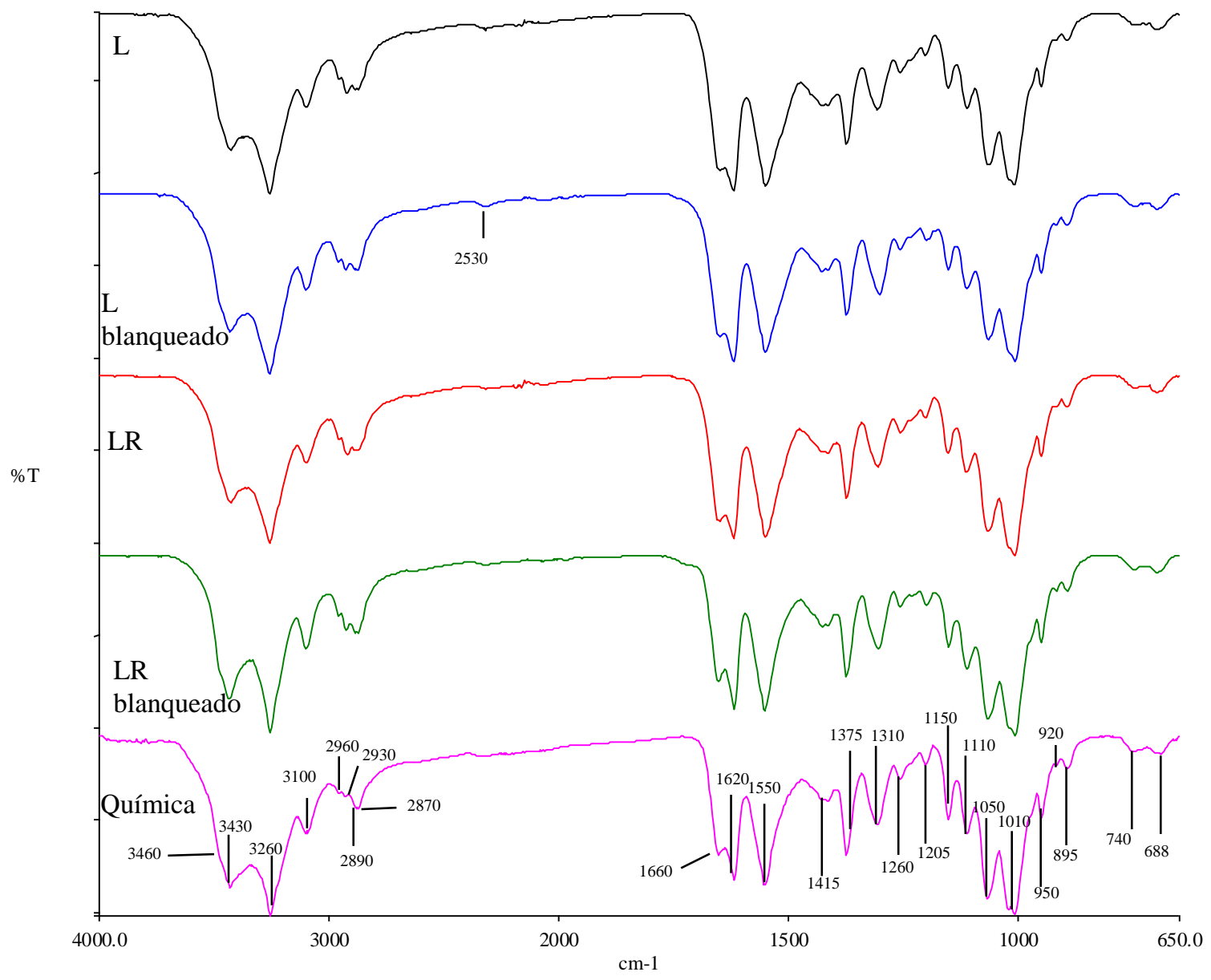

Fig. 21. Espectros infrarrojos de muestras de quitina de los métodos $L$ y $L R$, antes y después de la decoloración, y su comparación con quitina comercial (Química). 
RESULTADOS Y DISCUSIÓN

La caracterización mediante SEM (Figura 22) muestra el efecto del blanqueado, observándose que después del mismo las fibras en las hojuelas de quitina de los métodos biológicos son más delgadas y menos entrelazadas, por lo que la fibrilación para obtener nanofibrillas debe facilitarse. Otro aspecto es que antes de la decoloración pueden observarse aglomerados de minerales, los cuáles desaparecen después del tratamiento con hipoclorito de sodio, lo que coincide con la información de minerales residuales presentados en la tabla 6.

\section{Hojuela Hojuela blanqueada}

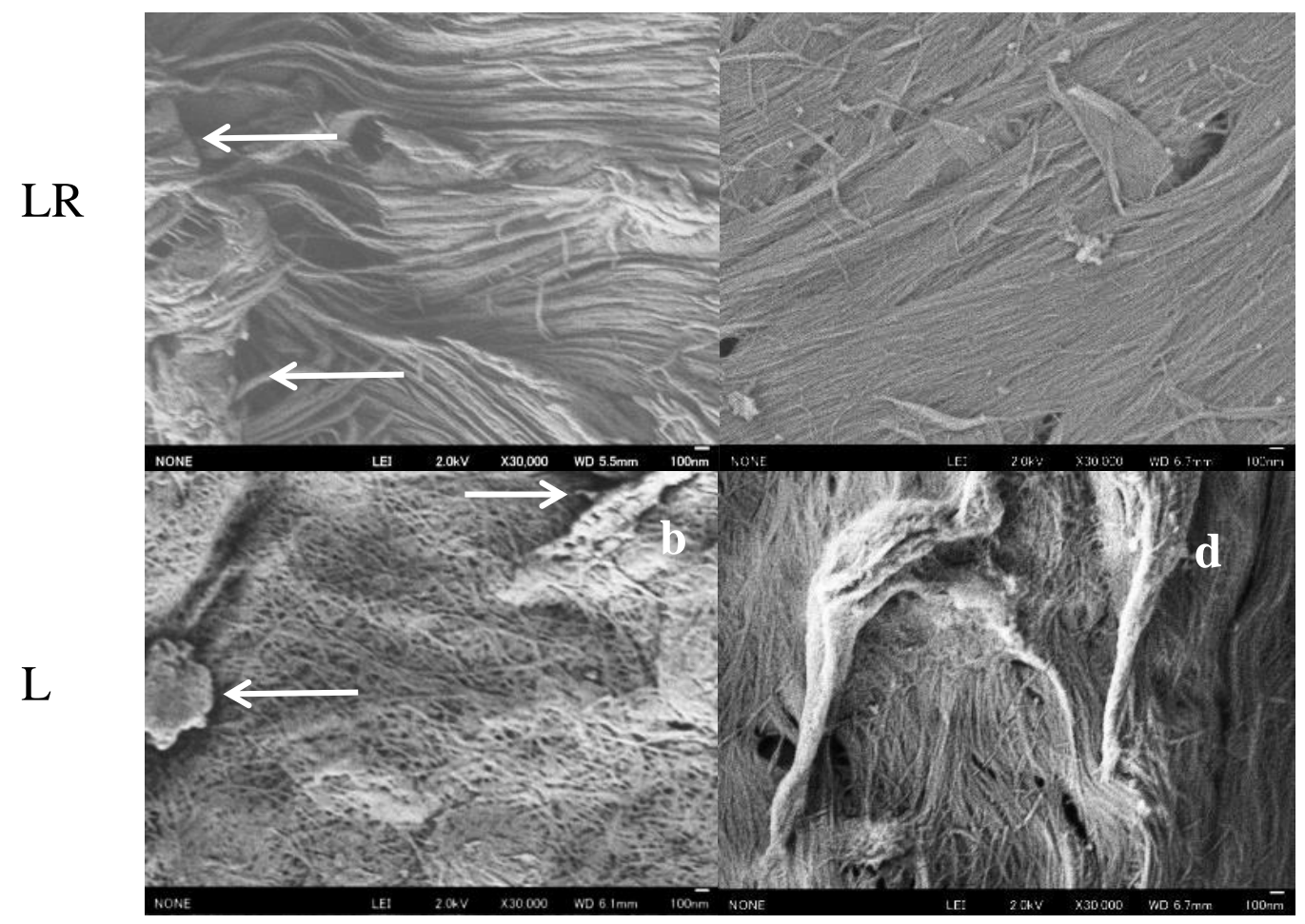

Fig. 22. Micrografías obtenidas por SEM en objetivo 30000x de muestras de hojuelas de quitina de los métodos biológicos LR a) Antes de decoloración, c) Después de decoloración y L b) Antes de decoloración y d) Después de decoloración. Las flechas señalan los minerales residuales.

De acuerdo con los resultados obtenidos, las quitinas obtenidas por métodos biológicos presentan las mismas características que la quitina comercial, como son alto DA y cristalinidad; sin embargo, tienen la ventaja de tener un mayor PM, lo que puede 
RESULTADOS Y DISCUSIÓN

conferirles diferentes propiedades al momento de su fibrilación para obtención de nanofibrilla.

\subsubsection{Viscosidad y transmitancia de las suspensiones de nanofibrillas de quitina} (NFQ)

Una vez que las hojuelas de quitina fueron caracterizadas, se procedió a su fibrilación como se describe en la sección 7.3.2. Las suspensiones obtenidas fueron almacenadas después de remover burbujas de aire mostrando estabilidad superior a 5 meses.

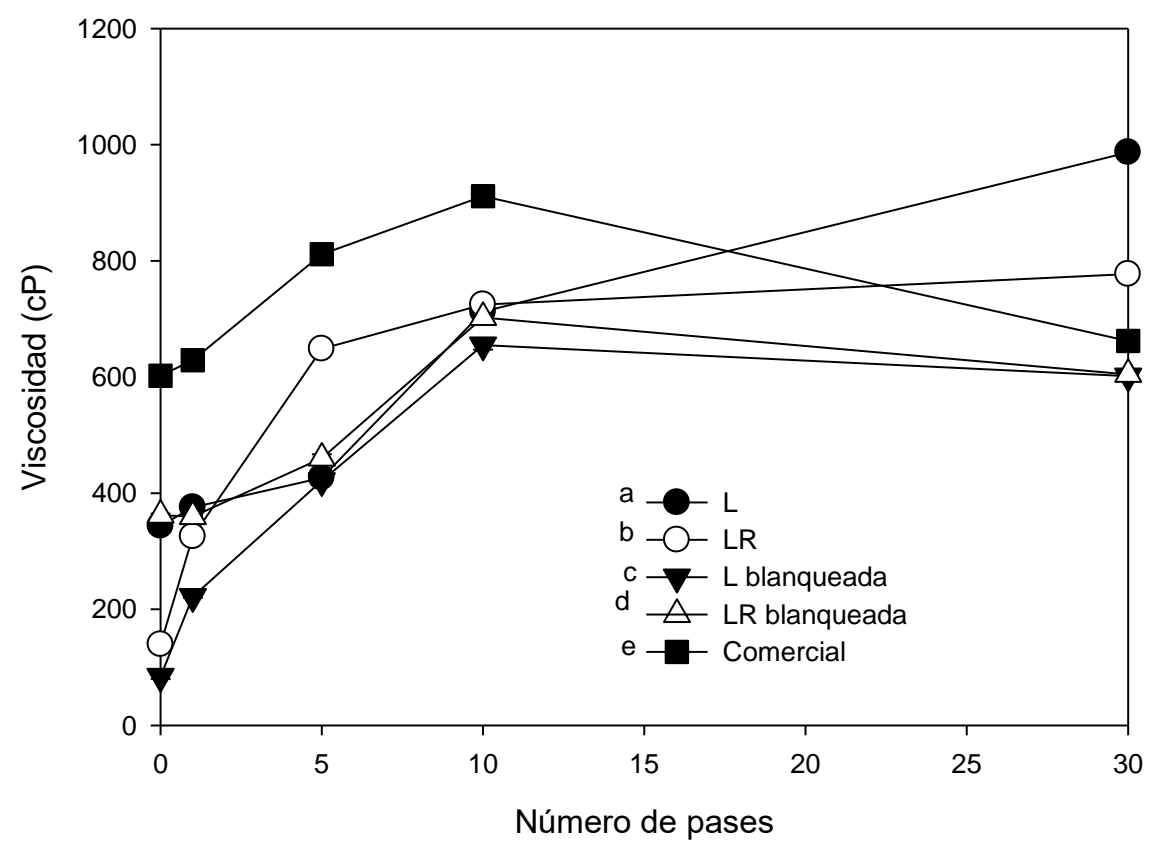

Fig. 23. Viscosidad de las suspensiones de NFQ de los métodos $L$ y $L R$ de acuerdo con los pases a través del sistema Star Burst y su comparación con quitina química. Letras distintas junto a la leyenda indican si los valores de viscosidad de las NFQ a los 10 pases pertenecen a grupos significativamente diferentes entre tratamientos (Tukey-Kramer $\mathrm{p}<0.05)$. La viscosidad más alta a los 10 pases esta indicada por la letra e señalando la quitina comercial.

La viscosidad de las suspensiones (Figura 23) mostró un aumento en todos los tipos de quitina conforme aumentaban los pases a través del sistema Star Burst, comenzando a disminuir después de los 10 pases, a excepción de las muestras biológicas sin blanqueado, 
RESULTADOS Y DISCUSIÓN

que continúan aumentando hasta los 30 pases. Por lo anterior, la quitina fue completamente fibrilada en las muestras L y LR blanqueadas, así como la quitina química con tan sólo 10 pases. Esto se debe a que una vez que se alcanza una fibrilación completa, la viscosidad comienza a disminuir debido a que las nanofibrillas se vuelven más delgadas y se rompen, evitando así el entrecruzado entre fibras, disminuyendo a su vez la viscosidad.

También se observa que el tratamiento con hipoclorito de sodio, como se mostró en la caracterización por SEM, contribuye al adelgazamiento de fibras y disminución del entrecruzado, facilitando la fibrilación de las hojuelas. La viscosidad de todos los tratamientos a los 10 pases fue significativamente distinta debido a la baja desviación estándar entre mediciones, siendo mayor en la quitina química y menor en la quitina L blanqueada.

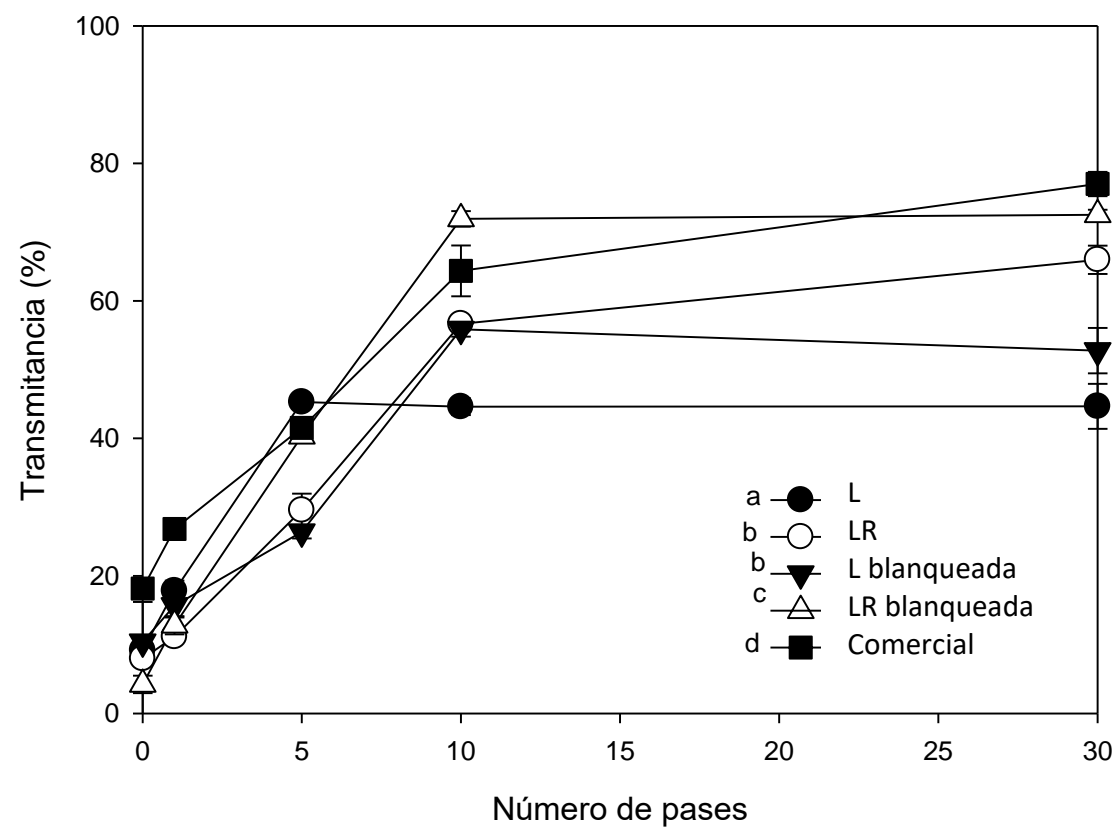

Fig. 24. Transmitancia de las suspensiones de NFQ de los métodos $L$ y $L R$ de acuerdo con los pases a través del sistema Star Burst y su comparación con quitina química. Letras distintas junto a la leyenda indican si los valores de transmitancia de las NFQ a los 10 pases pertenecen a grupos significativamente diferentes entre tratamientos (TukeyKramer $p<0.05)$. La transmitancia más alta a los 10 pases esta indicada por la letra $c$ señalando la quitina LR blanqueada. 


\section{RESULTADOS Y DISCUSIÓN}

La transparencia de las suspensiones esta igualmente relacionada con la fibrilación de la quitina, pues mientras las fibras se vuelvan más delgadas, mayor será la transmitancia. En la figura 24 se observa que únicamente la quitina del método $L$ sin decoloración presenta la máxima transmitancia a los 5 pases, permaneciendo constante hasta 30 pases. Las demás muestras biológicas aumentan su transparencia hasta 10 pases, después de los cuales no hay diferencia significativa. Sólo la transmitancia de la quitina química sigue aumentando hasta 30 pases. A los 10 pases, la suspensión de NFQ del método LR decolorado es significativamente mayor (77\%), seguido de la suspensión de quitina química. Estos resultados coinciden con la viscosidad, por lo que sólo se necesitan 10 pases por el sistema a presión alta para fibrilar por completo la hojuela de quitina. Igualmente, el tratamiento de blanqueado mejora las características de las NFQ.

Los resultados anteriores muestran que las suspensiones provenientes de quitinas $L$ y $L R$ con blanqueado presentan el mismo comportamiento que las suspensiones de quitina química en cuanto a viscosidad, mientras que las suspensiones de quitina LR blanqueada mostraron mayor transmitancia. Sin embargo, los valores más bajos presentados por las suspensiones de nanofibrillas de las demás muestras de quitina biológica son cercanos a pesar de ser estadísitcamente diferentes, por lo que para asegurar un análisis completo de todas las muestras de quitina extraída biológicamente se llevaron a cabo los demás análisis sobre todas las nanofibrillas de métodos biológicos, aumentando la fibrilación en cada tratamiento mediante el método mecánico hasta 100 pases a través del sistema Star Burst, con el fin de asegurar una completa fibrilación y relacionar la morfología con las propiedades de nanofibrillas y películas a base de éstas. Los resultados de cristalinidad, morfología de nanofibrillas, elaboración de películas de nanofibrillas y pruebas mecánicas se compararon con lo previamente reportado para suspensiones de nanofibrillas y películas elaboradas con quitina comercial (extraída químicamente) (Dutta et al., 2013).

\subsubsection{Cristalinidad y Estructura química de las suspensiones de NFQ}

La cristalinidad relativa disminuyó una vez que las hojuelas fueron molidas para preparar la dispersión a utilizar en el sistema Star Burst, de valores arriba del $87 \%$ hasta $74 \%$, 


\section{RESULTADOS Y DISCUSIÓN}

siendo menor en la dispersión de NFQ del método L, la cual llegó a 68\%. Los patrones de difracción (Figura 25), una vez que la quitina fue dispersada en nanofibrillas, dejaron de presentar los picos de intensidad 021, 120, 101 y 130. Cuando la quitina fue pasada por tratamiento mecánico, no hubo diferencia en la cristalinidad relativa, por lo que la cristalinidad de las hojuelas disminuye al fibrilarse, pero no hay cambio al continuar con el tratamiento a presión para fibrilar por completo.

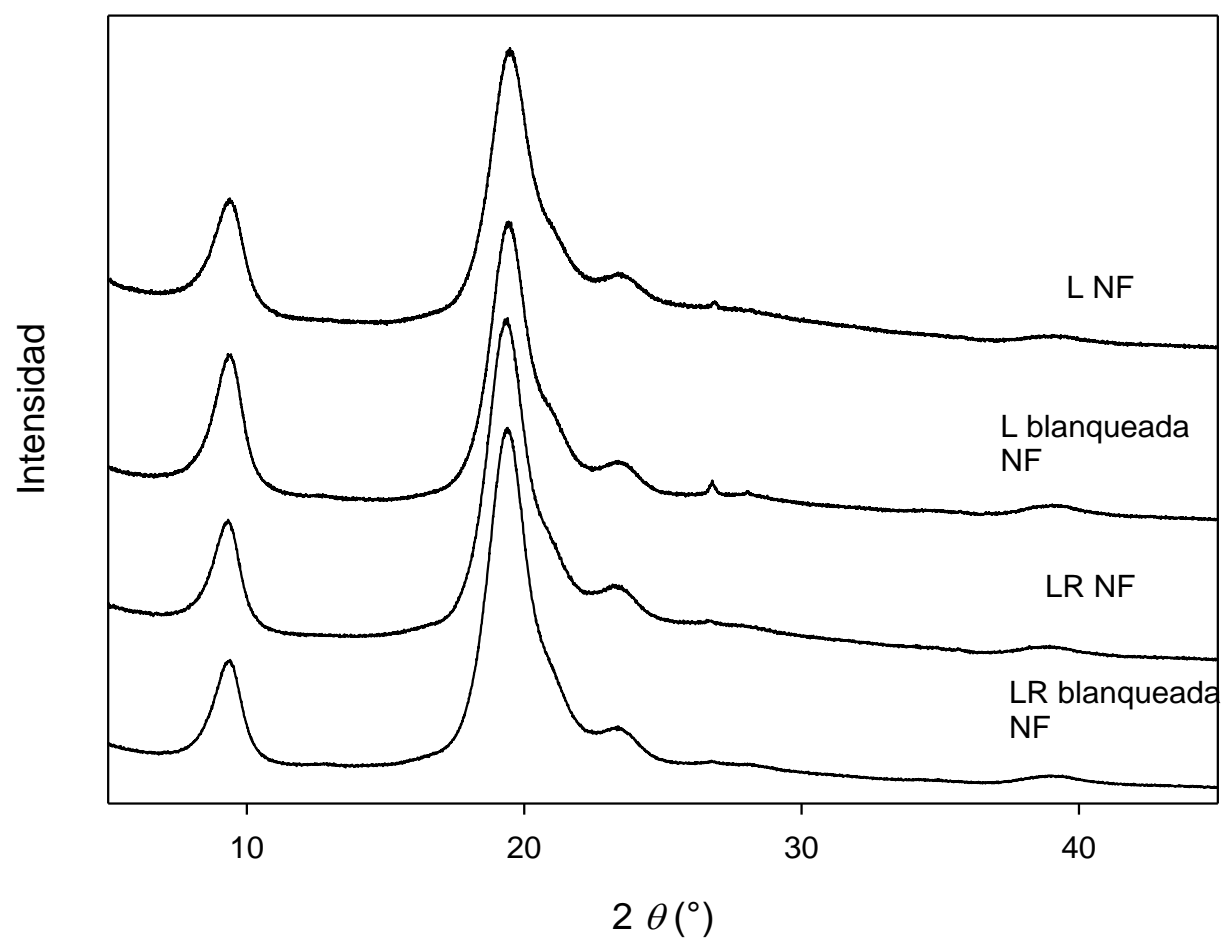

Fig. 25. Patrones de difracción de rayos $X$ de suspensiones de NFQ correspondientes a los métodos $L$ y $L R$ después de dos pases por molino. 


\section{RESULTADOS Y DISCUSIÓN}

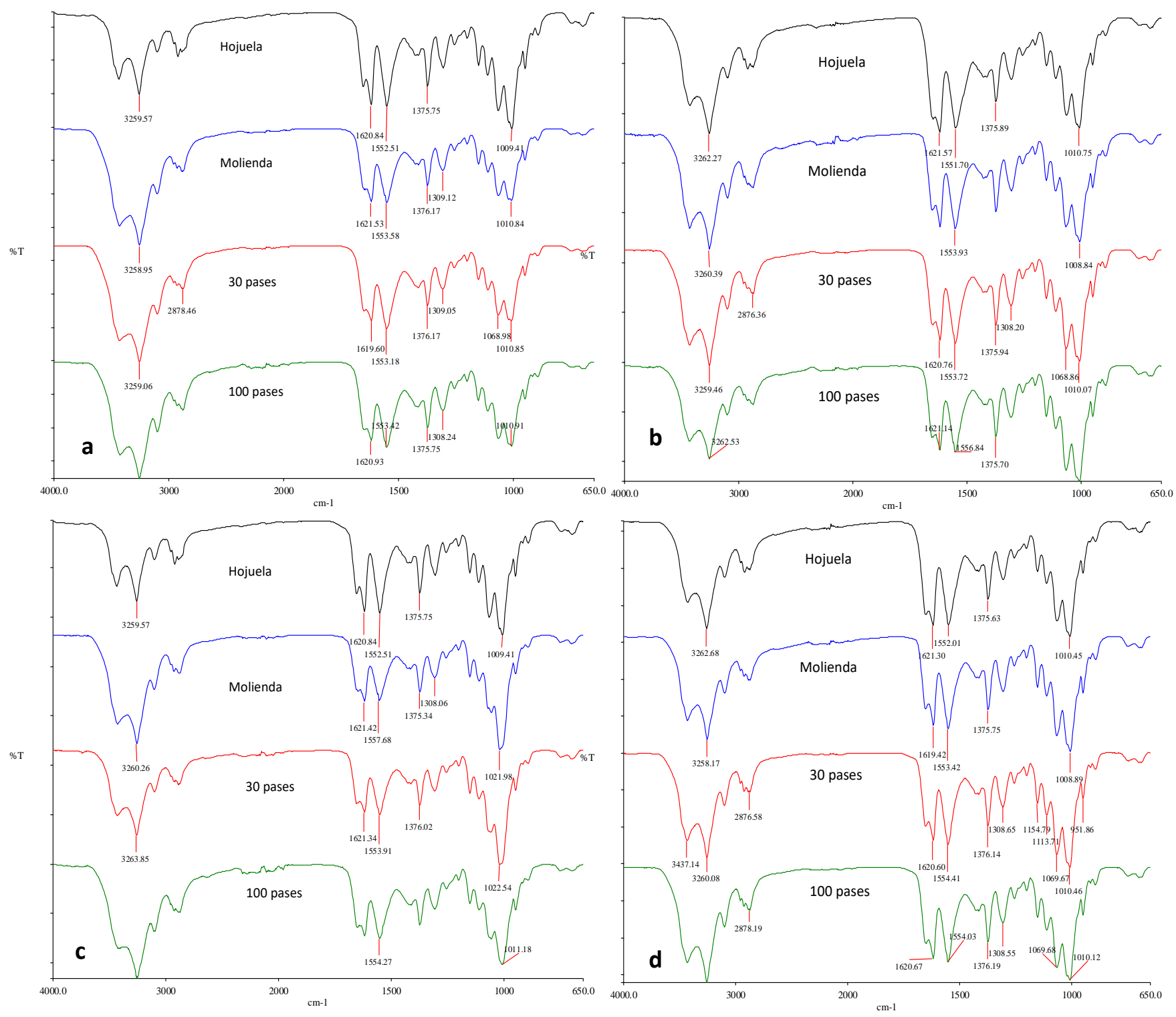

Fig. 26. Espectros infrarrojos de muestras de quitina en hojuela y suspensiones de nanofibrillas después de su molienda en condiciones ácidas, 30 y 100 pases por el sistema Star Burst. a) L, b) L blanqueada, c) LR y d) LR blanqueada

La estructura química, por otra parte, se analizó mediante espectrofotometría infrarroja, con la cual se muestra en los espectros que no hay cambio a pesar del tratamiento mecánico (Figura 26), inclusive hasta 100 pases por el sistema de agua a presión, por lo que es un método seguro para la obtención de nanofibrillas. El blanqueado tampoco fue un factor que alterara la estructura química de las nanofibrillas. 


\section{RESULTADOS Y DISCUSIÓN}

\subsubsection{Caracterización de suspensiones de NFQ mediante SEM}

Desde el momento en que la quitina es pasada por molino en condiciones ácidas, puede notarse un cambio entre la morfología y arreglo de las fibras de quitina. Únicamente con la molienda, el entrecruzamiento de las fibras disminuye, observándose los bucles de fibras formados a su vez por nanofibrillas de quitina. Este efecto es causado por las condiciones ácidas de molienda, lo que provoca la ionización catiónica de los grupos amino en la superficie de la quitina, resultando en una repulsión entre fibras (Ifuku et al., 2009). Al pasar las fibras por el sistema de alta presión una vez, la morfología cambia nuevamente, notándose que las fibras adelagazan y se acortan; además de hacer más evidentes los bucles de nanofibrillas. Después de 10 pases, las fibras de las muestras blanqueadas se observan completamente fibriladas y con un grosor menor de $100 \mathrm{~nm}$, mientras que las fibras de muestras no blanqueadas necesitan 30 pases para presentar esa morfología. En ambos casos, al continuar con el tratamiento a presión, las nanofibrillas no presentan más cambios, indicando que el mínimo de pases necesario para obtener una completa fibrilación es 10 pases para muestras blanqueadas y 30 pases para las muestras sin decoloración. Tal como se observó en los resultados de viscosidad y transmitancia, el uso de cloro para blanquear la quitina permite una mejor fibrilación del biopolímero, necesitando menos pases para la obtención de nanofibrillas. Las micrografías también muestran que las suspensiones de quitina LR (Figura 27) son más fácilmente fibriladas que las obtenidas de quitina L (Figura 28); por lo que el método de obtención por inoculación sucesiva de la bacteria láctica y el hongo proteolítico es más recomendable para la obtención de nanofibrillas que la inoculación de un solo microorganismo. Esto puede deberse a que el método L involucra una desproteinización química junto con la desmineralización química (tratamiento no necesario en el método $L R$ ), con el fin de remover por completo otros componentes y asegurar la purificación de la quitina, tratamiento que puede ser un factor para dificultar la fibrilación. 


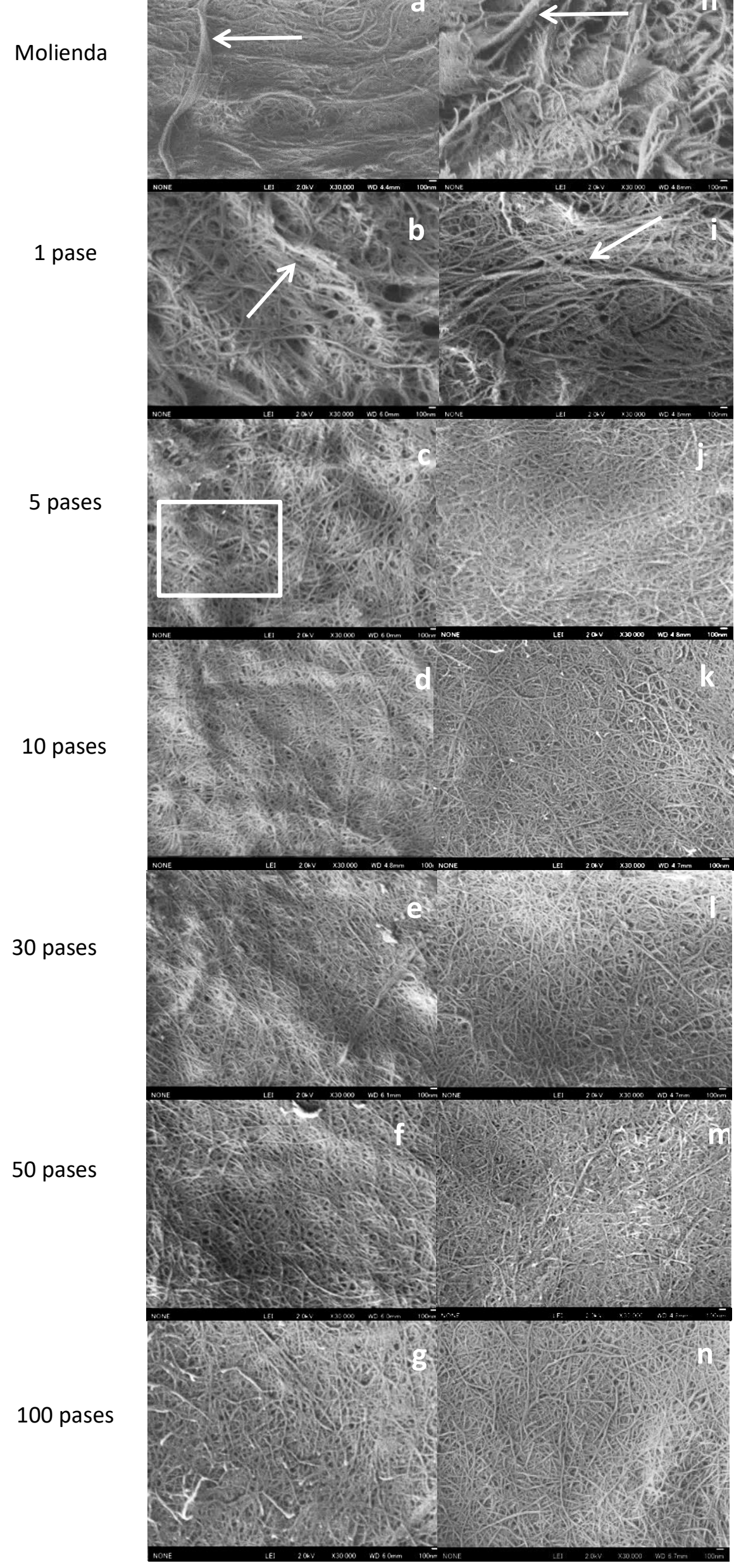

Fig. 27. Micrografías obtenidas por SEM en objetivo 30000x de suspensiones de NFQ del método LR después de distintos pases por el sistema Star Burst. Incisos a-g corresponden a muestras de quitina sin blanqueo. Incisos h-n corresponden a muestras con blanqueo. Las flechas señalan los bucles de nanofibras. 

$\mathrm{L}$
L blanqueada

Molienda

1 pase

5 pases

10 pases

30 pases

50 pases

100 pases
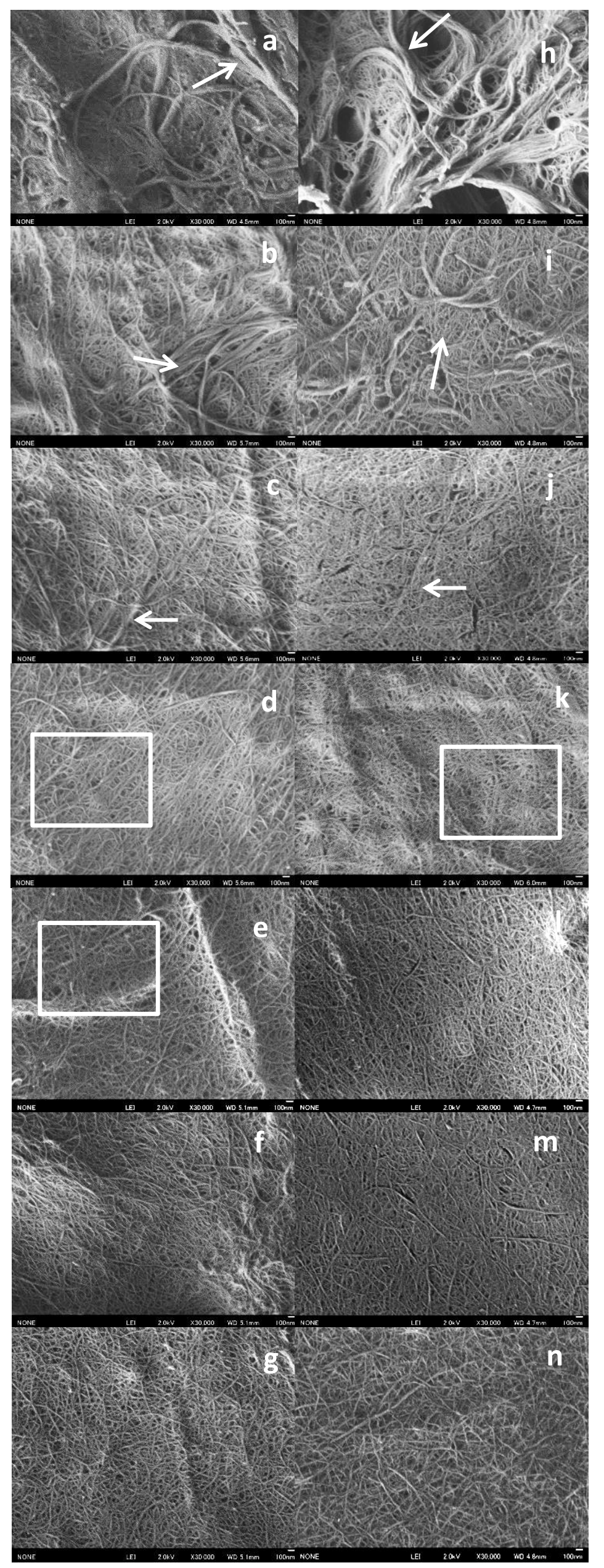

RESULTADOS Y DISCUSIÓN

Fig. 28. Micrografías obtenidas por SEM en objetivo 30000x de suspensiones de NFQ del método $L$ después de distintos pases por el sistema Star Burst. Incisos a-g corresponden a muestras de quitina sin blanqueo. Incisos h-n corresponden a muestras con blanqueo. Las flechas señalan los bucles de nanofibras. 


\section{RESULTADOS Y DISCUSIÓN}

Otro aspecto que tomar en cuenta fue la sonicación de las suspensiones de NFQ, con lo que se buscó aumentar la transparencia de las películas de nanofibrillas. Las micrografías (Fig. 29) muestran el efecto de la sonicación, notándose el aumento de poros y espacio entre las fibras, lo que repercute al momento de elaborar las películas. Cuando las suspensiones son filtradas y prensadas a $100^{\circ} \mathrm{C}$ sin sonicación previa, las nanofibrillas forman una configuración "alineada" (Figura 29b); sin embargo, al haber sonicación antes de la elaboración de la película las fibras no toman una orientación específica (Figura 29d).

\section{Suspension de NFQ Película de NFQ}

Sin sonicación

Con sonicación

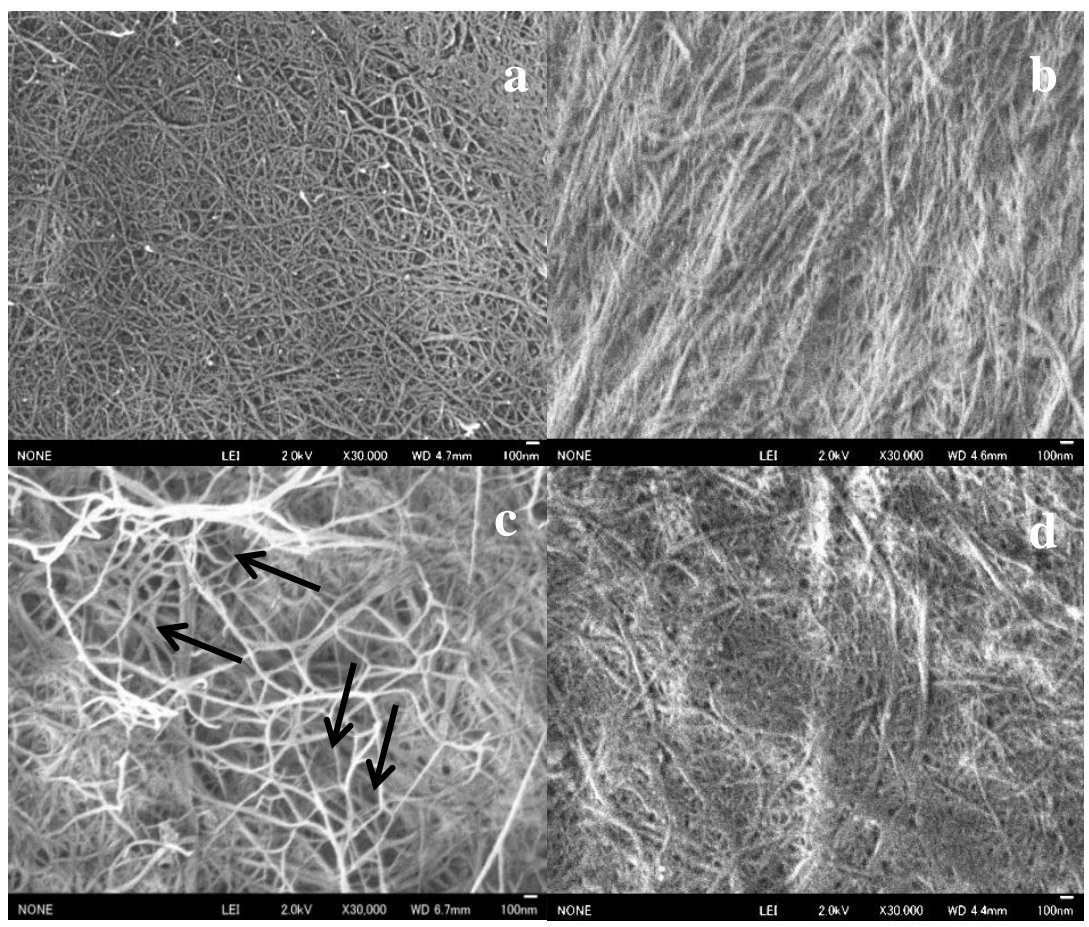

Fig. 29. Micrografías obtenidas mediante SEM a objetivo 30000x de suspensiones de NFQ a) sin y c) con sonicación previa; y películas de NFQ elaboradas a partir de suspensiones b) $\sin$ y d) con sonicación previa. Las flechas señalan los poros formados por la sonicación.

El cambio en el arreglo de las fibras al sonicar la suspensión se debe a la cavitación, efecto en el que se forman burbujas dentro de la suspensión al mismo tiempo que absorben energía de las ondas emitidas, lo que ocasiona su implosión generando altas presiones y 


\section{RESULTADOS Y DISCUSIÓN}

choque de ondas que afectan los puentes de hidrógeno y fuerzas de Van der Waals entre las fibras de quitina (Lu et al., 2013).

\subsubsection{Transmitancia y propiedades mecánicas de películas de NFQ}

Las películas de NFQ del método LR con blanqueado y sonicación obtuvieron la mayor transmitancia a los 10 pases, alcanzando un $22 \%$ mientras que las muestras no sonicadas permanecieron debajo de $18 \%$ (Figura 30 ). Las películas blanqueadas del tratamiento L, con y sin sonicación, tuvieron una transmitancia menor del 10\%; por lo que la sonicación previa de las suspensiones de quitina aumenta la transparencia debido a la desintegración de los agregados de nanofibrillas de quitina (Lu et al., 2013). Las muestras del método LR, sin importar el proceso de blanqueado o sonicación, presentaron mayor transparencia, resaltando que el uso del hongo en la extracción de quitina resulta en una mayor purificación. Sin embargo, aun cuando hubo un aumento en la transmitancia de las muestras debido al blanqueado y sonicación, el porcentaje fue menor al que se obtiene en películas elaboradas con nanofibrillas de quitina química (Dutta et al., 2013).
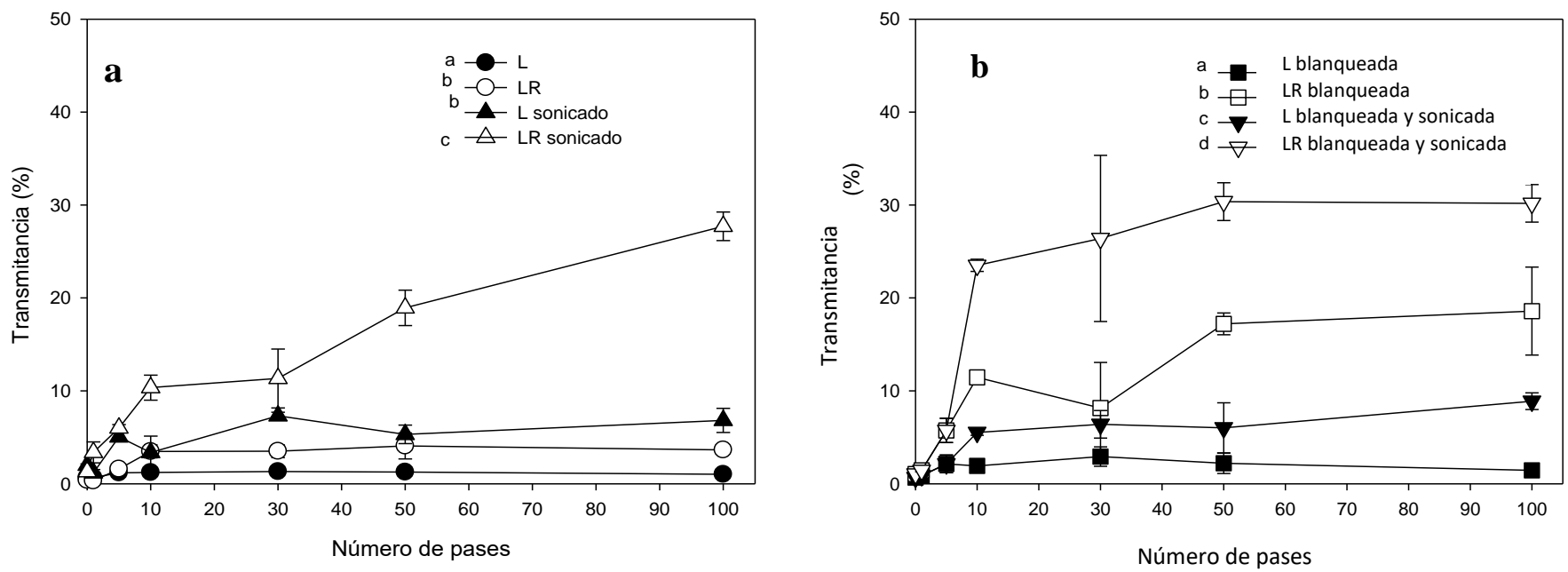

Fig. 30. Efecto de la sonicación en la transmitancia de películas de nanofibrillas de quitina a lo largo de pases por el sistema de alta presión (Star Burst). a) Muestras sin blanqueo y b) Muestras blanqueadas. Letras distintas junto a la leyenda indican que la transmitancia a los 10 pases es significativamente diferente entre los tratamientos (Tukey-Kramer $p<0.05$ ). 


\section{RESULTADOS Y DISCUSIÓN}

La baja transparencia a $600 \mathrm{~nm}$ pudo ser resultado del color original de la quitina, ya que comparado con el color blanco de la quitina extraída químicamente, fue ligeramente rojizo, terminando en un tono rosáceo después del proceso de blanqueo. Esto es debido a que los pigmentos pueden estar fuertemente ligados a la cutícula del crustáceo dependiendo de la especie, siendo más fáciles de remover de los residuos de cangrejo que de los desechos de otros crustáceos, dificultando la decoloración (Yeul y Rayalu, 2013). Por lo anterior, es recomendable la remoción total de pigmentos para lograr aumentar la transparencia de las películas; sin embargo, esto puede traducirse en procesos agresivos que pueden disminuir el PM de la quitina.

Las micrografías por SEM de las películas después de la prueba mecánica (Figura 31) muestra cómo las nanofibrillas son estiradas debido a la fuerza aplicada, por lo que las fibras entrecruzadas pueden ser estiradas hasta su máxima longitud, dando elasticidad a las películas. Esto también explica el por qué el módulo elástico se mantiene después de los 10 pases por el sistema Star Burst, pues es a ese número de pases que la quitina está completamente fibrilada alcanzando su máxima longitud, resultado que coincide igualmente con la viscosidad de las suspensiones.

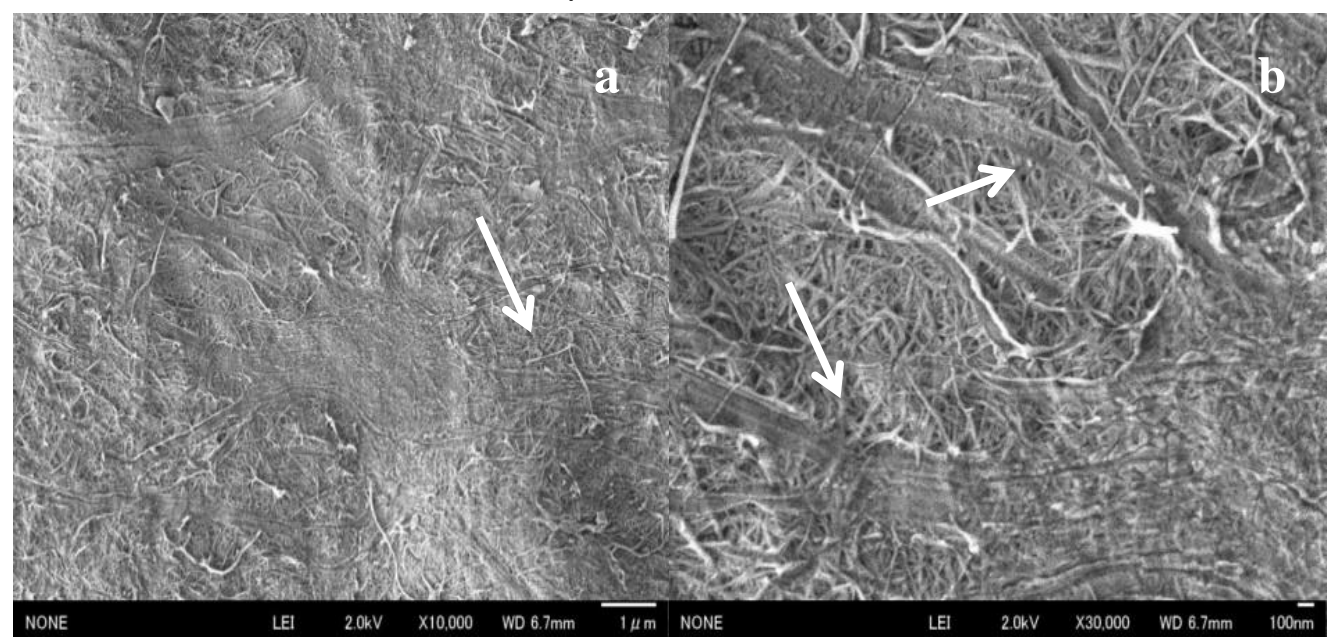

Fig. 31. Micrografía por SEM de la película LR blanqueada y sonicada mostrando el efecto de la fuerza aplicada en las pruebas mecánicas. Las flechas señalan las fibras que fueron "estiradas" después de la prueba.

La fuerza de tensión (Figura 32) no tuvo diferencia significativa de acuerdo con los pases por el sistema a presión, por lo que la misma fuerza puede ser alcanzada con uno o 100 


\section{RESULTADOS Y DISCUSIÓN}

pases a pesar de las altas desviaciones estándar presentadas, las cuales pueden deberse a la orientación de las fibras al realizar la prueba mecánica o al grosor de las muestras que podia variar hasta $8 \mu \mathrm{m}$ en una misma película. Otro aspecto por considerar fue que la decoloración de la quitina sí afectó las propiedades mecánicas finales, siendo las películas del tratamiento LR blanqueado las que obtuvieron la mayor fuerza de tensión, alcanzando $56 \mathrm{MPa}$ a los 10 pases, con y sin sonicación.
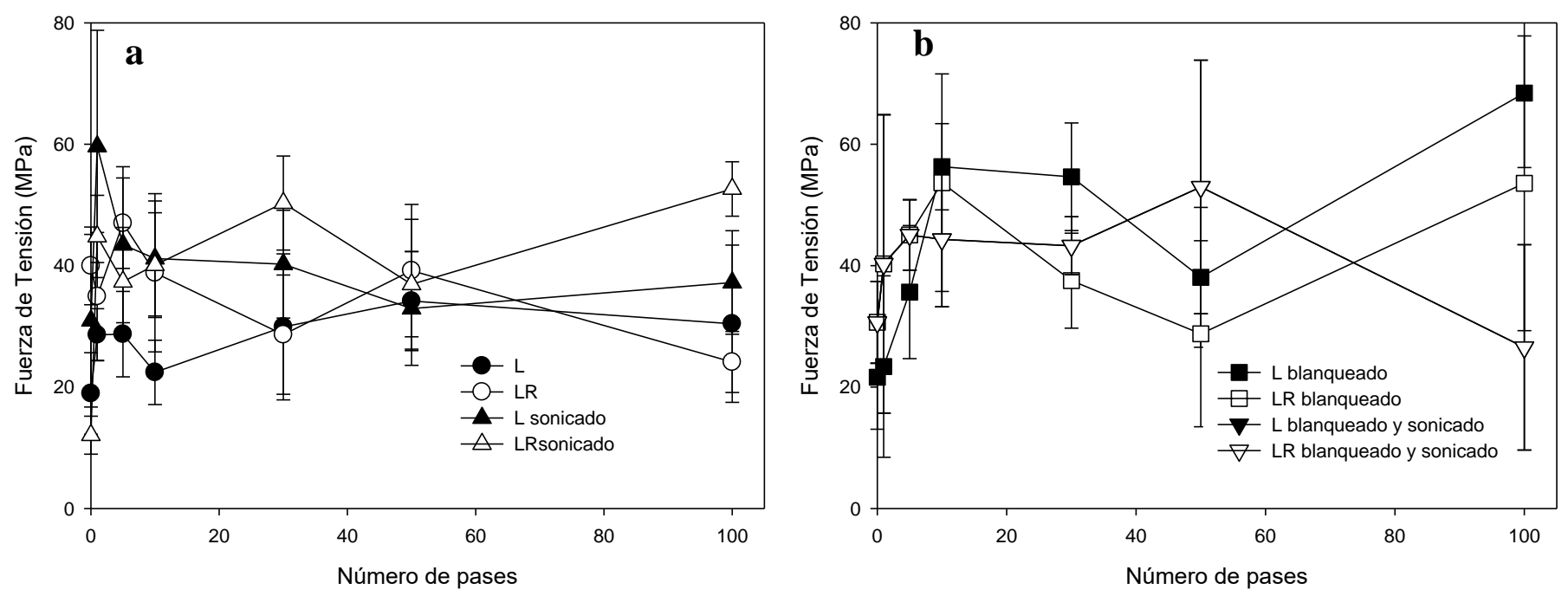

Fig. 32. Fuerza de tensión de películas de nanofibrillas de quitina a través de pases por el sistema Star Burst. a) Muestras sin blanqueo y b) Muestras con blanqueo.

Por su parte, el módulo elástico (Figura 33) fue más alto en las películas LR blanqueadas y sonicadas, llegando a 5,300 $\mathrm{MPa}$, valor superior al reportado para películas de nanofibrillas de quitina química, las cuáles alcanzaron 2,700 MPa (Dutta et al., 2013). Las películas del tratamiento LR presentaron mejores propiedades mecánicas que aquellas del método L, lo que puede deberse al porcentaje de minerales residuales, que fue más alto en la quitina $L$ y está relacionado a la rigidez de la cutícula de crustáceos (Lu et al., 2013). El módulo de Young fue más alto en las películas de quitina biológica que en las provenientes de quitina química, sin importar el blanqueado o sonicación, lo que presenta una ventaja en las posibles aplicaciones de las películas. Considerando que la fuerza de 


\section{RESULTADOS Y DISCUSIÓN}

tensión fue similar a la reportada en películas de quitina química y que el módulo elástico fue mayor, las películas de nanofibrillas de quitina extraída biológicamente son una alternativa para nuevas aplicaciones que requieran alta elasticidad.
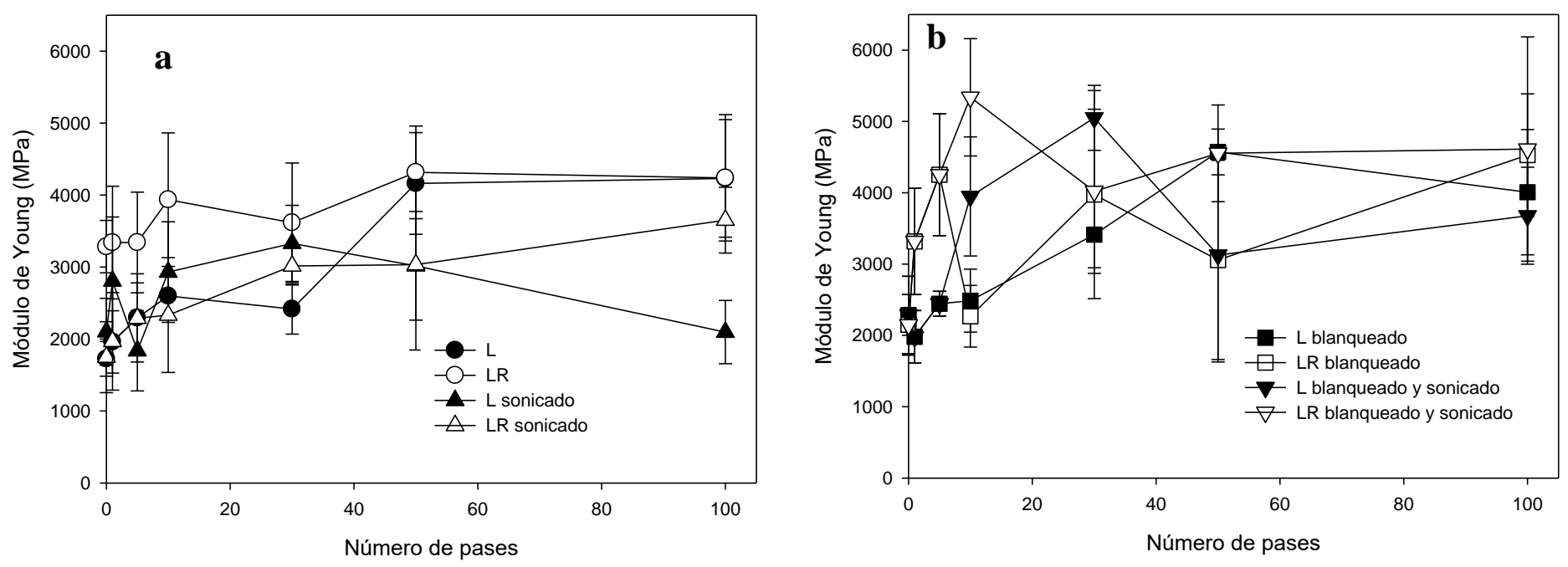

Fig. 33. Módulo de Young de películas de nanofibrillas de quitina a través de pases por el sistema Star Burst. a) Muestras sin blanqueo y b) Muestras con blanqueo.

\subsubsection{Conclusiones parciales sobre la obtención de NFQ y su uso para elaboración de películas.}

Las quitinas extraídas biológicamente presentaron características similares a la quitina comercial, como DA y cristalinidad; sin embargo, el PM fue mayor en las primeras; por lo que el método biológico mantiene las características originales. Por otra parte, el tratamiento de decoloración con hipoclorito de sodio resultó efectivo no solo para blanquear la quitina, sino también para mejorar su proceso de fibrilación, aunque aún es recomendable remover la mayor cantidad de pigmentos con el fin de asegurar una alta transparencia. El tratamiento mecánico en condiciones ácidas fue efectivo para la obtención de nanofibrillas, necesitando solamente 10 pases a través del sistema Star Burst para fibrilar la quitina por completo, aspecto mejorado por el blanqueo. La sonicación de las suspensiones previamente a la elaboración de películas tuvo también un efecto sobre la transmitancia y propiedades mecánicas de las películas, por lo que es mejor combinar el tratamiento de blanqueado junto con la sonicación para incrementar la transparencia de 


\section{RESULTADOS Y DISCUSIÓN}

las películas, así como su módulo elástico. Por lo anterior, utilizar quitina obtenida mediante el método LR es también efectivo para la obtención de nanofibrillas de quitina y la elaboración de películas con alto módulo elástico.

\subsection{Desacetilación de quitina proveniente del mayor lote de quitina obtenido mediante el cultivo L/R $10^{7}$ para la obtención de quitosano.}

\subsubsection{Caracterización mediante espectrofotometría infrarroja}

La desacetilación en condiciones heterogéneas se llevó a cabo durante $3 \mathrm{~h}$, tomando muestras cada hora. El espectro infrarrojo (Figura 34) muestra a $1650 \mathrm{~cm}^{-1}$ la vibración de estiramiento de la amida I, observándose que la banda comienza a disminuir al aumentar el tiempo de reacción. La vibración de estiramiento del $\mathrm{CH}$ se observa a $2870 \mathrm{~cm}^{-1}(\mathrm{vCH})$, banda asignada al anillo de glucosa y que ha sido previamente reportado como un indicador de la desacetilación del quitosano, lo cual concuerda con su incremento al aumentar las horas. Esto indica que al aumentar el tiempo de desacetilación, la fracción acetilada del quitosano disminuye (Fernández-Martín et al., 2014). Las bandas en la región $3400 \mathrm{~cm}^{-1}$ son comúnmente difíciles de diferenciar debido a interferencias del agua; $\sin$ embargo, en los espectros obtenidos pueden distinguirse fácilmente después de 3 horas de reacción. Las vibraciones de estiramiento del hidroxilo $(v \mathrm{OH})$ y el $\mathrm{C}=\mathrm{H}(\mathrm{vCH})$ se observan a $3440 \mathrm{~cm}^{-1}$ y $3460 \mathrm{~cm}^{-1}$, respectivamente. La vibración de estiramiento simétrica y asimétrica del grupo amino $(\mathrm{VNH})$ aparece a $3167 \mathrm{~cm}^{-1}$ y $3250 \mathrm{~cm}^{-1}$. En la región de $2870 \mathrm{~cm}^{-1}$ se observan diferentes bandas relacionadas a las vibraciones de estiramiento simétricas y asimétricas del $-\mathrm{CH}$, correspondientes al anillo $\left(-\mathrm{CH}_{2} \mathrm{OH}\right)$ y al grupo metilo $\left(-\mathrm{CH}_{3}\right)$, mientras que las vibraciones de doblamiento $(\delta \mathrm{CH})$ aparecen en 1375 $\mathrm{cm}^{-1}$. La vibración de doblamiento de la amida II $(\delta \mathrm{NH})$ y del metileno $\left(\delta \mathrm{CH}_{2}\right)$ aparecen en $1560 \mathrm{~cm}^{-1}$ y $1420 \mathrm{~cm}^{-1}$, respectivamente (Zawadzki y Kaczmaker, 2010). 


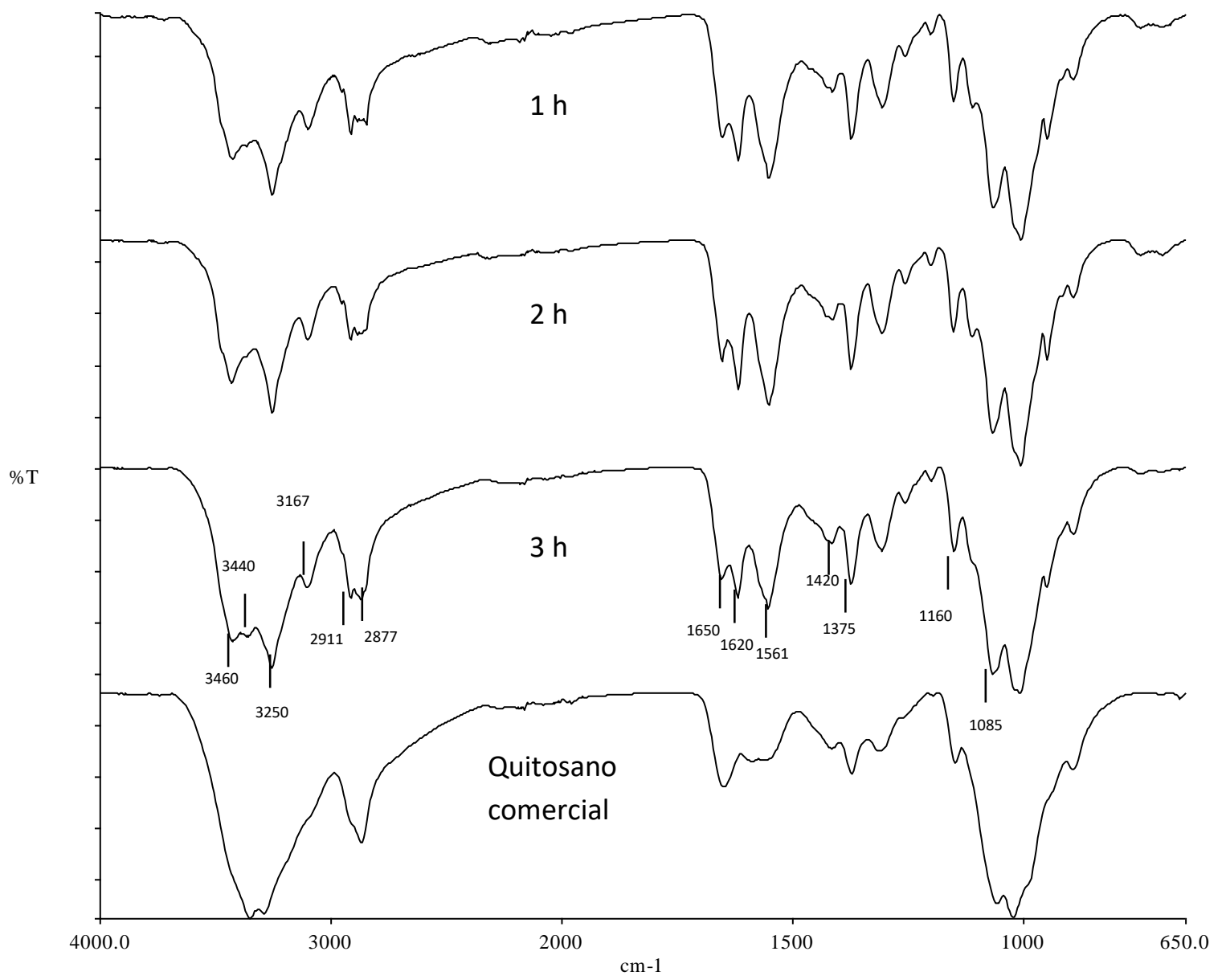

Fig. 34. Espectro infrarrojo de muestras de quitina después de 1,2 y $3 \mathrm{~h}$ de desacetilación heterogénea y su comparación con quitosano comercial.

\subsubsection{Porcentaje de solubles y PM}

El porcentaje de solubles fue calculado para cada muestra hasta las $3 \mathrm{~h}$ totales de reacción, obteniéndose $35.81 \%, 53.60 \%$ y $78.91 \%$ en orden de tiempo, siendo la muestra de $3 \mathrm{~h}$ la que presentó el mayor porcentaje de material soluble. Debido a que las muestras tomadas a 1 y $2 \mathrm{~h}$ presentaron un porcentaje menor al 53\%, se puede concluir que la fracción acetilada en la cadena es aún alta, ya que la solubilidad esta inversamente relacionada con el DA en el biopolímero. Por lo tanto, mientras mayor sea la acetilación, menos soluble será la muestra, indicando que aún se está tratando con quitina (EI 
RESULTADOS Y DISCUSIÓN

porcentaje de material soluble del biopolímero debe ser mayor al 50-60\% para ser considerado como quitosano). La muestra tardó 3 días en disolverse, necesitando tratamiento alterno de calentamiento, lo cual puede deberse al patrón de acetilación presente en la cadena, ya que se reporta que la desacetilación heterogénea puede producir patrones en bloque, indicando que la fracción acetilada no se encuentra distribuida de manera aleatoria a lo largo de la cadena, si no que se encuentra por "fragmentos" desacetilados y no desacetilados (Weinhold et al., 2009), pudiendo afectar las demás características del quitosano. Dado que la muestra a las $3 \mathrm{~h}$ presentó un porcentaje de materia soluble superior al 70\%, se realizó el análisis de $\mathrm{RMN} \mathrm{H}^{1}$ para determinar el DA, obteniéndose un 28.13\%, indicando que después de $3 \mathrm{~h}$ de desacetilación a alta temperatura puede obtenerse quitosano desacetilado al $71.87 \%$. El espectro (Figura 35) muestra el pico correspondiente al $\mathrm{H}$ del grupo acetilo a $2.1 \mathrm{ppm}$ y las señales correspondientes a los H de C2-C6 aparecen entre 3.4-4 ppm. El H del C1 se encuentra en 4.9 ppm.

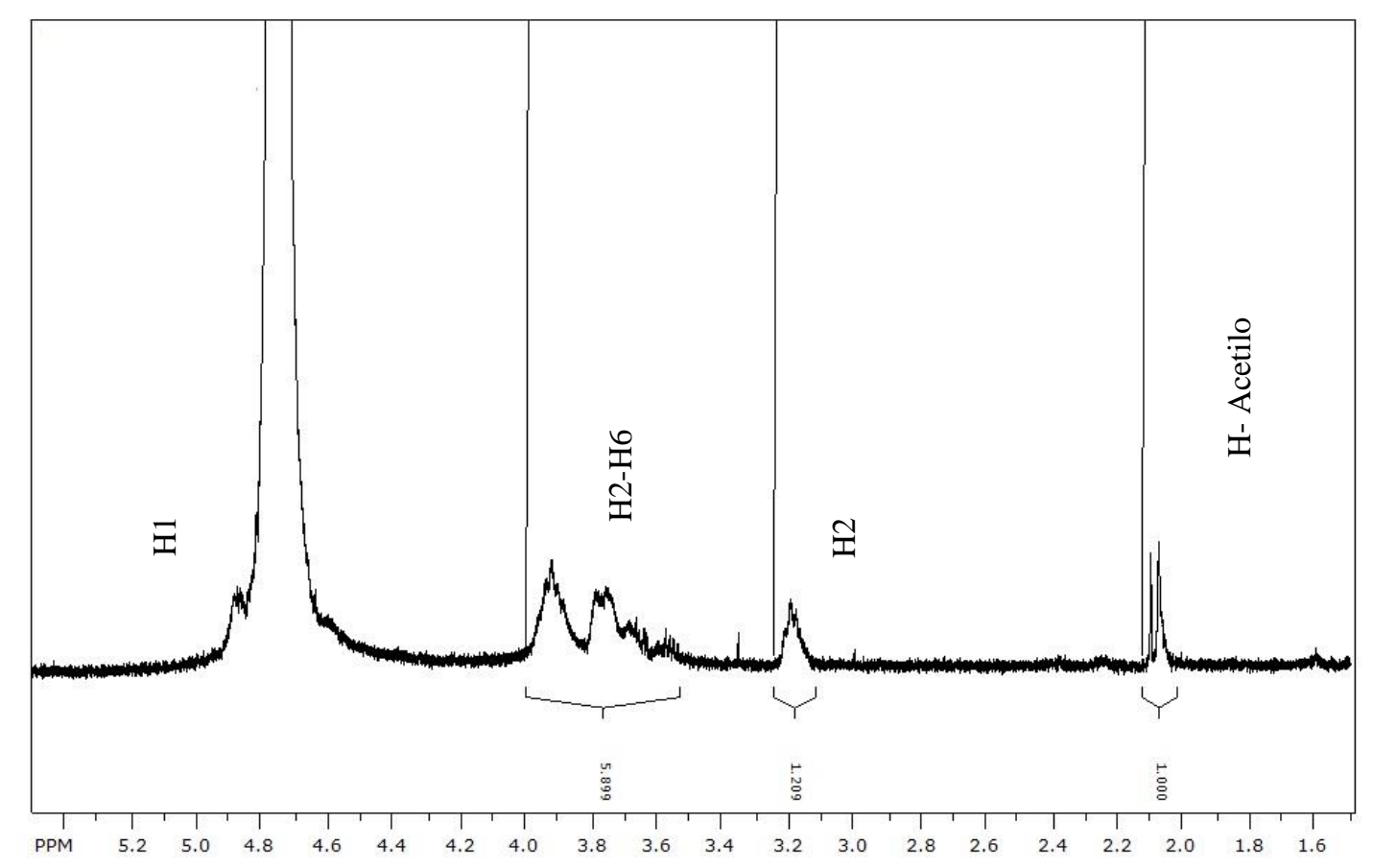

Fig. 35. Espectro de $\mathrm{RMN} \mathrm{H}^{1}$ realizado en $\mathrm{DCl}+\mathrm{D}_{2} \mathrm{O}$ a $25^{\circ} \mathrm{C}(500 \mathrm{MHz})$ de muestra de quitosano después de $3 \mathrm{~h}$ de desacetilación 


\section{RESULTADOS Y DISCUSIÓN}

El DA determinado es similar (28.13\%) al porcentaje reportado por Sigma-Aldrich para su quitosano de peso molecular medio, el cual puede variar entre 15 y 25\% (catálogo SigmaAldrich); por lo que esto también evidencia la correcta desacetilación de la quitina a quitosano.

EI PM fue determinado con base en el porcentaje de materia soluble, obteniéndose 325 KDa y una viscosidad intrínseca [n] de $668 \mathrm{~mL} / \mathrm{g}$. El valor de PM del quitosano obtenido por desacetilación de quitina extraída biológicamente se encuentra dentro del rango de quitosano de alto peso molecular reportado por Sigma-Aldrich (310-375 KDa), por lo que el uso de quitina con PM mayor es adecuado para obtener quitosano con PM igualmente alto. Esto se debe a que es necesario aumentar el tiempo de reacción y/o temperatura del álcali para aumentar la desacetilación, lo que comúnmente resulta en pérdida del PM (Pacheco et al., 2011). En este trabajo, el alto PM de la quitina utilizada para la desacetilación contribuye a mantenerlo aún con el tratamiento a altas temperaturas y largo periodo de tiempo.

\subsubsection{Cristalinidad mediante difracción de Rayos-X}

La cristalinidad relativa del quitosano resultó en $87.70 \%$, solamente $3 \%$ menor que la cristalinidad de la quitina proveniente del escalamiento, por lo que el tratamiento de 3 horas con $\mathrm{NaOH}$ al $50 \%$ y la temperatura alta no disminuyeron la cristalinidad. El patrón de difracción (Figura 36) muestra que no hubo pérdida de picos cristalinos, siendo similar al patrón de la quitina. Este resultado puede indicar el motivo por el que la muestra de quitosano con $3 \mathrm{~h}$ de desacetilación tardó tres días en disolverse, ya que a mayor cristalinidad menor será la solubilidad (loelovich, 2014). Sin embargo, un quitosano con alto $I_{C R}$ puede utilizarse para elaborar películas con mejores propiedades mecánicas, como modulo elástico y fuerza de tensión mayores (Yuan et al., 2011) 
RESULTADOS Y DISCUSIÓN

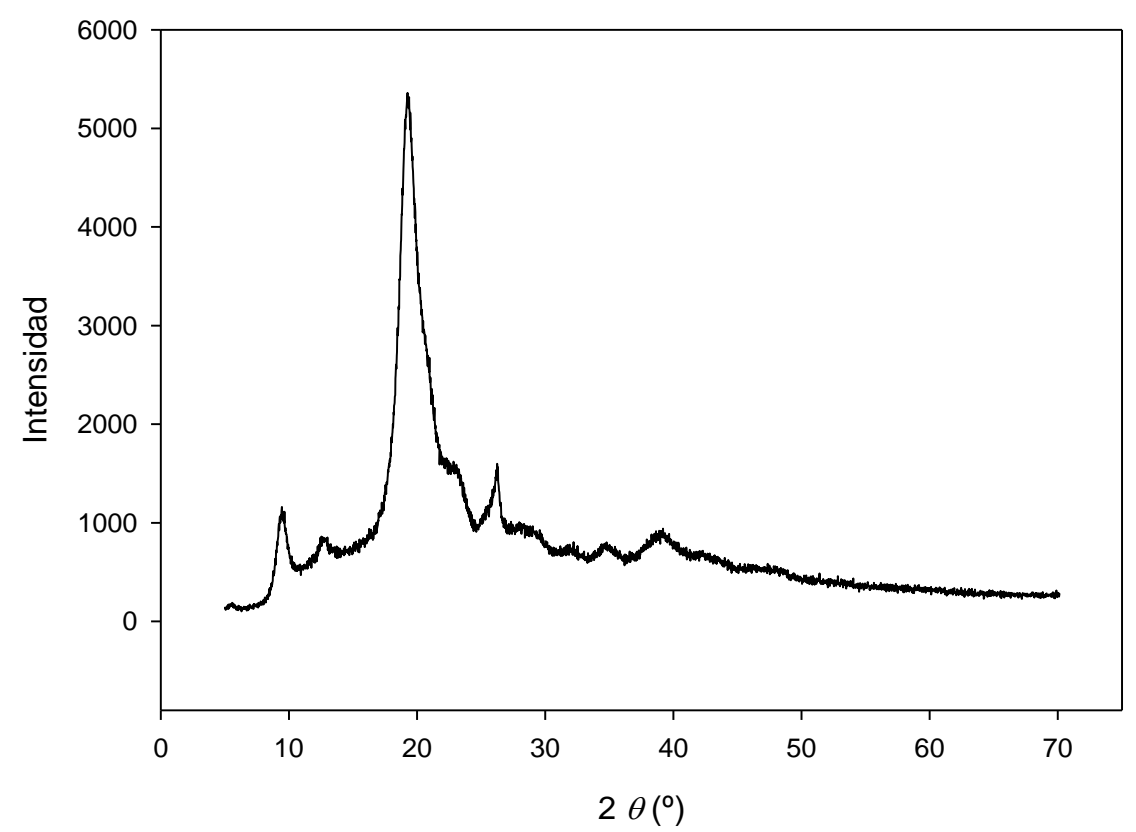

Fig. 36. Patrón de difracción de rayos $x$ a $\lambda=1.5418$ A en $2 \theta=4.5-70^{\circ} \mathrm{C}$ cada $0.02^{\circ}$ de quitosano después de $3 \mathrm{~h}$ de desacetilación.

La cristalinidad del quitosano puede variar desde $48 \%$ hasta $89 \%$, dependiendo del organismo del que se obtenga la quitina o el quitosano de manera directa. El I $\mathrm{CR}$ obtenido en este trabajo correspondería a quitosano de cristalinidad alta (Kaya et al., 2014).

\subsubsection{Conclusiones parciales sobre obtención de quitosano mediante desacetilación} heterógenea de quitina La utilización de quitina de alto PM obtenida mediante inoculación sucesiva sobre DC de L y R para la obtención de quitosano mediante desacetilación heterógenea es un método que resulta en quitosano de igualmente alto PM, además de mantener la cristalinidad relativa alta, a pesar del tratamiento a altas temperaturas y con álcali concentrado. Este método de obtención puede generar ventajas en las posibles aplicaciones del quitosano, como son la liberación controlada de medicamentos, la encapsulación de proteínas (Kumar, 2000; Honary et al., 2009) o mejorar la actividad antimicrobiana contra bacterias gram-positivas como Staphylococcus aureus Zheng et al., 2003). 


\section{CONCLUSIONES GENERALES}

- La utilización de soluciones buffer en combinación con la enzima Deterzyme ${ }^{\circledR}$ son una buena opción para desproteinizar el desperdicio de camarón, ya que eliminan el $80 \%$ de proteína aproximadamente, sin necesidad del uso de álcalis; sin embargo, es recomendable aumentar el uso de ácido o realizar la desmineralización como paso inicial para incrementar la remoción de minerales.

- La inoculación sucesiva de 5\% de inóculo de Lactobacillus brevis y una concentración de Rhizopus oligosporus de $10^{9}$ esporas/g de desperdicio de camarón es una alternativa para obtener quitina y compuestos de valor agregado como hidrolizados protéicos, enzimas y pigmentos con alta actividad antioxidante.

- El proceso de cultivo L/R $10^{7}$ para extracción biológica de quitina puede ser utilizado sobre cantidades mayores de DC para mejorar el rendimiento de obtención de quitina, así como compuestos de valor agregado.

- La quitina obtenida mediante cultivo L/R $10^{7}$ puede además utilizarse para la obtención de nanofibrillas, siendo posible su utilización para la elaboración de películas con módulo elástico mayor al presentado por películas de nanofibrillas de quitina extraída químicamente, resultado relacionado con la decoloración la quitina en hojuela con hipoclorito de sodio previo a la obtención de nanofibrillas y el sonicado de las suspensiones de nanofibrillas con las que se elaboran las películas.

- La quitina obtenida mediante el método de inoculación sucesiva L/R $10^{7}$, al presentar alto peso molecular y cristalinidad, puede ser desacetilada heterogéneamente a quitosano, resultando en un biopolímero semicristalino con alto peso molecular. 


\section{TRABAJOS PRESENTADOS Y PUBLICACIONES}

\subsection{Trabajos presentados}

* Póster: "Protein removal from shrimp wastes by successive inoculation of Lactobacillus brevis and Rhizopus oligosporus". Simposio Iberoamericano de Quitina (2015).

* Póster: "Chitin extraction by biological methods". International Conference on Fiber and Polymer Biotechnology (2016).

\subsection{Estancias}

* Estancia de investigación en la Universidad de Tottori, Prefectura Tottori, Japón; de Septiembre (2016) a Febrero (2017). Tratamiento mecánico de quitina extraída biológicamente para la obtención de nanofibrillas de quitina.

\subsection{Publicaciones}

*Aranday-García, R., Román, G.A., Shirai, K., Ifuku, S. (2017). Successive inoculation of Lactobacillus brevis and Rhizopus oligosporus on shrimp wastes for recovery of chitin and added-value products. Process biochemistry. 58:17-24.

*Aranday-García, R. et al., (2018) Chitin biological extraction from shrimp wastes by microorganisms inoculation and its fibrillation for elastic nanofibers sheets preparation. Sometido.

*Aranday-García, R., R. et al., (2018) Heterogeneous deacetylation of chitin extracted by successive inoculation of Lactobacillus brevis and Rhizopus oligosporus for high crystallinity and molecular weight chitosan obtaining. En preparación. 

shrimp wastes for recovery of chitin and added-value products

Rut Aranday-García ${ }^{\mathrm{a}}$, Angélica Román Guerrero ${ }^{\mathrm{a}}$, Shinsuke Ifuku ${ }^{\mathrm{b}}$, Keiko Shirai ${ }^{\mathrm{a}, *}$

${ }^{a}$ Universidad Autonoma Metropolitana-Iztapalapa, Biotechnology Department, Laboratory of Biopolymers and Pilot Plant of Bioprocessing of Agro-Industrial and Food ByProducts, Av. San Rafael Atlixco, No. 186, 09340, Mexico City, Mexico

b Graduate School of Engineering, Department of Chemistry and Biotechnology, Tottori University, Koyamacho-minami 4-101, Tottori city, Tottori Prefecture, 680-8550, Japan

\section{A R T I C L E I N F O}

\section{Keywords:}

Lactobacillus brevis

Rhizopus oligosponus

Protein hydrolysates

Astaxanthin

Radical scavenging activity

\begin{abstract}
A B S T R A C T
The deproteinization is a major constraint for chitin recovery from crustacean wastes. In this work, high protein removal was achieved through the combination of two-stage solid state culture by Lactobacillus brevis and Rhizopus oligosporus. The first stage was carried out employing a heterofermentative starter (L. brevis) using glucose as sole carbon source. For the second stage, the inoculum levels of the food grade fungi were $10^{3}, 10^{5}$ or $10^{7}$ spores $/ \mathrm{ml}$. The highest deproteinization $(96 \% \pm 0.43 \%)$ and demineralization $(66.45 \pm 2.14 \%)$ were achieved with $10^{7}$ spores $/ \mathrm{ml}$. The protein removal was attributed to acid and neutral proteolytic activities, which highest activity during culture was determined at $\mathrm{pH}$. Lactic acid was the main organic acid produced along with acetic, succinic and oxalic acids. The released protein hydrolysates (120.56 mg protein $/ \mathrm{g}$ ) displayed $M_{W}$ range between $25 \times 10^{3}$ and $11 \times 10^{3} \mathrm{Da}$. The highest concentration of astaxanthin extracted from liquid was $8.78 \mu \mathrm{g} / \mathrm{g}$. Protein hydrolysates and astaxanthin showed radical scavenging activity with $\mathrm{I}_{\mathrm{C5} 0}$ of $1.13 \pm 0.03 \mathrm{mg} / \mathrm{g}$ and $2.02 \pm 0.01 \mu \mathrm{g} / \mathrm{g}$, respectively. The purified chitin presented molecular weight of $1313 \times 10^{3} \mathrm{Da}$, preserving high crystalline index $\left(\mathrm{I}_{\mathrm{CR}}\right.$ of $\left.87.5 \%\right)$ and $93.67 \%$ degree of acetylation.
\end{abstract}

1. Introduction

Chitin $(\mathrm{CH})$, poly $(\mathrm{B}(1 \rightarrow 4))$-2-acetamido-2-deoxy-D-glucan, and its deacetylat ed derivative, chitosan, found applications in drug delivery, water treatment, tissue engineering, textiles or in cosmetics, among others [1]. Lactic acid fermentations (LAF) proved successful for $\mathrm{CH}$ recovery, as well as protein hydrolysates and pigments from crustacean wastes. The $\mathrm{pH}$ and acid production have been clearly established as crucial factors in LAF for inhibition of pathogen, spoilage microorganisms and demineralization (DM) of these wastes [2-6]. DM of shrimp (Litopenaeus vannamei) wastes (SW) is attained by solubilization of minerals by the produced organic acid from lactobacilli, whereas deproteinization (DP) is ascribed to digestive and microbial proteases produced during fermentation. According to Pacheco et al. [4] maximum protein removal was determined at the optimum lactic acid bacteria (LAB) growth, which evidenced the key role of LAB proteases for chitin extraction during LAF of SW employing the homofermentative Lactobacillus plantarum as the starter. The contribution of the lactobacilli to the proteolysis has been extensively studied in milk products, which is initiated by the cell envelope proteinase that releases peptides which in turn are degraded by peptidases [7]. The role of proteolytic enzymes from LAB was corroborated by Flores-Albino et al. [6] in a Lactobacillus plantarum fermentation of sterile medium based on crab wastes and molasses for simultaneous chitin and lactic acid production. Therein, the proteolytic activity was more efficient at neutral $\mathrm{pH}$ where the highest DP was achieved.

In another related work, the presence of active digestive enzymes in shrimp hepatopancreas exerted a clear contribution in DP when SW was fermented at low temperature $\left(15^{\circ} \mathrm{C}\right)$ far from the optimum temperature for LAB growth [4]. Noteworthy, most of the digestive proteolytic enzymes are active at neutral and alkaline $\mathrm{pH}$; they have been identified as trypsin, cathepsin, collagenase chymotrypsin, elastase, and carboxypeptidases [8-10]. The contribution of these endogenous proteases is well established because the highest DP was determined during the initial $24 \mathrm{~h}$ when $\mathrm{pH}$ of fermentation varied from 7 to 6 [4]. In spite of digestive acid, proteases have been also reported [8], the digestive enzyme composition might vary with the diet, body size and farm conditions and low pH is a constraint for DP of SW. This work is first to study, to the best of our knowledge, the use of successive inoculation of Lactobacillus brevis and the GRAS fungi Rhizopus oligos-

\footnotetext{
- Corresponding author.

E-mail addresses: ruthy_1986@yahoo.com (R. Aranday-García), arogue@xanum.uam.mx (A. Román Guerrero), sifuku@chem.tottori-u.ac.jp (S. Ifuku), smk@xanum. uam.mx (K. Shirai)

http://dx, doi.org/10.1016/j.procbio. 2017.04.036

Received 9 January 2017; Received in revised form 24 April 2017; Accepted 25 April 2017

Available online 29 April 2017

1359-5113/ @ 2017 Elsevier Ltd. All rights reserved.
} 


\section{TRABAJOS PRESENTADOS, PUBLICACIONES Y ESTANCIAS}

porus to produce acid proteases for total DP of SW for CH recovery and other added value products. This work also demonstrates that the heterolactic Lactobacillus brevis offers the advantage of the production of wide variety of chemical compounds such as lactic acid, ethanol, acetic acid, and $\mathrm{CO}_{2}$ as products of glucose fermentation [11].

2. Materials and methods

2.1. Materials

\subsubsection{Shrimp wastes and chitin}

SW was obtained from Mexico City's central seafood market and consisted of head and thorax. Waste was minced through a $0.3 \mathrm{~cm}$ sieve using a meat mincer (Torrey Mexico) and stored at $-20{ }^{\circ} \mathrm{C}$. Chitin and 2, 2-diphenyl-1-picrylhydrazyl (DPPH) were purchased to SigmaAldrich (USA).

\subsubsection{Microorganisms and inoculum preparation}

Lactobacillus brevis (isolated from SW) was maintained in Man Rogosa Sharpe (MRS) agar at $8{ }^{\circ} \mathrm{C}$. The inoculum was prepared by deposition from the bacterial slants in MRS broth incubated at $30{ }^{\circ} \mathrm{C}$ for $24 \mathrm{~h}$. Later on, $1 \mathrm{ml}$ of MRS broth was employed for inoculation of $100 \mathrm{ml}$ and incubated at $30^{\circ} \mathrm{C}$ up to a count of $10^{9}$ colony forming units (CFU) per $\mathrm{ml}$.

Rhizopus oligosporus was cultured on potato dextrose agar (PDA) slants and kept $8{ }^{\circ} \mathrm{C}$ until needed. The spore suspension was obtained by mechanical agitation with a solution of $0.1 \%(\mathrm{v} / \mathrm{v})$ of tween 80 up to a conidia count of $10^{9}$ spores $/ \mathrm{ml}$.

\subsection{Lactic acid fermentation of shrimp wastes}

Solid state cultures (SSC), in which the substrate bed was left static, unmixed and without force aeration were carried out in two stages: (i) Flask level in a Koji style system and (ii) Laboratory-scale reactor level. The first stage allowed fungal inoculum size determination and the second, the standardization of the procedures of organic acids production, protein, mineral removal from the SW and the downstream processing.

\subsubsection{Koji style solid state cultures}

SSC for small scale was conducted with a mixture of $100 \mathrm{~g}$ of minced SW (Litopenaeus sp), glucose 10\% (wt/wt) and 5\% (v/wt) of Lactobacillus brevis inoculum incubated at $30^{\circ} \mathrm{C}$ for $120 \mathrm{~h}$, followed by addition of $10 \%$ (wt/wt) of glucose and inoculated with spore suspension of Rhizopus oligosporus and then, incubated for additional $72 \mathrm{~h}$. Fungal inoculum level was varied $10^{3}, 10^{5}$ and $10^{7}$ spores/g SW. Samples were taken every $24 \mathrm{~h}$ and filtered $(177 \mu \mathrm{m})$ in darkness. Filtrates were stored at $-20{ }^{\circ} \mathrm{C}$ and solids were dried at $40{ }^{\circ} \mathrm{C}$ during $24 \mathrm{~h}$ for subsequent analyses.

\subsubsection{Laboratory-scale reactor}

The selected fungal inoculum level from the flask fermentation was employed in the column reactor. In a typical procedure, a mixture consisting of SW, $10 \%(\mathrm{wt} / \mathrm{wt})$ glucose and $5 \%(\mathrm{v} / \mathrm{wt})$ of $L$ brevis was placed in a stainless steel column reactor, as reported elsewhere $[4,5]$. The column reactor had $10 \mathrm{~kg}$ of nominal capacity and it was filled up to $8 \mathrm{~kg}$ of the mixture as working capacity. Reactor dimensions were $42 \mathrm{~cm}$ length and $20 \mathrm{~cm}$ in internal diameter. Reactor contents were incubated up to $192 \mathrm{~h}$ at $30^{\circ} \mathrm{C}$. Sample aliquots were withdrawn every $24 \mathrm{~h}$ for further analyses.

\subsection{Analyses of samples}

2.3.1. Determination of $\mathrm{pH}$, organic acids, gucose, and astaxanthin

The $\mathrm{pH}$ of samples was measured using a potentiometer $(\mathrm{pH} 210$ HANNA, Italy). Liquid samples were diluted (1:10 wt/v) and total titratable acidity (TTA) was determined by potentiometric titration with $0.1 \mathrm{~N} \mathrm{NaOH}$ to a final $\mathrm{pH} 8$ and expressed as mmol of lactic acid per gram [2]. Liquid samples from fermentation were diluted (1:10) twice and centrifuged at $10,000 \mathrm{rpm}$ for $20 \mathrm{~min}$ in the first dilution for glucose and organic acids determination by HPLC. Concentrations of lactic, oxalic, acetic, succinic, acids, as well as glucose, were determined with an HPLC system Agilent 1260 infinity equipped with an autosampler/injector, Refractive Index (RI) as a detector. A column Aminex HPX-87H $300 \mathrm{~mm} \times 7.8 \mathrm{~mm}$ was used with a mobile phase of $5 \mathrm{mM} \mathrm{H}_{2} \mathrm{SO}_{4}$ with a flow of $0.6 \mathrm{ml} / \mathrm{min}$ at $40^{\circ} \mathrm{C}$.

Astaxanthin (Ast) was extracted from liquid samples from fermentation by means of dilution 1:10 (wt/v) in acetone for $1 \mathrm{~h}$ with agitation and centrifuged at $10,000 \mathrm{rpm}$ for $10 \mathrm{~min}$. All samples were maintained at the darkness until analysis. Ast was measured at a wavelength of $470 \mathrm{~nm}$ with a column Agilent Eclipse XD 18 (C18) with a mixture of methanol/acetonitrile/ethyl acetate/water (80:10:5:5), with a flow of $1 \mathrm{ml} / \mathrm{min}$ at $25^{\circ} \mathrm{C}$.

Samples for Ast determination were diluted 1:10 (wt/v) in acetone and centrifuged at $10,000 \mathrm{rpm}$ for $10 \mathrm{~min}$. Later on, $1 \mathrm{ml}$ of diluted supernatant was filtered through $45 \mathrm{~mm}$ membrane before injection. The peak identities of organic acids and trans-astaxanthin were confirmed by their retention times and characteristic spectra of standard chromatograms. They were quantified from their peak areas in relation to the organic acids and trans-astaxanthin reference standard (Sigma-Aldrich USA) [12].

\subsubsection{Chemical composition analysis}

Moisture and ash from solids and $\mathrm{CH}$ were determined using standard methods [13]. Total nitrogen contents were measured by Kjeldahl in automated equipment (Büchi, Switzerland). Corrected protein contents were calculated by the subtraction of the chitin nitrogen from the total nitrogen content and multiplied by 6.25. DM and DP Percentages were obtained using Eq. (1).

$\mathrm{Y}(\%)=\frac{\left[\left(\mathrm{X}_{0} \times \mathrm{S}_{0}\right)-\left(\mathrm{X}_{\mathrm{R}} \times \mathrm{S}_{\mathrm{R}}\right)\right]}{\left(\mathrm{X}_{0} \times \mathrm{S}_{0}\right)} \times 100$

where $\mathrm{Y}$ is $\mathrm{DP} \%$ or $\mathrm{DM} \%$ and $\mathrm{X}_{0}$ and $\mathrm{X}_{\mathrm{R}}$ are the protein or ash content percentages in raw and fermented samples, respectively. $S_{0}$ and $S_{R}$ are raw and fermented samples weights $(\mathrm{g})$, respectively [5]. Protein hydrolysate concentrations were determined as the soluble protein in the liquid fractions by Lowry-Peterson [14].

\subsubsection{Physicochemical characterization}

Solid fraction from SSC was treated with $\mathrm{HCl} 0.4 \mathrm{~N}(1: 15 \mathrm{wt} / \mathrm{v})$ for $1 \mathrm{~h}$ to remove minerals and the obtained pure $\mathrm{CH}$ was fully characterized. Viscosimetric average molecular weight $\left(M_{v}\right)$ was conducted in an Oswald viscosimeter using $N, N$-dimethylacetamide containing lithium chloride ( $5 \%$ wt/v) and calculated using Mark Houwink Kuhn Sakurada (Eq. (2)).

$[\eta]=K M_{W}{ }^{a}$

where $\alpha=0.69$ and $K=2.4 \times 10^{-4} 1 / \mathrm{g}$.

The degree of acetylation (DA) was obtained using proton nuclear magnetic resonance ( ${ }^{1} \mathrm{H}$ NMR) spectroscopy in Bruker AVANCE-III 500 (Germany) spectrometer at $200 \mathrm{MHz}$ in $\mathrm{DCl} / \mathrm{D}_{2} \mathrm{O}$ with 3-(trimethylsilyl) propionic acid as the intemal reference. DA was calculated by integration of assigned signals on the NMR spectra. $\mathrm{I}_{\mathrm{CR}}$ was determined by Xray diffraction measurements in a diffractometer (Bruker D8 Advance) with an incident radiation $\mathrm{Cu} \mathrm{K \alpha}$ and wavelength of $\lambda=1.5418 \AA$ in the range of $2 \theta=4.5$ to $70^{\circ} \mathrm{C}$ with steps of $0.02^{\circ}$ according to Eq. (3) $[5,15]$.

$I_{C R}=\frac{I_{110}-I_{a m}}{I_{110}} \times 100$

Where $I_{110}$ is the intensity of (110) peak at around $2 \theta=20^{\circ}$ corresponding to the maximal intensity and $I_{a m}$ is that at $2 \theta=16^{\circ}$ 


\section{TRABAJOS PRESENTADOS, PUBLICACIONES Y ESTANCIAS}

corresponding mainly to the amorphous contribution.

The values of apparent crystallite diameter $\left(D_{a p}\right)$ were determined by the Scherrer Eq. (4).

$D_{a p[110]}=\frac{K \lambda}{\beta_{0} \cos \theta}$

where $\mathrm{K}$ is a constant close to $0.9, \lambda(\AA)$ is the wavelength of the incident radiation, $\beta_{0}$ (rad) is the width of the crystalline peak at half height and $2 \theta(\mathrm{rad})$ is the scattering angle of the [110] diffraction line.

ATR-FTIR spectra were acquired on a Perkin Elmer 100 (UK) ATRFTIR spectrometer at $24^{\circ} \mathrm{C}$ and $30 \%$ relative humidity (RH). Samples were dried for $72 \mathrm{~h}$ at $45^{\circ} \mathrm{C}$ prior to analyses and spectra were collected by averaging 64 scans between $4000-650 \mathrm{~cm}^{-1}$ spectral range and $4 \mathrm{~cm}^{-1}$ resolution.

\subsubsection{Bacterial and fungal growth}

Microbial growth was determined by colony enumeration inoculating decimal dilutions of samples in $0.9 \%$ (wt/v) of sterile $\mathrm{NaCl}$ solution in standard methods agar (SMA) for aerobic mesophilic microorganisms, MRS agar for lactic acid bacteria, eosin methylene blue (EMB) agar for coliforms and PDA acidified with tartaric acid (1\% v/wt $\mathrm{pH}$ 3.5) for yeast and fungi. The results were expressed as Log of CFU $/ \mathrm{ml}$.

\subsubsection{Proteolytic activity assays and zymograms}

Samples were diluted $1: 10(\mathrm{wt} / \mathrm{v})$ and centrifuged at $10,000 \mathrm{~g}$ and $4{ }^{\circ} \mathrm{C}$ for $25 \mathrm{~min}$ and supernatants were treated as the crude enzyme. Neutral protease activity was measured using $1 \%$ casein as substrate (phosphate buffer $\mathrm{pH} 750 \mathrm{mM}$ ) and acidic protease activity was determined with $2 \%$ hemoglobin (universal buffer $\mathrm{pH} 50.05 \mathrm{M}$ ). $75 \mu \mathrm{l}$ of crude enzyme was mixed with $500 \mu \mathrm{l}$ of buffer and incubated for $1 \mathrm{~h}$ at $30{ }^{\circ} \mathrm{C} .1 \mathrm{ml}$ of trichloroacetic acid $(5 \% \mathrm{wt} / \mathrm{v})$ was added to halt the reaction. The sample was centrifuged at room temperature for $10 \mathrm{~min}$ at $10,000 \mathrm{rpm}$ to remove the precipitate. For control experiments, trichloroacetic acid was added right after crude enzyme addition without incubation. Absorbance was measured at $280 \mathrm{~nm}$. One unit of total neutral or acidic protease activity was expressed as the amount of enzyme required to hydrolyze casein or hemoglobin producing 0.001 changes in absorbance per ml per min [16,17]. The presence of protease activity was detected in zymograms employing casein and hemoglobin substrates for neutral and acid proteolytic activities, respectively [18].

\subsubsection{Tricine SDS-PAGE}

The sample was suspended in $5 \mathrm{ml}$ of acetic acid solution $(0.087 \mathrm{M})$ prior to injection in a Sep-Pak C-18 ${ }^{*}$ cartridge (Waters, USA) eluted with $5 \mathrm{ml}$ acetonitrile solution (50\%). Eluted samples were freeze dried. Then, tricine SDS-PAGE was conducted using the molecular mass marker (Precision Plus Protein Unstained Standard, Bio-Rad) as protein standards [19]. Electrophoresis gels were stained with coomassie blue (Bio-Rad, USA) and analyzed with the ImageJ 1.41o software (National Institutes of Health, USA).

2.3.7. Determination of radical scavenging activity (RSA) by DPPH

RSA in liquid samples was determined using $2 \mathrm{ml}$ of freshly prepared DPPH solution in methanol $0.1 \mathrm{mM}$, which was added to protein hydrolysates samples or Ast in concentration ranges of $0.5-2 \mathrm{mg}$ protein $/ \mathrm{g}$ or $0.5-5 \mathrm{mg} \mathrm{Ast} / \mathrm{g}$, respectively. Test tubes were incubated at the darkness for $30 \mathrm{~min}$ at room temperature and absorbance was measured at $517 \mathrm{~nm}$ with a UV-vis spectrophotometer (Genesys 6, ThermoSpectronic). Distilled water was used as the control for protein samples and acetone for Ast. RSA (\%) was calculated according to Eq. (5).

$R S A=\left[\frac{\left(A_{0}-A_{x}\right)}{A_{0}}\right] \times 100$

where RSA is the radical scavenging activity (\%), $A_{0}$ and $A_{x}$ are the absorbance at $517 \mathrm{~nm}$ of control and samples, respectively.

RSA determinations were carried out in triplicate. Experimental data were fitted to Probit statistical analysis in $\mathrm{NCSS}^{\circ}$ program (NCSS LCC USA). The $\mathrm{IC}_{50}$ value was the concentration of protein or Ast that inhibit $50 \%$ of DPPH radical scavenging activity [20].

\subsubsection{Field emission scanning electron microscopy (FE-SEM)}

$\mathrm{CH}$ flake was dried at $120^{\circ} \mathrm{C}$ for $3 \mathrm{~h}$ prior to analysis. The sample was coated with an approximately $2 \mathrm{~nm}$ layer of osmium by an osmium coater (NEOC-STB Meiwafosis) and observed by FE-SEM (JSM-6700F; JEOL, Ltd.) operating at $2,0 \mathrm{kV}$.

\subsection{Statistical analyses}

Experimental data were subjected to analysis of variance and multiple comparisons of means by Tukey-Kramer test in order to determine significant differences among treatments ( $\mathrm{p}<0.05$ ) using the statistical program NCSS (NCSS, PASS, and GESS, 2001).

\section{Results and discussion}

3.1. Selection of suitable fungal inoculum level for fermentation of shrimp wastes

Table 1 shows the final pH, acid production, DM and DP of SW varying the inoculum level of $R$. oligosporus after LAF with $L$. brevis, as well as SSC with only added bacteria or fungi for comparison. The initial $\mathrm{pH}$ of SW decreases from 7.81 to $4.48-4.12$ during SSC, however, there were no significant differences in $\mathrm{pH}$, TTA and only at the highest fungal inoculum level DM and DP showed statistically significant different means. The DM was mainly observed during the lactic acid fermentation with lesser extent for the fungus as it can be observed with the control treatment with only $R$. oligosporus. Lactic acid can be also produced by fungi, as it has been extensively studied for Rhizopus oryzae, although under aerobic metabolism in media with high carbonnitrogen ratio [21] which might explain the low contribution of fungi to DM. The SW used in this work presented high nitrogen content, which along with the anaerobic conditions might limit the production of lactic acid. In addition, several strategies to overcome shortcomings of low mass transfer in SSC have been reported, which in turn cause low lactic acid productivity of $R$. oryzae [21].

On the other hand, the highest DP was achieved with $10^{7}$ spores/g combined with $L$. brevis. Therefore, the largest fungal inoculum was

Table 1

pH, TTA, DM and DP after $192 \mathrm{~h}$ of fermentation of shrimp wastes with several levels of fungal inoculum and with bacteria inoculation.

\begin{tabular}{|c|c|c|c|c|c|}
\hline Lactobacillus brevis (\%v/wt) & Rhizopus oligosporus inoculum (spores/g SW) & $\mathrm{pH}$ & $\begin{array}{l}\text { TTA } \\
\text { (mmol lactic acid/g SW) }\end{array}$ & $\begin{array}{l}\text { DM } \\
(\%)\end{array}$ & $\begin{array}{l}\text { DP } \\
(\%)\end{array}$ \\
\hline 5 & 0 & $4.48 \pm 0.03^{a}$ & $0.32 \pm 0.00^{\mathrm{b}}$ & $52.4 \pm 2.47^{\mathrm{a}}$ & $72.6 \pm 3.7^{\mathrm{b}}$ \\
\hline 0 & $10^{3}$ & $4.27 \pm 0.05^{b}$ & $0.10 \pm 0.03^{a}$ & $53.35 \pm 5.51^{\mathrm{a}}$ & $54.75 \pm 0.67^{\mathrm{a}}$ \\
\hline 5 & $10^{3}$ & $4.19 \pm 0.01^{c}$ & $0.33 \pm 0.02^{\mathrm{b}}$ & $52.8 \pm 0.03^{\mathrm{a}}$ & $71.8 \pm 3.19^{\mathrm{b}}$ \\
\hline 5 & $10^{5}$ & $4.13 \pm 0.01^{c}$ & $0.37 \pm 0.05^{c}$ & $53.5 \pm 1.6^{\mathrm{a}}$ & $68.0 \pm 4.1^{\mathrm{b}}$ \\
\hline 5 & $10^{7}$ & $4.12 \pm 0.01^{c}$ & $0.34 \pm 0.02^{\mathrm{b}, c}$ & $67.3 \pm 1.4^{\mathrm{b}}$ & $96.0 \pm 2.12^{c}$ \\
\hline
\end{tabular}

$\mathrm{a}, \mathrm{b}$ and $\mathrm{c}$ in a column means that groups are statistically different among inoculum level (Tukey- Kramer $\mathrm{p} \leq 0.05$ ). 


\section{TRABAJOS PRESENTADOS, PUBLICACIONES Y ESTANCIAS}
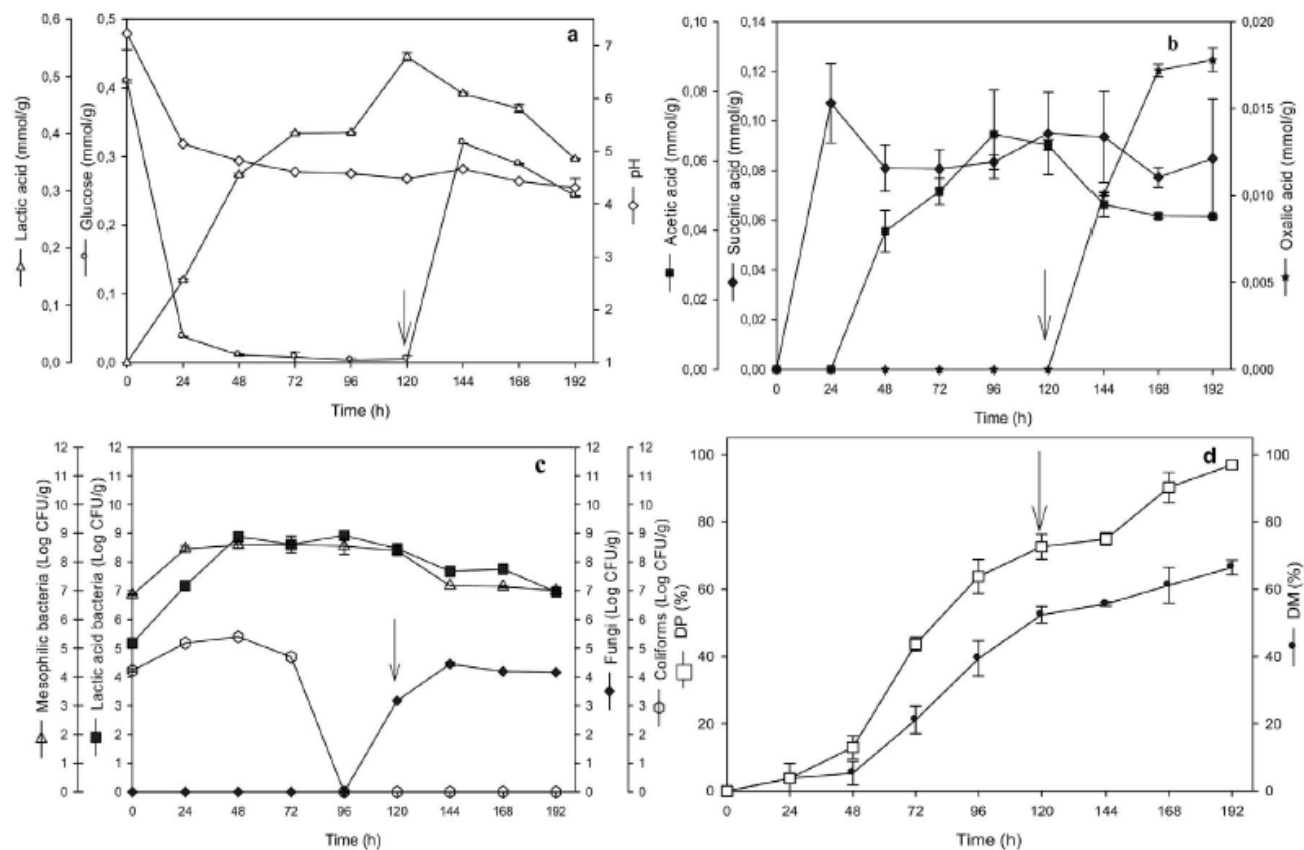

Fig. 1. Time course of SSC of SW inoculated with $5 \%$ (v/wt) of $L$ brevis and $10^{7}$ spores $/ g$ of Rhizopus oligosporus: (a) pH, glucose and lactic acid; (b) succinic acid, oxalic acid and acetic acid; (c) aerobic mesophilic microorganisms, lactic acid bacteria, coliforms and fungi counts; (d) DM and DP. The arrows indicate the addition of $10 \%$ (wt/wt) of glucose and fungal inoculation.

chosen for further experimentation.

3.2. Laboratory-scale reactor $(8 \mathrm{~kg})$ of solid state culture of shrimp wastes by $L$. brevis and $R$. oligosporus

The determined $\mathrm{pH}$, sugars, organic acids production, DM, DP and microbial growth in the $8 \mathrm{~kg}$ SSC bioreactor with $L$. brevis and the highest inoculum level of $R$. oligosporus are shown in Fig. 1. The pH presented a steep drop at $24 \mathrm{~h}$, and subsequently, a slow decrease until reaching $\mathrm{pH}$ of 4.6. There were not significantly differences from $72 \mathrm{~h}$ to $192 \mathrm{~h}$ (Fig. 1a). Lactic acid was the predominant organic acid produced and its concentration increases from $24 \mathrm{~h}$ up to $120 \mathrm{~h}$, decreasing after $144 \mathrm{~h}$ coinciding with oxalic acid production and fungi inoculation (Fig. 1b). Production of other organic acids besides lactic is explained by heterofermentative metabolism of the starter and endogenous microflora. In a related study by Özcelik et al. [22], fish based infusion broths with MRS were compared and the organic acid production varied significantly depending on lactic acid bacteria strain and media composition. Succinic acid was found from $24 \mathrm{~h}$ at relatively low concentrations of $0.11 \mathrm{mmol} / \mathrm{g}$ and remained constant whilst acetic acid was gradually increased from $48 \mathrm{~h}(0.065 \mathrm{mmol} / \mathrm{g})$ decreasing after $120 \mathrm{~h}$.

\subsection{Mineral and protein removal from shrimp wastes during solid state cultures}

DM and DP remained constant until $48 \mathrm{~h}$ but after that induction period both percentages increased (Fig. 1d). DM reached $66.45 \%$ at $192 \mathrm{~h}$ with a non-significant difference from $120 \mathrm{~h}$ to final SSC time. DP obtained at $192 \mathrm{~h}$ was $96.91 \%$, which is not significantly different to that at $168 \mathrm{~h}$. In previous reports with SW [3,23-25], the highest DM achieved in submerged culture with $30 \%$ (wt/v) varied from $83 \%$ to $97.2 \%$ when initial $\mathrm{pH}$ was adjusted to 6.5 . In the present work with SSC with $87 \%$ (wt/wt) of SW, DM values were relatively low (66.45\%), however, the yield of calcareous $\mathrm{CH}$ was significantly higher than those reported earlier and resulting chitin can be purified with low acid concentration for residual ash removal.

It is worth noting that DP percentage was higher (96\%) than that reported elsewhere $(<87 \%)[3,23-25]$, therefore, further processes are no longer required for complete protein removal.

\subsection{Bacterial and fungal growth during solid state culture}

The aerobic mesophilic microorganisms and lactic acid bacteria count increased from $24 \mathrm{~h}$ with maximal CFU at $96 \mathrm{~h}$ and subsequently decreased (Fig. 1c). The addition of glucose exerted an effect on aerobic mesophilic microorganisms at $144 \mathrm{~h}$ and also with fungal inoculation at $120 \mathrm{~h}$. Coliforms were determined on the first $24 \mathrm{~h}$, later on, they were totally inhibited. The antimicrobial effect of both lactic and acetic acid is well known, noteworthy, acetic acid is more antimicrobial than lactic acid due to its higher pKa, and therefore more non-dissociated acids can be found at a given $\mathrm{pH}$ [22]. The decrease in bacteria count coincides with fungal inoculation at $120 \mathrm{~h}$. However, fungal growth was relatively slow after inoculation at $120 \mathrm{~h}$, as shown in Fig. 1c. The relatively long lag phase observed might be due to oxygen limitations [26]. Moreover, according to the literature, the growth inhibition of the fungi Fusarium culmorum has been reported by synergistic interactions between carboxylic acids and phenolic compounds produced by $L$. brevis in barley malt substrate [27]. Contrarily, however, Feng et al. [28] reported that the growth of $R$. oligosporus in barley tempeh at the final pH of 4.9 was not significantly affected by any of the strains of Lactobacillus plantarum, Lactobacillus fermentum, Lactobacillus reuteri and Lactococcus lactis.

3.5. Determination of proteolytic activity of solid state culture of L. brevis and $R$. oligosporus

Despite the slowdown of the fungal growth, the highest DP was achieved therefore there was not significant inhibition on protease activity (Fig. 1d). Indeed, the samples of liquid fractions of SSC of SW 


\section{TRABAJOS PRESENTADOS, PUBLICACIONES Y ESTANCIAS}
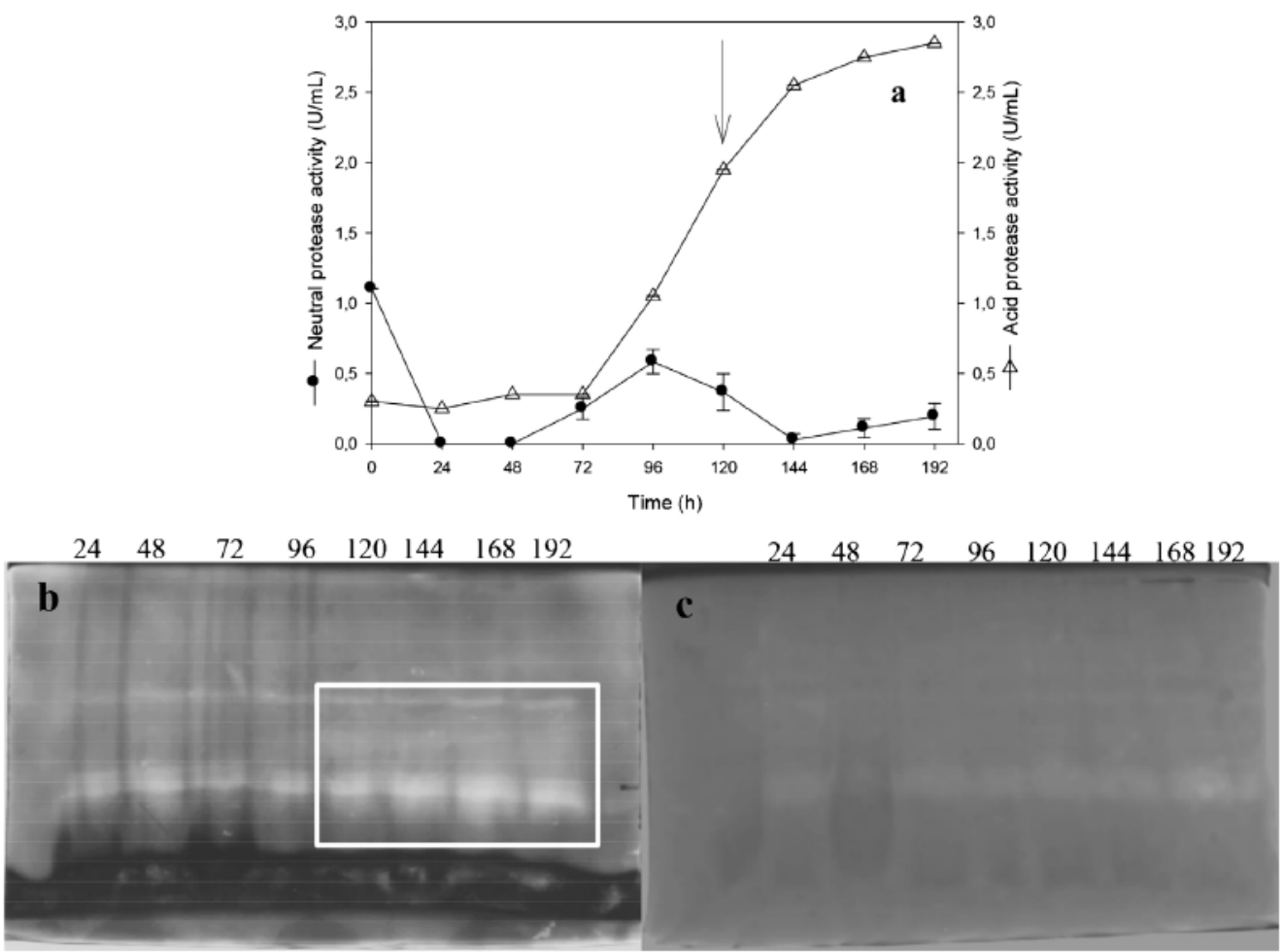

Fig. 2. Time course of proteolytic activities of samples of SSC of SW inoculated with $5 \%$ (v/wt) of $L$ brevis and $10^{7}$ spores $/ g$ of Rhizopus oligosporus (a). Zymograms of acid (b), and neutral proteolytic activities (c). The arrow indicates the addition of $10 \%(\mathrm{wt} / \mathrm{wt}$ ) of glucose and fungal inoculation. The rectangle indicates the position of acid proteases after fungal inoculation.

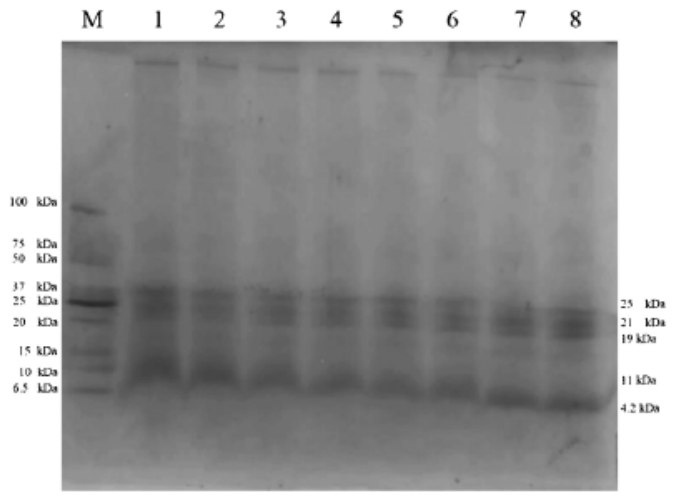

Fig. 3. Tricine SDS-PAGE profiles of protein hydrolysates produced during SW SSC of $5 \%$ (v/wt) of $L$ brevis and $10^{7}$ spores/g of Rhizopus oligosporus. Lanes: M is molecular mass marker; 1-8, protein hydrolysates for $24,48,72,96,120,144,168$ and $192 \mathrm{~h}$, respectively.

displayed proteolytic activities at pH 7 and 5 (Fig. 2a). Nevertheless, a suppression of proteolytic activity at $\mathrm{pH} 7$ was observed in the initial $48 \mathrm{~h}$, thereafter the proteolytic activity gradually increased up to a maximum of $0.58 \pm 0.09 \mathrm{U} / \mathrm{ml}$ at $96 \mathrm{~h}$ to subsequently decrease again, notwithstanding that, the fungal inoculation was carried out even with less than $0.19 \pm 0.09 \mathrm{U} / \mathrm{ml}$ remaining. This experimental evidence might be explained to the enzyme stability at $\mathrm{pH} 7$, according to Ikasari and Mitchell [29] acid proteases of R. oligosporus are stable at acidic $\mathrm{pH}$ but can be denatured at neutral conditions. On the other hand, acid proteases were produced throughout the SSC of SW with a significant increase after $120 \mathrm{~h}$, when $R$. oligosporus was inoculated. These results were corroborated by zymograms at pH 5 and 7 (Fig. 2b and c) where proteolytic activity increases after $120 \mathrm{~h}$ with additional bands. This evidences the increased proteolytic activity with $R$ oligosporus, especially at $\mathrm{pH} 5$. The $\mathrm{pH}$ decreases to 5 in the first $24 \mathrm{~h}$ and maintains around 4 until $192 \mathrm{~h}$ which might favor acid proteolytic activity from the fungi (Fig. 1c). The acid proteases produced by $R$. oligosporus are reported active between $\mathrm{pH}$ 1.5-5 with optimal activity at $\mathrm{pH} 2$ in rice bran solid state fermentation [29]. Additionally, recent studies have shown that the optimum $\mathrm{pH}$ for protease synthesis by $R$. oligosporus was $\mathbf{5}$ in SSC in a media based on sunflower meal, wheat bran and rice bran [30]. The study of the enzymatic hydrolysis of soybean protein isolate by the extracellular proteases from $R$. oligosporus carried out by Li and $\mathrm{Li}$ [31] substantiates that the protease at $\mathrm{pH}$ 5 achieves efficient degradation of soybean protein isolate. Herein, the neutral proteolytic activity increases after $144 \mathrm{~h}$ of SSC and follows the upward trend up to $192 \mathrm{~h}$ with $0.019 \pm 0.092 \mathrm{U} / \mathrm{ml}$. R. oligosporus is pointed out as acid proteases producer but also produces tripeptidyl peptidases with optimal enzyme activity at $\mathrm{pH} 7$, which is induced by protein as nitrogen source with beef extract medium $(0.2 \mathrm{U} / \mathrm{ml})$ [32].

The tricine SDS-PAGE profile of protein hydrolysates displayed bands with $\mathrm{Mw}$ higher than $50 \mathrm{kDa}$ that disappear after $48 \mathrm{~h}$ of SSC, while those with $25 \mathrm{kDa}$ were detected until $144 \mathrm{~h}$ (Fig. 3). The protein bands with Mw of $11 \mathrm{kDa}, 6.5 \mathrm{kDa}$ and $4.2 \mathrm{kDa}$ at 168 and $192 \mathrm{~h}$ of SSC, respectively, evidences the protein hydrolysis of SW by the high proteolytic activity of $R$. oligosporus thereby the release of protein hydrolysates (Fig. 2),

3.6. Quantification of radical scavenging activity of protein hydrolysates and astaxanthin produced with the solid state culture

The utilization of fish by-products for the production of bioactive peptides by lactic acid fermentation has been claimed as a profitable bioprocess [20]. The concentration of protein hydrolysates in all liquid 


\section{TRABAJOS PRESENTADOS, PUBLICACIONES Y ESTANCIAS}
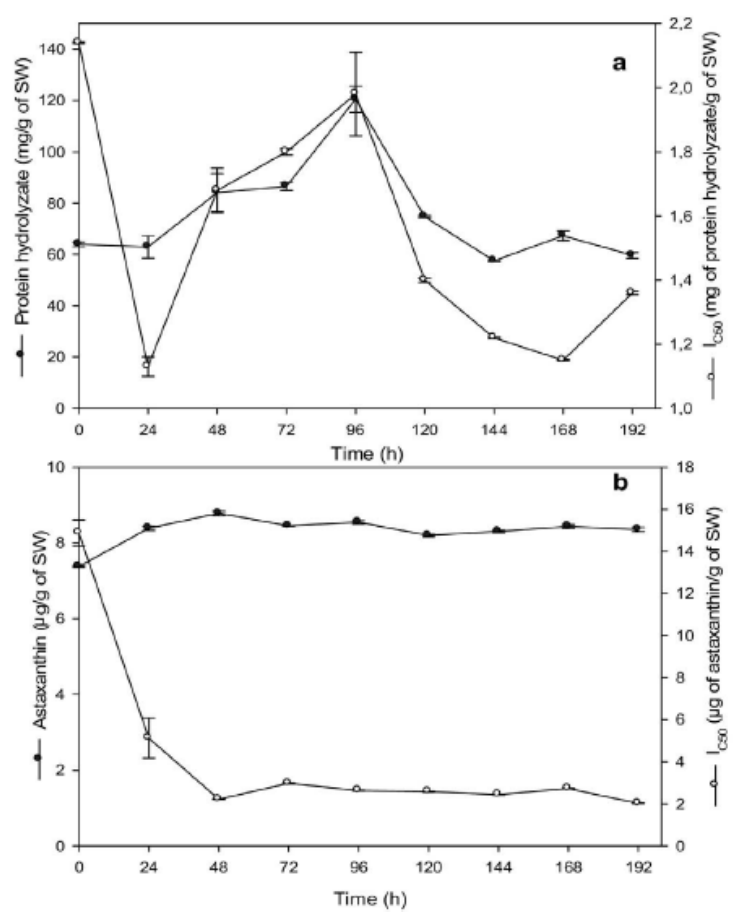

Fig. 4. Samples taken from liquid fraction of fermentation of SW inoculated with $5 \%$ (v/wt) of $L$ brevis and $10^{7}$ spores/g of Rhizopus oligosporus: Protein hydrolysate concentration and their $\mathrm{I}_{\mathrm{CSO}}(\mathrm{a})$, and Ast concentration and their $\mathrm{I}_{\mathrm{CSO}}(\mathrm{b})$.

samples in SSC was above $50 \mathrm{mg} / \mathrm{g}$ of SW with a significantly highest protein concentration at $96 \mathrm{~h}(120.57 \pm 5.17 \mathrm{mg} / \mathrm{g}$ of SW) (Fig. 4a). The lowest $\mathrm{I}_{\mathrm{C} 50}$ of protein hydrolysates was estimated at $24 \mathrm{~h}(1.13 \mathrm{mg} /$ $\mathrm{g}$ of SW) and the highest at the initial time $(2.14 \mathrm{mg} / \mathrm{g}$ of SW). The Ast concentration on liquid samples was significantly high at $48 \mathrm{~h}$, however, it was lower than the obtained in previous studies [4,12], which might be ascribed to Ast oxidation. Nevertheless, most of Ast extracted from liquid was in free or trans-isomer form, instead of trans- and cisisomers, which were detected in the solid fraction of lactic acid fermented shrimp wastes $[4,12]$. The time of fermentation seems to favor RSA because less Ast is required to reach the $\mathrm{IC}_{50}$ (Fig. 4b). Low RSA of Ast present in protein hydrolysates is due to the presence of only free or trans-isomer forms, which are less stable than cis-isomer and reacts easily with free radicals; therefore protein hydrolysates have a potential use as radical scavengers [4]. In this regard, the effectiveness of acidic proteases on enzymatic hydrolysis has been reported for tuna backbone protein, wherein pepsin achieved a high degree of protein hydrolysis (74.5\%) toward antioxidant peptide synthesis [20,33].

\subsection{Chitin characterization}

The ATR-FTIR spectra (see supplementary data for IR analysis) of $\mathrm{CH}$ obtained from SSC (purified with $\mathrm{HCl} 0.5 \mathrm{~N}$ for ash removal) and commercial $\mathrm{CH}$ showed the $\mathrm{CH}$ characteristic bands. The $\nu \mathrm{CO}$ stretching at 1085,1125 and $1160 \mathrm{~cm}^{-1}$, carbonyl stretching $(\nu \mathrm{C}=0)$ of amide I as a doublet at $1660 \mathrm{~cm}^{-1}$ and $1620 \mathrm{~cm}^{-1}$. The NH bending $(\delta \mathrm{NH})$ of the amide II at $1560 \mathrm{~cm}^{-1}$, NH stretching symmetric $(\nu \mathrm{NH})$ at $3167 \mathrm{~cm}^{-1}$ and asymmetric at $3250 \mathrm{~cm}^{-1}$. The $\mathrm{OH}(\nu \mathrm{OH})$ and $\mathrm{CH}$ $(\nu \mathrm{CH})$ stretchings were observed at 3460 and $2877 \mathrm{~cm}^{-1}$, respectively. The second $\nu \mathrm{OH}$ at $3440 \mathrm{~cm}^{-1}$ is not observed which might be due to interferences from water [34]. The $\iota \mathrm{CH}$ at $2877 \mathrm{~cm}^{-1}$ is found in a group of complex several bands, which have being identified as symmetric and asymmetric stretchings of $\mathrm{CH}$ from the ring and from
$\mathrm{CH}_{2} \mathrm{OH}$ and $\mathrm{CH}_{3}$ groups.

The $M_{w}$ of $\mathrm{CH}$ was $1313 \mathrm{kDa}$ with an intrinsic viscosity $[\eta]$ of $4000 \mathrm{ml} / \mathrm{g}$. These values are similar to previous reports of biological samples without posterior DM and DP and are higher than values reported on chemical treatments [5], where viscosity was around $3000 \mathrm{ml} / \mathrm{g}$. High $M_{w}$ shows no hydrolysis of the biopolymer, which might be ascribed to the mild purification process. The NMR analyses of $\mathrm{CH}$ show a DA of $93.67 \%$. The DA value is consistent with other reports of fermentation with lactic acid bacteria and chemical routes [5]. According to X-ray diffraction (see supplementary data for XR diffractogram of $\mathrm{CH}$ ), $\mathrm{CH}$ sample presents $\mathrm{I}_{\mathrm{CR}}$ of $97.5 \%$ and $\mathrm{D}_{\text {ap }}$ of $59.55 \%$. Diffraction pattern showed mainly 5 crystal reflections at $9.2^{\circ}, 12.7^{\circ}$, $19.1^{\circ}, 23.2^{\circ}$ and $26.1^{\circ}$, which corresponded to $020,101,040,110$, and 130 planes $[34,35]$. $\mathrm{I}_{\mathrm{CR}}$ was higher than the biologically obtained $\mathrm{CH}$ previously reported [5], where $\mathrm{I}_{\mathrm{CR}}$ was $86.4 \%$, which demonstrates that SSC with $L$. brevis and $R$. oligosporus did not affect crystallinity.

The FE-SEM Micrographs show the morphology of the fibrous $\mathrm{CH}$ network, where nanofibers are observed as thick braids with oval voids along plywood giving further evidence of protein removal, however, minerals still remain in spite of biological DM (Fig. 5)

\section{Conclusions}

The use of Lactobacillus brevis and Rhizopus oligosporus in successive inoculation on SW was an effective biological alternative for the recovery of added value compounds, such as chitin, protein, and astaxanthin. The extracted chitin presented an ash content of $10.24 \%$ and residual protein of $1.09 \%$. This calcareous chitin was chemically purified to attain an ash content of $1.01 \%$ and free of pigments. The study shows the feasibility to utilize $R$. oligosporus, a GRAS microorganism for in situ production of acid proteases that work efficiently on the chitin-protein network. 


\section{TRABAJOS PRESENTADOS, PUBLICACIONES Y ESTANCIAS}

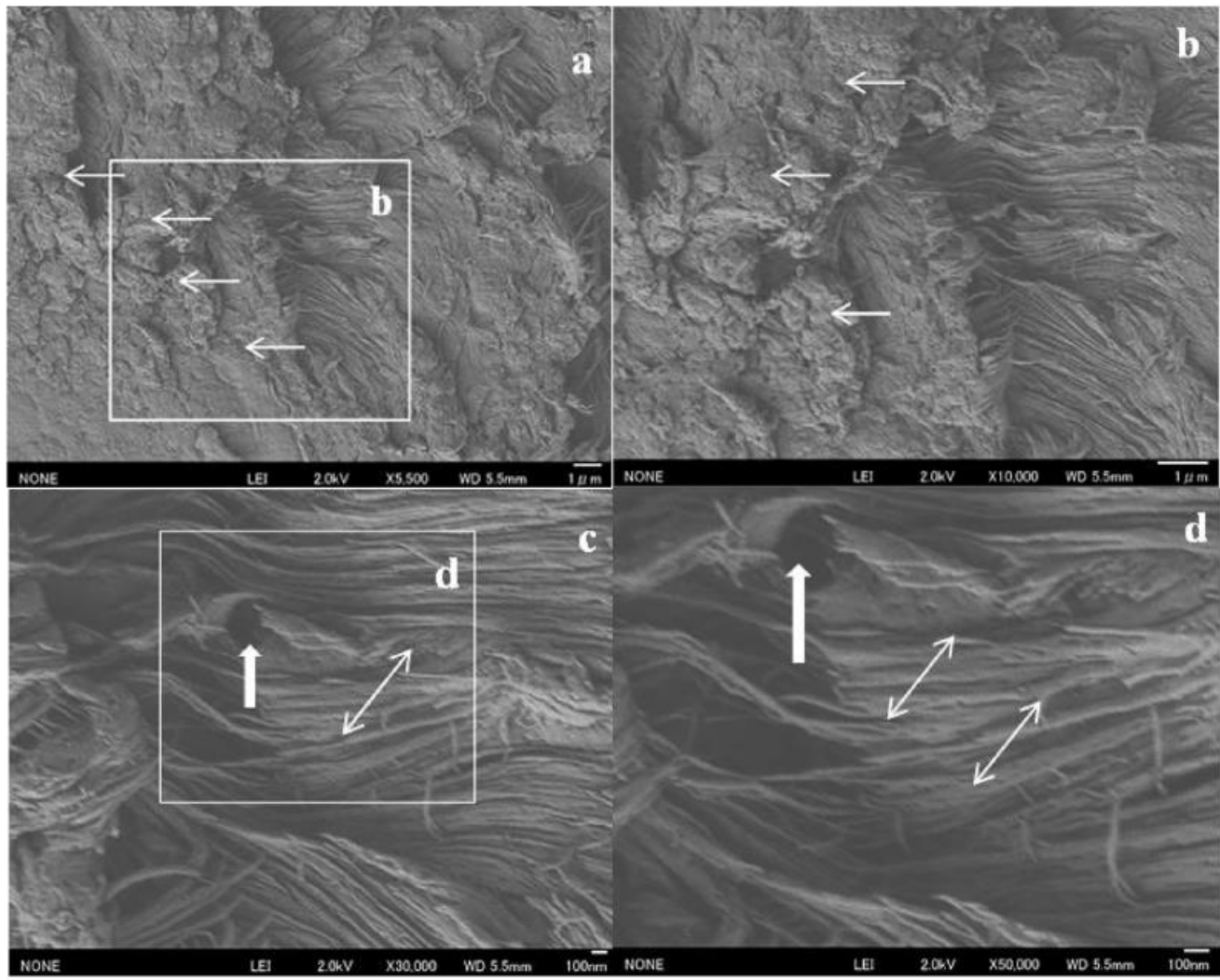

Fig. 5. FE SEM micrographs of CH from SSC of $L$ brevis $(5 \% \mathrm{v} /$ wt) and Rhizopus oligosporus (107spores $/ g$ ) at (a) $5500 \times$, (b) $10,000 \times$, (c) $30,000 \times$ and (d) $50,000 \times$. The thin, thick, and double headed arrows indicate minerals, hole, and woven chitin nanofibers.

\section{Acknowledgements}

The authors would like to thank Consejo Nacional de Ciencia y Tecnología (CONACYT Government of Mexico Project No. 237292) and Secretaría de Economía (Project No. FINNOVA/CONACYT No. 224962) for research funding and scholarship (RA).

\section{Appendix A. Supplementary data}

Supplementary data associated with this article can be found, in the online version, at http://dx.doi.org/10.1016/j.procbio.2017.04.036.

\section{References}

[1] L. Younes, M. Rinaudo, Chitin and chitosan preparation from marine sources Structure, properties and applications, Mar. Drugs 13 (2015) 1133-1174.

[2] K. Shimi, I. Guerremo, S. Huerta, G. Saucedo, A. Castillo, R.O. González, G.M. Hall, Effect of initial glucose concentration and inoculation level of lactic acid bacteria in shrimp waste ensilation, Enzyme Microb. Technol. 28 (2001) 446-452.

[3] L.A. Cira, S. Huerta, G.M. Hall, K. Shirai, Pilot scale lactic acid fermentation of shrimp wastes for chitin recovery, Process Biochem. 37 (2002) 1359-1366.

[4] N. Pacheco, M. Gámica-González, J.Y. Ramírez-Hernández, B. Flores-Albino, M. Gimeno, E. Bárzana, K. Shirai, Effect of temperature on chitin and astaxanthin recoveries from shrimp waste using lactic acid bacteria, Bioresour. Technol. 100 (2009) 2849-2854.

[5] N. Pacheco, M. Garnica-González, M. Gimeno, E. Bárzana S. Trombotto, L. David, K. Shirai, Structural characterization of chitin and chitosan obtained by biological and chemical methods, Biomacromolecules 12 (2011) 3285-3290.

[6] B. Flores-Albino, L. Arias, J. Gómez, A. Castillo, M. Gimeno, K. Shirai, Chitin and L $(+)$-lactic acid production from crab (Callinectes bellicosus) wastes by fermentation of Lactobacillus sp. B2 using sugar cane molasses as carbon source, Bioprocess Biosyst. Eng, 35 (2012) 1193-1200.

[7] M. Calasso, R. Di Cagno, M. De Angelis, D. Campanella, F. Minervivni, M. Gobbetti, Effects of the peptide pheromone plantaricin A and Cocultivation with Lactobacillus sanfranciscensis DPPMA174 on the exoproteome and the adhesion capacity of Lctobacillus plantarum DC400, Appl. Environ. Microbiol. 79 (2013) 2657-2669.

[8] P.G. Lee, L.L. Smith, A.L. Lawrence, Digestive proteases of Penaeus varnamei Boone: relationship between enzyme activity, size and diet, Aquaculture 42 (1984) $225-239$.

[9] E. Oh, D. Kim, J. Kim, H. Kim, Enzymatic properties of a protease from the hepatopancreas of shrimp, Penaeus orientalis, J. Food Biochem. 24 (2000) 251-264.

[10] J.L. Gamboa-Delgado, C. Molina-Poveda, C. Cahu, Digestive enzyme activity in juvenile Litopenaeus vannamei, Aquac Res. 34 (2003) 1403-1411.

[11] V. Narisetty, P. Ashok, B. Parameswaran, Biological valorization of pure and crude glycerol into 1,3-propanediol using a novel isolate Lactobacillus brevis N1E9.3.3, Bioresour. Technol. 213 (2016) 222-230.

[12] M. Gimeno, J.Y. Ramirez-Herníndez, C. Martínez-Ibarra, N. Pacheco, R. García Arrazola, E. Bárzana, K. Shirai, One-solvent extraction of astaxanthin from lactic acid fermented shrimp wastes, J. Agric. Food Chem. 55 (2007) 10345-10350.

[13] AOAC, Official Methods of Analysis of the Association of Official Analytical Chemists, AOAC, Washington, DC, 1980.

[14] O.H. Lowry, N.J. Rosebrough, A.I. Farr, R.J. Randall, Protein measurement with the Folin phenol reagent, J. Biol. Chem. 193 (1951) 265-275.

[15] B. Focher, Alkaline $N$-deacetylation of chitin enhanced by flash treatments, reaction kinetics and structure modifications, Carbohydr. Polym. 12 (1990) 405-418.

[16] M.L. Anson, The estimation of pepsin, trypsin, papain and cathepsin with hemoglobine, J. Gen. Physiol. (1938) 79-89.

[17] M. Kunitz, Isolation of a Crystalline protein compound of trypsin and of soybean trypsin-inhibitor, J. Gen. Physiol. (1946) 311-320.

[18] J. Trudel, A. Asselin, Detection of chitinase activity after polyacrylamide gel electrophoresis, Anal. Biochem. 178 (1998) 362-366.

[19] H. Schägger, Tricine-SDS.PAGE, Nat. Protoc. 1 (2006) 16-22.

[20] M.P. Carballo-Sánchez, J.C. Ramírez-Ramírez, M. Gimeno, G.M. Hall, M.G. RíosDurán, K. Shirai, Papaya (Carica papaya) and tuna (Thurnus albacares) by-products fermentation as biomanufacturing approach towards antioxidant protein hydrolysates, Rev. Mex. Ing. Quim. 15-1 (2016) 91-100.

[21] Y.Q. Fu, L.F. Yin, H.Y. Zhu, R. Jiang, High-efficiency L-lactic acid production by Rhizopus oryzae using a novel modified one-step fermentation strategy, Bioresour. Technol. 218 (2016) 410-417.

[22] S. Özcelik, E. Kuley, F. Özogul, Formation of lactic acetic, succinic, propionic, formic and butyric acid by lactic acid bacteria, LWT - Food Sci. Technol. 73 (2016) $536-542$.

[23] X. Mao, J. Zhang, F. Kan, Y. Gao, J. Lan, X. Zhang, Z. Hu, Y. Li, H. Lin, Antioxidant 


\section{TRABAJOS PRESENTADOS, PUBLICACIONES Y ESTANCIAS}

R. Aranday-García et al.

production and chitin recovery from shrimp head fermentation with Streptococcus thermophiles, Food Sci. Biotechnol. 22-4 (2013) 1023-1032.

[24] W.J. Jung, G.H. Jo, J.H. Kuk, K.Y. Kim, R.D. Park, Extraction of chitin from red crab shell waste by cofermentation with Lactobacillus paracasei subsp. tolerans KCTC3074 and Serratia marcescens FS-3, Appl. Microbiol. Biotechnol. 71 (2006) 234-237.

[25] P. Liu, S. Liu, N. Guo, X. Mao, H. Lin, C. Xue, D. Wei, Cofermentation of Bacillus licheniformis and Gluconobacter oxydans for chitin extraction from shrimp waste, Biochem. Eng. J. 91 (2014) 10-15.

[26] M.J.R. Nout, J.L. Kiers, Tempe fermentation, innovation and functionality: update into the third millenium, J. Appl. Microbiol. 98 (2005) 789-805.

[27] L.C. Peyer, C. Axel, K.M. Lynch, E. Zannini, F. Jacob, E. K. Arendt, Inhibition of Fusarium culmonum by carboxylic acids released from lactic acid bacteria in a barley malt substrate, Food Control 69 (2016) 227-236.

[28] X.M. Feng, A.R.B. Eriksson, J. Schnürer, Growth of lactic acid bacteria and Rhizopus oligosporus during barley tempeh fermentation, Int. J. Food Microbiol. 104 (2005) 249-256.

[29] L. Ikasari, D.A. Mitchell, Leaching and characterization of Rhizopus oligosporus acid protease from solid-state fermentation, Enzyme Microb. Technol. 19 (1996) $171-175$
Process Biochemistry 58 (2017) 17-24

[30] I.U. Haq, H. Mukhtar, Biosynthesis of proteases by Rhizopus oligosporus HS13 in low-cost medium by solid-state fermentation, J. Basic Microbiol. 44 (2004) 280-287.

[31] J. Li, L. Li, Proteolysis characteristics of Actinomucor elegans and Rhizopus oligosporus extracellular proteases under acidic conditions, Int. J. Food Sci. Technol. 48 (2013) 512-518.

[32] J.S. Lin, S.K. Lee, Y. Chen, W.D. Lin, C.H. Kao, Purification and characterization of a novel extracellular tripeptidyl peptidase from Rhizopus oligosponus, J. Agric. Food novel extracellular tripeptidyl $\mathrm{p}$.

[33] J. Je, Z. Qian, H. Byun, S.K. Kim, Purification and characterization of an antioxidant peptide obtained from tuna backbone protein by enzymatic hydrolysis, Process Biochem. 42 (2007) 840-846.

[34] S. Ifuku, M. Nogi, K. Abe, M. Yoshioka, M. Morimoto, H. Saimoto, Y. Hiroyuki, Preparation of chitin nanofibers with a uniform width as alpha-chitin from crab shells, Biomacromolecules 10 (2009) 1584-1588.

[35] R. Chandran, L. Williams, A. Hung, K. Nowlin, D. La Jeunesse, SEM characterization of anatomical variation in chitin organization in insect and arthropod cuticles, Micron 82 (2016) 74-85. 


\section{BIBLIOGRAFÍA}

1. Anuario Estadístico de Acuacultura y Pesca (2012). Comisión Nacional de Acuacultura y Pesca. Secretaría de Agricultura, Ganadería, Desarrollo Rural, Pesca y Alimentación.

2. Agulló, E., Rodríguez, M.S., Ramos, V., Albertengo, L. (2003). Present and future role of chitin and chitosan in food. Macromolecular Bioscience. 3:521-530.

3. Amund, O.O., Omidiji, O., Ilori, O. (1990). Purification and properties of a neutral protease produced by Lactobacillus brevis. Journal of Biotechnology. 13:361-365.

4. Anson, M.L. (1938). The estimation of pepsin, trypsin, papain and cathepsin with hemoglobine. Journal of general physiology. 79-89.

5. AOAC. (1990). Official methods of analysis. Association of Official Analytical Chemists, Washington, D.C. 13th edition.

6. Aranday-García, R. (2013). Obtención de quitina a partir de desechos pesqueros mediante un sistema de cultivo con Rhizopus oligosporus y Lactobacillus spp. Tesis para obtener título de Maestría en Biotecnología. Universidad Autónoma Metropolitana Iztapalapa, México.

7. Aranday-García, R., Román, G.A., Shirai, K., Ifuku, S. (2017). Successive inoculation of Lactobacillus brevis and Rhizopus oligosporus on shrimp wastes for recovery of chitin and added-value products. Process biochemistry. 58:17-24.

8. Bell, D.J., Blake, J.D., Prazak, M., Rowell, D., Willson, P.N. (1991) Studies on yeast differentiation using organic acids metabolites. Part 1: development of methodology using High Performance Liquid Cromatography. Journal of the Institute of Brewing. 92:297-305.

9. Bof, M.J., Bordagaray, V.C., Locaso, D.E., García, M.A. (2015). Chitosan molecular weight effect on starch-composite film properties. Food Hydrocolloids. 51:281-294.

10. Centeno, B. S., Rodríguez, B.R. (2007). Actividad enzimática de bacterias frecuentes en camarones (Litopenaeus schmitti), mejillones (Perna viridis) y calamares (Loligoplei) congelados producidos en Cumaná, Estado Sucre, Venezuela. Revista de la Sociedad Venezolana de Microbiología. 27 no.1.

11. Cira, L.A., Huerta, S., Hall, G.M., Shirai, K. (2002). Pilot scale lactic acid fermentation of shrimp wastes for chitin recovery. Process Biochemistry. 37:1359-1366.

12. Dutta, A.K., Kawamoto, N., Sugino, G., Izawa, H., Morimoto, M., Saimoto, H., \& Ifuku, S. (2013). Simple preparation of chitosan nanofibers from dry chitosan powder by the Star Bust System. Carbohydrate Polymers. 97:363-367.

13. Feng, X.M., Eriksson, A.R.B., Schnürer, J. (2005) Growth of lactic acid bacteria and Rhizopus oligosporus during barley tempeh fermentation. International Journal of Food Microbiology. 104:249-256. 
14. Fernández-Martín, F., Arancibia, M., López-Caballero, E., Gómez-Guillén, C., Montero, P., Fernández-García, M. (2014). Preparation and molecular characterization of chitosans obtained from shrimp (Litopenaeus vannamei) shells. Journal of Food Science. 7(9):1722-1731.

15. Flores-Albino, B., Arias, L., Gómez, J., Castillo, A., Gimeno, M., Shirai, K. (2012). Chitin and $\mathrm{L}(+)$-lactic acid production from crab (Callinectes bellicosus) wastes by fermentation of Lactobacillus sp. B2 using sugar cane molasses as carbon source. Bioprocess and Biosystems Engineering. 35:1193-1200.

16. Fu-Chien, L., Chung-Ren S., Tzi-Yi W., Shyh-Gang S., Huey-Lang Y, Han-You L.J., TianShung W. (2011). Efficient $1 \mathrm{H}-\mathrm{NMR}$ Quantitation and investigation of N-Acetyl-Dglucosamine (GlcNAc) and N,N'-Diacetylchitobiose (GlcNAc)2 from chitin. International Journal of Molecular Sciences. 12:5828-5843.

17. Gimeno, M., Ramírez-Hernández, J.Y., Martínez-Ibarra, C., Pacheco, N., GarcíaArrazola, R., Bárzana, E., Shirai, K. (2007) One-solvent extraction of astaxanthin from lactic acid fermented shrimp wastes. Journal of Agricultural and Food Chemistry. 55:10345-10350.

18. Ghorbel-Bellaaj, O., Younes, I., Maâlej, H., Hajji, S., Nasri, M. (2012). Chitin extraction from shrimp shell waste using Bacillus bacteria. International Journal of Biological Macromolecules. 51:1196-1201.

19. González-Rábade, N., Badillo-Corona, J., Arranda-Barradas, J., Oliver-Salvador, M. (2011). Production of plant proteases in vivo and in vitro - A review. Biotechnology Advances. 29:983-996.

20. Goswami, G., Chaudhuri, S., Dutta, D. (2010). The present perspective of astaxanthin with reference to biosynthesis and pharmacological importance. World Journal of Microbiology and Biotechnology. 26:1925-1939.

21. Guo, Y., Yan, Q., Jian, Z., Teng, C., Wang, X. (2010). Efficient production of lactic acid from sucrose and corncob hydrolysate by a newly isolated Rhizopus oryzae GY18. Journal of Industrial Microbiology and Biotechnology. 37:1137-1143.

22. Hajji, S., Younes, I., Ghorbel-Bellaaj, O., Hajji, R., Rinaudo, M., Nasri, M., \& Jellouli, K. (2014). Structural differences between chitin and chitosan extracted from three different marine sources. International Journal of Biological Macromolecules. 65: 298-306.

23. Haq, I.U., Mukhtar, H. (2004). Biosynthesis of proteases by Rhizopus oligosporus IHS13 in low-cost medium by solid-state fermentation. J. Basic Microbiol. 44(280287). 


\section{BIBLIOGRAFÍA}

24. Higuera-Ciapara, I., Félix-Valenzuela, L., Goycoolea, F.M. (2006). Astaxanthin: A Review of its Chemistry and Applications. Critical Reviews in Food Science and Nutrition. 46:185-196.

25. Hirano S. (1999). Chitin and chitosan as novel biotechnological materials. Polymer International. 48: 732-734.

26. Honary, S., Maleki, M., Karami, M. (2009). The effect of chitosan molecular weight on the properties of alginate/ chitosan microparticles containing prednisolone. Tropical Journal of Pharmaceutical Research. 8 (1): 53-61.

27. Huang, L.P., Jin, B., Lant, P., Zhou, J. (2003). Biotechnological production of lactic acid integrated with potato wastewater treatment by Rhizopus arrhizus. Journal of Chemical Technology and Biotechnology. 78:899-906.

28. Ifuku, S., Nogi, M., Abe, K., Yoshioka, M., Morimoto, M., Saimoto, S., Yano, H. (2009). Preparation of Chitin Nanofibers with a Uniform Width as r-Chitin from Crab Shells. Biomacromolecules. 10:1584-1588.

29. Ifuku, S., Saimoto, H. (2012). Chitin nanofibers: preparations, modifications, and applications. Nanoscale. 4:3308-3318.

30. Ifuku, S., Yamada, K., Morimoto, M., Saimoto, H. (2012). Nanofibrillation of dry chitin powder by Star Burst System. Journal of Nanomaterials. 1-7. ID 645624. doi:10.1155/2012/645624

31. Ikasari, L., Mitchell, D.A. (1996). Leaching and characterization of Rhizopus oligosporus acid protease from solid-state fermentation. Enzyme and Microbial Technology. 19(171-175).

32. loelovich, M. (2014). Crystallinity and hydrophility of chitin and chitosan. Research and Reviews: Journal of Chemistry. 3(7-14).

33. Jian-Bing, Z., Yi-Song, H., Shao-Long, L., Yu-Zhong, W. (2011). Chitin Whiskers: An Overview. Biomacromolecules. 13:1-11.

34. Jiang, L., Pan, S., Kimb, M.J. (2011). Influence of nitrogen source on chitosan production carried out by Absidia coerulea CTCC AF 93105. Carbohydrate Polymers 86:359- 361.

35. Juárez, C.C.J., (2012). Obtención y caracterización de quitina biológica y su desacetilación a quitosano. Tesis para obtención de grado maestría en biotecnología. Universidad Autónoma Metropolitana Iztapalapa, México.

36. Jung, W.J., Jo, G. H., Kuk, J.H., Kim, K.Y., Park, R.D. (2006). Extraction of chitin from red crab shell waste by cofermentation with Lactobacillus paracasei subsp. tolerans KCTC-3074 and Serratia marcenses FS-3. Applied Microbioogy and Biotechnology. 71:234-237. 


\section{BIBLIOGRAFÍA}

37. Kassai, R.M. (2008). A review of several reported procedures to determine the degree of $\mathrm{N}$-acetylation for chitin and chitosan using infrared spectroscopy. Carbohydrate Polymers. 71: 497-508.

38. Kaya, M., Baran, T., Saman, I., Ozusaglam, M.A., Cakmak, Y.S., Mentes, A. (2014). Physicochemical characterization of chitin and chitin obtained from resting eggs of Ceriodaphnia quadrangular (Branchiopoda: Cladocera: Daphniidae). Journal of Crustacean Biology. 34:283-288.

39. Kumar, M.N.V.R. (2000). A review of chitin and chitosan applications. Reactive \& Functional Polymers. 46:1-27.

40. Kunitz M. (1947). Isolation of a crystalline protein compound of trypsin and of soybean trypsin-inhibitor. Journal of General Physiology. 30:291-310.

41. Kurita, K. (2001). Controlled functionalization of the polysaccharide chitin. Progress in Polymer Science. 26:1921-1971.

42. Lamarque, G.; Viton, C.; Domard, A. (2004). Comparative study of the second and third heterogeneous deacetylation of alfa- and beta- chitins in a multistep process. Biomacromolecules. 5: 1899-1907.

43. Li, J., Li, L., (2013). Proteolysis characteristics of Actinomucor elegans and Rhizopus oligosporus extracellular proteases under acidic conditions. International Journal of Food Science and Technology. 48:512-518.

44. Li, J., Wu, Y., Zhao, L. (2016). Antibacterial activity and mechanism of chitosan with ultra high molecular weight. Carbohydrate Polymers. 148:200-205.

45. Liu, P., Liu, S., Guo, N., Mao, X., Lin, H., Xue, C., Wei, D. (2014). Cofermentation of Bacillus licheniformis and Gluconobacter oxydans for chitin extraction from shrimp waste. Biochemical Engineering Journal. 91:10-15.

46. Lu, Y., Sun, Q., She, X., Xia, Y., Liu, Y., Li, J., \& Yang, D. (2013). Fabrication and characterisation of $\alpha$-chitin nanofibers and highly transparent chitin films by pulsed ultrasonication. Carbohydrate Polymers. 98:1497- 1504.

47. Luquet, G., Marin, F. (2004). Biomineralisations in crustaceans: storage strategies. Comptes Rendus Palevol. 3(6-7): 515-534.

48. Mao, X., Zhang, J., Kan, F., Gao, Y., Lan, J., Zhang, X., Hu, Z., Li, Y., Lin, H. (2013). Antioxidant Production and Chitin Recovery from Shrimp Head Fermentation with Streptococcus thermophilus. Food and Science Biotechnology. 22:1023-1032.

49. Mayren, G. A., (2013) Obtención de Quitina y Quitosano a partir de desperdicio de camarón por medio de desproteinización enzimática. Tesis para obtención de grado Químico Farmacéutico Biólogo. Facultad de Estudios Superiores Zaragoza, UNAM, México. 


\section{BIBLIOGRAFÍA}

50. Motta de Moura, C., Motta de Moura, J., Madeira, S.N., De Almeida, P. L. A. (2011). Evaluation of molar weight and deacetylation degree of chitosan during chitindeacetylation reaction: Used to produce biofilm. Chemical Engineering and Processing. 50:351-355.

51. Niamnuy C., Devahastin S. and Soponronnarit S. (2008). Changes in protein compositions and their effects on physical changes of shrimp during boiling in salt solution. Food Chemistry. 108: 165-175.

52. Özcelik, S., Kuley, E., Özogul, F. (2016). Formation of lactic, acetic, succinic, propionic, formic and butyric acid by lactic acid bacteria. LWT - Food Science and Technology. 73:536-542.

53. Pacheco, N., Gárnica-González, M., Ramírez-Hernández, J.Y., Flores-Albino, B., Gimeno, M., Bárzana, E., Shirai, K. (2009). Effect of temperature on chitin and astaxanthin recoveries from shrimp waste using lactic acid bacteria. Bioresource Technology. 100:2849-2854.

54. Pacheco, N., Garnica-González, M., Gimeno, M., Bárzana, E., Trombotto, S., David, L., Shirai, K. (2011). Structural characterization of chitin and chitosan obtained by biological and chemical methods. Biomacromolecules. 12:3285-3290.

55. Palma, M.J., Sandalio, M.L., Corpas, J.F., Romero-Puertas, C.M., McCarthy, I., Del Río, A. L. (2002). Plant proteases, protein degradation, and oxidative stress: role of peroxisomes. Plant Physiology Biochemistry. 40:521-530.

56. Peyer, L.C., Axel, C., Lynch, K.M., Zannini, E., Jacob, F., Arendt, E.K. (2016) Inhibition of Fusarium culmorum by carboxylic acids released from lactic acid bacteria in a barley malt substrate. Food Control. 69:227-236.

57. Pillai, C.K.S., Paul, W., Sharma, C.P. (2009). Chitin and chitosan polymers: Chemistry, solubility and fiber formation. Progress in Polymer Science. 34: 641678.

58. Phrueksawan, P., Kulpreecha, S., Sooksai, S., Thongchul, N. (2012). Direct fermentation of $\mathrm{L}(+)$-lactic acid from cassava pulp by solid state culture of Rhizopus oryzae. Bioprocess Biosystems Engineering. 35:1429-1436.

59. Raabe, D., Sachs, C., Romano, P. (2005). The crustacean exoskeleton as an example of a structurally and mechanically graded biological nanocomposite material. Acta Materialia. 53:4281-4292

60. Raabe, D., Romano, P., Sachs, C., Fabritius, H., Al-Sawalmih, A., Yi, S.-B., Serbos, G., Hartwig, H. G. (2006). Microstructure and crystallographic texture of the chitinprotein network in the biological composite material of the exoskeleton of the lobster Homarus americanus. Materials Science and Engineering. A, 421(1-2): 143153. 


\section{BIBLIOGRAFÍA}

61. Rahman M.A., Halfar, J. (2014). First evidence of chitin in calcified coralline algae: new insights into the calcification process of Clathromorphum compactum. Nature: Scientific Report. 4, 6162, DOI: 10.1038/srep06162.

62. Ramírez-Coutiño, L.; Marín-Cervantez, M.C., Huerta, S., Revah, S., Shirai, K. (2006). Enzymatic hydrolysis of chitin in the production of oligosaccharides using Lecanicillium fungicola chitinases. Process Biochemistry. 41:1106-1110.

63. Ranga R.A., Phang, S.M., Ravi, S., Aswathanarayana, R.G. (2014). Astaxanthin: Sources, Extraction, Stability, Biological Activities and Its Commercial Applications-A Review. Marine Drugs.12:128-152.

64. Rawlings, N.D., Barrett, A.J. (1999). MEROPS: the peptidase database. Nucleic Acids Research. 27:325-331.

65. Roubos-van den Hil, P.J., Dalmas, E., Nout, M.J.R., Abee, T. (2009). Soya bean tempe extracts show antibacterial activity against Bacillus cereus cells and spores. Journal of applied microbiology. 109:137-145.

66. Salaberria, A.M., Fernandes, S.C.M., Herrera, D.R., Labidi, J. (2015). Processing of chitin nanofibers by dynamic high pressurehomogenization: Characterization and antifungal activity against $A$. niger. Carbohidrate Polymers. 116:286-291.

67. Seoudi, R., Nada, A.M.A. (2007). Molecular structure and dielectric properties studies of chitin and its treated by acid, base and hypoclorite. Carbohydrate polymers. 68:728-733.

68. Shägger, H. (2006). Tricine-SDS-PAGE. Nature Protocols. doi:10.1038/nprot.2006.4.

69. Shirai, K., Guerrero, I., Huerta, S., Saucedo, G., Castillo, A., González, R.O., Hall, G.M. (2001). Effect of initial glucose concentration and inoculation level of lactic acid bacteria in shrimp waste ensilation. Enzyme and Microbial Technology. 28:446-452.

70. Takaya, N., Yamazaki, D., Horiuchi, H., Ohta, A., Takagi, M. (1998). Intracellular chitinase gene from Rhizopus oligosporus: molecular cloning and characterization. Microbiology, 144:2647-2654.

71. Taylor, J. R. A., Gilleard, J. M., Allen, M. C., \& Deheyn, D.D. (2015) Effects of $\mathrm{CO}_{2-}$ induced $\mathrm{pH}$ reduction on the exoskeleton structure and biophotonic properties of the shrimp Lysmata californica. Nature: Scientific Reports. 5: 10608.

72. Teng, W.E., Khor, E., Tan, T.K., Lim, L.Y., Tan, S.C. (2001). Concurrent production of chitin from shrimp shells and Fungi. Carbohydrate Research. 332(305-316).

73. Weinhold, M.X., Sauvageau, J.C.M., Kumirska, J., Thöming, J. (2009). Studies on acetylation patterns of different chitosan preparations. Carbohydrate polymers. 78:678-684. 


\section{BIBLIOGRAFÍA}

74. Yaghobi, N., Mirzadeh, H. (2004). Enhancement of Chitins Degree of Deacetylation by Multistage Alkali Treatments. Iranian Polymer Journal. 13: 131-136.

75. Yeul, V.S., Rayalu, S.S. (2013). Unprecedented Chitin and Chitosan: A Chemical Overview. Journal of Polymers and the Enviroment. 21:606-614.

76. Younes, I., Ghorbel-Bellaaja, O., Nasria, R., Chaabounib, M., Rinaudo, M., Nasria, M. (2012). Chitin and chitosan preparation from shrimp shells using optimized enzymatic deproteinization. Process Biochemistry. 47:2032-2039.

77. Younes, I., Rinaudo, M. (2015). Chitin and Chitosan Preparation from Marine Sources. Structure, Properties and Applications. Marine Drugs. 13: 1133-1174.

78. Yuan, Y., Chesnutt, B.M., Haggard, W.O., Bumgardner, J.D. (2011). Deacetylation of Chitosan: Material Characterization and in vitro Evaluation via Albumin Adsorption and Pre-Osteoblastic Cell Cultures. Materials. 4:1399-1416.

79. Zawadzki, J., Kaczmarek, H. (2010). Thermal treatment of chitosan in various conditions. Carbohydrate Polymers. 80:394-400.

80. Zhang, Z., Xie, Y., Xu, X., Pan, H., \& Tang, R. (2012). Transformation of amorphous calcium carbonate into aragonite. Journal of Crystal Growth. 343(1): 62-67.

81. Zhang, W., Yang, R., Zhao, W., Hua, X., Zhang, W. (2013). Application of high density steam flash-explosion in protein extraction of soybean meal. Journal of Food Engineering. 116:430-435.

82. Zheng, L.Y.; Zhu. J.F. (2003) Study on antimicrobial activity of chitosan with different molecular weights. Carbohydrate Polymers. 54:527-530. 


\section{Anexo I}

CURVAS PATRÓN

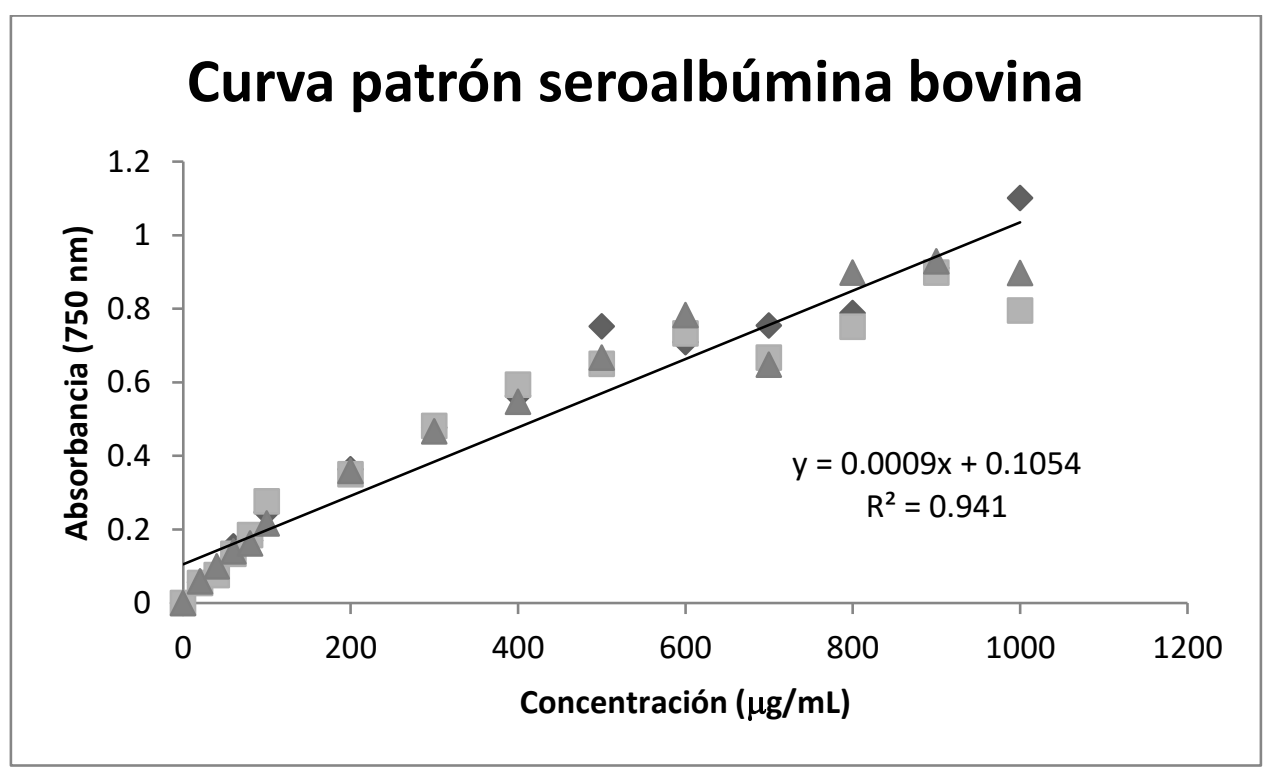

Fig. 37. Curva patrón de seroalbúmina bovina para determinación de proteína soluble mediante Lowry-Peterson 


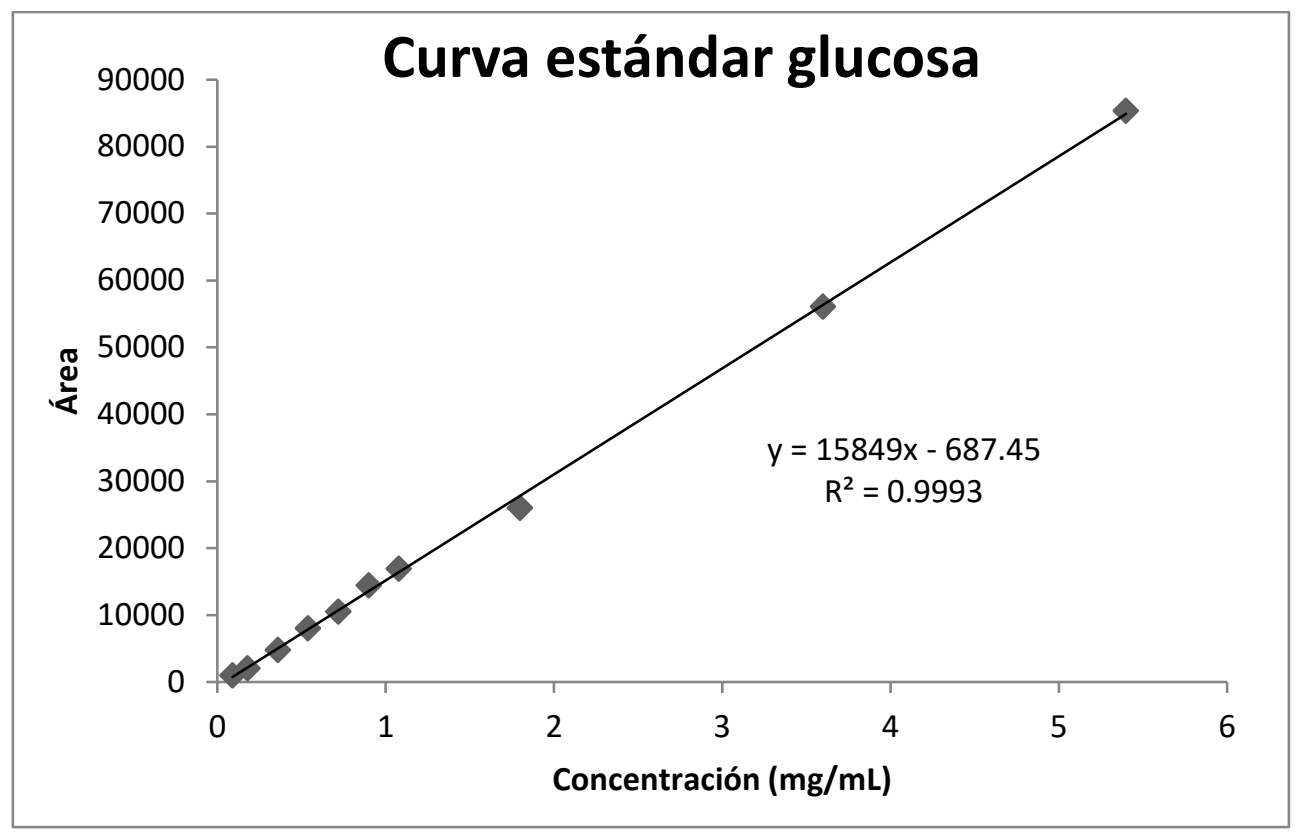

Fig. 38. Curva estándar de glucosa determinada mediante HPLC

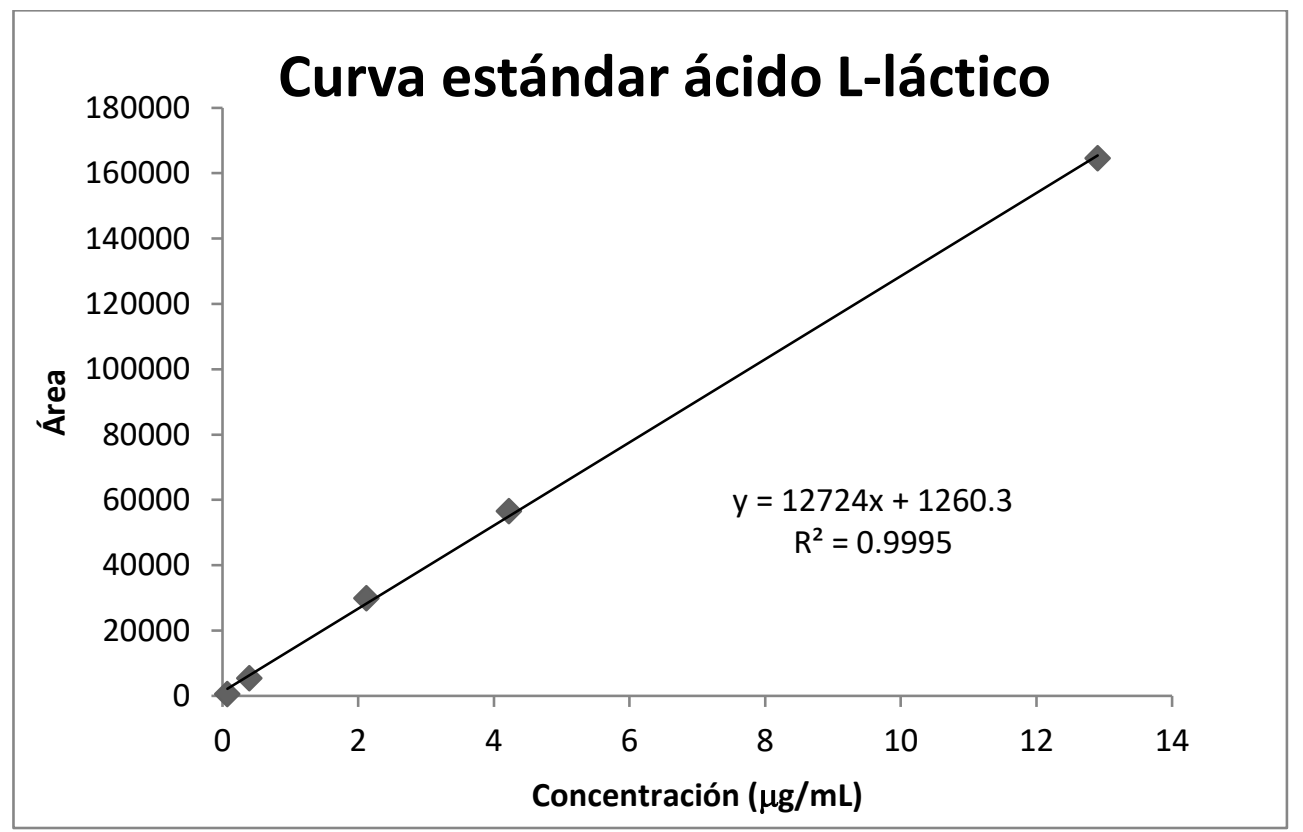

Fig. 39. Curva estándar de ácido L-láctico determinada mediante HPLC 


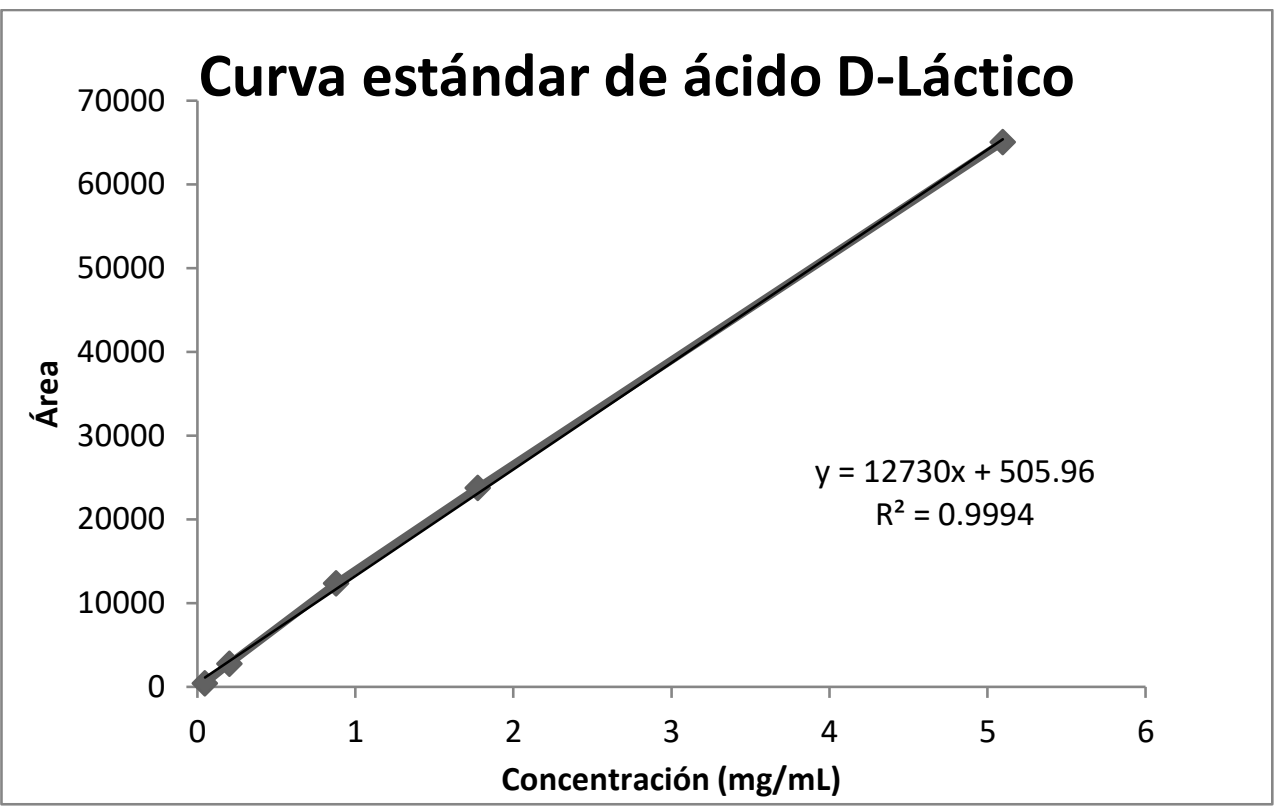

Fig. 40. Curva estándar de ácido D-Láctico determinada mediante HPLC

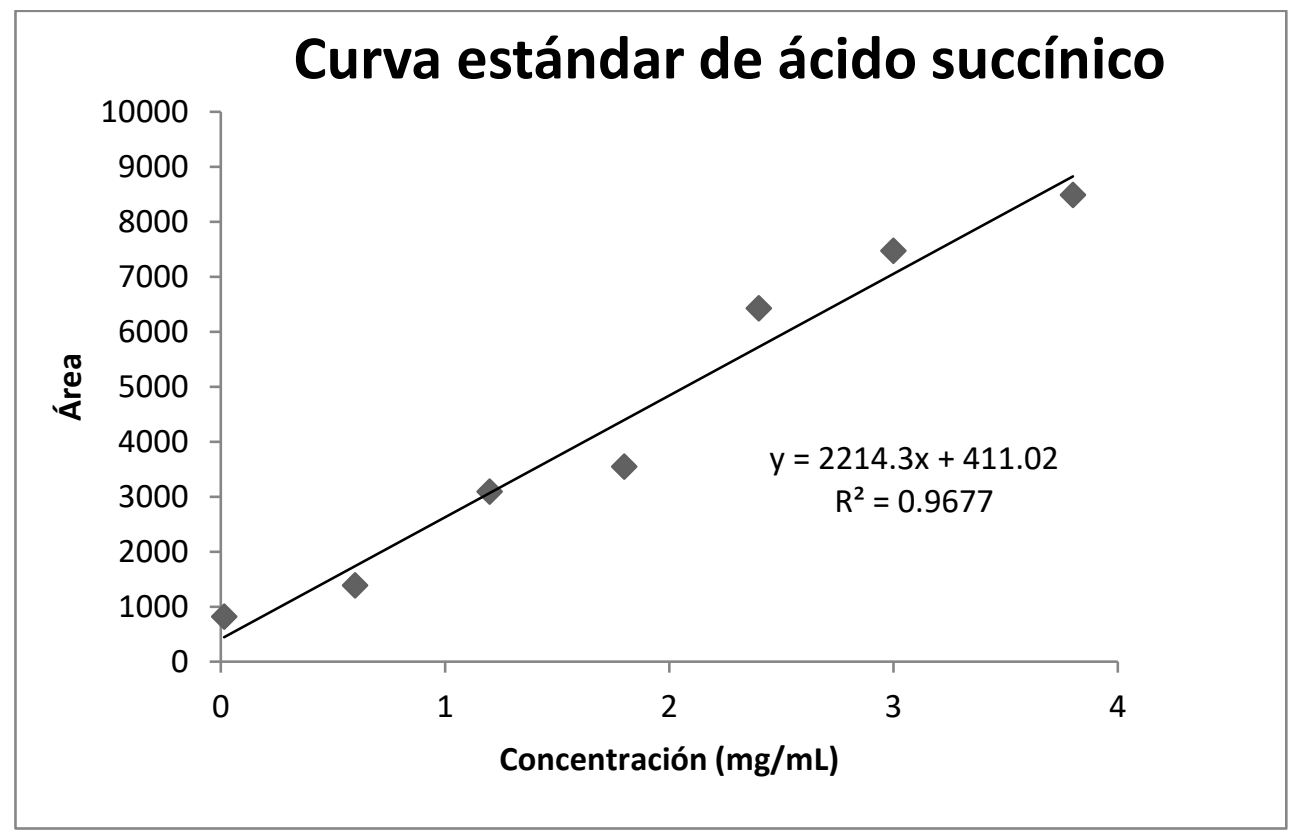

Fig. 41. Curva estándar de ácido succínico determinada mediante HPLC 


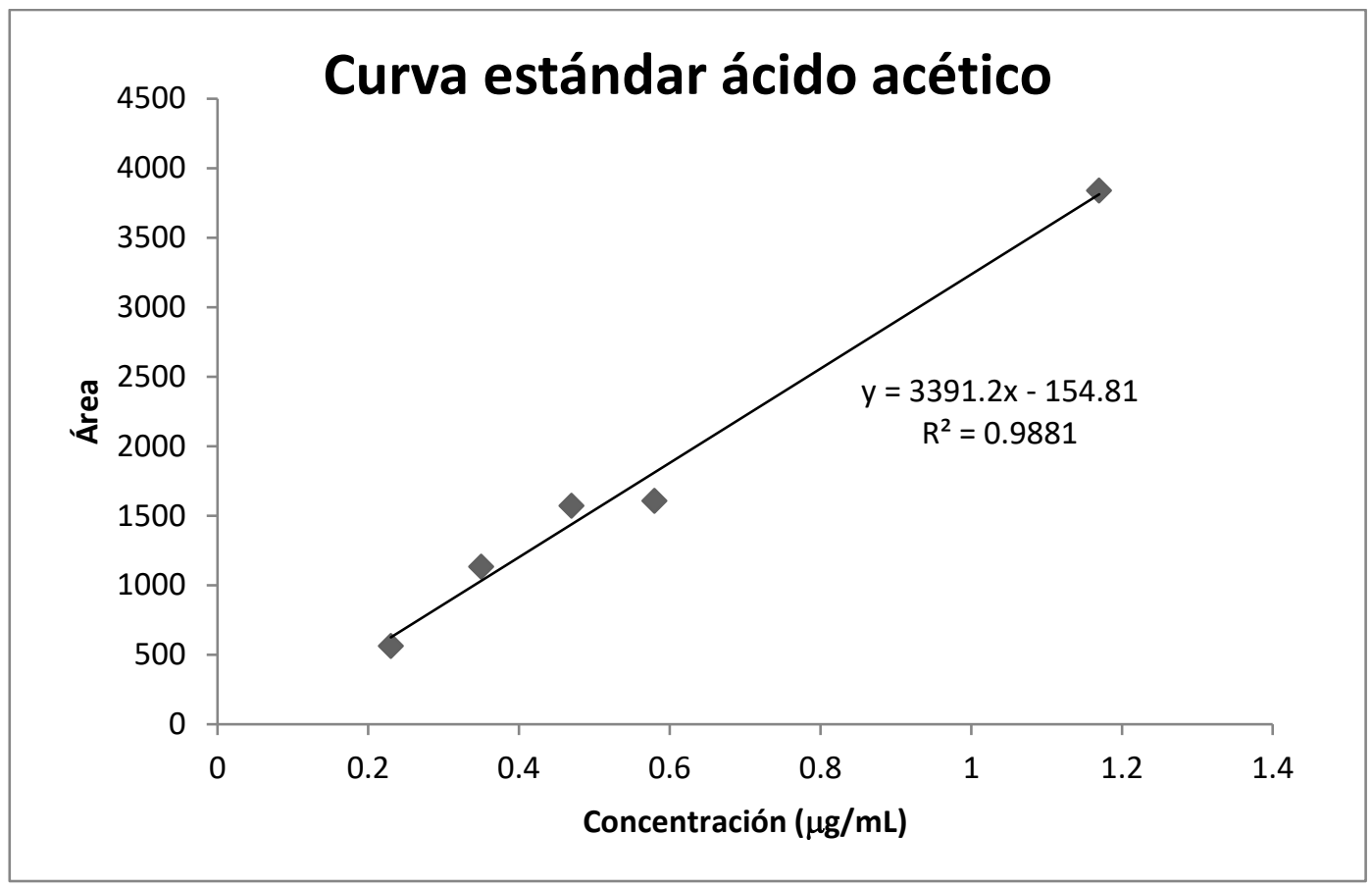

Fig. 42. Curva estándar de ácido acético determinada mediante HPLC

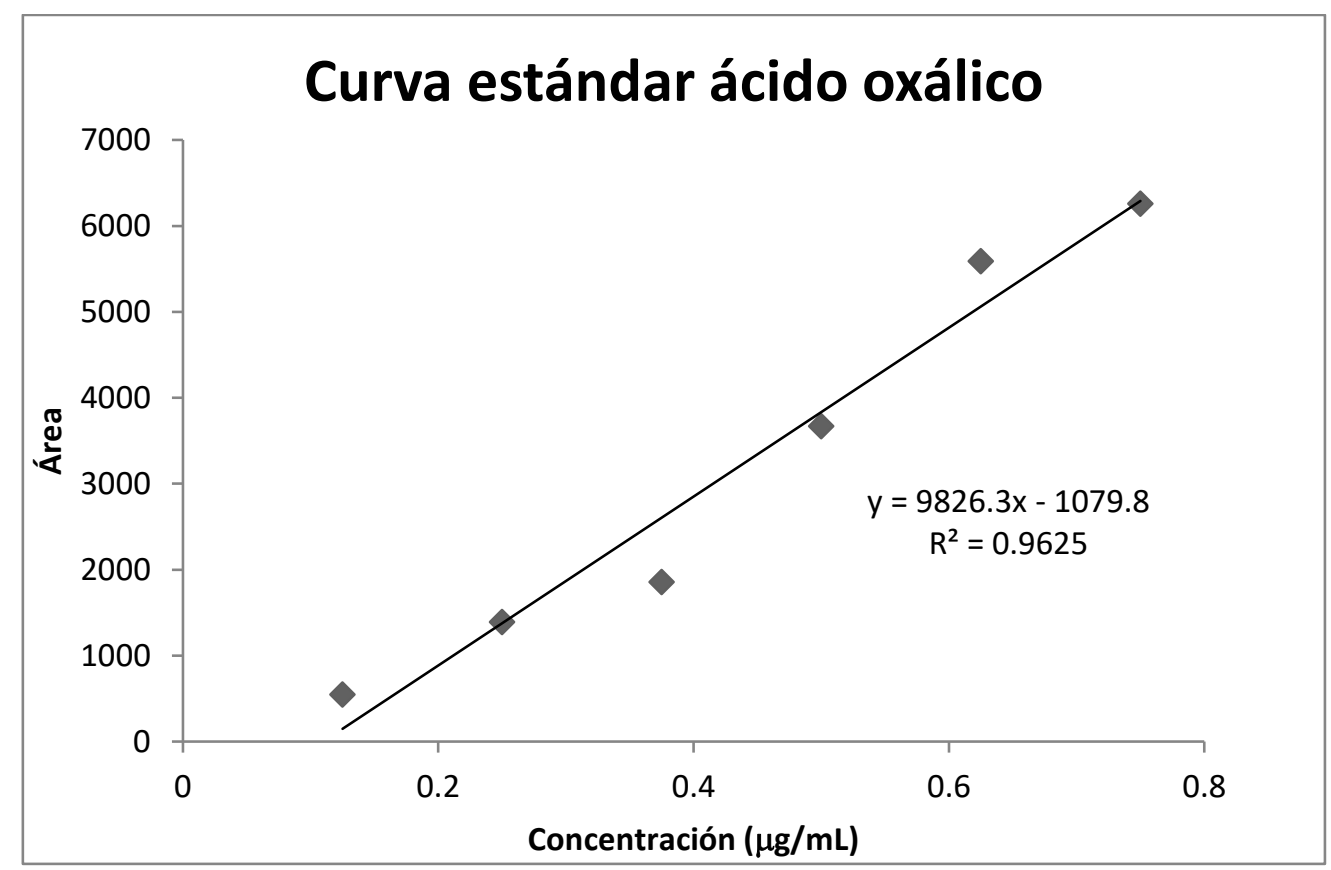

Fig. 43. Curva patrón de ácido oxálico determinada mediante HPLC 


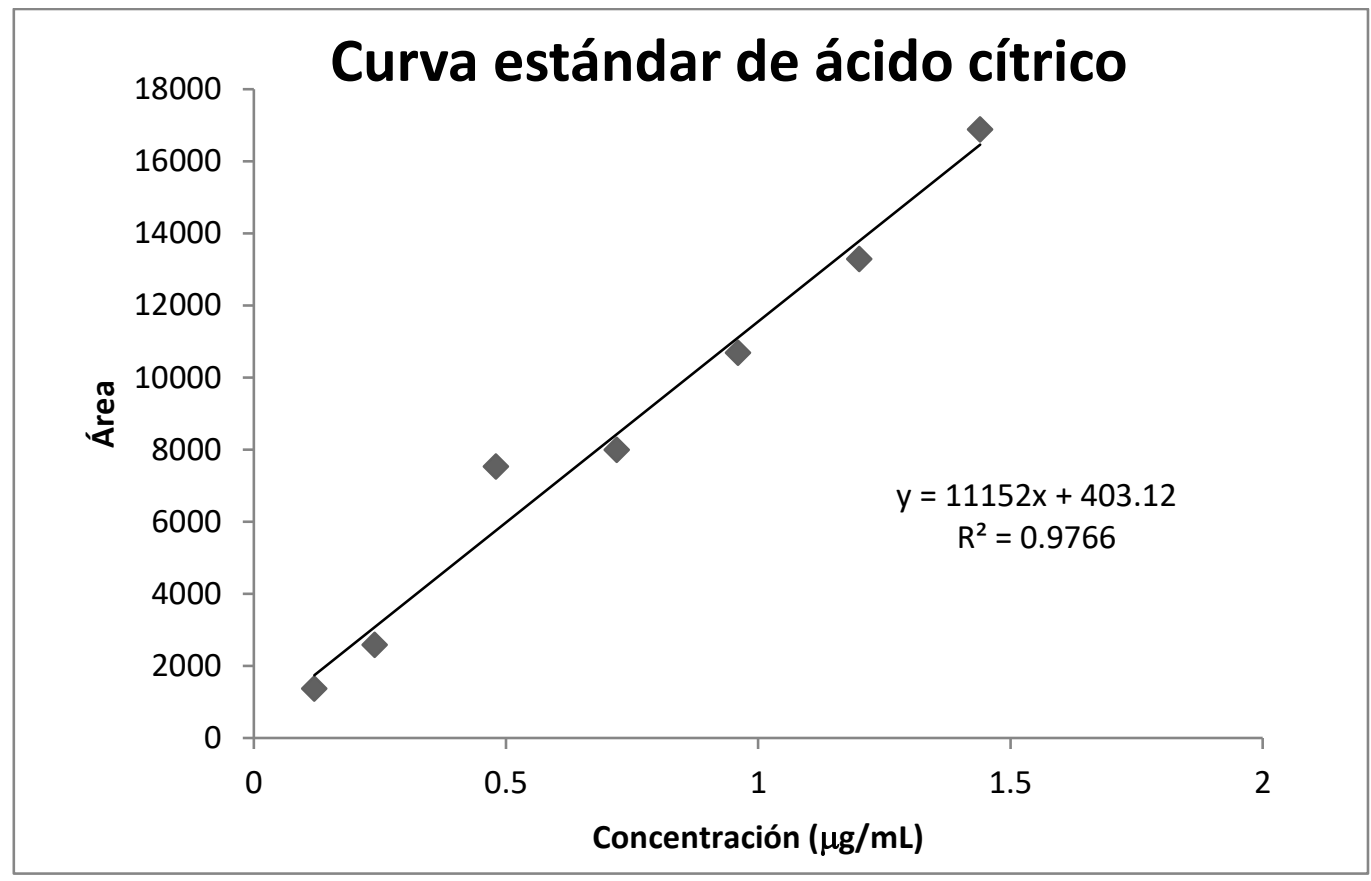

Fig. 44. Curva estándar de ácido cítrico determinada mediante HPLC

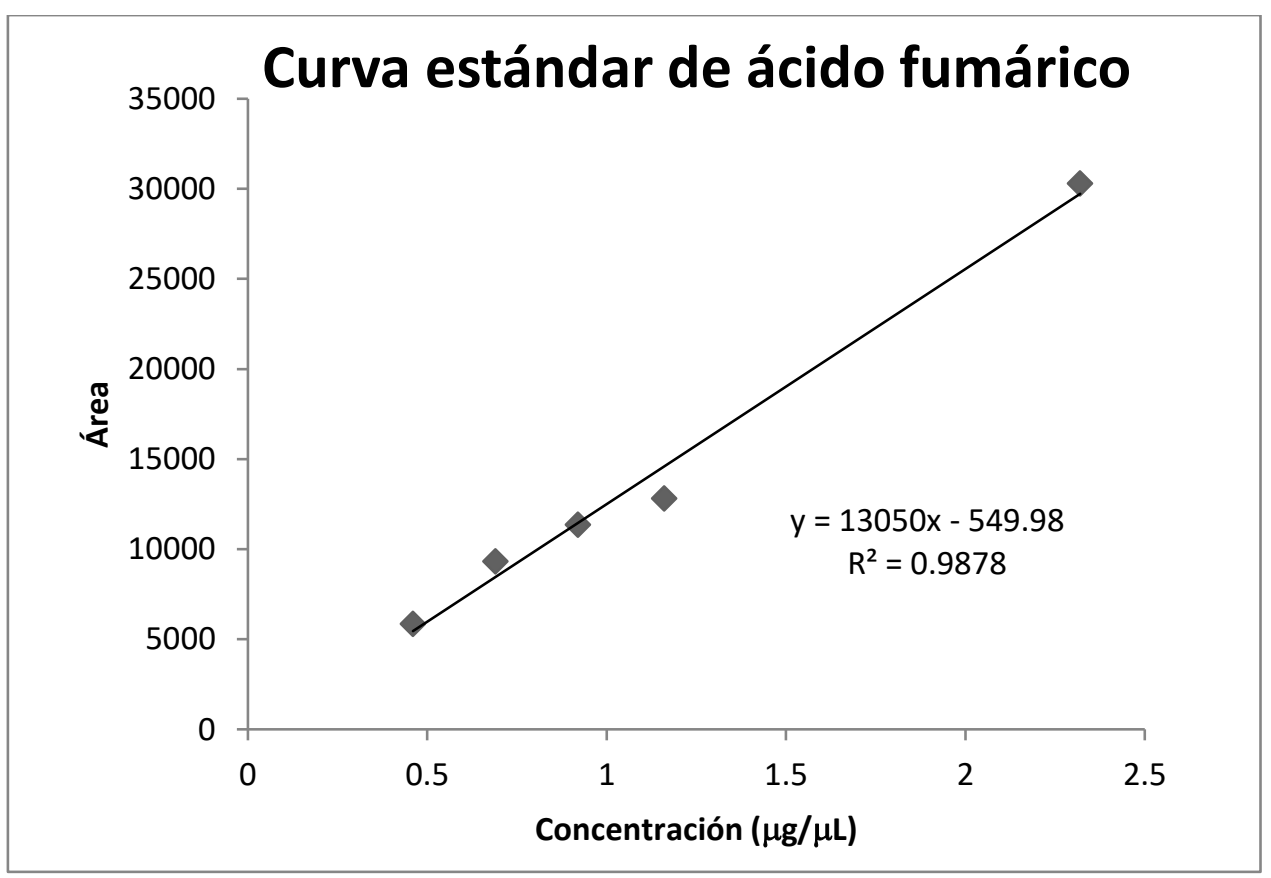

Fig. 45. Curva estándar de ácido fumárico determinada mediante HPLC 


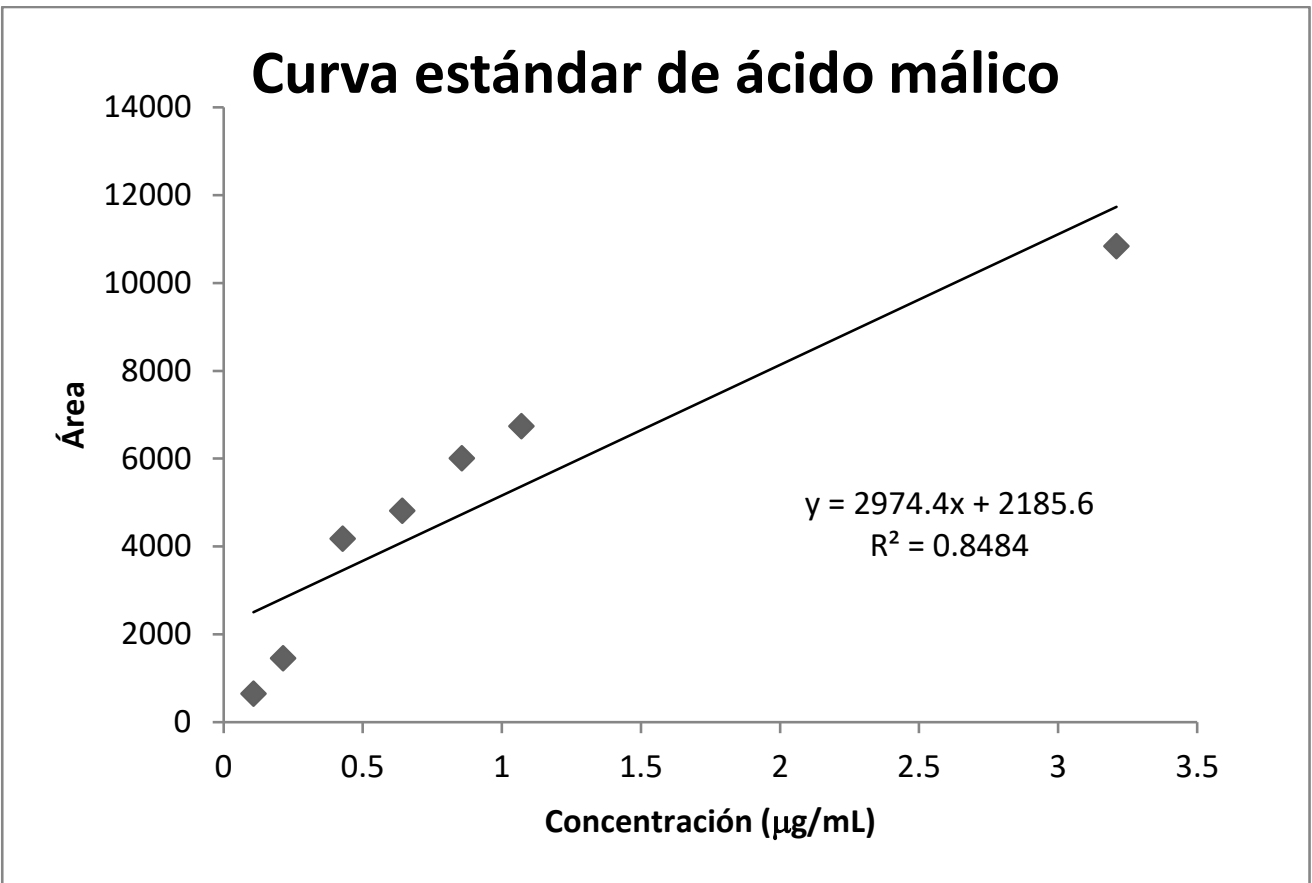

Fig. 46. Curva estándar de ácido málico determinada mediante HPLC

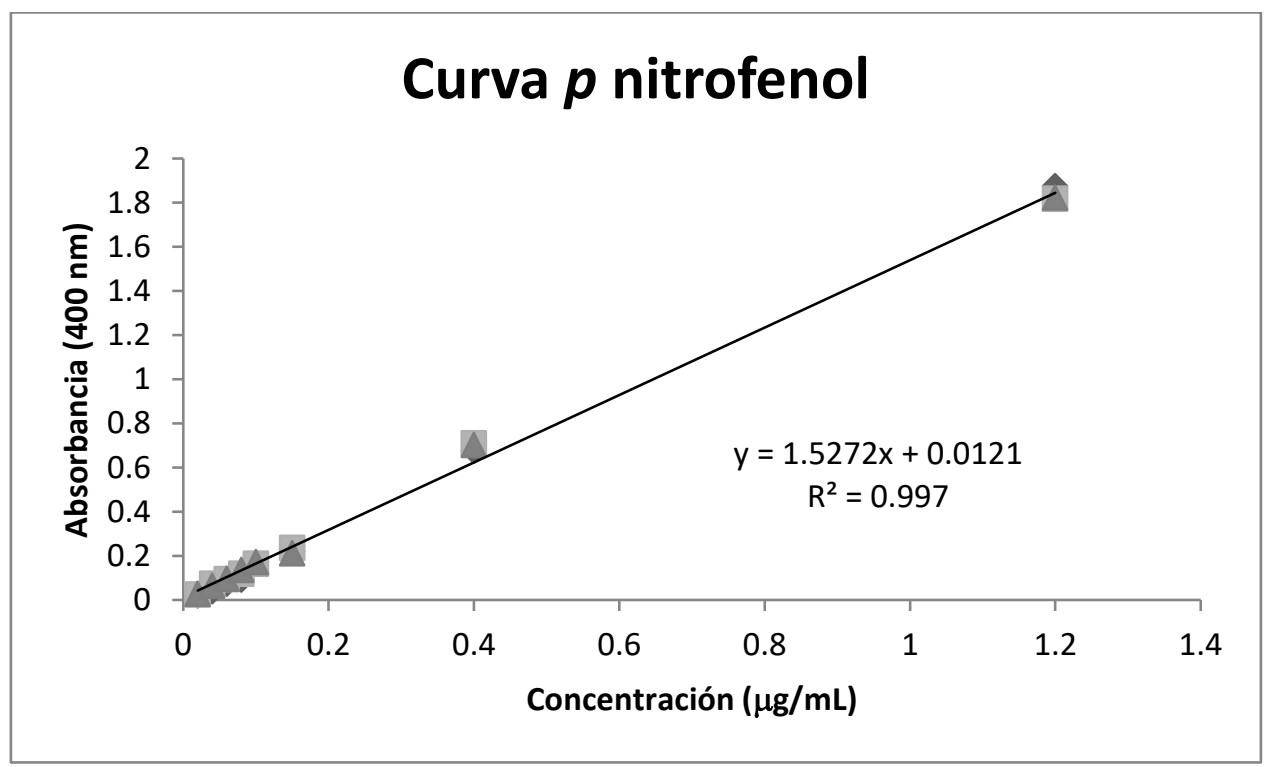

Fig. 47. Curva de $p$ nitrofenol para determinación de $\mathrm{N}$-acetil hexosaminidasa 


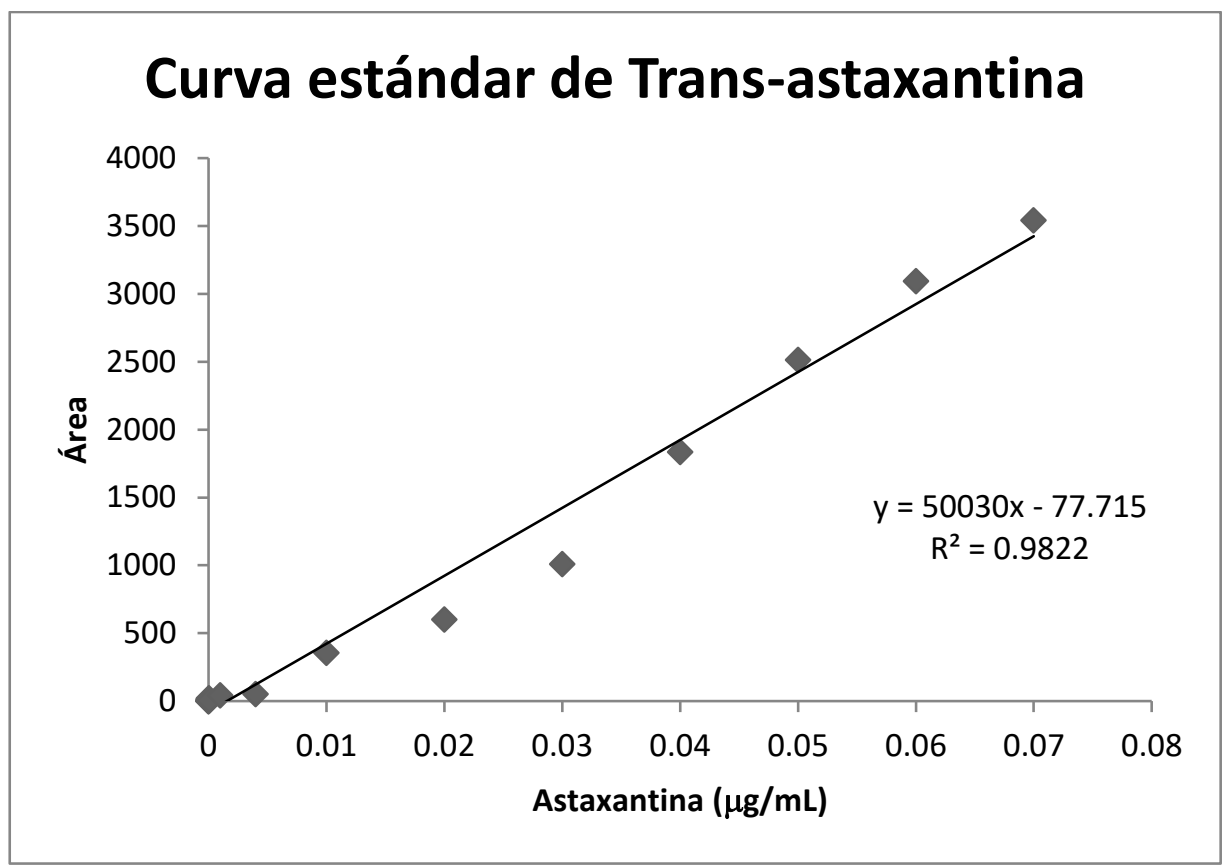

Fig. 48. Curva estándar de Trans-astaxantina determinada mediante HPLC 


\section{Anexo II}

\section{Cromatogramas}

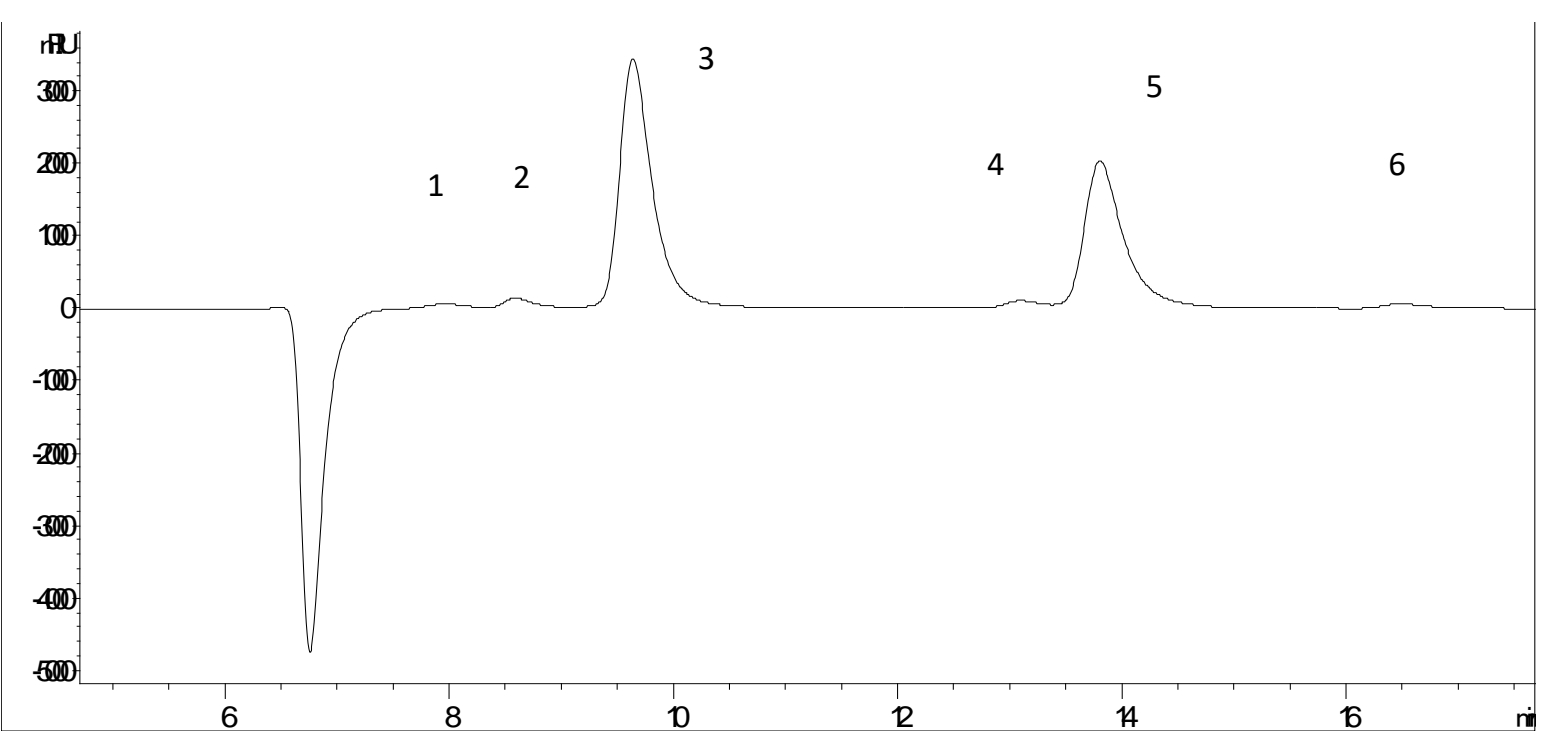

Fig. 49. Cromatograma de muestra de licor del cultivo L/R $10^{7}$ a las $192 \mathrm{~h}$. Los picos corresponden a 1) Ácido oxálico, 3)Glucosa, 4)Ácido succínico, 5)Ácido láctico, 6)Ácido acético. El pico 2 no identificado puede corresponder a ácido cetoglutárico.

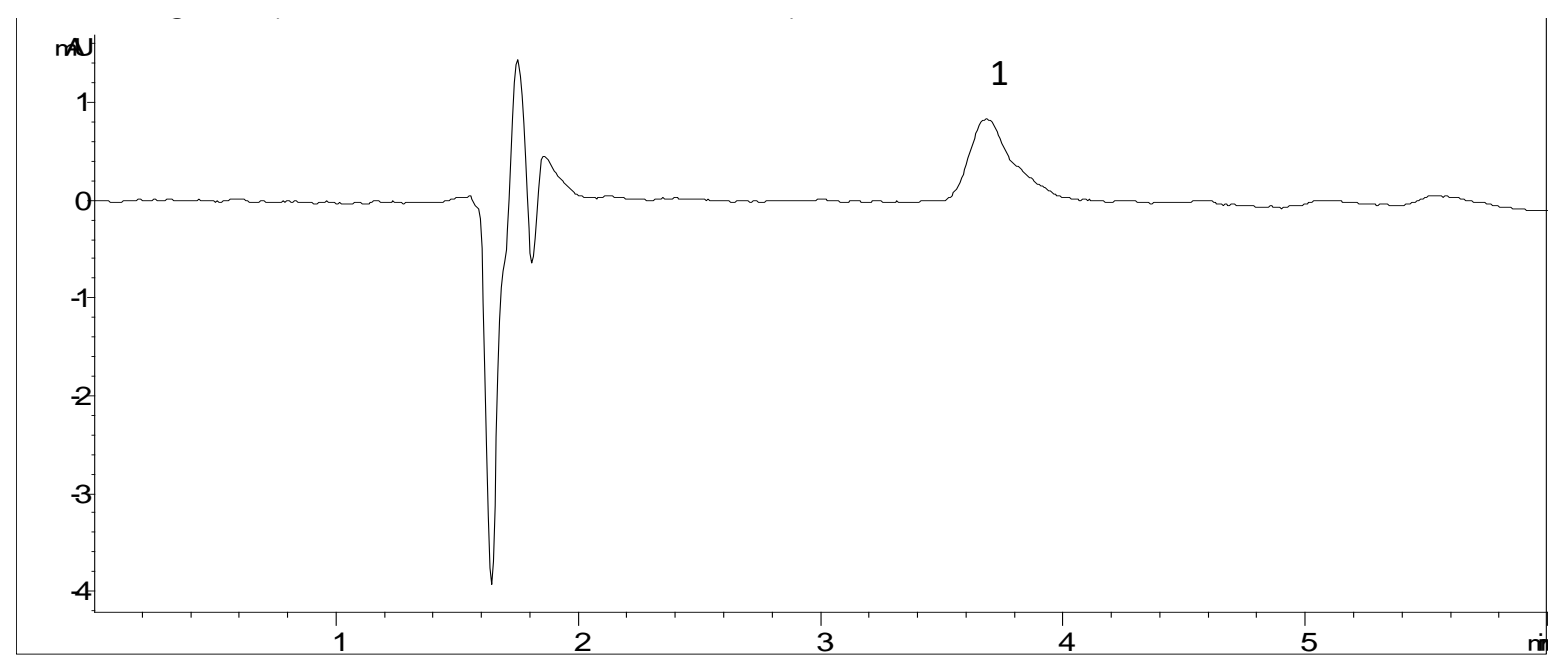

Fig.50. Cromatograma de muestra de astaxantina extraída del licor del cultivo L/R $10^{7}$ a las 192 h. Pico 1 corresponde a trans-astaxantina. 


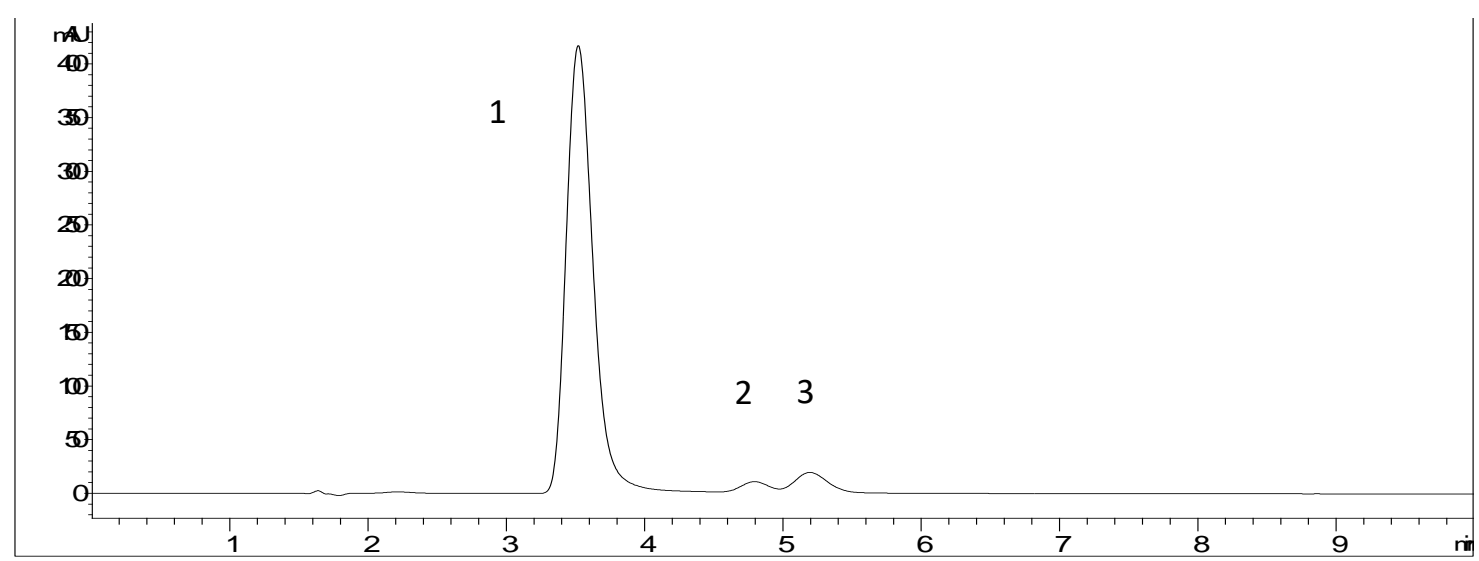

Fig.51. Cromatograma de muestra de astaxantina extraída de la fracción sólida del cultivo L/R $10^{7}$ a las $192 \mathrm{~h}$. Pico 1 corresponde a trans-astaxantina. Picos 2 y 3 corresponden a 9cis y 13 -cis astaxantina, respectivamente. 
Anexo III

ESPECTROS DE RMN H ${ }^{1}$

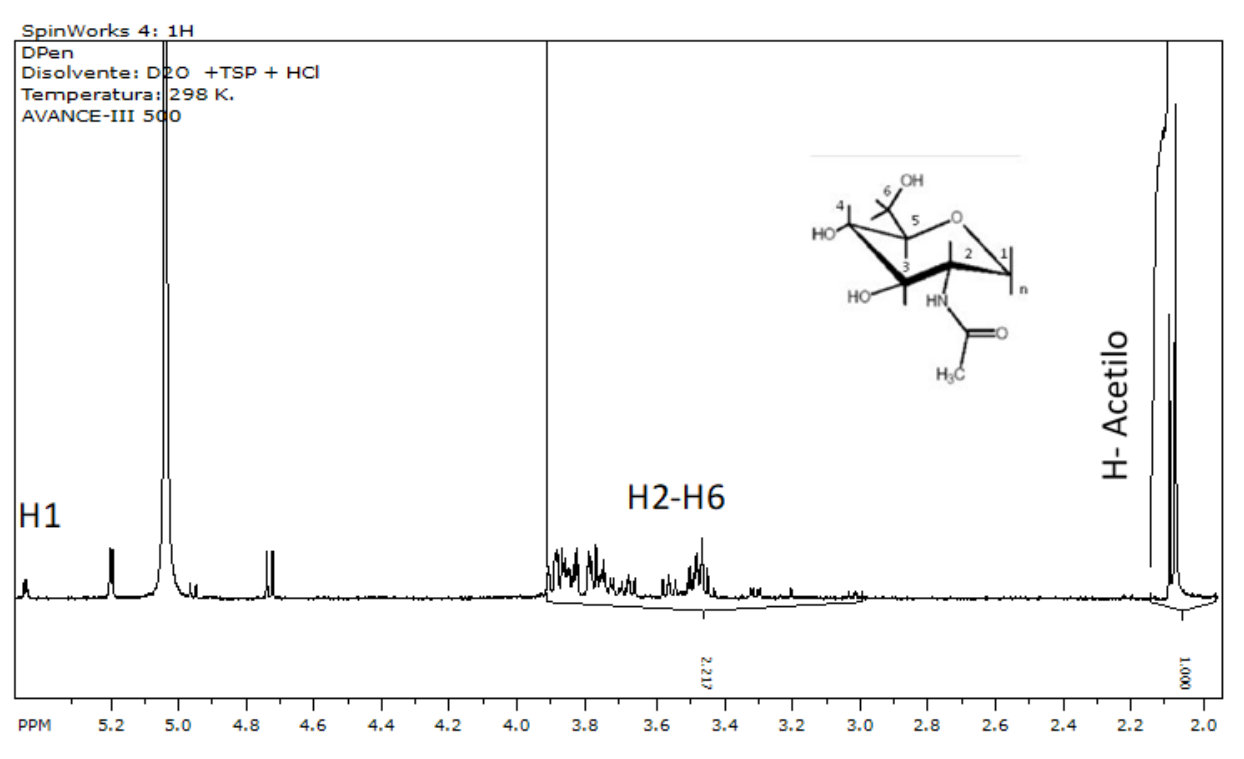

Fig. 52. Espectro de $\mathrm{RMN} \mathrm{H}^{1}$ de la muestra final de quitina obtenida mediante desproteinización enzimática con la enzima comercial Deterzyme ${ }^{\circledR}$. Realizado en $\mathrm{DCl}+\mathrm{D}_{2} \mathrm{O}$ a $25^{\circ} \mathrm{C}(500 \mathrm{MHz})$. Muestra mezclada con $\mathrm{DCl}$ a $50{ }^{\circ} \mathrm{C}$ por $8 \mathrm{~h}$ y diluida en $\mathrm{D}_{2} \mathrm{O}$.

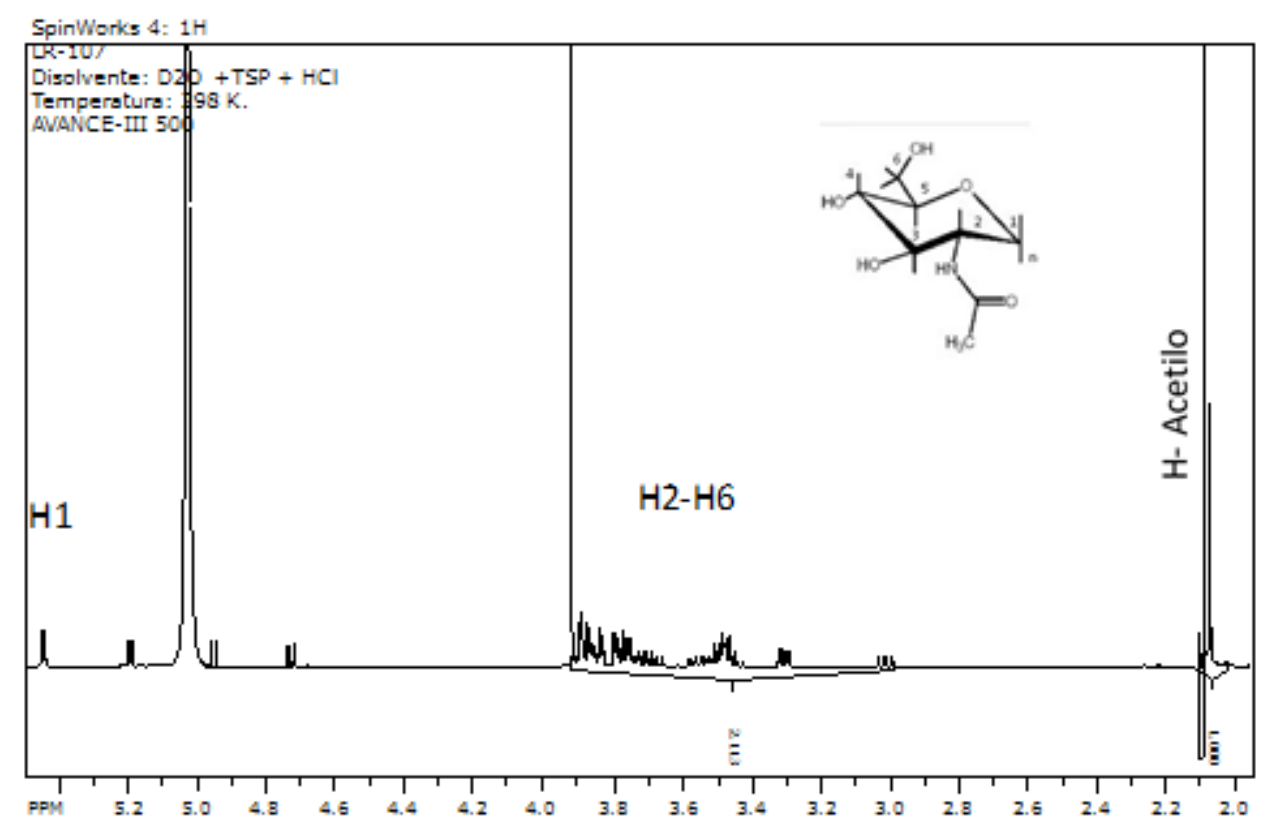

Fig. 53. Espectro de $\mathrm{RMN} \mathrm{H}^{1}$ de la muestra final de quitina obtenida mediante inoculación de $L$ y $R$ en desperdicios de camarón. Realizado en $\mathrm{DCl}+\mathrm{D}_{2} \mathrm{O}$ a $25^{\circ} \mathrm{C}(500 \mathrm{MHz})$. Muestra mezclada con $\mathrm{DCl}$ a $50^{\circ} \mathrm{C}$ por $8 \mathrm{~h}$ y diluida en $\mathrm{D}_{2} \mathrm{O}$. 


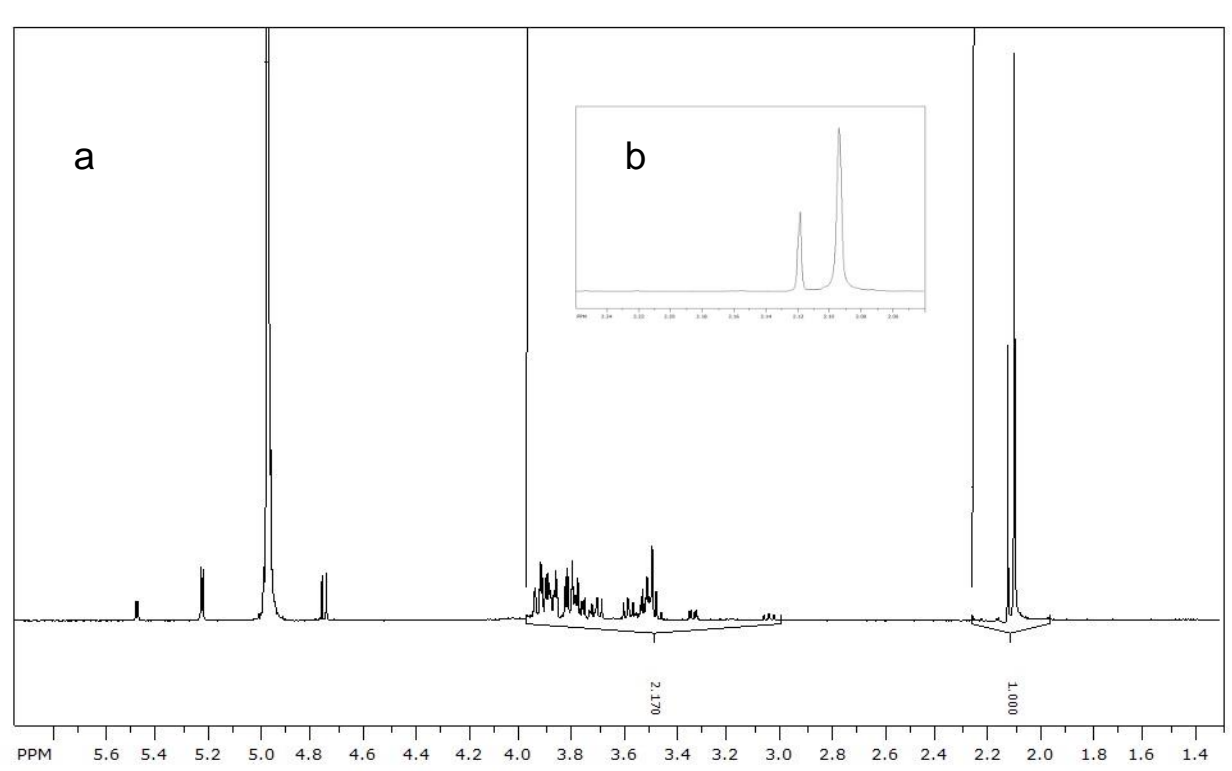

ANEXOS

Fig. 54. Espectro de $\mathrm{RMN} \mathrm{H}^{1}$ de a) Quitina $\mathrm{L}$ diluida en $\mathrm{DCl}+\mathrm{D}_{2} \mathrm{O}$ a $25^{\circ} \mathrm{C}(500 \mathrm{MHz})$. Muestra mezclada con $\mathrm{DCl}$ a $50{ }^{\circ} \mathrm{C}$ por $8 \mathrm{~h}$ y diluida en $\mathrm{D}_{2} \mathrm{O}$. b)Acercamiento H-Acetilo.

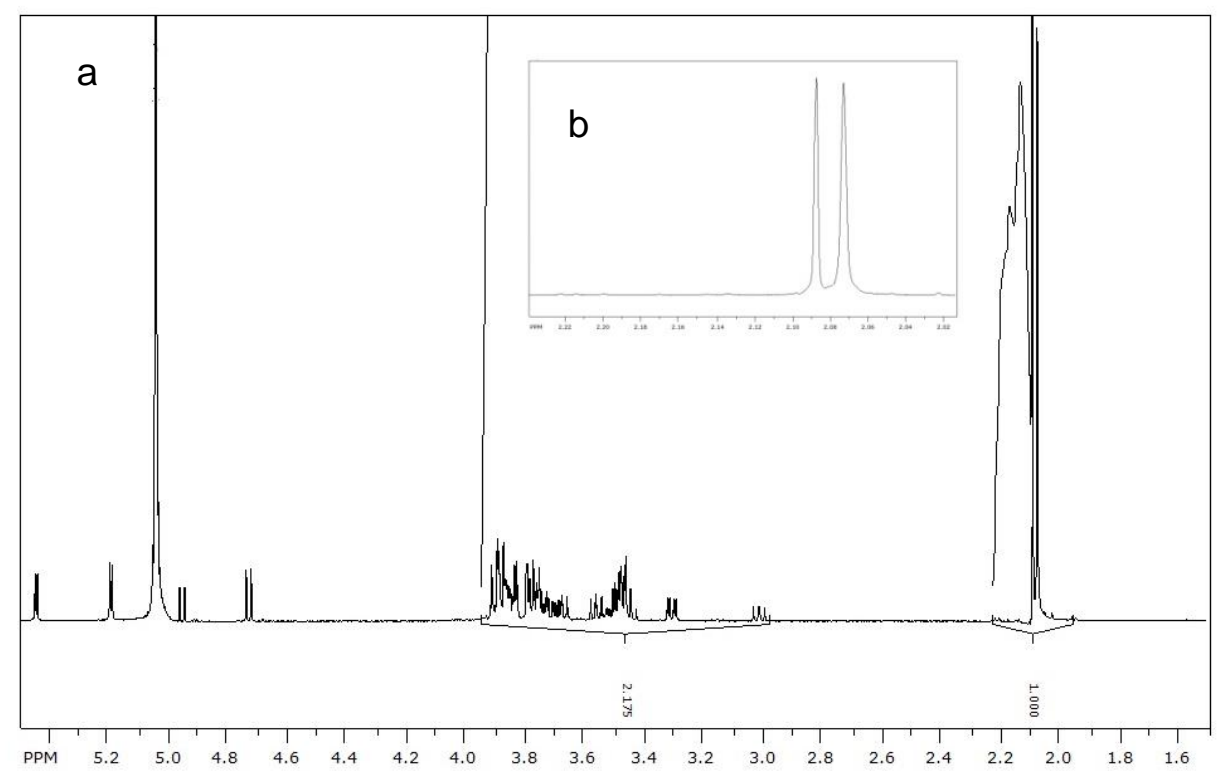

Fig. 55. Espectro de $\mathrm{RMN} \mathrm{H}^{1}$ de a) Quitina $\mathrm{L}$ blanqueada diluida en $\mathrm{DCl}+\mathrm{D}_{2} \mathrm{O}$ a $25^{\circ} \mathrm{C}(500$ $\mathrm{MHz}$ ). Muestra mezclada con $\mathrm{DCl}$ a $50{ }^{\circ} \mathrm{C}$ por $8 \mathrm{~h}$ y diluida en $\mathrm{D}_{2} \mathrm{O}$. b)Acercamiento $\mathrm{H}$ Acetilo. 


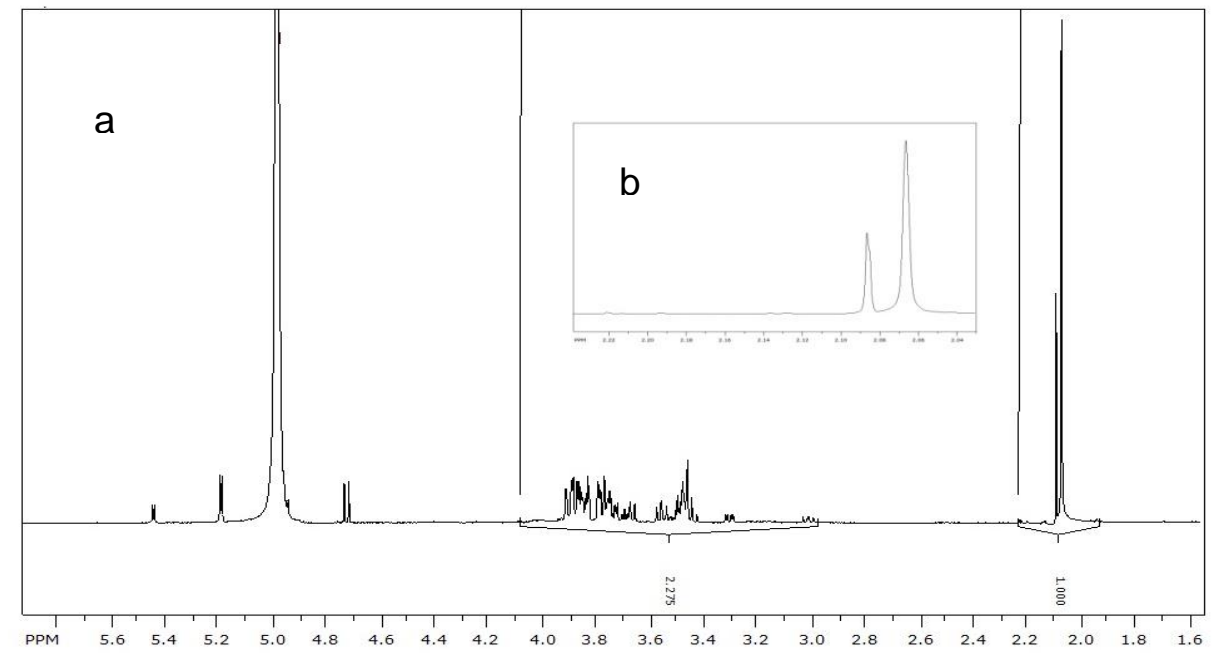

INEXOS

Fig. 56. Espectro de $\mathrm{RMN} \mathrm{H} \mathrm{H}^{1}$ de a) Quitina $\mathrm{LR}$ diluida en $\mathrm{DCl}+\mathrm{D}_{2} \mathrm{O}$ a $25^{\circ} \mathrm{C}(500 \mathrm{MHz})$. Muestra mezclada con $\mathrm{DCl}$ a $50^{\circ} \mathrm{C}$ por $8 \mathrm{~h}$ y diluida en $\mathrm{D}_{2} \mathrm{O}$. b)Acercamiento H-Acetilo.

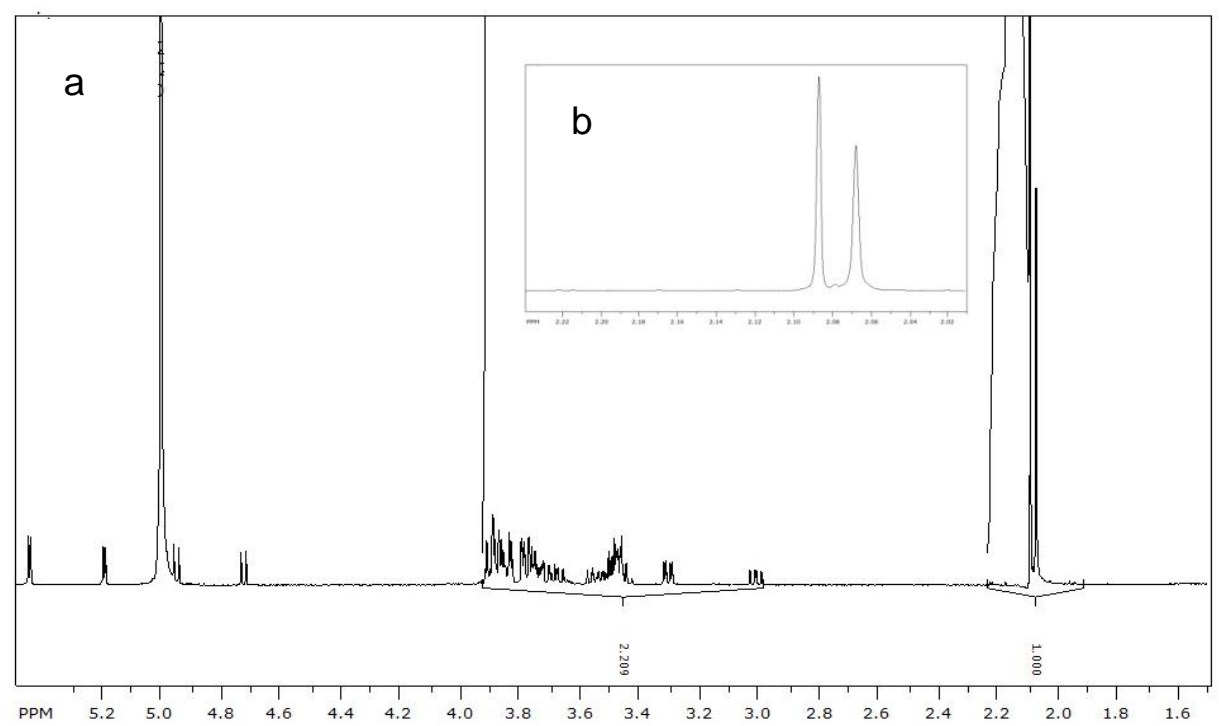

Fig. 57. Espectro de $\mathrm{RMN} \mathrm{H} \mathrm{H}^{1}$ de a) Quitina $\mathrm{LR}$ blanqueada diluida en $\mathrm{DCl}+\mathrm{D}_{2} \mathrm{O}$ a $25^{\circ} \mathrm{C}(500$ $\mathrm{MHz}$ ). Muestra mezclada con $\mathrm{DCl}$ a $50{ }^{\circ} \mathrm{C}$ por $8 \mathrm{~h}$ y diluida en $\mathrm{D}_{2} \mathrm{O}$. b)Acercamiento $\mathrm{H}$ Acetilo. 


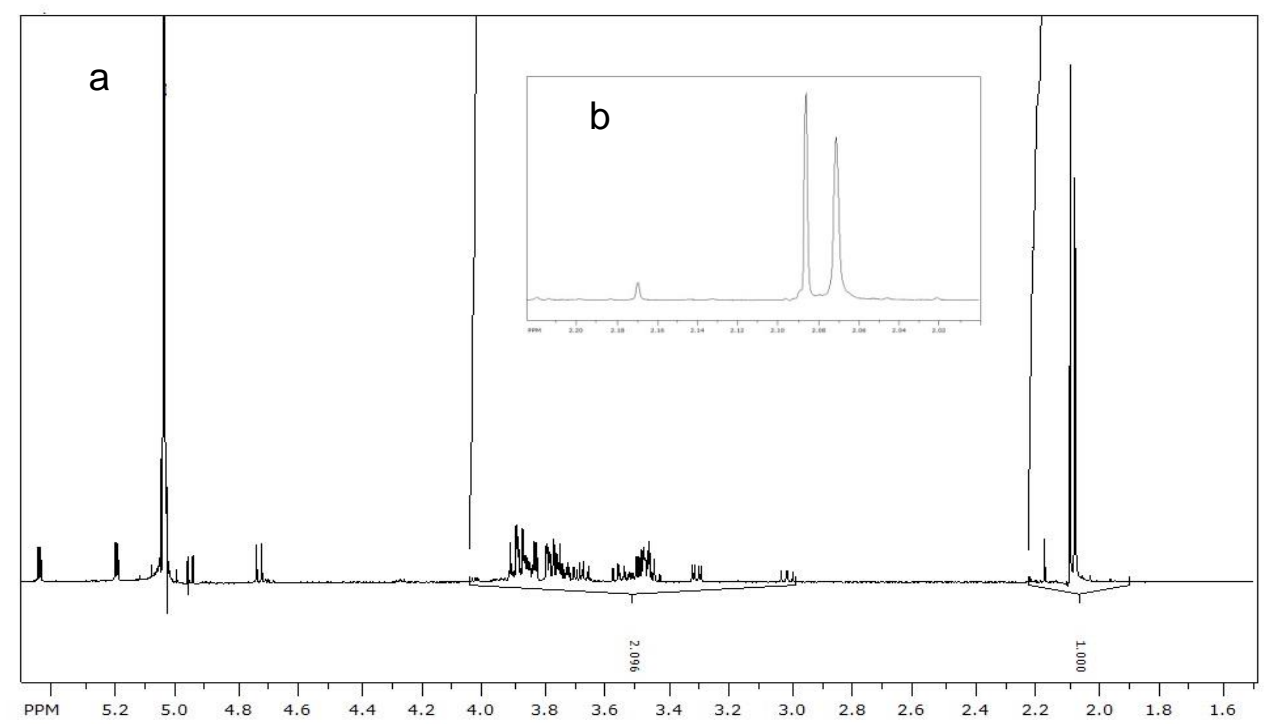

Fig. 58. Espectro de $\mathrm{RMN} \mathrm{H}^{1}$ de a) Quitina comercial diluida en $\mathrm{DCl}+\mathrm{D}_{2} \mathrm{O}$ a $25^{\circ} \mathrm{C}(500 \mathrm{MHz})$. Muestra mezclada con $\mathrm{DCl}$ a $50{ }^{\circ} \mathrm{C}$ por $8 \mathrm{~h}$ y diluida en $\mathrm{D}_{2} \mathrm{O}$. b)Acercamiento H-Acetilo. 


\section{Anexo IV \\ PATRÓN DE DIFRACCIÓN DE RAYOS $X$}

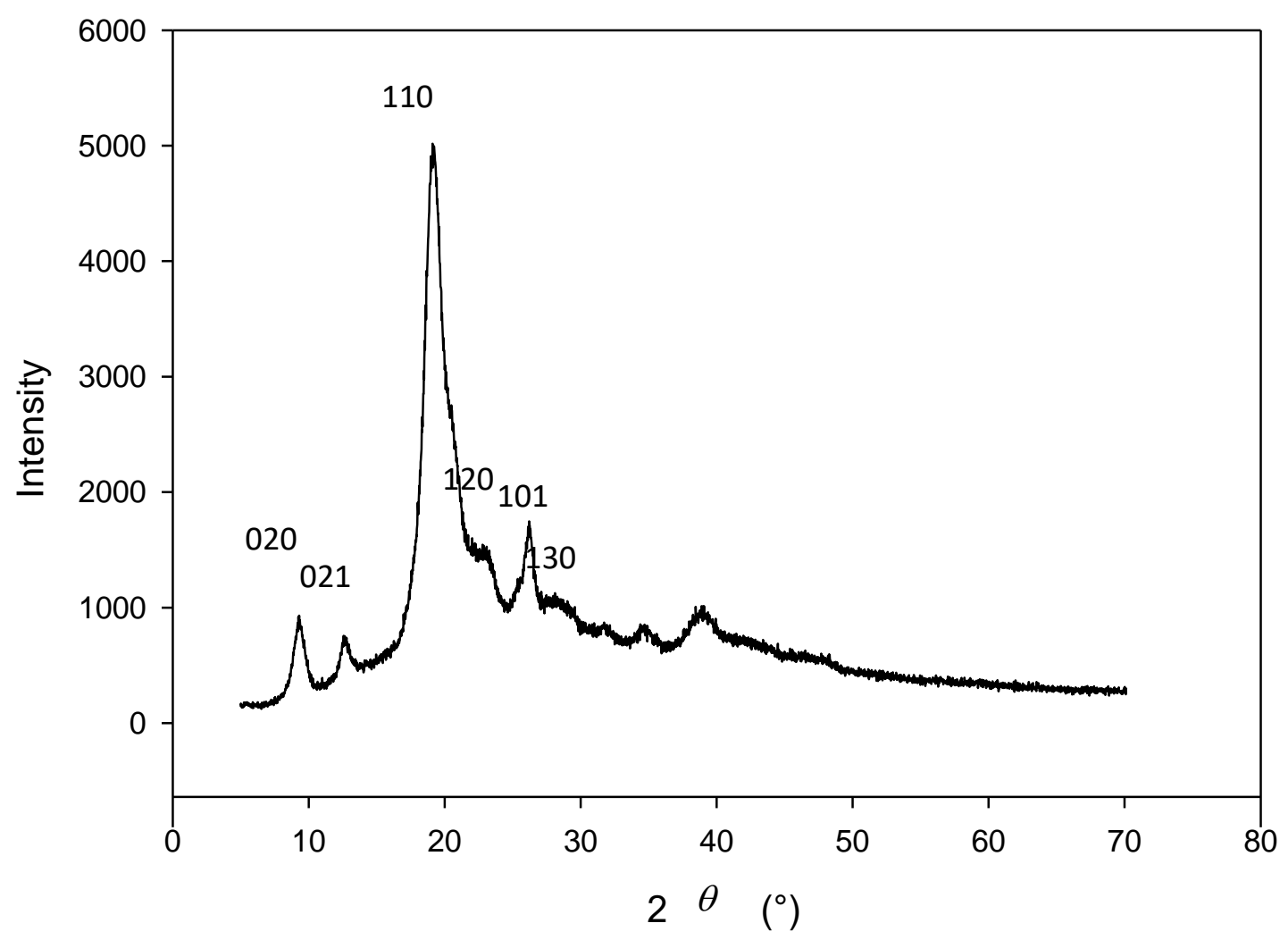

Figura 59. Patrón de difracción de rayos x a $\lambda=1.5418 \mathrm{~A}$ en $2 \theta=4.5-70^{\circ} \mathrm{C}$ cada $0.02^{\circ}$ de quitina desmineralizada del cultivo L/R $10^{7}$ a las $192 \mathrm{~h}$. 
OBTENCION Y CARACTERIZACION DE NANOFIBRILLAS DE QUTTINA

EXTRAIDA POR MÉTODOS

BIOLÓGICOS Y SU

DESACETILACIÓN A QUITOSANO

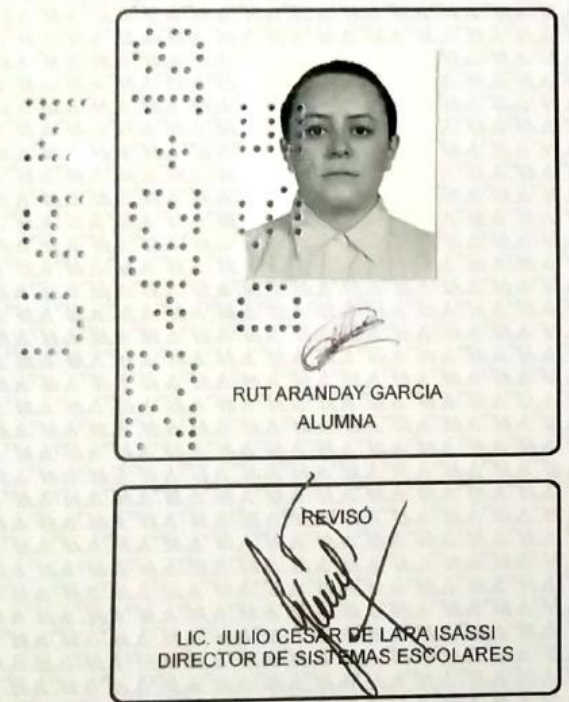

Bajo la Presidencia de la primera y con caracter de Bajo la Presidencia de la printón de la Disertacion publica, curaren, para la obtención del grado de:

DOCTORA EN BIOTECNOLOGIA

DE: RUT ARANDAY GARCIA

y de acuerdo con el articulo 78 fracción IV del Reglamento Universidad Autónoma Metropolitana, los miembros del jurado resolvieron:

\section{Aprobar}

Acto continuo, la presidenta del jurado comunico a la interesada el resultado de la evaluación $y$, en caso aprobatorio, le fue tomada la protesta.

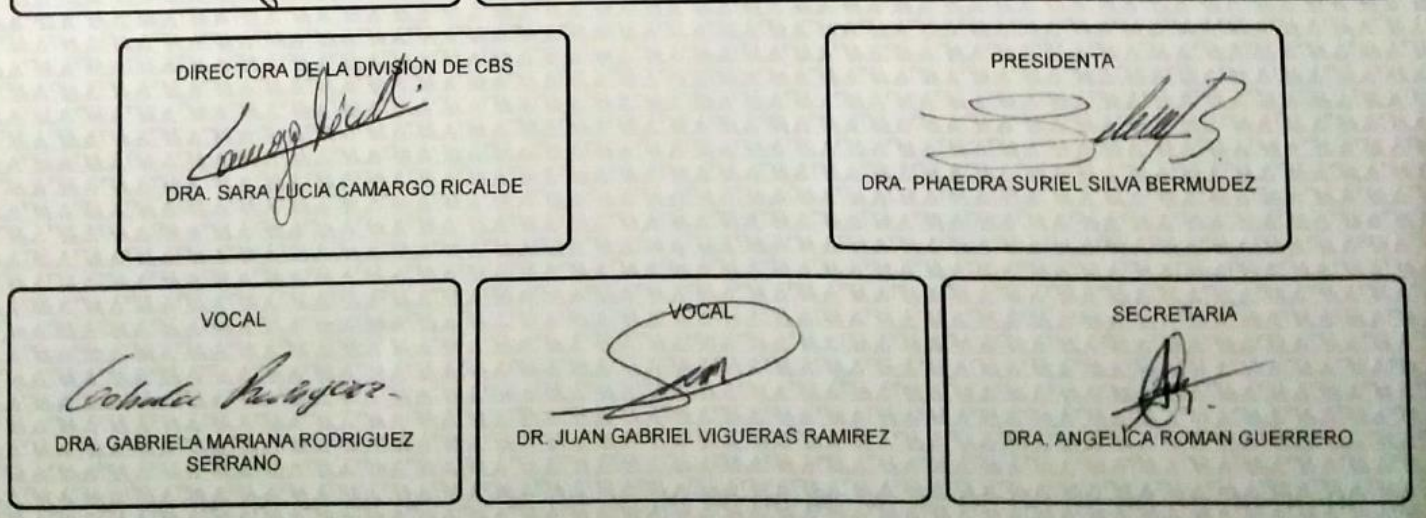

